UNIVERZITET U BEOGRADU

BIOLOŠKI FAKULTET

Katarina Zeljić

POVEZANOST POLIMORFIZAMA VDR, CYP27B1 I

CYP24A1 GENA SA ETIOLOŠKIM FAKTORIMA I

ISHODOM BOLESTI KOD PACIJENATA SA

ORALNIM SKVAMOCELULARNIM KARCINOMOM

Doktorska disertacija

Beograd, 2012. 
UNIVERSITY OF BELGRADE

FACULTY OF BIOLOGY

Katarina Zeljić

\section{ASSOCIATION OF POLYMORPHISMS IN}

VDR, CYP27B1 AND CYP24A1 GENES

WITH ETIOLOGICAL FACTORS AND DISEASE

OUTCOMES IN PATIENTS WITH ORAL

SQUAMOUS CELL CARCINOMA

Doctoral dissertation

Belgrade, 2012. 


\section{PODACI O MENTORIMA I ČLANOVIMA KOMISIJE}

\section{MENTORI}

\section{Dr Marina Stamenković-Radak}

Vanredni profesor Biološkog fakulteta Univerziteta u Beogradu

Dr sci. med. Zvonko Magić

Redovni profesor Medicinskog fakulteta Vojnomedicinske akademije Univerziteta Odbrane u Beogradu

\section{ČLAN KOMISIJE}

\section{Dr Jelena Milašin}

Redovni profesor Stomatološkog fakulteta Univerziteta u Beogradu 


\section{$Z \mathcal{A H} \mathcal{H} \mathcal{A} \mathcal{L} I C \mathcal{A}$}

Najsrdačnije se zahvaljujem svojim profesorima i mentorima prof. $d r$ Marini Stamenković-Radak i prof. dr sci. med. Zvonku Magiću na ukazanom poverenju i pruženoj pomoći u toku studija i izrade doktorske disertacije.

Iskrenu zahvalnost dugujem prof. dr Jeleni Milašin za predusretljivost i dobru saradnju i $d r$ biol. sci. Gordani Šupić za maksimalnu pomoć i podršku tokom realizacije i pisanja doktorske disertacije.

Kolegama i članovima laboratorije $d r$ biol. sci. Bojani Cikota-Aleksić, mr Nataši Strelić, spec. biol. Vesni Ilić, mr Aleksandri Petković-Ćurčin i dipl. biohemičaru Stevi Jovandiću na saradnji, korisnim savetima i lepom vremenu provedenom u laboratoriji.

Kolegama sa Katedre za genetiku i evoluciju, a posebno Mariji Savić Veselinović, Mariji Tanasković, Ljupki Filipović i Mihailu Jeliću, za kolegijalnost, profesionalne sugestije i dobro druženje.

Mojim prvim učiteljima biologije Olgi Bogdanović i mr Slobodanki Bobi Milanović, jer su u značajnoj meri doprinele mom profesionalnom opredeljenju.

Neizmerno hvala Mihajlu Farkiću na velikoj podršci i razumevanju, uvek i u svemu.

Svim svojim prijateljima, jer me je druženje sa njima uveseljavalo i činilo dobro raspoloženom.

Mojim Zeljićima i Kojićima na dobroj genetičkoj osnovi.

Mojoj inspiraciji i snazi, vama koji ste me naučili pravim vrednostima u životu i omogućili mi da svoja maštanja danas živim. Mojim najdražima: Ivani, mami i tati.

Ovaj doktorat posvećujem vama i našoj Hani.

Srdačno,

Katarina Zeljić 
„To što znamo je kapljica, to što ne znamo je more".

Isak Njutn 


\section{Povezanost polimorfizama VDR, CYP27B1 i CYP24A1 gena sa etiološkim faktorima $i$ ishodom bolesti kod pacijenata sa oralnim skvamocelularnim karcinomom}

\section{Rezime}

Uvod. Oralni skvamocelularni karcinomi (ㅁal Squamous Cell Carcinoma- OSCC) se karakterišu visokom stopom mortaliteta, lošom prognozom i porastom incidence među osobama mlađe populacije. I pored uloženih napora na polju prevencije, petogodišnje preživljavanje je ostalo nepromenjeno poslednjih nekoliko decenija, što nameće potrebu za nove, molekularne vidove karakterizacije oralnog karcinoma. Poznati faktori rizika za nastanak oralnog karcinoma su: pušenje i žvakanje duvana, konzumiranja alkohola, loša oralna higijena i infekcije visokorizičnim tipovima humanog papiloma virusa. Činjenica da samo izvesni procenat osoba izloženih navedenim faktorima rizika zaista i razvije OSCC, ukazuje na značaj genetičke osnove u procesu oralne kancerogeneze.

Mnogobrojnim studijama je pokazano da vitamin D ima antikancerogeni efekat, koji se ogleda u zaustavljanju ćelijskog ciklusa, inicijaciji ćelijske diferencijacije, indukciji apoptoze, sprečavanju invazije malignih ćelija i antiangiogenetskom dejstvu. Vitamin D ispoljava svoju fiziološki aktivnu ulogu nakon vezivanja za receptor za vitamin D (engl. Vitamin D Receptor- VDR) koji je kodiran VDR genom. U VDR genu je identifikovan veliki broj polimorfizama nukleotidne sekvence (engl. Single Nucleotide Polymorphisms- SNP), od kojih samo mali broj ima funkcionalni efekat. U metabolizam vitamina D su uključeni članovi velike familije proteina citohroma P450 i to: $1 \alpha$-hidroksilaza uključena u proces anabolizma (kodirana CYP27B1 genom), odnosno 24-hidroksilaza koja ima ulogu u katabolizmu (kodirana CYP24A1 genom). Obzirom na značaj proučavanja SNP-ova u genetičkim studijama asocijacije, postavlja se pitanje da li postojanje izvesnih genetičkih varijanti u genima uključenim u funkcionisanje i metabolizam vitamina D može biti asocirano sa rizikom nastanka oralnog karcinoma, kliničko patološkim karakteristikama i preživljavanjem pacijenata. 
Cilj. Cilj ove doktorske disertacije je bilo utvrđivanje postojanja asocijacije između polimorfizama EcoRV, FokI, TaqI, ApaI, BsmI i rs11574085 u VDR genu, rs4646536 u CYP27B1 i rs2296241 polimorfizma u CYP24A1 genu sa rizikom za nastanak oralnog karcinoma, etiološkim faktorima i ukupnim preživljavanjem pacijenata. Pored navedenog, cilj je bilo i utvrđivanje postojanja haplotipskih blokova $u$ studijskoj grupi i asocijacije između registrovanih haplotipova sa rizikom za nastanak oralnog karcinoma i preživljavanjem.

Materijal i metode. Studijska grupa je obuhvatala 110 pacijenata sa dijagnostikovanim oralnim skvamocelularnim karcinomom i 122 zdrave osobe kontrolne grupe odgovarajuće polne i starosne distribucije. DNK je izolovana iz uzoraka primarnih tumora u grupi pacijenata i periferne krvi kontrolne grupe. Genotipovi analiziranih polimorfizama su određivani PCR-RFLP metodom u slučaju VDR EcoRV, FokI, TaqI i ApaI polimorfizama, odnosno Real Time PCR metodom za rs11574085 polimorfizam u VDR genu i polimorfizme u CYP27B1 i CYP24A1 genima. Dobijeni rezultati su obrađeni statističkim programom SPSS. Vrednosti neravnoteže vezanosti kao i učestalosti haplotipova su računate pomoću programa Haploview, dok je programom Thesias analizirana povezanost između registrovanih haplotipova i preživljavanja. Asocijacije su smatrane statistički značajnim ukoliko je p vrednost bila manja od 0.05 .

Rezultati. Zabeležene su značajne razlike $\mathrm{u}$ distribuciji genotipova VDR polimorfizama EcoRV ( $p=0.019, \chi^{2}$ test), ApaI ( $p=0.013, \chi^{2}$ test) i BsmI ( $p=0.025, \chi^{2}$ test), kao i CYP24A1 rs2296241 polimorfizma ( $p=0.025$, Fisher test) između OSCC i kontrolne grupe. Statistički značajna razlika u distribuciji alela je zabeležena u slučaju EcoRV ( $p=0.019, \chi^{2}$ test) i ApaI polimorfizma ( $p=0.019, \chi^{2}$ test). Asocijacija sa polom je zabeležena za VDR TaqI ( $p=0.006, \chi^{2}$ test), BsmI ( $p=0.002, \chi^{2}$ test) i CYP27B1 rs4646536 ( $\mathrm{p}=0.014, \chi^{2}$ test), dok je značajna veza uočena između godina i ApaI SNP-a ( $p=0.049, \chi^{2}$ test). Pušenje je bilo u asocijaciji sa TaqI polimorfizmom $\left(\mathrm{p}=0.039, \chi^{2}\right.$ test), dok je analizirani SNP u CYP27B1 genu bio asociran sa konzumacijom alkohola ( $\mathrm{p}=0.012, \chi^{2}$ test). Kada je reč o kliničko patološkim 
odlikama bolesti, zabeleženo je postojanje statistički značajne veze između TaqI polimorfizma i recidiva bolesti ( $\mathrm{p}=0.008, \chi^{2}$ test).

Uočeno je statistički značajno smanjenje rizika za razvoj oralnog karcinoma kod heterozigota AG analiziranog polimorfizma CYP24A1 gena, u odnosu na divlji AA genotip (OR=0.281, $\mathrm{p}=0.000)$.

Pacijenti FokI ff genotipa su imali lošije preživljavanje $(p=0.012$, log-rank test) u poređenju sa heterozigotnim i mutiranim genotipom zajedno. Stratifikovana analiza prema nodalnom statusu i stadijumu tumora je pokazala da je ff genotip asociran sa lošijim preživljavanjem u grupi sa negativnim i pozitivnim nodalnim statusom (redom: $\mathrm{p}=0.025, \mathrm{p}=0.040$, log-rank test) $\mathrm{i} u$ III stadijumu tumora ( $p=0.026$, log-rank test). Multivarijantna Cox-regresiona analiza je pokazala da se VDR FokI polimorfizam može koristiti kao nezavisni prognostički faktor.

Zaključak. Analiza polimorfizama gena uključenih u funkcionisanje i metabolizam vitamina D može dati važne informacije o razvoju i progresiji oralnog karcinoma. Polimorfizam u CYP24A1 genu je značajno asociran sa sniženim rizikom za razvoj oralnog karcinoma, što je najverovatnije rezultat njegovog funkcionalnog efekta ili neravnoteže vezanosti sa drugim polimorfizmima unutar CYP24A1 gena ili čak sa polimorfizmima blisko lociranih susednih gena. Pored toga, ovakav nalaz bi mogao ukazati na potencijalno korišćenje datog polimorfizma CYP24A1 gena $u$ prediktivne svrhe. VDR FokI polimorfizam može biti razmatran kao potencijalni molekularni marker za preživljavanje, to jest može se koristiti kao nezavisni prognostički indikator. Ovakav nalaz je najverovatnije posledica postojanja funkcionalnog efekta FokI polimorfizma.

Ključne reči. Oralni skvamocelularni karcinom, polimorfizmi nukleotidne sekvence, VDR gen, CYP27B1 gen, CYP24A1 gen.

Naučna oblast: Biologija

Uža naučna oblast: Genetika

UDK: 575.22: [575.113:577.161.2]]:616-006.6 (043.3) 


\title{
Association of polymorphisms in VDR, CYP27B1 and CYP24A1 genes with etiological factors and disease outcomes in patients with oral squamous cell carcinoma
}

\begin{abstract}
Introduction. $\underline{\text { Oral }} \underline{\mathrm{S} q u a m o u s} \underline{\text { Cell }}$ Carcinoma (OSCC) is characterized with a high mortality, low survival rate and rising incidences among members of younger age groups. Despite efforts in prevention, the survival rate remains unchanged for the last few decades, which indicates the need for oral cancer molecular characterization. The well-known risk factors are tobacco smoking and chewing, alcohol consumption, poor oral hygiene and infection with high risk human papilloma virus types. The fact that only a small percentage of people exposed to the risk factors really develops OSCC indicates the importance of genetic background in the process of oral cancerogenesis.

Numerous studies have demonstrated the anticancerogen effects of vitamin D, which is reflected in cell cycle arrest, induction of cell differentiation, apoptosis induction, inhibition of malignant cell invasion and antiangiogenic effect. Vitamin D exerts it's physiological function after binding to the Vitamin $\underline{D}$ Receptor (VDR),

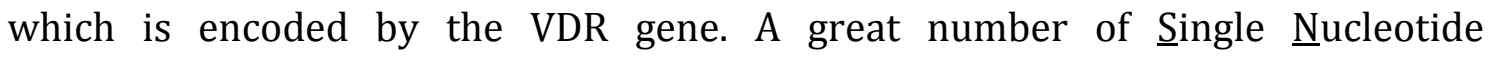
Polymorphisms (SNPs) have been identified in the VDR gene, among which a small number have functional effects. Members of the huge protein cytochrome P450 family are involved in vitamin D metabolism: $1 \alpha$-hydroxylase is involved in anabolism (encoded by the CYP27B1 gene) and 24-hydroxylase is involved in catabolism (encoded by the CYP24A1 gene). Since SNPs investigation is of great importance in the genetic association studies, it is interesting to consider whether genetic variants in genes, involved in vitamin D functioning and metabolism, could be associated with oral cancer risk, clinicopathological characteristics and patient survival.
\end{abstract}


Aim. The aim of the doctoral dissertation was to determine the association between polymorphisms EcoRV, FokI, TaqI, ApaI, BsmI and rs11574085 in VDR gene, rs4646536 in CYP27B1 and rs2296241 polymorphisms in CYP24A1 gene with oral cancer risk, etiological factors and overall patients' survival. Besides that, the aim was to determine the existence of haplotype blocks in the study group and to determine the association between detected haplotypes with risk of oral cancer development and survival.

Material and methods. The study group consisted of 110 patients with diagnosed oral squamous cell carcinoma and 122 healthy individuals in the control group, matched in gender and age. DNA was isolated from the tumour tissue samples in the patients group and from peripheral blood samples, in the control group. VDR gene polymorphisms EcoRV, FokI, TaqI and ApaI were determined using the PCRRFLP method and PCR Real Time method in the case of rs11574085 in VDR and polymorphisms in CYP27B1 and CYP24A1 genes. Obtained results were analysed by the statistical program SPSS. Linkage disequilibrium values as well as haplotype frequencies were calculated using the Haploview program, while association between detected haplotypes and survival were performed by the program Thesias. Associations were considered as significant when $\mathrm{p}$ values were less than 0.05 .

Results. The statistically significant differences in the frequencies of the VDR genotypes were observed between the OSCC and control group for the EcoRV $\left(p=0.019, \chi^{2}\right.$ test $)$, ApaI $\left(p=0.013, \chi^{2}\right.$ test $)$ and BsmI $\left(p=0.025, \chi^{2}\right.$ test $)$ polymorphisms, as well for CYP24A1 rs2296241 polymorphism ( $\mathrm{p}=0.025$, Fisher test). The statistically significant differences in the allele distribution was noticed for the EcoRV ( $p=0.019, \chi^{2}$ test) and ApaI polymorphism ( $p=0.019, \chi^{2}$ test). The association with gender was observed for $\operatorname{VDR}$ TaqI $\left(\mathrm{p}=0.006, \chi^{2}\right.$ test), BsmI $\left(\mathrm{p}=0.002, \chi^{2}\right.$ test) and CYP27B1 rs4646536 ( $\mathrm{p}=0.014, \chi^{2}$ test), while significant association with age was observed for ApaI SNP ( $p=0.049, \chi^{2}$ test). Smoking was associated with TaqI polymorphism ( $\mathrm{p}=0.039, \chi^{2}$ test), while analysed SNP in CYP27B1 gene was associated with alcohol consumption ( $p=0.012, \chi^{2}$ test). In the 
case of clinicopathological variables, statistically significant association was detected between TaqI polymorphism and recurrence $\left(\mathrm{p}=0.008, \chi^{2}\right.$ test).

The statistically significant decrease of oral cancer risk was observed in heterozygote AG of analysed polymorphism in CYP24A1 gene, in comparison with wild type AA genotype (OR=0.281, $\mathrm{p}=0.000)$.

Patients with FokI ff genotype had a lower survival rate $(p=0.012$, log-rank test) compared with heterozygous and mutated genotype combined. A stratified analysis by the lymph node involvement and tumours stage showed that ff genotype is associated with poor survival in groups with and without lymph node involvement $(p=0.025, p=0.040$, respectively, log-rank test $)$ and in stage III tumours ( $\mathrm{p}=0.026$, log-rank test). Multivariate Cox-regression analysis revealed that VDR FokI polymorphism could be considered as an independent prognostic factor.

Conclusions. Analysis of gene polymorphisms involved in vitamin D functioning and metabolism could provide important information on oral cancer development and progression. Polymorphism in CYP24A1 gene was significantly associated with oral cancer development, which could be ca onsequence of its functional effect or linkage disequilibrium with other polymorphisms in CYP24A1 gene or even with polymorphisms in the nearby different genes. Besides, this finding indicates that analysed polymorphism in CYP24A1 gene could be used for predictive purposes. VDR FokI polymorphism could be considered as a potential molecular marker of survival and could be used as an independent prognostic indicator. These findings most probably represent the functional effect of FokI polymorphism.

Keywords: oral squamocellular carcinoma, single nucleotide polymorphisms, VDR gene, CYP27B1 gene, CYP24A1 gene.

Scientific field: Biology

Narrower scientific field: Genetics

UDC: 575.22: [575.113:577.161.2]]:616-006.6 (043.3) 


\section{S A D R ̌̌ A J}

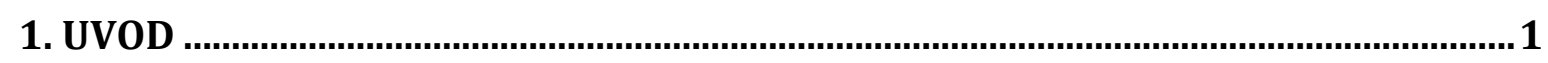

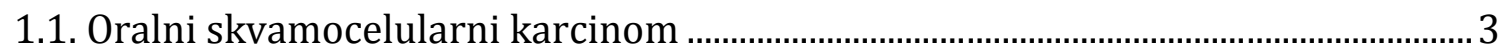

1.1.1. Genetička osnova oralne kancerogeneze ...............................................................

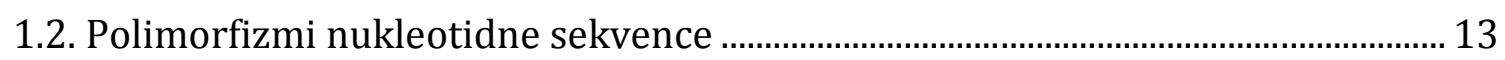

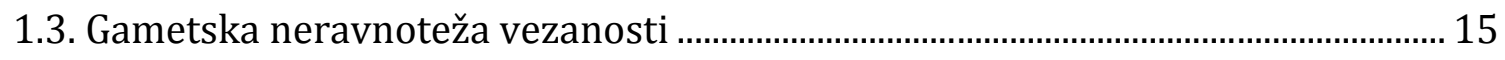

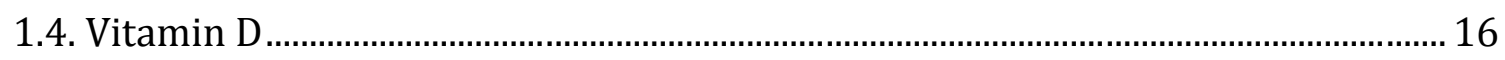

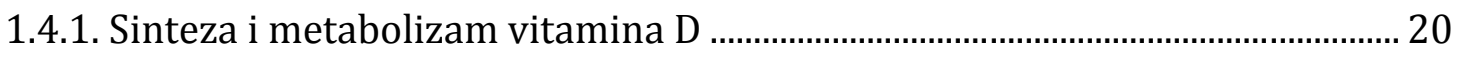

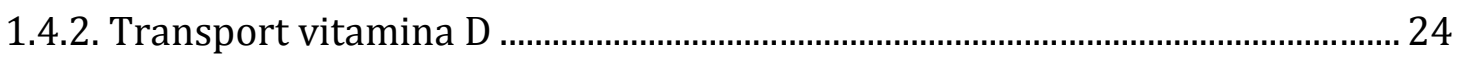

1.4.3. Intracelularni signalni putevi vitamina D .......................................................... 25

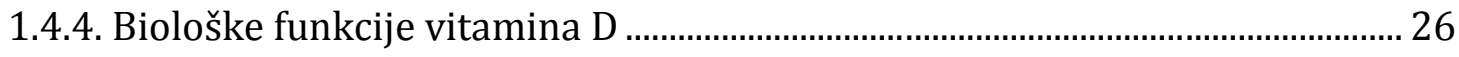

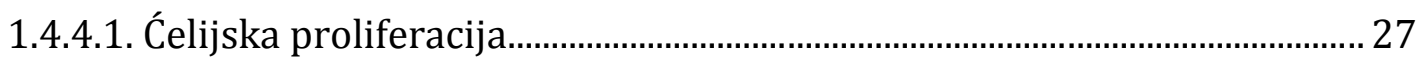

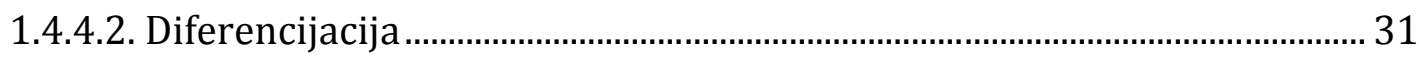

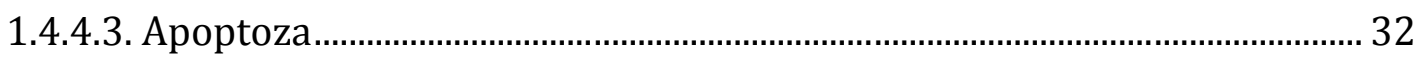

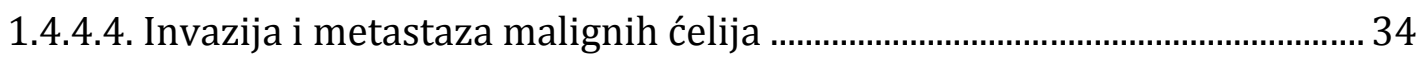

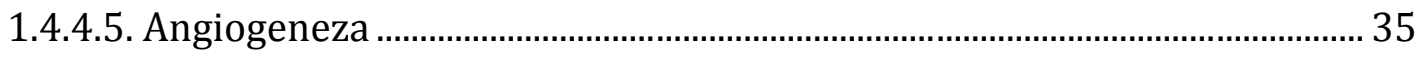

1.4.5. Povezanost geografske širine i vitamina D sa nastankom kancera ................. 36

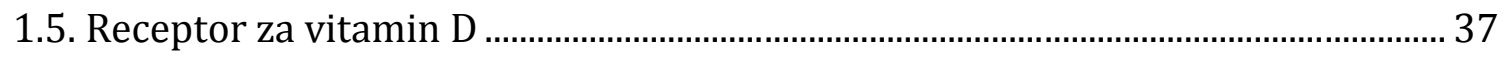

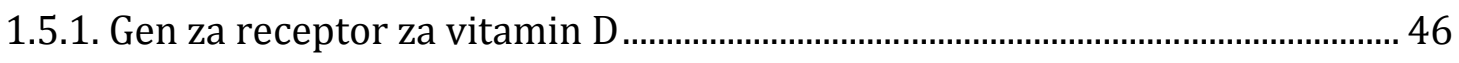

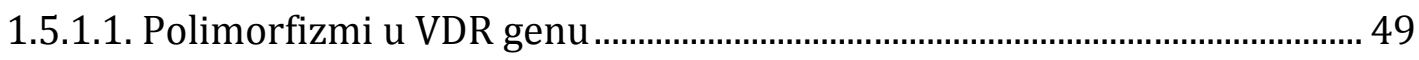

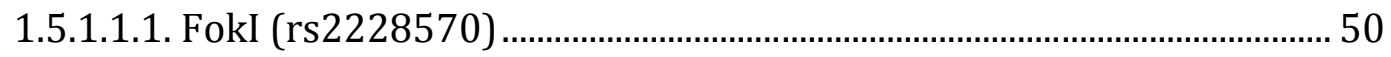

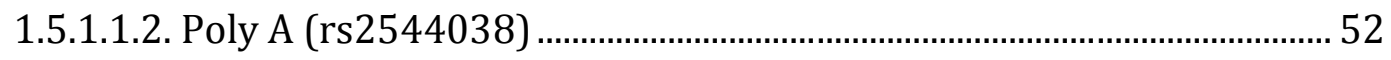

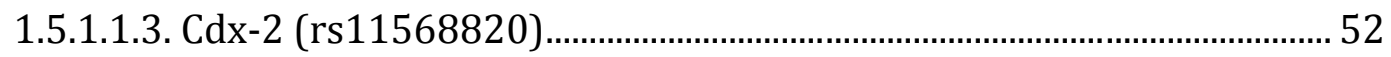

1.5.1.1.4. BsmI (rs1544410)-ApaI (rs7975232)-TaqI (rs731236) .................... 53

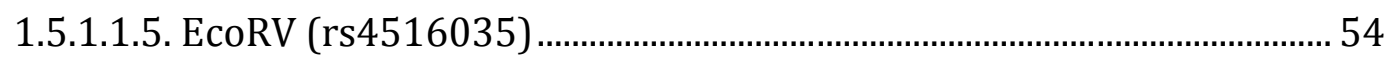

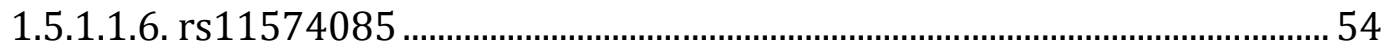

1.5.1.2. Učestalost SNP-ova i haplotipova VDR gena u različitim populacijama55

1.6. Enzim 1 $\alpha$-hidroksilaza i CYP27B1 gen ........................................................................... 57

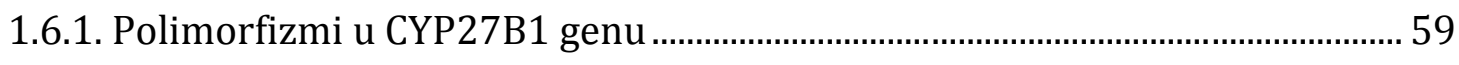

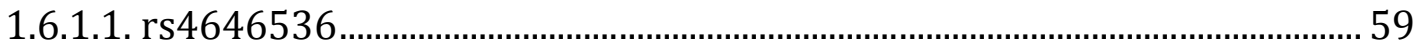




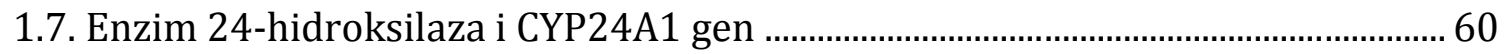

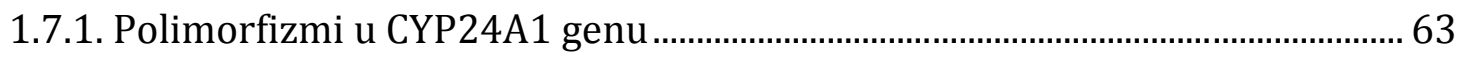

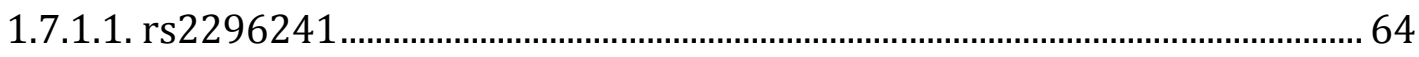

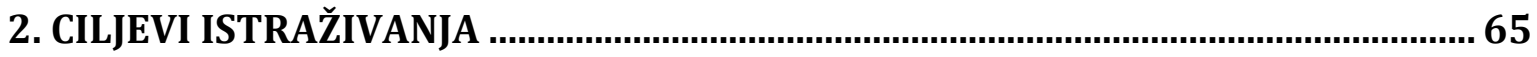

3. MATERIJAL I METODE

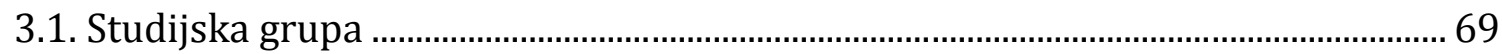

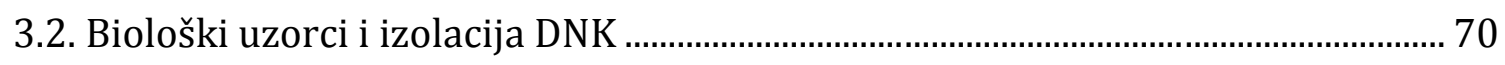

3.3. Provera kvaliteta i koncentracije izolovane DNK …….............................................. 71

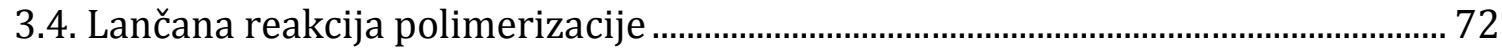

3.5. Analiza polimorfizma dužine restrikcionih fragmenata ........................................... 73

3.6. Real-Time PCR alelska diskriminacija....................................................................... 75

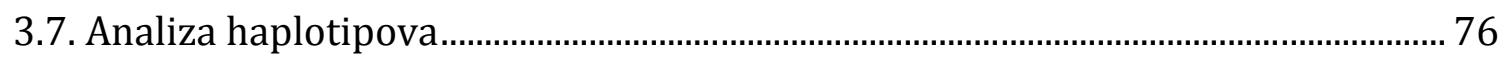

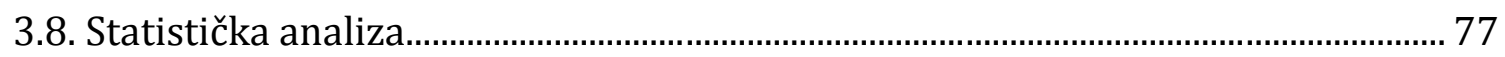

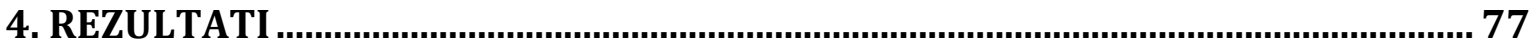

4.1. Analiza polimorfizama u VDR, CYP27B1 i CYP24A1 genima ..................................... 78

4.2. Etiološke i kliničko patološke odlike ispitivane grupe pacijenata ............................ 85

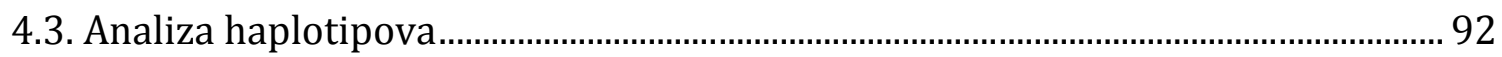

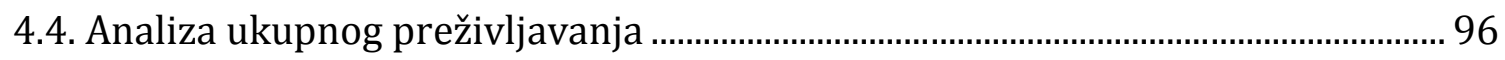

4.5. Analiza promenljivih relevantnih za ukupno preživljavanje .................................102

4.6. Analiza asocijacije haplotipova i preživljavanja..........................................................104

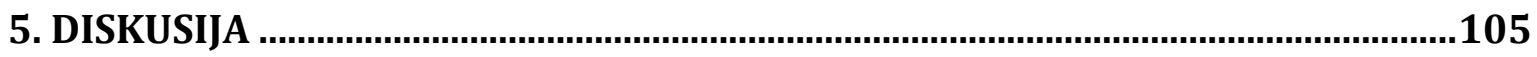

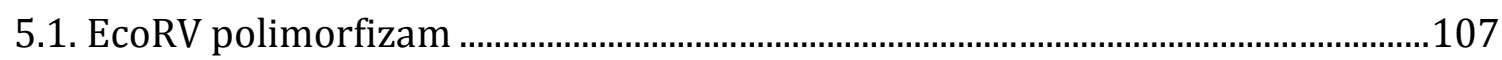

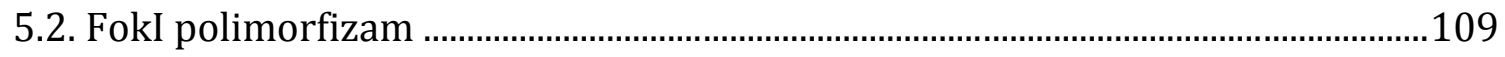

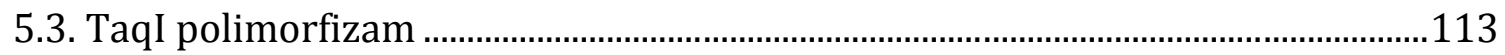

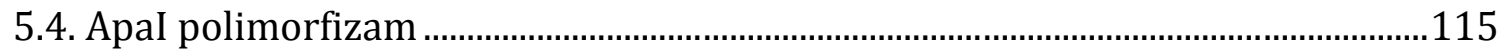

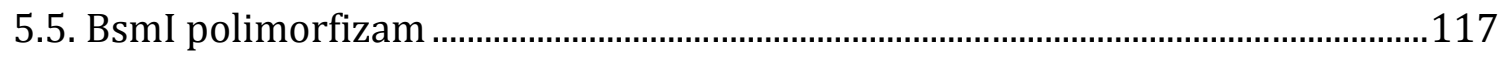

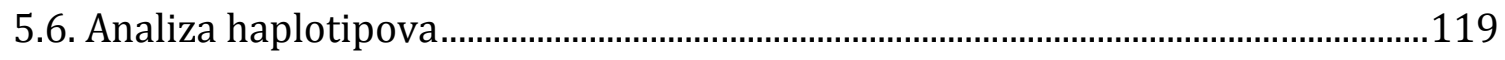

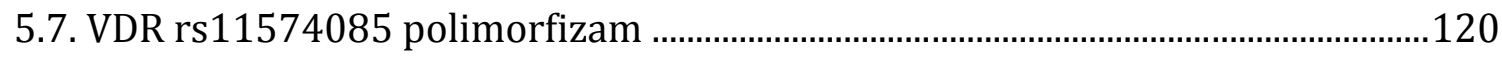

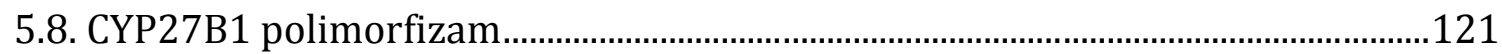

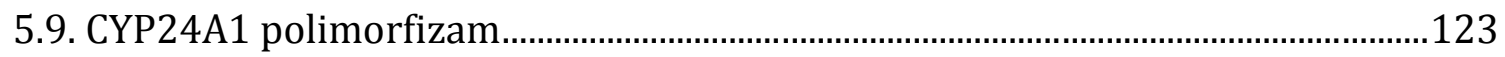

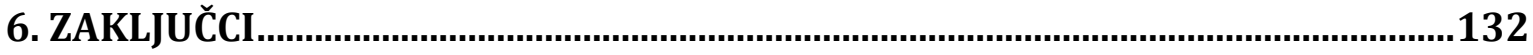

7. LITERATURA 


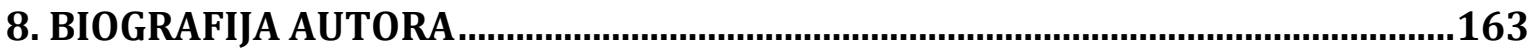

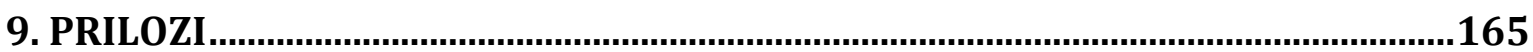


1. UVOD 
Kancer predstavlja vodeći uzročnik smrtnosti svetske populacije nakon kardiovaskularnih bolesti (Global Cancer: Facts and Figures, 2011). Takva statistička slika je odlika ne samo nerazvijenih i zemalja u razvoju, već i visoko razvijenih zemalja, kao što su Sjedinjene Američke Države i brojne Evropske države (Jemal i sar., 2011; Petersen, 2008).

Prema definiciji, kancer predstavlja nekontrolisan rast grupe ćelija, uzrokovane multiplim promenama koje vode narušavanju balansa između proliferacije ćelija i ćelijske smrti (Ruddon, 2007; Schulz, 2007). Karakterišu se nekontrolisanom ćelijskom deobom i rastom, gubitkom kontaktne inhibicije, manjom adhezivnošću i mogućnošću metastaziranja na udaljena mesta $u$ telu (Macdonald i sar., 2004; Rudon, 2007). Prema ustaljenoj literaturnoj klasifikaciji, tumori ili neoplazije (od grčke reči neoplasia-novi rast) se mogu podeliti u dve glavne grupe: benigne i maligne promene. Benigne neoplazije se odlikuju rastom unutar jasno definisane fibrozne kapsule i dobrom diferencijacijom, dok, za razliku od njih, maligne promene invadiraju okolna tkiva, nediferencirane su ili slabo diferencirane (Mcdonald, 2004; Schulz, 2007). U zavisnosti od porekla ćelija od kojih nastaju, maligne neoplazije mogu biti karcinomi (od epitelijalnih ćelija) ili sarkomi (od mezenhimalnih ćelija). Najveći procenat humanih maligniteta se razvija od epitelnog tkiva, pri čemu se karcinomi koji nastaju od pločastog epitela nazivaju skvamocelularni karcinomi, od bazalnog epitela- bazocelularni kacinomi, dok su nastali od žlezdanog epitela poznatiji kao adenokarcinomi (Ruddon, 2007; Schulz, 2007).

Klasifikacija tumora se može vršiti na osnovu više različitih kriterijuma. Moguće je tzv. histološko rangiranje tumora prema stepenu histološke diferencijacije i procene rasta zasnovane na mitotičkom indeksu. Pored toga, jedan od načina klasifikacije se zasniva na proceni stepena atipičnosti ćelija i jedra u odnosu na normalno stanje (Schulz, 2007). Podela se može izvršiti na osnovu veličine tumora (T1-T4), proširenosti na regionalne limfne čvorove, veličine, broja i distribucije invadiranih limfnih čvorova (N0, N+) i prisustva udaljenih metastaza (M0, M+). Poslednji navedeni kriterijumi za određivanje stadijuma tumora se zasnivaju na primeni TNM (engl. Tumor-Node-Metastasis) klasifikacije, koja se dugi niz godina koristi u cilju odabira adekvatne terapije i prognoze (Lindenblatt i 
sar., 2012; Sobin i Wittekind, 2002). Međutim, ova klasifikacija pretpostavlja linearnu progresiju tumora, čime je relativno pojednostavljena i ne uzima u obzir molekularne promene koje leže u osnovi neoplastične transformacije (Ruddon, 2007; Schulz, 2007). Sa brzim razvojem i istraživanjima iz oblasti molekularne genetike, moderna onkologija nastoji da poveže terapiju i prognozu ishoda bolesti sa proučavanjem molekularne biologije tumorske ćelije te da pronađe validne molekularne biomarkere, čime bi do sada korišćeni princip TNM klasifikacije pretrpeo izvesne promene i bio unapređen (Burke, 2004). Stoga su brojna istraživanja usmerena na pokušaj integracije bioloških-molekularno genetičkih nalaza i kliničkog određivanja stadijuma bolesti, čime bi postojeće standardne klasifikacije tumora bile dopunjene ili izmenjene preciznijim određivanjem stadijuma bolesti.

\subsection{Oralni skvamocelularni karcinom}

Oralni skvamocelularni karcinom (engl. ㅁral $\underline{\text { Squamous }}$ Cell CarcinomaOSCC) koji je, prema podacima Svetske Zdravstvene Organizacije jedanaesto maligno oboljenje u humanoj populaciji, predstavlja podgrupu karcinoma glave i

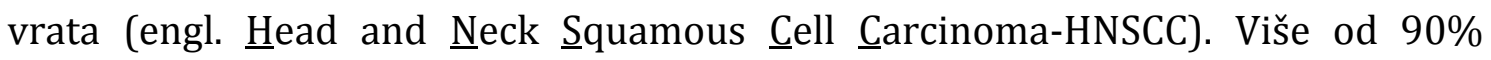
maligniteta gornjih disajnih puteva i maksilofacijalne regije su skvamocelularni karcinomi (Johnson i sar., 2011; Lambert i sar., 2011; Warnakulasuriya 2009). Od svih karcinoma glave i vrata, 44\% čine karcinomi oralne duplje, u koje spadaju karcinomi jezika (prve 2/3 jezika), poda usne duplje, tvrdog nepca, usana i bukalne sluzokože (Pfister i sar., 2011) (Slika 1.). 


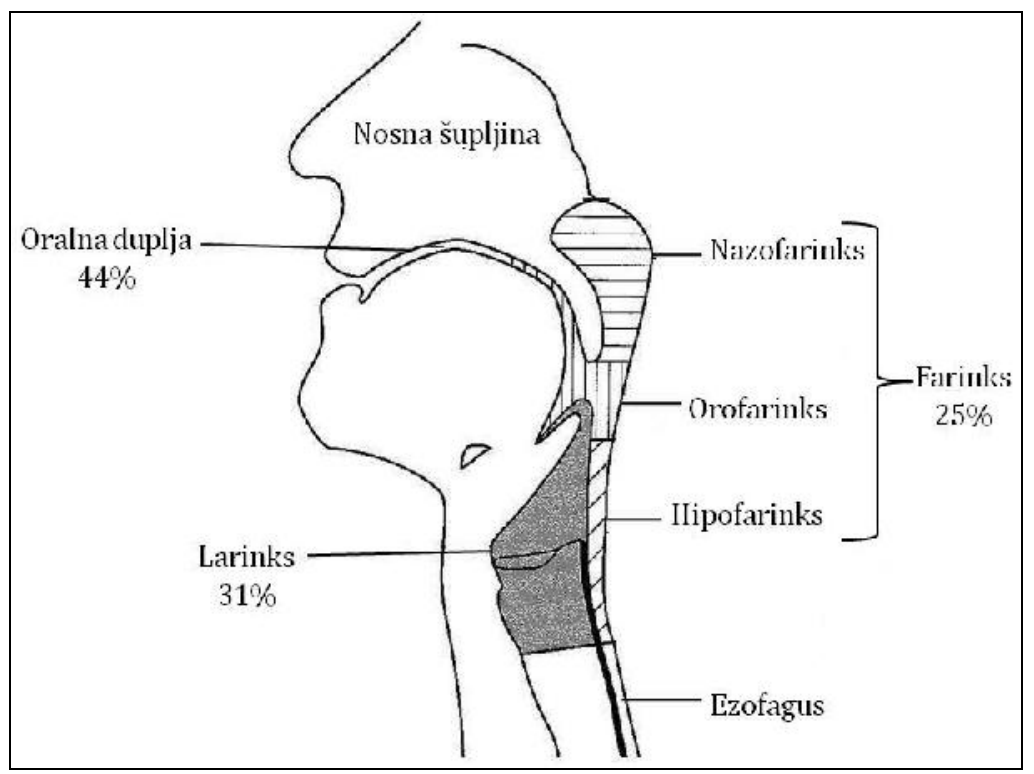

Slika 1. Tumori glave i vrata (preuzeto: Pfister i sar., 2011, modifikovano)

Oralni skvamocelularni karcinomi se karakterišu visokom stopom mortaliteta, lošom prognozom i porastom incidence $\mathrm{u}$ razvijenim zemljama, kao i među mlađom populacijom i osobama srednjeg životnog doba (Hunter i sar., 2005). I pored napredaka na polju prevencije oralnih karcinoma, petogodišnja stopa preživljavanja je ostala gotovo nepromenjena poslednjih 20 godina (Mascolo i sar., 2012). Kod pacijenata se i dalje često javljaju regionalni recidivi i udaljene metastaze (Rene-Lemans i sar., 2011). Loša prognoza je najverovatnije rezultat slabog odgovora na postojeću terapiju, uglavnom tumora dijagnostikovanih u uznapredovalom stadijumu (Mascolo i sar., 2012).

Po pitanju učestalosti OSCC-a u svetu, zapažena je razlika u pogledu geografskih regiona (Slika 2.). Visoka incidenca je karakteristična za južnu i jugoistočnu Aziju (Šri Lanka, Indija, Pakistan, Tajvan), delove zapadne (Francuska) i istočne Evrope (Mađarska, Slovačka, Slovenija), delove Južne Amerike (Brazil, Urugvaj, Porto Riko) i Kariba i Melanezija (Papua Nova Gvineja) (Lambert i sar., 2011; Warnakulasuriya, 2009; Johnson i sar., 2011; Scully i Bagan, 2009). Što se tiče Evrope, najviša incidenca je zabeležena u Francuskoj i Mađarskoj, a najmanja u Grčkoj i na Kipru (Warnakulasuriya, 2009). Generalno govoreći, zastupljenost OSCC-a je viša u zapadnoj u poređenju sa istočnom i južnom Evropom. Sa druge strane, podaci GLOBOCAN za 2008 godinu pokazuju da je najviša incidenca 
karcinoma oralne duplje zabeležena u Melaneziji, centralnoj i južnoj Aziji, centralnoj i istočnoj Evropi, a najniža u Africi, centralnoj Americi i istočnoj Aziji među pripadnicima oba pola (Jemal i sar., 2011; Johnson i sar., 2011).

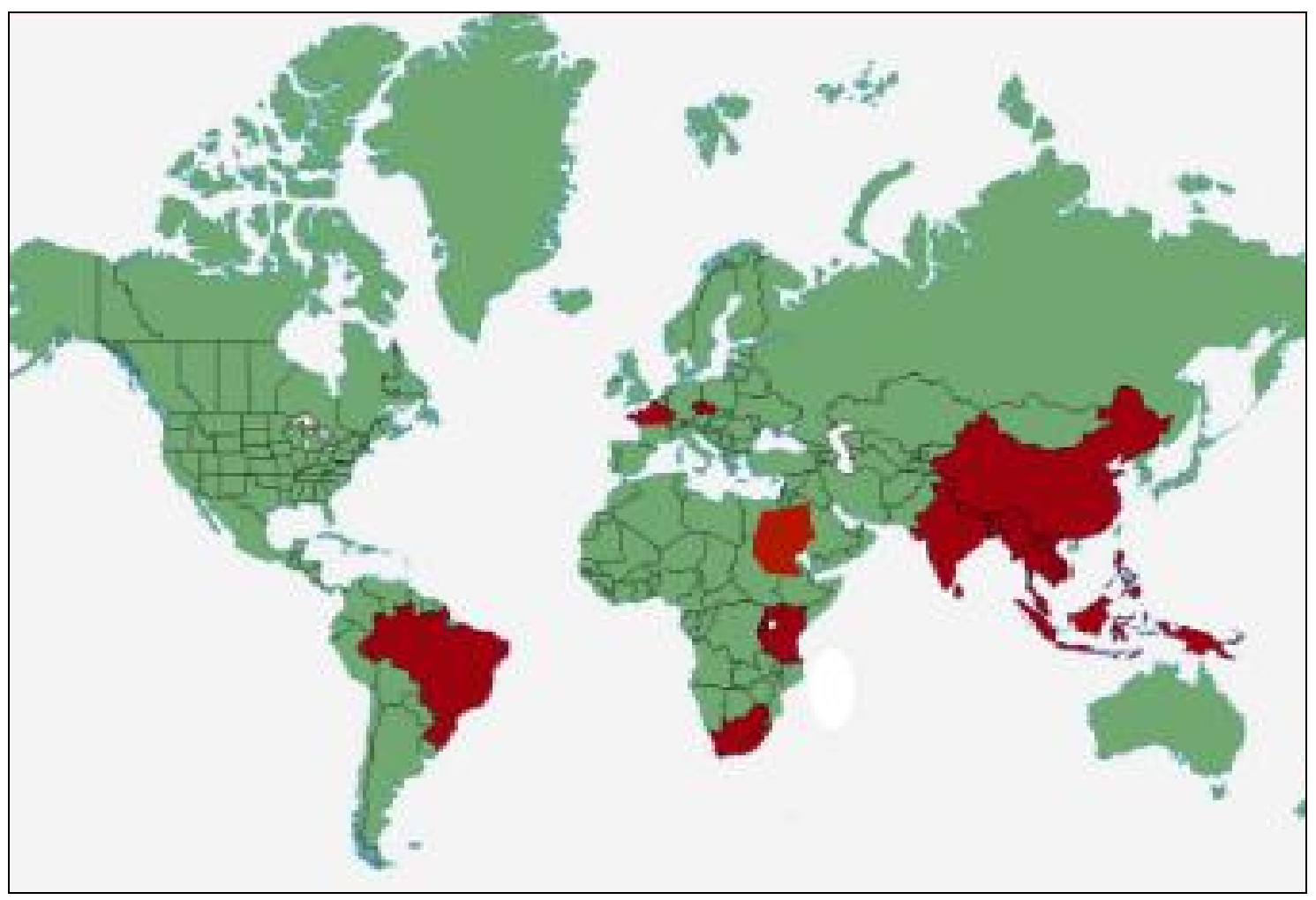

Slika 2. Zemlje sa visokom incidencom i mortalitetom od oralnog karcinoma (preuzeto: Warnakulasuriya, 2009, modifikovano)

Ovakva distribucija zastupljenosti OSCC-a u svetu ukazuje na značajnu ulogu etioloških faktora u razvoju bolesti i to: konzumiranja alkohola, pušenja i žvakanja duvana. Korišćenje genotoksične biljke betel, u čije se listove umotavaju mešavina areka oraha, praha kateha akacije i duvan, je tradicionalni običaj koji upražnjava oko 20\% svetske populacije pretežno u Indiji, Papua Novoj Gvineji i Kini, gde je incidenca OSCC-a značajno viša u odnosu na ostatak sveta (Scully i Bagan, 2009; Nair i sar., 2004). Najčešća mesta za razvoj lezija u oralnoj duplji su ventralna strana jezika i pod usne duplje, verovatno zato što se upravo u tom regionu sakupljaju kancerogeni. Zabeleženo je da se incidenca javljanja kancera usana smanjuje već decenijama u Sjedinjenim Američkim Državama (Silverman, 2001). 
Prema podacima Republičkog Zavoda za zdravlje Srbije, smrtnost od karcinoma glave i vrata u Srbiji je porasla za 19.1\% u periodu od 1977-2000 godine (Broćić, 2008). Mortalitet od OSCC-a u periodu od 1995-2000 godine iznosi 0.95\% ukupnog mortaliteta uzrokovanog malignim oboljenjima, što je za $0.20 \%$ više u odnosu na period od 1990-1995. Na području grada Beograda, mortalitet od karcinoma glave i vrata predstavlja $2 \%$ svih malignih tumora, pri čemu je zabeležena tendencija povećanja za $77 \%$ u poslednjih dvadeset godina (Broćić, 2008).

Brojnim studijama je pokazano da korišćenje duvana i alkohola povećava rizik za razvoj karcinoma glave i vrata na dozno-zavisan način i da su efekti dejstva ovih faktora sinergističke, a ne aditivne prirode (Ragin i sar., 2007). Rizik za razvoj oralnog karcinoma kao rezultat sinergističkog dejstva duvana i alkohola se procenjuje na preko $80 \%$. Procenjuje se da alkoholičari i pušači imaju od 40 do 50 puta veći rizik za razvoj OSCC-a od nepušača i nealkoholičara (Warnakulasuriya, 2009; Petti i Scully, 2005). Biološko objašnjenje ovog fenomena leži u pretpostavci da etanol oštećuje oralnu mukozu čime bar delimično povećava permeabilnost mukoze za kancerogene prisutne u duvanu i one koji su proizvod metabolizma etanola u oralnoj duplji kao npr. acetaldehid (Petti i Scully, 2005; Broćić i sar., 2011). Smatra se da konzumiranje marihuane takođe ima ulogu u razvoju karcinoma glave i vrata (Hunter i sar., 2005; Johnson i sar., 2011).

Loša oralna higijena se smatra jednim od potencijalnih etioloških faktora i takođe može imati ulogu u nastanku OSCC-a (Scully i Bagan, 2009). Takođe, ispiranje usne duplje alkoholnim rastvorima je asocirano sa nastankom oralnog karcinoma.

Razlika u učestalosti javljanja oralnog skvamocelularnog karcinoma, kao i stopi preživljavanja je zabeležena i među polovima (Warnakulasuriya, 2009; Silverman, 2001). Od dijagnostikovanih karcinoma 66-95\% je zabeleženo među pripadnicima muškog pola (Silverman, 2001). U visoko rizičnim zemljama kao što su Indija, Pakistan i Bangladeš, oralni karcinom je najčešći kod muškaraca i dostiže do 25\% svih novo dijagnostikovanih slučajeva kancera (Warnakulasuriya, 2009). Prema nekim podacima, diskrepanca u oboljevanju od oralnog karcinoma između polova se polako smanjuje i odnos je blizu 1.8:1 u korist muškog pola, ali polako 
smanjenje razlike se objašnjava povećanom i prolongiranom upotrebom duvana i alkohola među pripadnicama ženskog pola (Silverman, 2001). Stopa petogodišnjeg preživljavanja od oralnog karcinoma širom sveta je manja od 50\%, iako žene generalno imaju višu stopu relativnog preživljavanja u odnosu na muškarce (Ragin i sar., 2007).

Smatra se da su i godine značajan faktor rizika, na šta ukazuje podatak da je oko $90 \%$ oralnih karcinoma detektovano kod osoba starijih od 45 godina, što se može objasniti prolongiranom izloženošću sredinskim kancerogenima, dugogodišnjim pušenjem, konzumiranjem alkohola, izloženošću virusima, lošom ishranom (Silverman, 2001). Oko 6\% oralnih karcinoma se registruje kod mlađih osoba ispod 45 godina starosti (Warnakulasuriya, 2009). Statistički podaci pokazuju da je oko 25\% mladih ispod 45 godina života izloženo nekom od poznatih faktora rizika (Llewellyn i sar., 2004). Međutim, zabrinjavajući je podatak da je incidenca OSCC-a u porastu među osobama između 20 i 30 godina, koji nisu izloženi ni jednom od poznatih faktora rizika, čak i u razvijenim zemljama kao što su Sjedinjene Američke Države, Velika Britanija i Norveška (Hunter i sar., 2005).

„Rasa“ i etnička pripadnost mogu biti značajni za razvoj OSCC-a, što zbog genetičke predispozicije, ali verovatno i socioekonomskih faktora (dostupnost zdravstvenog sistema, loša prevencija i rana detekcija kancera). Najviša incidenca i stopa smrtnosti od oralnog karcinoma je detektovana među crncima (Silverman, 2001). Stopa petogodišnjeg preživljavanja Afro Amerikanaca iznosi 39.5\% što je značajno manje u odnosu na stopu preživljavanja Kavkazijanca od 61.8\%. Ovakav trend petogodišnjeg preživljavanja među „rasama“ se nije promenio tokom poslednje tri decenije (Ragin i sar., 2007).

Pored navedenih, značajan faktor rizika za razvoj OSCC-a je infekcija humanim papiloma virusom (engl. Human Papilloma Virus- HPV), a posebno visoko rizičnim tipovima HPV16 i HPV18. Oko 20-25\% karcinoma glave i vrata sadrži onkogene HPV tipove, ali pretežno HPV16 (Ragin i sar., 2007). HPV16 i HPV18 su detektovani u 30\% OSCC-a, dok se ostali visokorizični tipovi javljaju u učestalosti manjoj od 1\% kod ovih karcinoma (Ragin i sar., 2007). HPV proteini odgovorni za poremećenu regulaciju tumor supresorskih funkcija, transformaciju i stimulaciju rasta koja vodi kancerogenezi, su proteini E6 i E7, produkti virusnih 
onkogena E6 i E7. Naime, kod HPV pozitivnih karcinoma glave i vrata, oko 11-50\% eksprimira E6 i E7 transkripte, što ukazuje da prisustvo HPV-a ne podrazumeva uvek da je virus transkripciono aktivan. Činjenica da prisustvo virusnih onkogena E6 i E7 nije detektovano u svim HPV pozitivnim karcinomima ukazuje da HPV infekcija nije jedini i isključivi faktor rizika za razvoja OSCC-a, kako se ispočetka mislilo (Ragin i sar., 2007).

Sa razvojem nutrigenomike, veliki značaj se pridaje ishrani, kao važnom faktoru za prevenciju razvoja kancera (Ross, 2010; Milner, 2008), pa samim tim i oralnog karcinoma. Neka istraživanja procenjuju da je oko $30-40 \%$ svih kancera uzrokovano upravo neadekvatnom ishranom, ali ova procena zavisi i od hrane koja se koristi i tipa kancera (Davis i Milner, 2007). Ipak, balansirana ishrana i korišćenje namirnica bogatih antikancerogenim i antioksidativnim jedinjenjima, pretežno voća i povrća, se smatra bitnim u cilju predupređivanja kancerogeneze (Lambert i sar., 2011). Procenjeno je da se korišćenjem voća i povrća svakog dana za 50\% smanjuje rizik od razvoja oralnog karcinoma (Conway, 2007). Korišćenje voća u ishrani, prevashodno citrusa ima veći protektivni značaj u odnosu na ishranu bogatu povrćem (Johnson i sar., 2011). Mnogobrojne studije su pokazale da korišćenje folata u značajnoj meri može smanjivati rizik od oboljevanja (Pelluchi i sar., 2003). Interesantan je podatak da interakcije između nutritivnih komponenata mogu uticati na podložnost razvijanja kancera, modifikujući dozu nutrijenta koji je potreban da bi se ostvario odgovarajući fiziološki efekat. Pokazano je da male doze retinoične kiseline i vitamina D, kada se daju odvojeno, nemaju efekat na prevenciju kancera dojke, dok pokazuju visok stepen efektivnosti kada se daju zajedno (Davis i Milner, 2007). Smatra se da je kombinacija korišćenja duvana i alkohola, zajedno sa lošom ishranom voćem i povrćem, povezana sa povećanom incidencom HNSCC-a kod mlađe populacije (Hunter i sar., 2005).

Ipak, činjenica da samo određeni procenat osoba koji su pod uticajem poznatih faktora rizika zaista i razvije oralni karcinom, sugeriše na postojanje značajne genetičke osnove (Scully i Bagan, 2007). Interakcije između genetičkih, epigenetičkih i sredinskih faktora mogu imati bitnu ulogu u etiologiji oralnog karcinoma. Sa razvojem personalizovane medicine, velika sredstva se ulažu u molekularno genetičke studije, koje nastoje da rasvetle uticaj genetičke osnove za 
razvoj različitih bolesti, a pre svega kancera, kao vodećeg uzročnika smrtnosti u svetu. Pored značajnih napora uloženih u karakterizaciju oralnog karcinoma i hirurških zahvata za njihovo uklanjanje, odsustvo rane senzitivnije dijagnostike i visoka incidenca regionalnog i lokalnog recidiva nameće potrebu za detaljnije ispitivanje molekularnih osnova patogeneze oralnog skvamocelularnog karcinoma. Identifikacija i uvođenje novih molekularnih markera u dijagnostičke, terapeutske i prognostičke svrhe bi, potencijalno moglo značajno da utiče na smanjenje incidence razvijanja bolesti, kao i na uspešnije medicinske tretmane.

\subsubsection{Genetička osnova oralne kancerogeneze}

Oralna kancerogeneza predstavlja heterogeni višestepeni proces koji se ogleda u promeni histologije oralnog tkiva, od normalnog, neizmenjenog tkiva ka hiperplaziji, displaziji, karcinoma in situ i invazivnog karcinoma (Slika 3.) (Forastiere i sar., 2001; Rene-Leemans i sar., 2011; Choi i Myers, 2008). Neoplazije se razvijaju klonalno iz transformisanih ćelija koje su pretrpele brojne genetičke promene (Lingen i sar., 2011). Do akumulacije genetičkih promena dolazi usled postojanja genetičke predispozicije (velikog broja genetičkih i epigenetičkih promena koje mogu voditi genomskoj nestabilnosti, tumorskom razvoju i progresiji (Mascolo i sar., 2012)), kao i uticaja faktora spoljašnje sredine, gde se najviši značaj pridaje korišćenju duvana, alkohola, hroničnim inflamacijama i virusnim infekcijama (Perez-Sayans i sar., 2009; Mascolo i sar., 2012). Molekularno genetičke promene najčešće pogađaju protoonkogene i tumor supresor gene, koji se mogu inaktivirati ili prekomerno eksprimirati usled mutacija, gubitka heterozigotnosti (Loss of Heterozygosity-LOH), amplifikacija i/ili delecija i epigenetičkih modifikacija (Perez-Ordonez i sar., 2006; Lingen i sar., 2011). Pored protoonkogena i tumor supresor gena, genetičke promene pogađaju i druge gene koji su uključeni u održavanje homeostaze, proliferacije i diferencijacije ćelija. Promene se mogu detektovati primenom molekularno genetičkih tehnika $u$ svakom od stupnjeva bolesti ili kancerogeneze (Lingen i sar., 2011). 


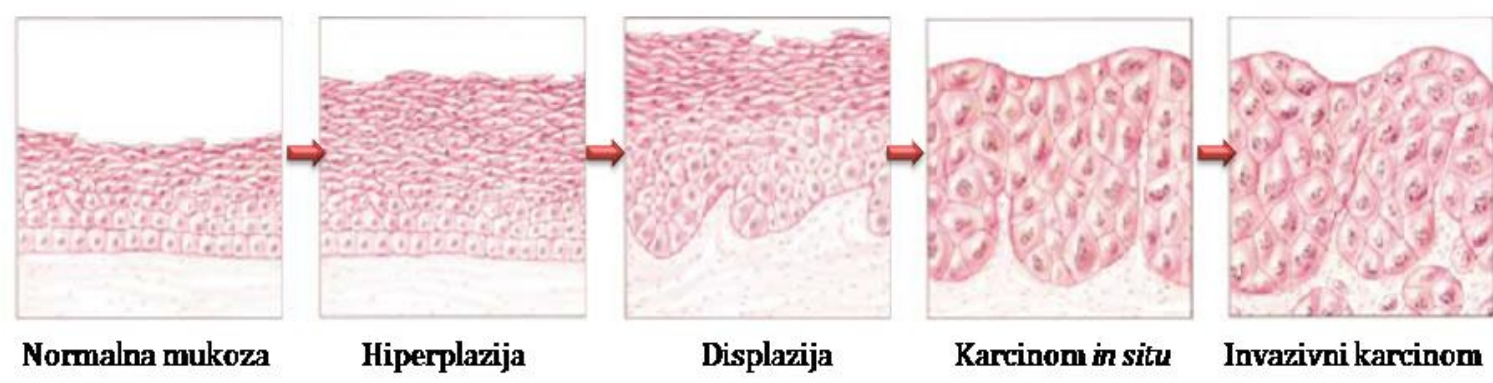

Slika 3. Hipotetički model oralne kancerogeneze (preuzeto: Forastiere i sar., 2001, modifikovano)

Niz hromozomskih promena je brojniji sa svakim narednim histološkim stadijumom, počev od benigne hiperplazije, displazije, karcinoma in situ do invazivnog karcinoma (Tabela 1.). Promene na hromozomima, tačnije LOH 3p, 9p i $17 \mathrm{p}$ su najčešće na stadijumu displazije, te se stoga mogu smatrati ranim markerima oralne kancerogeneze, dok je LOH $8 p$ i 13q češći u kasnijim stupnjevima kancerogeneze (Choi i Myers 2008) (Tabela 1.). Najčešća genetička promena koja se dešava u ranim fazama progresije je gubitak hromozomskog regiona 9p21, usled čega dolazi do inaktivacije p14 i p16 gena, inhibitora ciklinzavisnih kinaza koje imaju ključnu ulogu u regulaciji ćelijskog ciklusa-ćelijske proliferacije (Perez-Sayans i sar., 2009). LOH 9p21 regiona je detektovan u 70-80\% slučajeva karcinoma glave i vrata (Perez-Ordonez i sar., 2006). Generalno govoreći, lokus 9p21 predstavlja najosetljiviji deo humanog genoma kada je reč o oralnom karcinomu i njegova delecija je povezana sa lošom prognozom (Scully i sar., 2000).

Za većinu oralnih karcinoma II i III tumorskog stadijuma, kao i IV stadijuma karcinoma glave i vrata, zabeležen je LOH 3p (Scully i sar., 2000), koji predstavlja drugu po redu najčešću genetičku promenu u oralnoj kancerogenezi, sa učestalošću 60-70\% (Perez-Ordonez i sar., 2006). Primenom komparativne genomske hibridizacije je pokazano da se često dešava delecija na hromozomskoj poziciji 3p14, što predstavlja mesto tumor supresor gena kandidata (Hunter i sar., 2005). Pored ovog regiona, zabeležen je LOH sledećih regiona: 3p21, 3p22, 3p24 i 3p26 (Perez-Ordonez i sar., 2006). Delecije 2q21-24, 2q33-35 i 2q37 takođe 
dovode do gubitka brojnih tumor supresor gena uključujući CASP8, CASP10, BARD1, ILKAP, ING5 i druge (Perez-Sayans i sar., 2009).

Tabela 1. Najčešće detektovane genetičke promene na različitim histološkim stadijumima oralne kancerogeneze

\begin{tabular}{|lc|}
\hline \hline \multicolumn{1}{|c|}{ Stadijum } & Genetičke promene \\
\hline \hline Normalna mukoza-hiperplazija & LOH 9p21 \\
& Inaktivacija p14/p16 \\
Trizomija 7 & EGFR \\
& Aktivacija telomeraze \\
\hline Hiperplazija-displazija & \\
& LOH 3p \\
& LOH 17p13 (p53 gen) \\
& Tetraploidija \\
\hline Displazija-karcinom in situ & LOH 11q13 \\
& LOH 13q21 \\
& del 8p \\
& Aneuploidija \\
& Amplifikacija ciklina D1 \\
\hline Karcinom in situ-invazivni karcinom & del 18q \\
& LOH 10q23 \\
& LOH 3p26 \\
& \\
\hline \hline
\end{tabular}

Gubitak heterozigotnosti na hromozomskoj poziciji $17 \mathrm{p}$ je zabeležen $\mathrm{u}$ premalignim oralnim lezijama i ranim stadijuma kancerogeneze (Perez-Sayans i sar., 2009). Polovina od svih karcinoma glave i vrata sadrži mutaciju u p53 genu koji se nalazi na hromozomu 17p13 (Perez-Ordonez i sar., 2006). Gubitak funkcije p53 kao posledica mutacije u ovom genu, rezultira progresijom iz preinvazivnih $u$ invazivne lezije i značajnom povećanju verovatnoće za dalju progresiju bolesti i lošu prognozu (Forastiere i sar., 2001; Scully i sar., 2000). 
U uznapredovalim tumorskim stadijumima i slabo diferenciranim karcinomima se često mogu naći druge aberacije, kao što je gubitak alela na pozicijama 5q21-22, 22q13, 4q, 11q, 18q i 21q (Perez-Sayans i sar., 2009).

Analiza genske ekspresije, microarray metodom, je pokazala da postoji statistički značajna razlika u ekspresiji čak 426 gena, od kojih je 322 (75.58\%) imalo povećanu, a 104 (24.42\%) smanjenu ekspresiju u zdravom tkivu $u$ poređenju sa tumorskim tkivom pacijenata sa dijagnostikovanim oralnim karcinomom (Perez-Sayans i sar., 2009). Iako je drugim studijama pokazana izmenjena ekspresija drugih gena, interesantno je da je biološka funkcija analiziranih gena $\mathrm{u}$ obe studije bila identična. $U$ oralnim karcinomima je zabeležena povećana ekspresija CCND1 gena, koja može dovesti do povećane ekspresije proteina ciklina D1 koji je asociran sa povećanom stopom metastaza $\mathrm{u}$ limfnim čvorovima i lošom prognozom u ranim stadijumima oralnog tumora (Perez-Sayans i sar., 2009). Amplifikacija 11q13 i povećana ekspresija ciklina D1 je registrovana u 30-60\% slučajeva karcinoma glave i vrata (Perez-Ordonez i sar., 2006).

Epigenetičke promene takođe imaju izuzetno važnu ulogu u multistepenom procesu oralne kancerogeneze (Mascolo i sar., 2012; Šupic i Magić, 2009). Epigenetičke promene obuhvataju nasledne modifikacije u genskoj ekspresiji bez promene primarne DNK sekvence i to: metilaciju DNK, histonsku modifikaciju i uticaj regulatornih nekodirajućih RNK na gensku ekspresiju (Herman i Baylin, 2003; Šupic i Magić, 2009). Geni koji su hipermetilovani u oralnom karcinomu su uključeni u širok spektar ćelijskih procesa, kao što su regulacija ćelijskog ciklusa (p15, p16), apoptoza (p14, DAPK, p73, RASSF1A), Wnt signalni put (APC, WINF1, RUNX3), ćelijska adhezija (E-kadherin) i popravka DNK (MGMT i hMLH1) (Mascolo i sar., 2012; Perez-Sayans i sar., 2009). Za razliku od drugih genetičkih promena, epigenetičke promene su potencijalno reverzibilne.

Što se tiče molekularno genetičkih promena koje se javljaju kod mlađih pacijenata u odnosu na starije, zabeležena je značajno viša učestalost mikrosatelitske nestabilnosti (kratkih varijabilnih ponovaka na DNK) kod mlađih osoba (88\%) u poređenju sa starijom grupom pacijenata (36\%) (Wang i sar., 2001). Međutim, mehanizam mikrosatelitske nestabilnosti u karcinomima glave i 
vrata i oralnog karcinoma nije do kraja rasvetljen, s obzirom da nisu detektovane mutacije i metilacija promotora gena uključenih u reparaciju DNK molekula (Perez-Ordonez i sar., 2006).

Saznanja iz oblasti humane molekularne i populacione genetike imaju veliki uticaj na medicinske nauke i praksu. Razumevanje molekularnih puteva uključenih u nastanak bolesti, omogućava nalaženje novih ciljeva za lečenje. Istovremeno, mogućnost predikcije podložnosti bolesti, kao i klasifikacija bolesti u subtipove na osnovu genetičke informacije, će rezultovati poboljšanim medicinskim tretmanom i većom upotrebom farmakogenetike $u$ individualnom lečenju. $U$ tom smislu je važno uzeti u obzir varijabilnost humanog genoma, a posebno najzastupljenijeg tipa varijabilnosti: polimorfizme nukleotidne sekvence.

Pored prethodno navedenih detektovanih genetičkih promena koje se nalaze u osnovi oralne kancerogeneze, postavlja se pitanje da li postojanje genetičkih varijacija određenih gena u humanom genomu može imati uticaj na razvoj oralnog karcinoma.

\subsection{Polimorfizmi nukleotidne sekvence}

Genetičke varijacije u humanom genomu se mogu podeliti na česte i retke varijante, na osnovu razlike u učestalosti najređeg ili minor alela (engl. Minor Allele Frequency- MAF) u humanim populacijama. Česte genetičke varijante se još nazivaju i polimorfizmi.

Pod genetičkim polimorfizmom se podrazumevaju alelske varijante koje se javljaju stabilno u populaciji u učestalosti koja je dovoljno velika da se ne smatra samo proizvodom mutacionog procesa i generalno je veća od 1\%, za razliku od retkih varijanti gde je učestalost najređeg alela manja od 1\% (Frazer i sar., 2009). U humanom genomu su najzastupljeniji polimorfizmi nukleotidne sekvence (engl. Single Nucleotide Polymorphism- SNP) (Frazer i sar., 2009). SNP predstavlja genetičku promenu ili varijaciju u sekvenci DNK u jednom od četiri nukleotida u genomu, koji se razlikuje između jedinki iste vrste ili parova hromozoma iste jedinke. Rezultatima sekvenciranja je procenjeno da humani genom sadrži 
najmanje 11 miliona SNP-ova, pri čemu oko 7 miliona ima učestalost minor alela preko 5\%, a ostatak između 1-5\% (Frazer i sar., 2009). Prema procenama, otprilike jedan na svakih 500-1 000 nukleotida u humanoj DNK može biti SNP. Ako se uzme u obzir veličina humanog genoma od 3.2 milijarde baznih parova, procenjeno je da oko 1 milion razlika, koje postoje između dva genoma, predstavljaju rezultat postojanja SNP-ova, što čini oko 85\% genetičke varijabilnosti kod čoveka. Takođe je važno napomenuti da postoje varijacije između humanih populacija, tako da SNP aleli koji su česti u jednom geografskom regionu ili etničkoj grupi mogu biti mnogo ređi u drugoj.

SNP može postojati unutar promotorskog regiona, egzona (kodirajućeg regiona gena), introna (nekodirajućeg regiona gena) ili intergenskih regiona. Interesovanje istraživača je posebno fokusirano na SNP-ove pronađene unutar kodirajuće sekvence, jer je verovatnije da oni menjaju biološku funkciju proteina. Međutim, SNP-ovi unutar kodirajućeg regiona gena ne menjaju neizbežno redosled amino kiselina kodiranog proteina, zbog izrođenosti genetičkog koda. SNP-ovi identifikovani unutar introna imaju verovatno manji biološki efekat. Polimorfizmi nukleotidne sekvence unutar promotorskog regiona su najučestaliji.

Kada je reč o nomenklaturi SNP-ova, u najširoj upotrebi je označavanje pozicije nukleotida od startnog mesta transkripcije, pri čemu negativan predznak ukazuje da se polimorfizam nalazi u promotorskom regionu, a pozitivan da je u intronu ili egzonu. U današnje vreme je daleko zastupljenije obeležavanje polimorfizama na osnovu jedinstvenog registarskog broja, takozvani rs broj (engl. Reference SNP ID number), na osnovu koga se može pretraživati u dostupnoj SNP bazi podataka (www.ncbi.nlm.nih.gov/SNP).

Pored SNP-ova postoji jako veliki broj retkih ili de novo varijanti jednog nukleotida. Na primer, bilo koji izmenjeni bazni par koji je kompatibilan sa životom se može pronaći u najmanje jednom od 6.7 milijardi ljudi na Zemlji (Frazer i sar., 2009).

SNP-ovi blisko locirani na hromozomu se mogu nalaziti u vezanoj neravnoteži (videti sledeće poglavlje).

$\mathrm{Na}$ osnovu podataka dobijenih analizom SNP-ova, može se dosta saznati o evolucionoj prošlosti humanih populacija. Istovremeno, takvi podaci predstavljaju 
i bogat izvor za razvijanje posebne grane medicine tzv. genetičke medicine. Naime, postojanje različitih varijacija sekvence DNK kod ljudi može imati izvesne posledice po pitanju podložnosti bolestima, odgovoru na patogene, hemikalije, lekove, vakcine i druge agense. Poznavanje i proučavanje SNP-ova predstavlja značajan izvor za razumevanje genetičke osnove velikog broja složenih bolesti. Genomskim studijama asocijacije (engl. Genome Wide $\underline{A} s s o c i a t i o n ~ \underline{S} t u d i e s-$ GWAS) se ispituju povezanosti određenih alelskih varijanti sa rizikom tj. podložnošću razvijanja bolesti. Stoga se smatra da su SNP-ovi ključ u omogućavanju realizacije koncepta personalizovane medicine, te se u današnje vreme rapidno povećava broj biomedicinskih istraživačkih radova koji imaju za cilj determinaciju polimorfizama koji bi imali ulogu izvesnih molekularnih markera i važnih terapeutskih i prognostičkih faktora.

\subsection{Gametska neravnoteža vezanosti}

Pod konceptom gametske neravnoteže vezanosti (engl. Linkage Disequilibrium- LD) se podrazumeva neslučajna asocijacija alela/polimorfizama na različitim lokusima i njihova vezana, zajednička segregacija u gamete (Collins, 2008; Slatkin, 2008; Wall i Pritchard, 2003). Ovaj termin su prvi put upotrebili naučnici Lewontin i Kojima još 1960. godine. Tokom osamdesetih godina XX veka, interesovanje za LD je naglo poraslo. Tako je jedan od zadataka prve faze internacionalnog HapMap projekta bilo raščlanjivanje genoma u grupe visoko vezanih SNP-ova koji se nasleđuju zajedno (tzv. LD ili haplotipski blokovi) (www.hapmap.org). U drugoj fazi je predstavljeno da se velika većina SNP-ova može svesti na oko 550000 LD blokova kod individua Evropskog i Azijskog porekla i 1100000 LD blokova kod individua Afričkog porekla. Generalno gledano, koncept LD-a nam daje uvid u populacionu prošlost, mapiranje gena koji su u asocijaciji sa kvantitativnim osobinama i naslednim bolestima, kao i razumevanje evolucije vezanih setova gena.

Prema veličini haplotipski blokovi kod ljudi variraju od nekoliko kb do više od $100 \mathrm{~kb}$ (u proseku oko $50 \mathrm{~kb}$ ), pri čemu su kraći blokovi karakteristični za 
Afričke populacije i generalno za izolovane populacije (Collins, 2008; Slatkin, 2008). Haplotipski blokovi su predstavljali iznenađujuće otkriće velikog praktičnog značaja za mapiranje naslednih bolesti. Otkrićem haplotipskih blokova je pokazano da LD blokovi zauzimaju mnogo veće hromozomske distance, tako da testiranje jednog SNP-a unutar jednog bloka na asocijacije sa bolestima može biti dovoljno da ukaže na postojanje asocijacije sa svakim SNP-om u datom bloku (Collins, 2008). Očigledan je praktični značaj, s obzirom da se primenom navedene logike smanjuje broj SNP-ova koji bi trebalo da budu testirani u uzoračko-kontrolnim studijama asocijacije sa bolestima.

Najvažniji parametri za merenje jačine LD-a su r² i D'. Obe mere mogu imati vrednosti u rangu od 0 (odsustvo vezanosti-neravnoteže) do 1 (potpuna vezanostneravnoteža) (Wall i Pritchard, 2003). Danas je dostupan veliki broj programa za merenje jačine LD-a, haplotipske analize i procene haplotipskih učestalosti $u$ grupama nesrodnika uzoračko-kontrolnih studija (Barrett i sar., 2005; Fallin i Schork, 2000).

\subsection{Vitamin D}

Vitamin D je otkriven krajem XIX veka, zahvaljujući sprovođenju brojnih eksperimenata koji su imali za cilj pronalaženje uzročnika bolesti rahitisa. Još od početka XIX veka je bilo poznato da se nastanak rahitisa može preduprediti izlaganjem Sunčevom zračenju. Nemački naučnici su 1919. godine pokazali da se za lečenje rahitisa može koristiti i veštačko ultravioletno zračenje. 1923. godine je naučno potvrđeno da se vitamin D može stvarati izlaganjem 7-dehidroholesterola Sunčevom ili veštačkom ultravioletnom zračenju. Ova mogućnost produkcije vitamina D usled izlaganja Sunčevom zračenju i metabolizma do steroidnog hormona, ukazuje da nije reč samo o vitaminu, već i o hormonu (Dusso i sar., 2005).

Struktura vitamina D je poznata od početka XX veka (Lin i White, 2003). Reč je o steroidnom molekulu, preciznije sekosteroidu, koji se u prirodi javlja u dve forme: vitamin $\mathrm{D}_{3}$ (holekalciferol) i vitamin $\mathrm{D}_{2}$ (ergokalciferol) (Bikle, 2009; Vuolo 
i sar., 2012). Holekalciferol je animalnog porekla i produkuje se u koži pod dejstvom Sunčevog zračenja, dok se ergokalciferol produkuje kod biljaka i kvasaca od biljnog sterola ergosterola (Bikle, 2007).

Vitamin D se može apsorbovati iz namirnica koje su bogate vitaminom D (masne ribe, kao što su : losos, tuna; riblje ulje, jetra, žumance jajeta, sir, sušene pečurke, itd) (Davis i Milner, 2011; Kemmis i sar., 2006). U mnogim zemljama, među kojima je i Srbija, brojne namirnice, kao što su mleko, mlečni proizvodi, margarini, cerealije su obogaćene vitaminom $D$, čime se može značajno povećati unos ovog vitamina (Davis i Milner, 2011). Nakon II svetskog rata, obogaćivanje namirnica vitaminom D nije bilo adekvatno praćeno i kontrolisano, što je vodilo intoksikaciji vitaminom D i hiperkalcemiji, prvenstveno kod dece. Upravo zbog toga, mnoge Evropske države su uvele zabranu obogaćivanja namirnica vitaminom D (Field i Newton-Bishop, 2011).

Najpoznatija fiziološka uloga koju vitamin D ima je regulacija transporta kalcijuma i fosfata kao i uloga u mineralizaciji kostiju. Značaj ove funkcije je pokazan eksperimentima na nokaut (engl. knockout) miševima deficijentnim za neki od gena koji su ključni za metabolički put vitamina D. Gubitak tih gena kod miševa je rezultirao abnormalnom morfologijom kostiju (Deeb i sar., 2007). Međutim, novije opservacije epidemioloških, biohemijskih i molekularno genetičkih studija ukazuju da vitamin D zapravo ima plejotropnu ulogu u regulaciji diferencijacije i proliferacije ćelija, kao i programirane ćelijske smrti- apoptoze, modulaciji imunskog odgovora i kontrolisanju endokrinog sistema (Deeb i sar., 2007; Lin i White, 2003, Dusso i sar., 2005; Bikle, 2009). S obzirom da vitamin D učestvuje u regulaciji proliferacije i diferencijacije brojnih ćelijskih tipova, sve se više ispituju mogućnosti potencijalnog korišćenja vitamina $\mathrm{D}$ i/ili njegovih sintetičkih analoga $\mathrm{u}$ terapeutske svrhe, kao antikancerogenih agenasa i modulatora imunološke funkcije.

Prema aktuelnim podacima, veliki procenat svetske populacije ima deficijenciju vitamina D, oko milijardu ljudi širom sveta (Ramagopalan i sar., 2010; Aung i sar., 2009; Dusso i sar., 2005) uključujući stanovništvo Severne Amerike i Evrope, što je posledica ishrane siromašne vitaminom D, ali i izbegavanje sunčanja i korišćenja zaštite od Sunca, koja u potpunosti može da blokira fotosintezu 
vitamina D (Dusso i sar., 2005; Garland i sar., 2004). Upravo ovakvi epidemiološki nalazi dovode u opravdanu sumnju vezu između vitamina D i podložnosti razvijanja različitih tipova karcinoma, kao što su kolorektalni karcinom, kancer dojke, prostate, oralni karcinomi (Deeb i sar., 2007,), ali i sa razvojem autoimunskih bolesti, respiratornih infekcija, hipertenzije, kardiovaskularnih bolesti i dijabetesa tip I i II (Dusso i sar., 2005; Vuolo i sar., 2012). Značaj vitamina D u prevenciji kancera je pokazan mnogobrojnim epidemiološkim studijama u kojima je primećena asocijacija između incidence javljanja kancera i stepena izlaganja Suncu (Aung i sar., 2009).

Kao indikator statusa vitamina D se koristi nivo glavne cirkulišuće forme vitamina D u plazmi, 25(OH)D $D_{3}$, poznatiji kao kalcidiol (Dusso i sar., 2005), čija je količina oko 1000 puta viša u odnosu na aktivnu metaboličku formu kalcitriol (Lou i sar., 2004). Uočeno je postojanje veze između niskog nivoa vitamina D u serumu i povećanog rizika za razvoj različitih tipova kancera, a posebno kolorektalnog karcinoma, kancera dojke i prostate (Deeb i sar., 2007). Takođe, poznato je da je povećanje od $25 \mathrm{nmol} / \mathrm{L} 25(\mathrm{OH}) \mathrm{D}_{3}$ asocirano sa $17 \%$ smanjenjem morbiditeta i 29\% smanjenjem mortaliteta od malignih tumora uopšte, dok je u slučaju kancera digestivnog sistema zabeležno čak 45\% smanjenje smrtnosti (Giovannucci i sar., 2006). Osobe sa koncentracijom kalcidiola od $82 \mathrm{nmol} / \mathrm{L}$ su imale 50\% manji rizik za razvoj kolorektalnog karcinoma u odnosu na osobe sa nižim nivoom kalcidiola (Deeb i sar., 2007; Gorham i sar., 2005). Pacijenti sa dijagnostikovanim nesitnoćelijskim karcinomom pluća, u ranom stadijumu, sa visokom koncentracijom $25(\mathrm{OH}) \mathrm{D}_{3}$ i visokim unosom vitamina $\mathrm{D}$ u toku lečenja, su imali bolje ukupno preživljavanje i duži period bez pojave recidiva (Zhou i sar, 2007). Kod žena je nizak nivo cirkulišuće forme vitamina $D$ povezan sa povećanim rizikom za nastanak kancera dojke (Alimirah i sar., 2011). Takođe, kod žena u postmenopauzi sa ranim kancerom dojke je registrovan nizak srednji nivo $25(\mathrm{OH}) \mathrm{D}_{3}$ i njegovih prekursora u serumu, dok je dalje smanjenje nivoa serumskog $25(\mathrm{OH}) \mathrm{D}_{3} \mathrm{u}$ korelaciji sa progresijom bolesti i pojavom metastaza. Pored toga, niži nivo serumskog $25(\mathrm{OH}) \mathrm{D}_{3}$ je naveden kao faktor rizika za razvoj kolorektalnog karcinoma i kancera prostate (Osborne i Hutchinson, 2002). Svi ovi podaci jasno ukazuju da je nizak nivo vitamina D važan faktor rizika za razvoj maligniteta. 
Već neko vreme je poznato da postoje značajne rasne/etničke razlike $\mathrm{u}$ nivou vitamina D u serumu. Osobe Afričkog porekla imaju oko dva puta niži nivo 25(OH) $\mathrm{D}_{3}$ u serumu u poređenju sa individuama Evropskog porekla (Roff i sar., 2008; Garland i sar., 2004). Afro Amerikanci imaju niži prosečni nivo $25(\mathrm{OH}) \mathrm{D}_{3} \mathrm{u}$ poređenju sa Kavkazijancima iz Sjedinjenih Američkih Država, pri čemu se insuficijencija vitamina D kreće u opsegu od 40-80\% (Signorello i sar., 2011). U poređenju sa belcima, kod Afro Amerikanaca je značajno viša učestalost karcinoma kolona, prostate i dojke, što se dovodi u vezi u vezu sa nižim nivoom vitamina D u cirkulaciji, ali ukazuje i na izvesnu ulogu polimorfnih varijanti u genima uključenih u put metabolizma vitamina D, koji mogu imati uticaj na ispoljavanje ovih razlika (Roff i sar., 2008).

Da bi bio fiziološki aktivan i obavljao sve prethodno navedene biološke funkcije, vitamin $\mathrm{D}$ se prevodi $\mathrm{u}$ metabolički aktivnu formu, $1 \alpha 25(\mathrm{OH})_{2} \mathrm{D}_{3}$, poznatiju kao kalcitriol, koji se sintetiše od nativne forme vitamina D koja je prisutna u provitaminskoj formi u našem organizmu. 


\subsubsection{Sinteza i metabolizam vitamina $D$}

Vitamin D je prisutan u humanom organizmu u provitaminskoj formi, 7-dehidroholesterol (7-dehidroholekalciferol), u ćelijama bazalnog sloja kože. Sinteza metabolički aktivne forme, kalcitriola, predstavlja višestepeni kompleksan fotohemijski proces (Slika 4.).

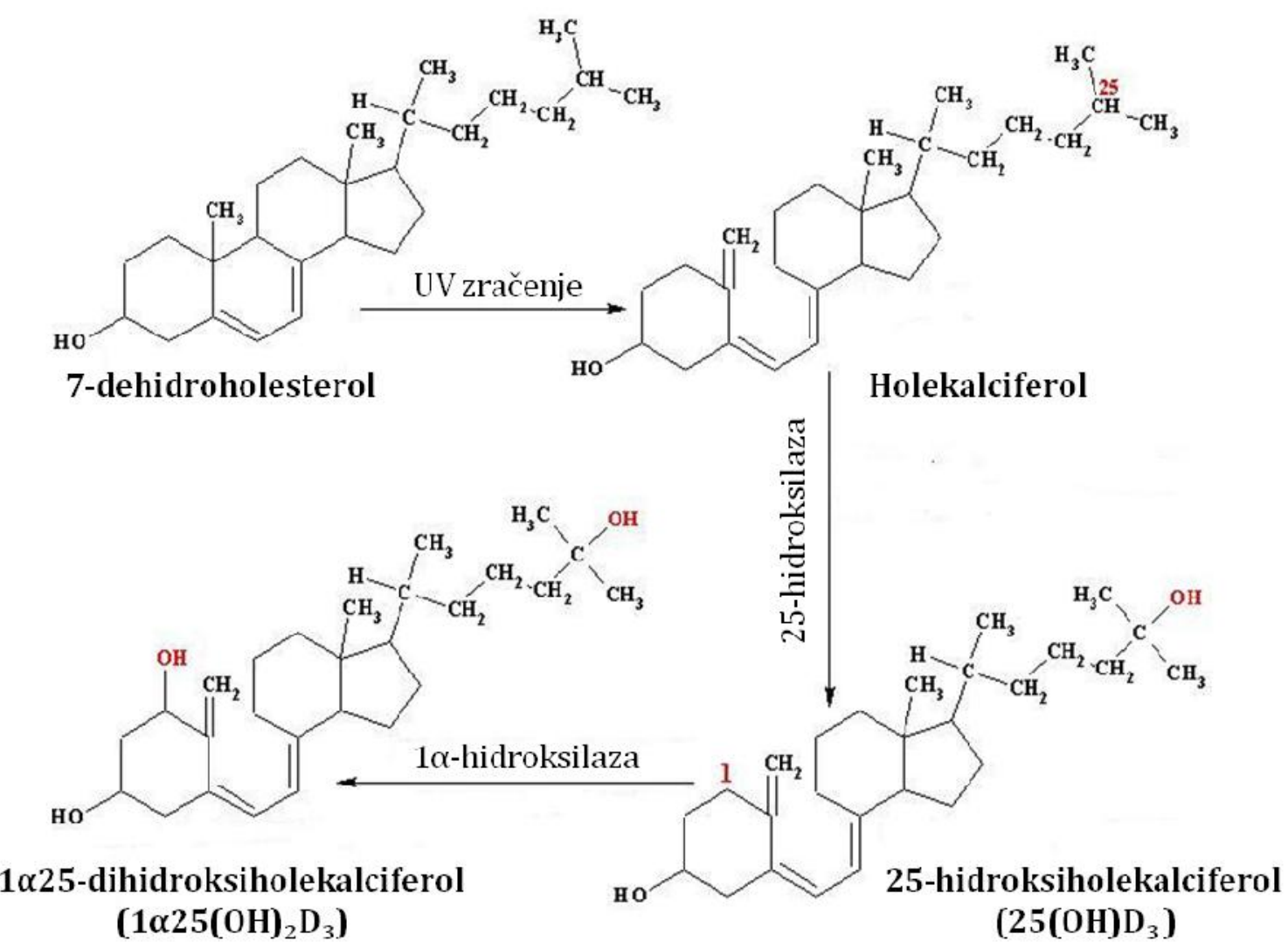

Slika 4. Fotohemijski proces sinteze aktivne forme vitamina D od 7-dehidroholesterola

Kao što je rečeno u prethodnom poglavlju, vitamin $D_{3}$ se može unositi $u$ organizam i ishranom namirnicama koje sadrže vitamin D (jaja, riba, namirnice obogaćene vitaminom D) (Slika 5.). Smanjeno Sunčevo zračenje predstavlja bitan ograničavajući faktor za sintezu vitamina D. Pod dejstvom Sunčeve svetlosti, B prsten 7-dehidroholesterola se otvara, te tako dobijen pre-vitamin $\mathrm{D}_{3}$ izomerizuje do vitamina $\mathrm{D}_{3}$ termo-senzitivnim procesom, ali ne katalitičkim procesom. 
Pokazano je da je formiranje pre-vitamina $\mathrm{D}_{3}$ relativno brzo i da dostiže maksimum tokom nekoliko sati (Bikle, 2009). Međutim, prilikom dužeg vremenskog izlaganja Sunčevom zračenju pre-vitamin $\mathrm{D}_{3}$ se konvertuje do biološki neaktivne forme lumisterola (Bikle, 2009).

Konformacione promene vitamina $D_{3}$, dobijenog izomerizacijom previtamina $D_{3}$, omogućuju vezivanje za vitamin $D$ vezujući protein i transport krvotokom do jetre (Slika 5.). U mitohondrijama jetre se holekalciferol hidroksiluje pomoću enzima 25-hidroksilaze (25(OH)-aza, kodiran genom CYP27A1), koja dodaje $\mathrm{OH}$ grupu na 25-i ugljenikov atom, čime nastaje 25-hidroksiholekalciferol $\left(25(\mathrm{OH}) \mathrm{D}_{3}\right)$, poznatiji kao kalcidiol. Regulacija 25-hidroksilacije vitamina D je slabo regulisana i nivo porasta $25(\mathrm{OH}) \mathrm{D}_{3}$ je u proporciji sa količinom uzimanja vitamina $\mathrm{D}$, zbog čega se upravo nivo $25(\mathrm{OH}) \mathrm{D}_{3}$ u plazmi koristi kao pokazatelj statusa vitamina D. Tako nastali 25-hidroksiholekalciferol, koji je glavna cirkulišuća forma vitamina $\mathrm{D}$, se u mitohondrijama proksimalnih tubula bubrega dalje hidroksiluje pomoću enzima 1 $\alpha$-hidroksilaze $(1 \alpha(\mathrm{OH})$-aza, kodiran genom CYP27B1), dodavanjem $\mathrm{OH}$ grupe na $1 \alpha$ ugljenikov atom, što rezultira konačniim stvaranjem aktivnog sekosteroida $1 \alpha 25$-dihidroksiholekalciferola, $1 \alpha 25(\mathrm{OH})_{2} \mathrm{D}_{3}$, poznatijeg kao kalcitriol, koji ima biološku aktivnost (Slika 5.). Proces $1 \alpha$-hidroksilacije $25(\mathrm{OH}) \mathrm{D}_{3} \mathrm{u}$ bubregu je visoko regulisan i sinteza kalcitriola je stimulisana paratireoidnim hormonom, dok je suprimirana visokim nivoom $\mathrm{Ca}^{2+}, \mathrm{P}$ i kalcitriola (Bikle, 2007). Iako su proksimalne tubule bubrega glavni izvor produkcije $1 \alpha 25(\mathrm{OH})_{2} \mathrm{D}_{3} \mathrm{u}$ telu, enzim $1 \alpha$-hidroksilaza je pronađen i u drugim ćelijama $\mathrm{i}$ tkivima, kao što su: imunske ćelije, epitelna i mnoga druga tkiva (Bikle, 2007), kosti i paratireoidna žlezda (Bikle, 2009), prostata, kolon, dojka, pluća, $\beta$-ćelije pankreasa, monociti (Dusso i sar., 2005). Takvi nalazi su ukazivali na mnogobrojne potencijalne uloge koje vitamin $\mathrm{D}$ može imati, pored uloge u regulaciji transporta $\mathrm{P}+\mathrm{i} \mathrm{Ca}{ }^{2+}$ i mineralizacije kostiju. 


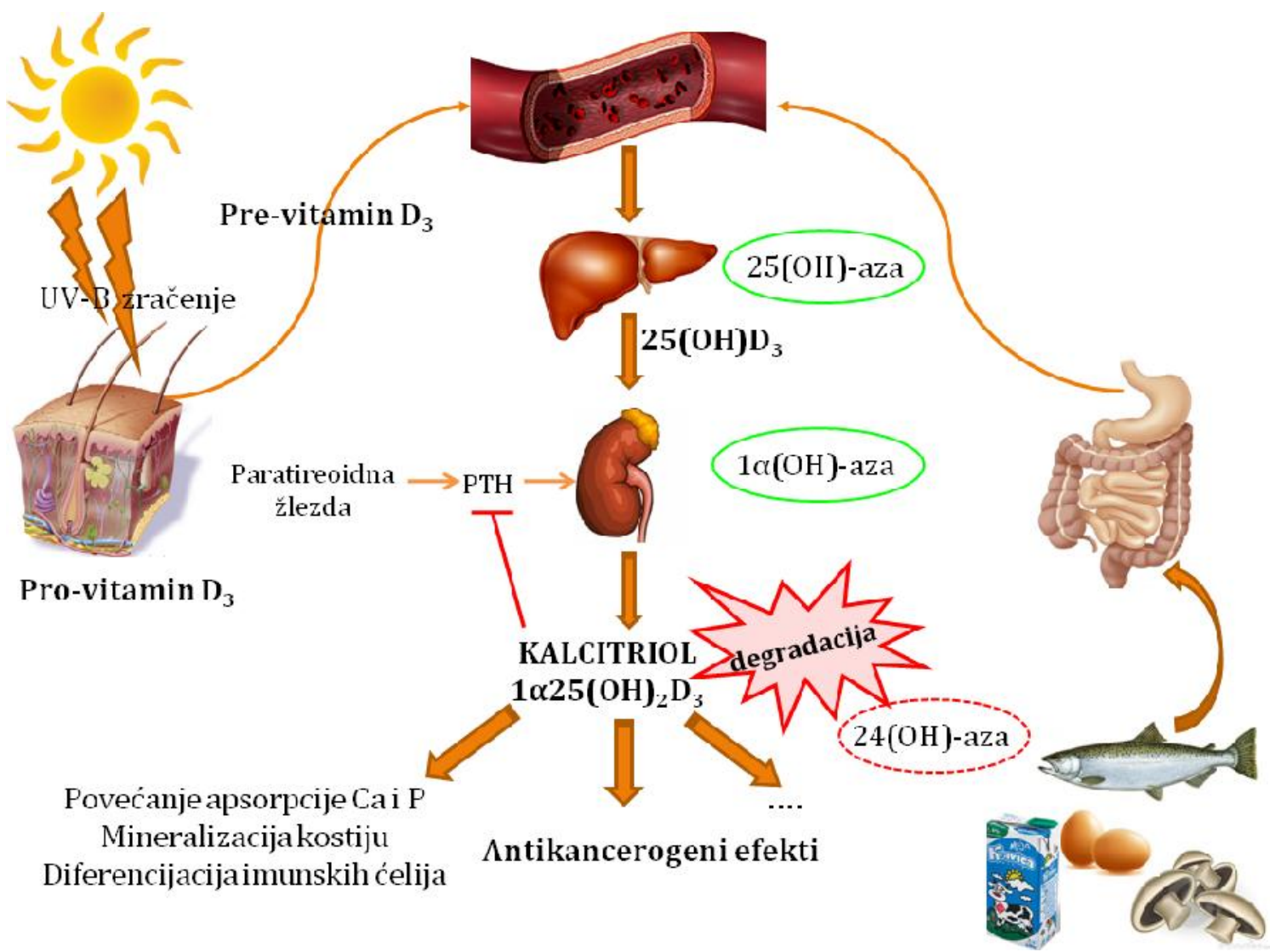

Slika 5. Šematski prikaz metabolizma vitamina D

Ograničavajući korak u anabolizmu i biološkoj aktivnosti kalcitriola predstavlja 24-hidroksilacija $25(\mathrm{OH}) \mathrm{D}_{3}$ i $1 \alpha 25(\mathrm{OH})_{2} \mathrm{D}_{3}$ enzimom 24-hidroksilazom (24(OH)-aza, kodirana CYP24A1 genom) do metabolita 24,25(OH) ${ }_{2} \mathrm{D}_{3}$ i $1 \alpha 24,25(\mathrm{OH})_{3} \mathrm{D}_{3} .1 \alpha 24,25(\mathrm{OH})_{3} \mathrm{D}_{3}$ je deset puta manje aktivan u poređenju sa $1 \alpha 25(\mathrm{OH})_{2} \mathrm{D}_{3}$, čija dalja oksidacija vodi progresivnom gubitku biološke aktivnosti i produkcije hidrofilnih kalcitroičnih kiselina koje će biti ekskretovane (Lin i White, 2003; Vuolo i sar.,2012). Miševi kojima nedostaje funkcionalan gen koji kodira 24-hidroksilazu imaju visok nivo $1 \alpha 25(\mathrm{OH})_{2} \mathrm{D}_{3} \mathrm{u}$ serumu, s obzirom na smanjenu mogućnost da ga degraduju (Dusso i sar., 2005). Aktivnost 24-hidroksilaze je regulisana recipročno $\mathrm{u}$ odnosu na $1 \alpha$-hidroksilazu, tako što se aktivnost $\mathrm{i}$ ekspresija povećavaju fosfatom, a smanjuju paratireoidnim hormonom (PTH). Koncentracija kalcitriola je regulisana povratnom spregom, gde povećanje $24,25(\mathrm{OH})_{2} \mathrm{D}_{3}$ indukuje sintezu kalcitriola $1 \alpha 25(\mathrm{OH})_{2} \mathrm{D}_{3}$, dok $\mathrm{Ca}^{2+}, \mathrm{P}^{+}$i sam kalcitriol suprimiraju sintezu. Biološka aktivnost metabolički aktivne forme 
vitamina D i njegovih analoga je u korelaciji sa koncentracijom slobodnog vitamina (Maruyama i sar., 2006).

S obzirom da se sinteza vitamina D u koži odvija pod uticajem Sunčevog zračenja, količina glavne cirkulišuće forme $25(\mathrm{OH}) \mathrm{D}_{3}$ u serumu pokazuje sezonsko variranje, pri čemu je najviša koncentracija tokom leta, a najniža tokom zime i ranog proleća (Berry i Hypponen, 2011). Na koncentraciju 25(OH) $\mathrm{D}_{3}$ utiču i geografska širina, deo dana i klima. Takođe, efikasnija sinteza vitamina D je zapažena kod osoba svetlije puti, što se smatra adaptacijom i posledicom migracije tokom evolucije iz sunčanih južnih regiona u severne krajeve sa slabijim Sunčevim zračenjem (Berry i Hypponen, 2011). Pored toga, status vitamina D je u vezi sa ishranom, količinom masnog tkiva i fizičkom aktivnošću. Primećeno je da postoji veza između redovne fizičke aktivnosti i višeg nivoa cirkulišuće forme vitamina D. Gojaznost je asocirana sa smanjenom količinom 25(OH)D 3 (Davis, 2009; Lagunova i sar., 2009). Naime, gojazne osobe imaju viši sadržaj masti koje predstavljaju rezervoar liposolubilnog vitamina D. Oslobađanje vitamina D iz masti se odvija relativno sporo, što zapravo predstavlja biološki mehanizam kojim se organizam štiti od toksičnih efekata aktivne forme vitamina $\mathrm{D}$, zadržavajući optimalni nivo $\mathrm{u}$ krvi (Lagunova i sar., 2009). Takođe je primećeno da je veza između statusa vitamina $\mathrm{D}$, gojaznosti i fizičke aktivnosti bila jača kod belaca u odnosu na Afro Amerikance (Davis, 2009). Faktori koji imaju veze sa sunčanjem (ultravioletno zračenje, sezona, vreme provedeno napolju, geografska širina), ishrana i druge karakteristike (godine, gojaznost, rasa, pušački status, alkohol) doprinose oko 20 $40 \%$ na variranje nivoa cirkulišuće forme $25(\mathrm{OH}) \mathrm{D}_{3}$ (Signorello i sar., 2011).

Metabolizam vitamina D može biti modifikovan mnogim faktorima ishrane (kalcijum, soja, folati) (Davis, 2009). Na primer, postoje dokazi da genistein, važna bioaktivna komponenta soje inhibira aktivnost $24(\mathrm{OH})$-aze, čime se povećava produkcija i poluživot kalcitriola u serumu. Korišćenje folata u ishrani takođe može dovesti do inhibiranja aktivnosti $24(\mathrm{OH})$-aze, kao posledica povećane metilacije promotorskog regiona i samim tim smanjene ekspresije CYP24A1 gena. 


\subsubsection{Transport vitamina $D$}

S obzirom da su metaboliti vitamina D lipofilni molekuli, slabo rastvorljivi u vodi, dalji transport cirkulacijom se odvija zahvaljujući vezivanju za proteine plazme. U tom smislu je najvažniji vitamin $\mathrm{D}$ vezujući protein (engl. Vitamin $\underline{\mathrm{D}}$ Binding Protein- BDP) koji vezuje metabolite vitamina D sledećim afinitetom (Dusso i sar., 2005):

$$
25(\mathrm{OH}) \mathrm{D}_{3}=24,25(\mathrm{OH})_{2} \mathrm{D}_{3}>1 \alpha 25(\mathrm{OH})_{2} \mathrm{D}_{3}>\text { vitamin D }
$$

Nivo BDP-a u plazmi je dvadeset puta viši nego ukupna količina metabolita vitamina D, tako da se preko $99 \%$ metabolita vezuje upravo za ovaj protein i transportuje cirkulacijom (Dusso i sar., 2005; Kochupillai, 2008).

Metaboliti vitamina D vezani za DBP imaju ograničeni pristup ciljnim ćelijama i stoga su manje podložni hepatičnom metabolizmu i ekskreciji, što njihov cirkulišući poluživot čini dužim. DBP praktično ima ulogu i u zaštiti od intoksikacije vitaminom D. Nivo DBP-a nije regulisan vitaminom D, ali se smanjuje u slučaju bolesti jetre, nefrotičnih sindroma i pothranjenosti, dok se tokom trudnoće povećava i usled korišćenja estrogenske terapije (Dusso i sar., 2005). Ipak, koncentracija $1 \alpha 25(\mathrm{OH})_{2} \mathrm{D}_{3}$ ostaje konstantna i usled promenjene količine DBP-a. Raniji dokazi su sugerisali da samo mala frakcija nevezanih metabolita pasivno prolazi i ulazi u ciljne ćelije gde se dalje metabolišu ili ispoljavaju svoju biološku aktivnost. Danas je poznato da $25(\mathrm{OH}) \mathrm{D}_{3}$ ne ulazi prostom difuzijom $\mathrm{u}$ ćelije proksimalnih tubula bubrega koje sadrže $1 \alpha$-hidroksilazu, već je ulazak posredovan DBP receptorom. Megalin je deo kompleksa proteina koji ima ulogu u olakšanoj endocitozi (Slika 6.). 


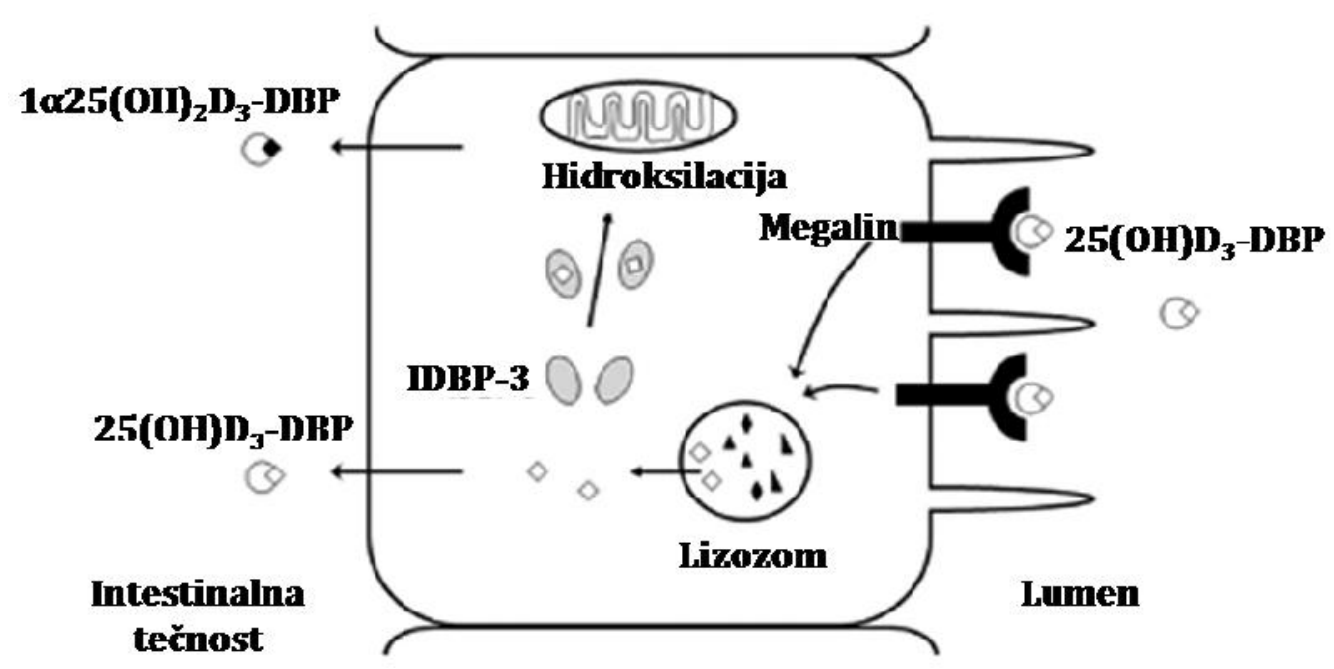

Slika 6. Ulazak $25(\mathrm{OH}) \mathrm{D}_{3}$ u proksimalne tubule bubrega posredstvom receptora megalina (preuzeto: Dusso i sar., 2005, modifikovano)

Po ulasku u ćeliju DBP se degraduje, oslobađajući $25(\mathrm{OH}) \mathrm{D}_{3}$ za dalju

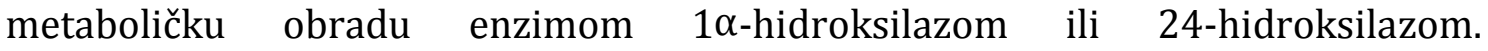
Translokacija $25(\mathrm{OH}) \mathrm{D}_{3}$ u mitohondrije predstavlja olakšan, pre nego pasivan mehanizam. $\mathrm{COOH}$ terminus megalina interaguje sa bar dva intracelularna vitamin D vezujuća proteina (engl. Intracellular Vitamin D $\underline{B}$ inding Proteins-IDBP) IDBP-1 i IDBP-3. Zapravo IDBP-3 interaguje direktno sa $1 \alpha$-hidroksilazom. Prekomerna ekspresija IDBP-3 u ćelijama koje eksprimiraju megalin povećava ulazak $25(\mathrm{OH}) \mathrm{D}_{3}$ u mitohondrije, gde se vrši hidroksilacija.

\subsubsection{Intracelularni signalni putevi vitamina D}

Steroidni hormoni imaju ulogu hemijskih glasnika u velikom broju vrsta i ciljnih tkiva za prenošenje signala koji rezultuju generisanjem brzih genomskih odgovora. Sposobnost steroidnih hormona, uključujući i vitamin D da generiše biološke odgovore je određena prisustvom njihovih receptora u određenim ciljnim organima i tkivima (Norman, 2006). Kalcitriol je konformaciono fleksibilan molekul koji učestvuje u stimulaciji brze intestinalne apsorpcije $\mathrm{Ca}^{2+}$, sekrecije insulina u $\beta$-ćelijama pankreasa, otvaranje jonsko zavisnih kanala za kalcijum u 
osteoblastima, brze migracije endoteliajalnih ćelija i mnoge druge (Norman, 2006). Klasični signalni put vitamina D se odvija, kao i za sve steroidne molekule, preko

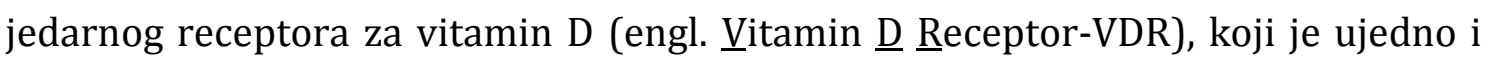
transkripcioni faktor. Postoji takođe i veliki broj dokaza za učešće citoplazmatskih puteva u koje su uključeni citoplazmatski i membranski receptori koji su nezavisni od jedarnog VDR receptora. Stimulacija ovih puteva rezultira post-translacionim efektima, koji se brzo dešavaju, tokom nekoliko minuta, ali takođe mogu imati i genomske efekte, koji se ostvaruju nakon nekoliko sati ili dana (Osborne i Hutchinson, 2002).

\subsubsection{Biološke funkcije vitamina $D$}

Biološke funkcije vitamina $\mathrm{D}$ se mogu podeliti u dve grupe: klasične i neklasične. Pored toga što je od davnina poznato da vitamin $\mathrm{D}$ ima ulogu $\mathrm{u}$ regulaciji metabolizma kalcijuma i fosfata, što bi predstavljalo klasičnu funkciju, još od 1980. godine je poznato da metabolički aktivna forma vitamina D ima potencijalno antiproliferativno dejstvo i uticaj na diferencijaciju ćelija. Naime, 1981. godine je pokazano da $1 \alpha 25(\mathrm{OH})_{2} \mathrm{D}_{3}$ u nanomolarnoj koncentraciji inhibira klonalnu proliferaciju humanih ćelijskih linija leukemije i podstiče diferencijaciju normalnih i mijeloidnih prekursora prema zrelijim, manje agresivnim fenotipovima (Thorne i Campbell, 2008). Ovim rezultatima je pokazano da $1 \alpha 25(\mathrm{OH})_{2} \mathrm{D}_{3}$ može biti potencijalno koristan za tretman leukemija i drugih mijeloproliferativnih bolesti. Antineoplastična aktivnost $1 \alpha 25(\mathrm{OH})_{2} \mathrm{D}_{3}$ je pokazana i u in vitro i in vivo studijama na raznim malignim ćelijskim tipovima razvijenih od različitih tkiva, kao što su leukemije, kolon, prostata, dojka (Bouillon i sar., 2008). Mehanizmi koji leže u osnovi ovog procesa nisu u potpunosti rasvetljeni, ali je pokazano da se smanjenje ćelijskog rasta odvija preko brojnih ćelijskih puteva, uključujući zaustavljanje ćelijskog ciklusa, indukciju apoptoze i izmenjenu aktivaciju signalizacije fakora rasta (Deeb i sar., 2007; Cui i Rohan, 2006). Neklasične funkcije vitamina D su predstavljene na Slici 7. Efekat vitamina D na apoptozu, invaziju malignih ćelija, metastazu i angiogenezu se intenzivno proučava 
(Osborne i Hutchinson, 2002). Indukcija programirane ćelijske smrti doprinosi antineoplastičnoj aktivnosti kalcitriola, ali i inhibicija angiogeneze i invazivnosti mogu doprineti antitumorskoj aktivnosti (Ali i Vaidya, 2008). Protektivna uloga vitamina D u nastanku kancera je potvrđena postojanjem asocijacija između pojave kancera prostate, dojke, kolorektalnog kancera i deficijencije vitamina D.

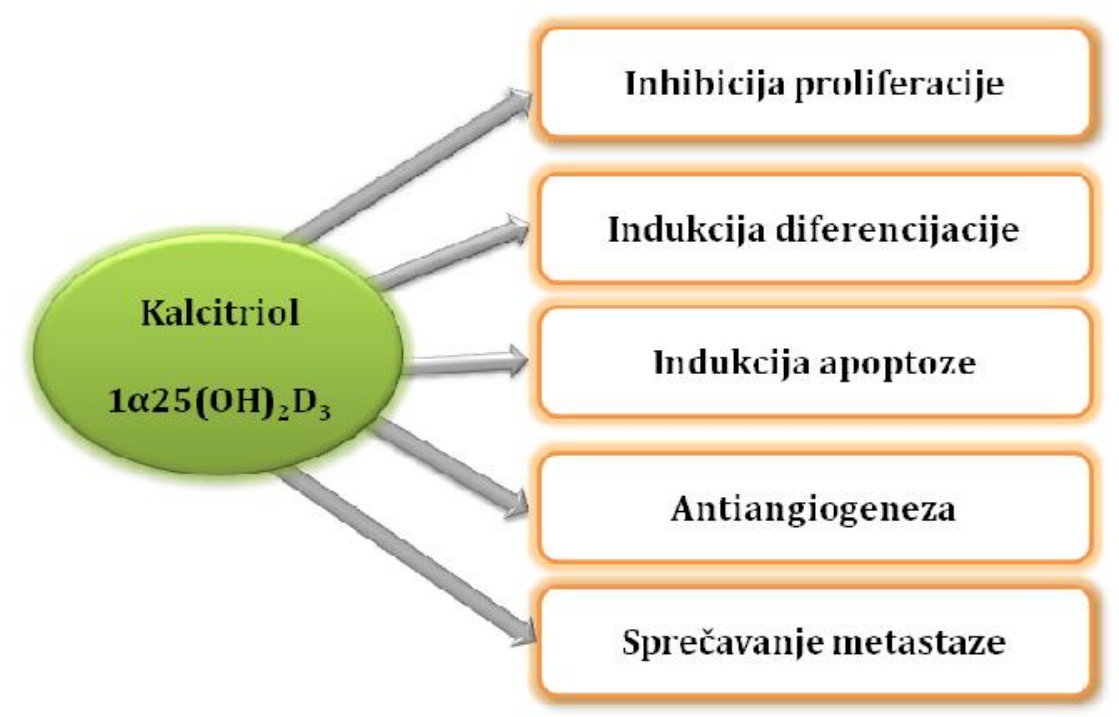

Slika 7. Neklasične funkcije metabolički aktivne forme vitamina D-kalcitriola

U predstojećem tekstu će biti prikazani samo neklasični vidovi aktivnosti metabolički aktivne forme vitamina D i to molekularni mehanizmi kojima vitamin D utiče na ćelijski rast, invaziju malignih ćelija, indukciju apoptoze i inhibiciju angiogeneze .

\subsubsection{1. Ćelijska proliferacija}

Kalcitriol, $1 \alpha 25(\mathrm{OH})_{2} \mathrm{D}_{3}$, utiče na proliferaciju i diferencijaciju brojnih ćelijskih tipova koji eksprimiraju receptor za vitamin D. Efekat $1 \alpha 25(\mathrm{OH})_{2} \mathrm{D}_{3}$ na ćelijski ciklus je pokazan na malignim ćelijama u kulturi in vitro i u in vivo modelu skvamocelularnih karcinoma (Nagpal i sar., 2005). Centralni efekat na proliferaciju vitamin D ostvaruje u G1/S kontrolnoj tački ćelijskog ciklusa (Slika 8.). Generalno je prihvaćeno stanovište da velika većina kancera poseduje aberacije upravo u 
ovoj kontrolnoj tački. Kada se ćelija nalazi u G1 fazi, G1/S kontrolna tačka je blokirana nefosforilisanom formom proteina retinoblastoma $(\mathrm{Rb})$, koji vezuje i inaktivira transkripcione faktore, npr. E2F (Slika 9.). Transkripcioni faktor E2F je esencijalan za sintezu DNK u S fazi i neophodan je za regulaciju proteina potrebnih za progresiju iz G1 u S fazu ćelijskog ciklusa. Fosforilacija Rb proteina ciklin zavisnom kinazom 4 (CDK4), CDK6 ili CDK2 uklanja inhibitorni efekat i oslobađa transkripcione faktore (Slika 8., Slika 9.). Ciklin zavisne kinaze se aktiviraju jedna po jedna ciklinima i to ciklinom D i E. CDK su inhibirane sa dve klase CDK inhibitora (p15, p16) koji odvajaju ciklin od ciklin-CDK kompleksa i cip-kip proteina (npr. p27, p21), koji zarobljavaju ćeliju u G1 fazi. Kombinovanim delovanjem ovih „čuvara“ ćelijskog ciklusa, proliferacija ćelija kancera je onemogućena. $1 \alpha 25(\mathrm{OH})_{2} \mathrm{D}_{3}$ indukuje gensku transkripciju inhibitora ciklin zavisnih kinaza p21 (WAF1/CIP1), što se smatra dovoljnim za zaustavljanje rasta i podsticanje diferencijacije (Slika 10.). Pretpostavlja se da vitamin D može direktno stimulisati transkripcionu aktivnost p21, s obzirom da su u genu koji kodira za p21 CDK inhibitor identifikovani VDRE elementi (Liu i sar., 1996). Pored toga, kalcitriol indukuje sintezu i/ili stabilizaciju inhibitora ciklin zavisne kinaze p27 (KIP1) (Lamprecht i Lipkin, 2003; Ylikomi i sar., 2002; Jensen i sar., 2001; Hansen i sar., 2001). Povišen nivo p27 je zabeležen u slučaju ćelija karcinoma glave i vrata koje su tretirane kalcitriolom (Lin i White, 2003). Od svih regulatora ćelijskog ciklusa, samo za p21 je pokazano da podleže efektu kalcitirola in vivo. Naime, nakon davanja kalcitriola tokom tri dana miševima sa skvamocelularnim karcinomom, uočena je značajna redukcija veličine tumora, što je bilo u vezi sa povećanjem nivoa p21 (Hershberger i sar., 2000).

Takođe, pokazano je da kalcipotriol, analog kalcitriola povećava ekspresiju p21 u normalnoj ljudskoj koži (Deeb i sar., 2007). S obzirom da je uticaj vitamina D na ćelijski ciklus posredovan $\mathrm{Rb}$ proteinom, povišena ekspresija ili hiperfosforilacija Rb proteina može uticati na efekat vitamina D (Lou i sar., 2004; Ylikomi i sar., 2002). Pored toga, glavna cirkulišuća forma vitamina $D, 25(\mathrm{OH}) \mathrm{D}_{3}, \mathrm{u}$ koncentraciji koja je niska da aktivira receptor za vitamin $\mathrm{D}$, može zaustaviti rast ćelijama koje eksprimiraju $1 \alpha$-hidroksilazu. Kalcitriol takođe vrši negativnu 
kontrolu ekspresije ciklina D, ključnog regulatora ćelijskog ciklusa, čija je ekspresija često značajno povišena u tumoru kolona (Lamprecht i Lipkin, 2003).

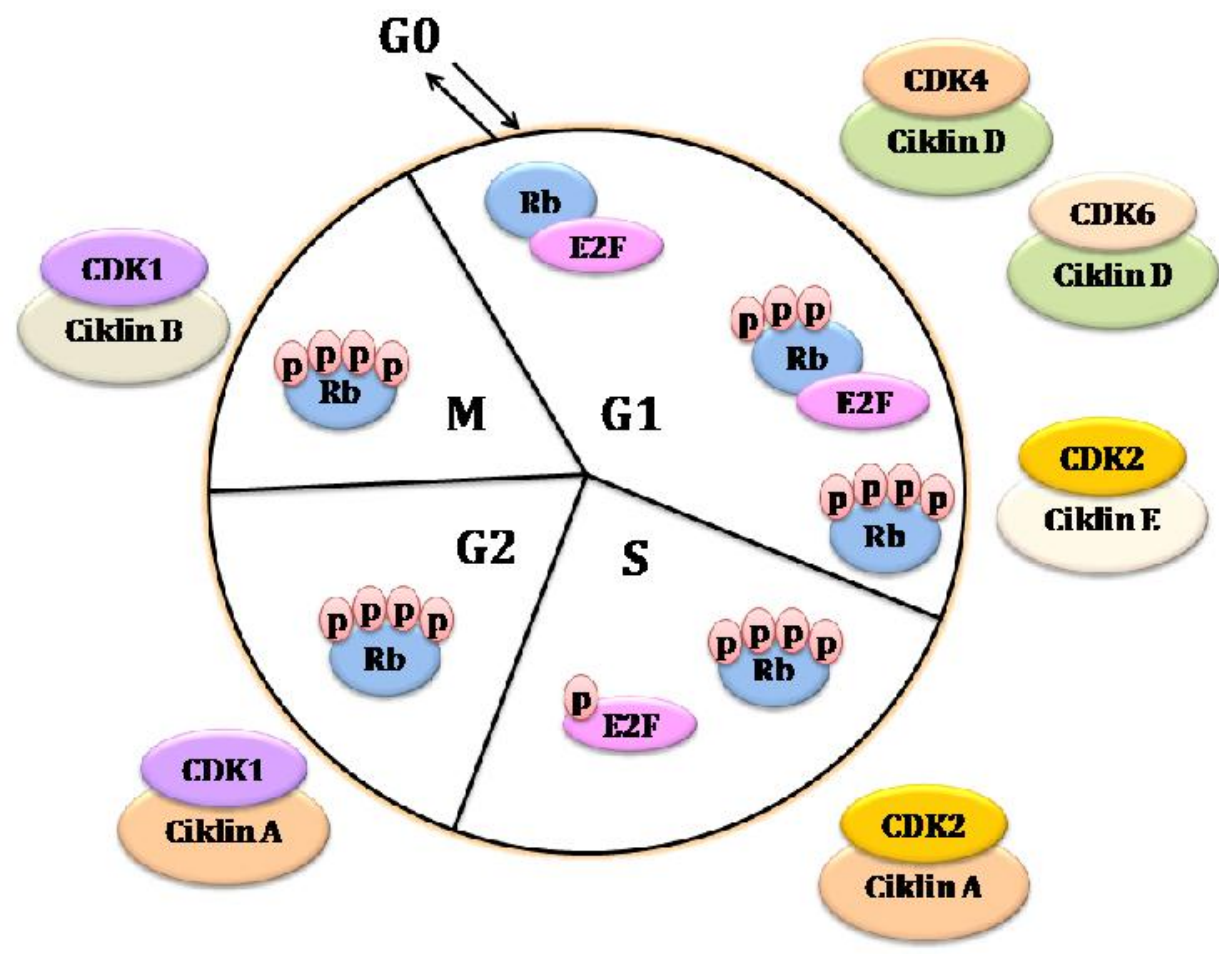

Slika 8. Faze i regulacija progresije ćelijskog ciklusa

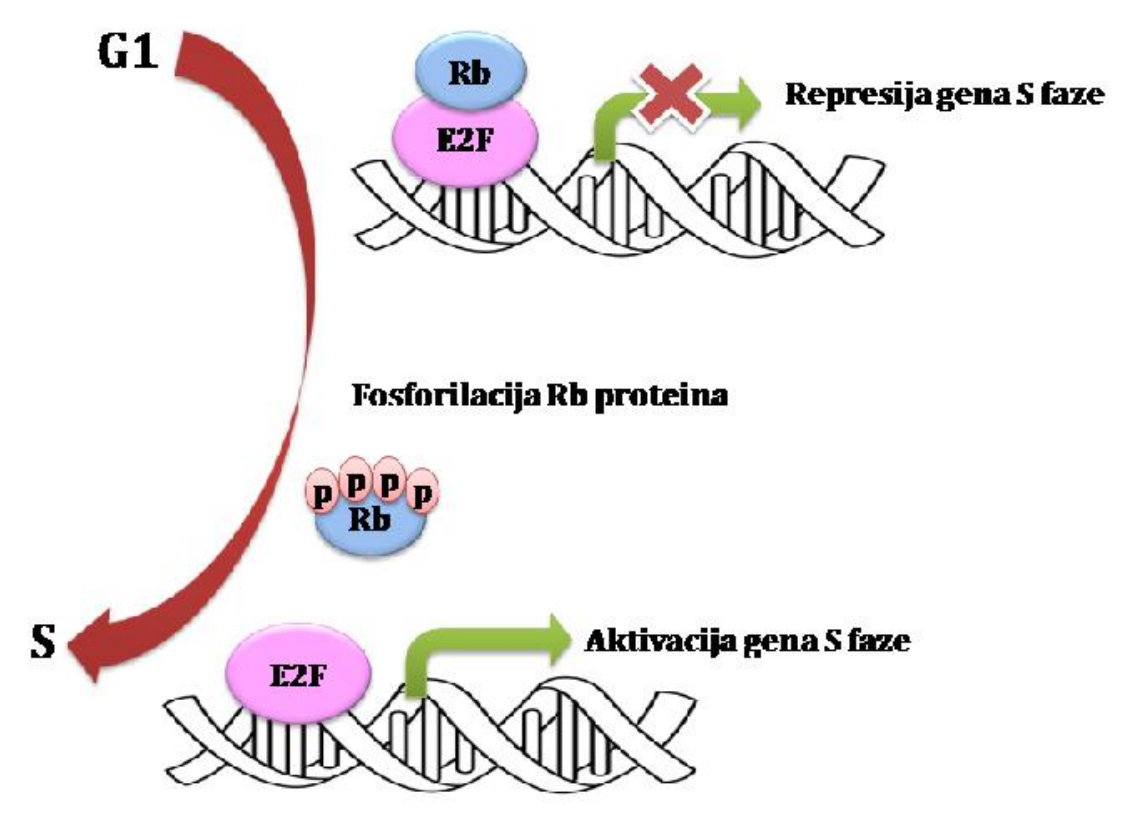

Slika 9. Pojednostavljeni prikaz regulacije G1/S kontrolne tačke ćelijskog ciklusa 


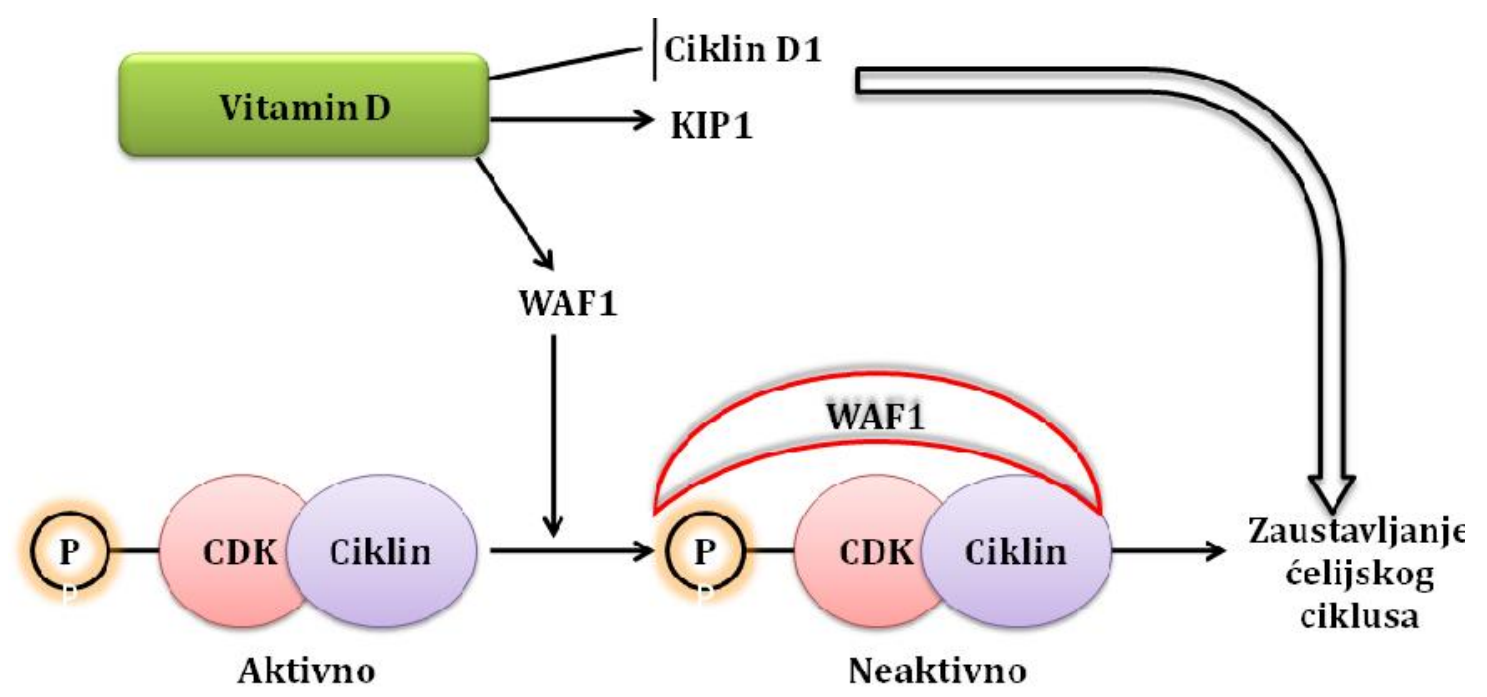

Slika 10. Inhibitorni efekat vitamina D na ćelijski ciklus (slika rađena po uzoru na Lamprecht i Lipkin, 2003).

Sumirano, vitamin D ima inhibitorni efekat na G1/S kontrolnu tačku i može potpuno zaustaviti ćelijski ciklus u toj tački multiplim mehanizmima (Carlberg i Seuter, 2009; Stewart i Weigel, 2004). Glavni efekat $1 \alpha 25(\mathrm{OH})_{2} \mathrm{D}_{3}$ je regulacija inhibitora CDK i regulacija aktivatora. Kada su različiti tipovi ćelija kancera izloženi vitaminu $\mathrm{D}$, dolazi do smanjenja broja ćelija koje se nalaze u S fazi, praćeno akumulacijom velikog broj ćelija u G0-G1 fazi. Količina ćelija koje se nalaze u G2 fazi ili fazama mitoze se ne menja usled tretmana vitaminom D (Hansen i sar., 2001). Kalcitriol može imati indirektni efekat na regulaciju ćelijskog ciklusa. Tako na primer $1 \alpha 25(\mathrm{OH})_{2} \mathrm{D}_{3}$ dovodi do povećanja ekspresije IGFBP3 gena (engl. Insuline Like Growth Factor $\underline{B}$ inding Protein $\underline{3}$ ) i transformisanja TGF $\beta$-SMAD3 signalne kaskade, što dovodi do inhibicije proliferacije epitelijalnih ćelija (Deeb i sar., 2007; Lamprecht i Lipkin, 2003). U LNCaP ćelijskim linijama kancera prostate, IGFBP3 je neophodna komponenta koja zajedno sa kalcitriolom indukuje zaustavljanje ćelijskog ciklusa povećanjem ekspresije p21/WAF1 (Lou i sar., 2004).

Iako je u prethodnom tekstu dat pregled načina na koji kalcitriol vrši inhibiciju proliferacije, smatra se da se precizni molekularni mehanizmi antiproliferativnog dejstva kalcitriola razlikuju od jednog do drugog tumorskog tipa. 


\subsubsection{Diferencijacija}

Da li je indukcija ćelijske diferencijacije vitaminom D posledica blokiranja progresije ćelijskog ciklusa ili je obrnuto, predmet je mnogobrojnih rasprava. Istovremeno se postavlja pitanje da li se ova dva procesa uopšte mogu razdvojiti ili su čak potpuno nezavisni. Prema jednom stanovištu, diferencijacija je očigledno povezana sa ćelijskim ciklusom i asocirana sa usporavanjem ćelijskog ciklusa, npr. povišenom ekspresijom p21, koji ima inhibitorni efekat na ćelijsku proliferaciju, što samim tim može podsticati diferencijaciju. Međutim, neki smatraju da antiproliferativni i prodiferencirajući efekti $1 \alpha 25(\mathrm{OH})_{2} \mathrm{D}_{3}$ nisu povezani, te da manje koncentracije kalcitriola, koje su dovoljne da indukuju diferencijaciju ćelija, istovremeno mogu indukovati proliferaciju, pre nego da je inhibiraju (Osborne i Hutchinson, 2002).

Bez obzira na stavove, veliki je broj dokaza koji govore da je vitamin D povezan sa indukcijom procesa diferencijacije. U normalnim ćelijama, $1 \alpha 25(\mathrm{OH})_{2} \mathrm{D}_{3}$ podstiče diferencijaciju keratinocita od epidermalnih prekursora (Reichrath i sar., 1999), monocita-makrofaga od mijeloidnih progenitora i osteoklasta od mononukleusnih prekursora (Osborne i Hutchinson, 2002). Studije genske ekspresije u ćelijama kancera, microarray metodom, su pokazale da kalcitriol deluje na maligne ćelije karcinoma glave i vrata, kolona i prostate inicirajući diferencijaciju (Lin i White, 2003; Deeb i sar., 2007). Ćelije karcinoma glave i vrata, tretirane analogom kalcitriola, EB1089, su pokazivale povišenu ekspresiju nekoliko gena koji su uključeni u proces ćelijske diferencijacije (cistatin M, proteaza M, kolagen tip 13, dezmoglein 3) (Lin i White, 2003). U ćelijama kancera dojke, tretiranim vitaminom $\mathrm{D}$ u in vitro uslovima, uočeno je povećanje apolipoproteina D, za koji se smatra da je povezan sa stepenom diferencijacije i kliničkim ishodom karcinoma dojke kod žena (Lopez-Boado i sar., 1997). Povećanje sekrecije markera diferencijacije, specifičnog antigena prostate, je registrovano nakon izlaganja ćelija kancera prostate kalcitriolu (Hansen i sar., 2001). 


\subsubsection{Apoptoza}

Pored antiproliferativnog efekta, sve je veći broj dokaza da kalcitriol ispoljava antitumorske efekte regulacijom ključnih medijatora apoptoze i to represijom ekspresije antiapoptotskih proteina ili indukujući ekspresiju proapoptotskih proteina. Indukcija apoptoze nakon tretmana vitaminom D je pokazana u slučaju kancera dojke, kolona, prostate, kao i melanoma, mijeloma i glioblastoma (Hansen i sar., 2001). Tačan proces kojim $1 \alpha 25(\mathrm{OH})_{2} \mathrm{D}_{3}$ indukuje apoptozu je slabo okarakterisan, ali se pretpostavlja da je reč o višestrukom mehanizmu. Efekat može biti klasifikovan kao indirektni, preko efekta na faktore rasta ili citokine i njihove receptore, ili direktan, gde se efekat ostvaruje na molekule koji su deo signalnog puta, što rezultira apoptozom. Konačni zajednički signalni put apoptoze je kaskada kaspaza. Kaspaze su familija evoluciono konzerviranih cistein proteinaza, vitalnih citoskeletnih i jedarnih proteina. Put aktiviranja kaspaza može biti podeljen u dve glavne grupe: spoljašnji, koji uključuje receptore smrti i unutrašnji put koji uključuje mitohondrije.

Spoljašnji put pokretanja apoptoze aktivira receptore uništenja (ćelijske smrti) koji se nalaze na površini ćelije i koji će pokrenuti aktivaciju kaspaza (Slika 11.). Protein BID, član BCL-2 familije proteina, nakon isecanja od strane kaspaze 8 , se translocira u spoljašnju membranu mitohondrija i indukuje otpuštanje proapoptotskih faktora.

Dobro poznat mitohondrijalni sistem uključuje BCL-2 familiju, čiji su članovi i antiapoptotski (BCL-2 i BCL-X) i proapoptotski (BAX, BID, BAD) molekuli. Smatra se da se BAX i BAK proteini translociraju iz citoplazme u membranu mitohondrija, gde oligomerizuju. Efekti BAX i BAK proteina se ogledaju u otvaranju mitohondrijskih permeabilnih tranzicionih pora (PT), redukciji mitohondrijskog transmembranskog potencijala, gubitaku kalcijuma i stvaranju reaktivnih vrsta kiseonika. Posledično, dolazi do otpuštanja citohroma c u citosol, koji indukuje formiranje kompleksa APAF1 (engl. Apoptotic Protease Activating Factor $\underline{1}$ ) i prokaspaze 9 u molekularni kompleks apoptozom, što dovodi do stvaranja aktivne kaspaze 9. Kaspaza 9 aktivira kaspazu 3, što konačno vodi ćeliju u apoptozu. 
BCL-2 je inhibitor permeabilne PT pore u membrani mitohondrija. Postoji nekoliko potvrda da se povećanje odnosa BAX/BCL-2 od strane $1 \alpha 25(\mathrm{OH})_{2} \mathrm{D}_{3}$ ili njegovih analoga, može odvijati preko snižene ekspresije BCL-2 ili preko translokacije proapoptotskog proteina BAX u mitohondriju. Poznato je da sfingomijelin-ceramid-gangliozid GD3 signalni put indukuje apoptozu. Agonist ovog puta je $1 \alpha 25(\mathrm{OH})_{2} \mathrm{D}_{3}$. Neki podaci ukazuju da vitamin D snižava ekspresiju proteina članova IAP familije, koja je uključena u inhibiciju apoptoze. Takođe se razmatra mogućnost direktnog delovanja vitamina D na mitohondrije.

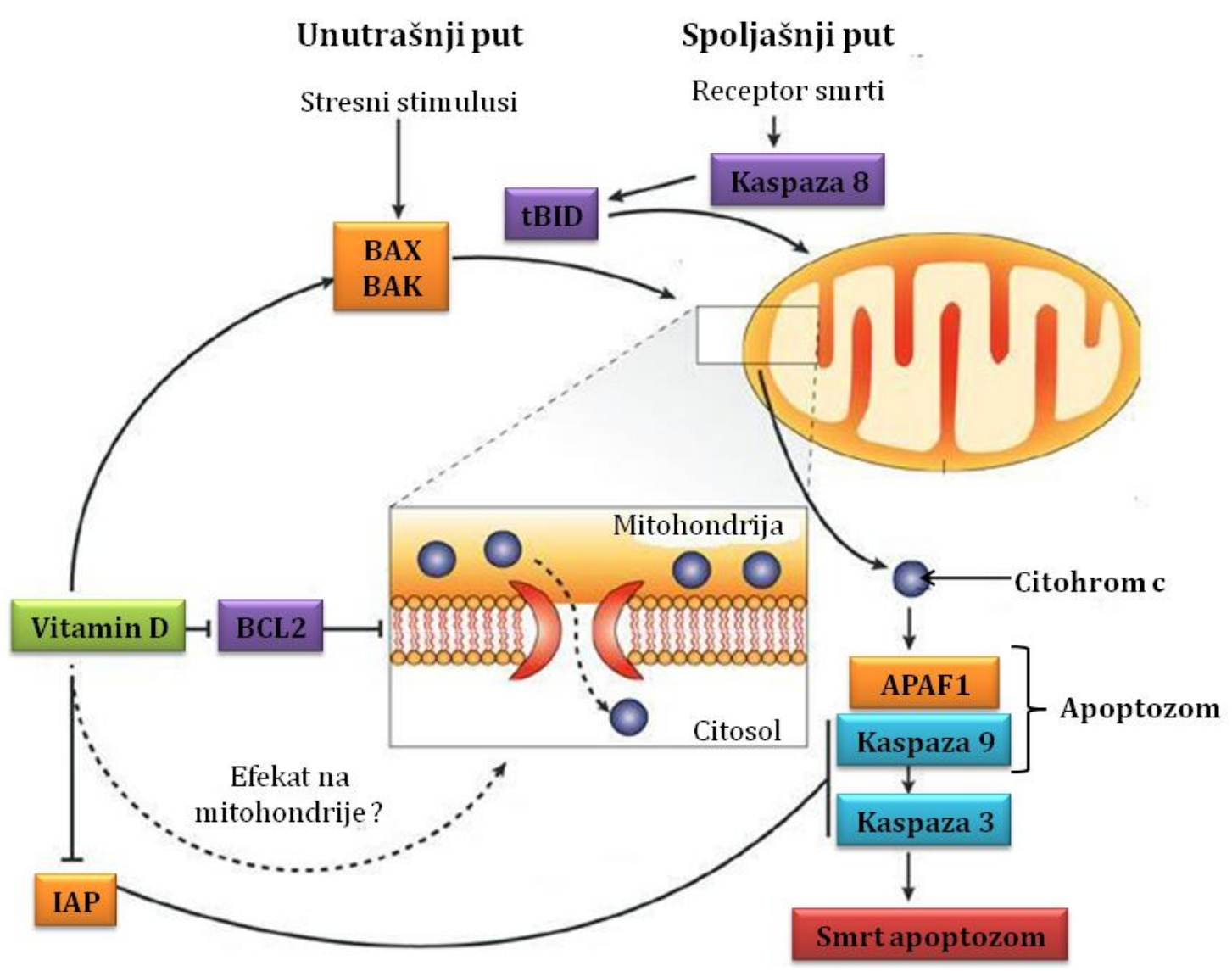

Slika 11. Proapoptotski efekat vitamina D (preuzeto: Lamprecht i Lipkin, 2003, modifikovano)

U ćelijama kancera dojke $1 \alpha 25(\mathrm{OH})_{2} \mathrm{D}_{3}$ indukuje apoptozu recipročnom modulacijom BCL-2 i BAX. Takođe povećava intracelularni kalcijum, koji aktivira kalcijum zavisne proapoptotske proteaze i kaspaze 12. Prema jednom od predloženih mehanizama, kalcitriolom posredovana apoptoza u epitelijalnom 
kanceru ovarijuma je povezana sa destabilizacijom iRNK telomeraze reverzne transkriptaze, čime se apoptoza praktično pokreće kao posledica snižene regulacije telomerazne aktivnosti (Jiang i sar., 2004; Deeb i sar., 2007). Sa druge strane, $1 \alpha 25(\mathrm{OH})_{2} \mathrm{D}_{3}$ štiti keratinocite od apoptoze indukovane UV zračenjem ili hemoterapijom. U normalnim tkivima proapoptotske osobine kalcitriola su ključne u kontroli hiperplastičnog rasta. Uzeto sve zajedno, ovi nalazi ukazuju da vitamin D ima proapoptotske i antiapoptotske efekte koji su važni u razvoju i funkciji normalnog tkiva, kao i indukciji zaustavljanja rasta u kancer i nekancerskim hiperproliferativnim bolestima.

\subsubsection{Invazija i metastaza malignih ćelija}

Invazija i metastaza malignih ćelija predstavljaju veliki klinički problem i glavni uzrok smrti pacijenata obolelih od kancera. Reč je o kompleksnim mehanizmima koji uključuju vezivanje tumorskih ćelija za komponente ekstracelularnog matriksa, degradaciju ekstracelularnog matriksa, kretanje tumorskih ćelija kroz degradiran prostor, indukciju angiogeneze i proteolitičkih enzima i njihovih inhibitora. Sposobnost tumorskih ćelija da invadiraju i metastaziraju zavisi od stepena diferencijacije, s obzirom da su slabo diferencirane ćelije invazivnije u poređenju sa ćelijama koje se nalaze na višem stupnju diferencijacije.

Bitna funkcija vitamina D je i sprečavanje invazije malignih ćelija. Pokazano je da tretman fiziološkim koncentracijama $1 \alpha 25(\mathrm{OH})_{2} \mathrm{D}_{3}$ inhibira invaziju brojnih malignih ćelijskih tipova, kao što su karcinomi prostate, dojke i pluća (Osborne i Hutchinson, 2002). $1 \alpha 25(\mathrm{OH})_{2} \mathrm{D}_{3}$ u ćelijama kancera prostate inhibira migraciju endotelnih ćelija (Deeb i sar., 2007). In vivo studijama je pokazano da uvođenje $1 \alpha 25(\mathrm{OH})_{2} \mathrm{D}_{3}$ inhibira invaziju malignih ćelija kod eksperimentalno indukovanog kancera bešike kod pacova (Konety i sar., 2001). Što se tiče mehanizma, pokazano je da $1 \alpha 25(\mathrm{OH})_{2} \mathrm{D}_{3}$ inhibira serin proteinaze, npr. komponente plazminogen aktivator sistema i određene matriks metaloproteinaze i njihove inhibitore koji imaju važnu ulogu u invaziji malignih ćelija. Smanjena ekspresija urokinaza PA i tipova tkiva PA i povećanje ekspresije PA inhibitora u odgovoru na $1 \alpha 25(\mathrm{OH})_{2} \mathrm{D}_{3}$ je 
pokazano u kancer ćelijama dojke, dok je registrovano smanjenje ekspresije MMP2 u kancer ćelijama prostate i MMP-9 u karcinomima dojke i prostate (Osborne i Hutchinson, 2002). Sprečavanje metastaze od strane $1 \alpha 25(\mathrm{OH})_{2} \mathrm{D}_{3}$ se može još objasniti anti-angiogenetskim efektima vitamina D.

Kao posledica tretmana analogom kalcitriola, EB1089, u ćelijama karcinoma glave i vrata je pokazana represija ekspresije nekoliko markera ćelijske progresije (N-kadherin, tumor antigen L6, tenascin-C) (Lin i White, 2003). Tenascin-C je ekstracelularni matriks protein sa invazivnim i angiogenetskim aktivnostima koji je aktiviran $\mathrm{u}$ mnogim ćelijskim tipovima tokom geneze tumora (Osborne $\mathrm{i}$ Hutchinson, 2002). Pokazano je da je transkripcija tenascin-C inhibirana kalcitriolom u brojnim normalnim, kao i malignim epitelnim humanim i mišjim ćelijskim linijama (Osborne i Hutchinson, 2002).

\subsubsection{Angiogeneza}

Jedna od osnovnih odlika tumorskog rasta je pojačano formiranje krvnih sudova, procesom koji se naziva angiogeneza. Kalcitriol takođe može inhibirati angiogenezu, čime se efekti vitamina D kao antikancerogenog faktora mogu zaokružiti u jednu celinu. In vitro studije su pokazale da $1 \alpha 25(\mathrm{OH})_{2} \mathrm{D}_{3}$ inhibira proliferaciju nekih tipova tumora poreklom od endotelnih ćelija i da istovremeno inhibira faktore rasta vaskularnog endotela čime se intenzitet angiogeneze smanjuje (Mantell i sar., 2000). In vivo studijama u imunosuprimiranim miševima, angiogeneza je indukovana intradermalnim injektiranjem humanih ćelijskih linija različitog porekla, a potom inhibirana kalcitriolom, koji je dostavljen sistematski i u životinje in vivo i u tumorske ćelije in vitro (Osborne i Hutchinson, 2002).

Pokazano je da $1 \alpha 25(\mathrm{OH})_{2} \mathrm{D}_{3}$ povećava nivo iRNK vaskularnog endotelnog faktora rasta (engl. Vascular Endotelial Growth Factor-VEGF) u glatkim vaskularnim mišićnim ćelijama i reguliše nivo iRNK anti-angiogenetskog faktora trombospondina $1 \mathrm{u}$ SW480-ADH humanim tumorskim ćelijama kolona (Deeb i sar., 2007). U ćelijama skvamocelularnih karcinoma, $1 \alpha 25(\mathrm{OH})_{2} \mathrm{D}_{3}$ indukuje sintezu angiogenetskog faktora IL-8, dok u ćelijama kancera prostate $1 \alpha 25(\mathrm{OH})_{2} \mathrm{D}_{3}$ prekida signalni put IL-8, čime inhibira migraciju endotelnih ćelija (Vuolo i sar., 
2012; Bao i sar., 2006). Značajna inhibicija metastaze je postignuta u modelima kancera prostate i pluća, tretiranih kalcitriolom i ovi efekti se mogu bar delimično pripisati anti angiogenetskom efektu.

\subsubsection{Povezanost geografske širine $\mathrm{i}$ vitamina $\mathrm{D}$ sa nastankom kancera}

Brojnim studijama je pokazano da je porast geografske širine, počev od ekvatora i smanjenje pigmentacije kože u značajnoj vezi sa povećanjem inicidence za pojavu različitih tipova kancera ili povećanjem agresivnosti kancera (Osborne i Hutchinson, 2002; Deeb i sar., 2007; Bouillon i sar., 2006). Ovakva veza se može objasniti smanjenom sintezom vitamina D usled smanjene izloženosti efektivnom Sunčevom zračenju, kao i korišćenju zaštite od Sunca. Incidenca kancera dojke je veća u zemljama koje su locirane na većim geografskim širinama (Aung i sar., 2009; Osborne i Hutchinson, 2002) i povećana je stopa smrtnosti što se dodatno povezuje i sa zagađenjem vazduha odnosno sa oštećenjem ozonskog omotača (Gorham i sar., 1989; Osborne i Hutchinson, 2002). Afro Amerikanke imaju lošiju prognozu karcinoma dojke u poređenju sa belkinjama Amerikankama, dok Hispano Amerikanke imaju manje agresivnu formu bolesti u odnosu na Afrikanke, ali agresivniju u poređenju sa belkinjama (Elledge i sar., 1994). U navedenoj studiji veličina tumora i smanjena učestalost limfnih metastaza je bila asocirana sa smanjenom pigmentacijom kože.

Pretraživanjem literature, može se naći veliki broj studija koje ukazuju na povezanost geografskih razlika koje koreliraju sa dostupnošću Sunčevog zračenja i incidence nastanka različitih tipova kancera. $\mathrm{Na}$ primer, $\mathrm{u}$ poređenju sa Afrikancima iz Nigerije, Afro Amerikanci imaju šest puta povećan rizik za razvoj kancera prostate (Osborne i Hutchinson, 2002). Latentne forme kancera prostate su jednako zastupljene kod afrikanske i kavkazijanske rase. Kod Azijata, rizik za nastanak kancera prostate je povećan među migrantima, što se povezuje sa ishranom koja je manje bogata ribljim uljem (Osborne i Hutchinson, 2002). 
Rizik od nastanka kancera kolona i mortaliteta raste sa porastom geografske širine i smanjenjem intenziteta Sunčevog zračenja i u urbanim regionima je dodatno asociran sa kiselom zagađenošću vazduha (Gorham i sar., 1989). Značajan izuzetak je Japan, koji ima relativno nisku incidencu kancera kolona (Osborne i Hutchinson, 2002).

Veći indeks sunčanja i izloženost UV zračenju je imao protektivni efekat za razvoj kancera prostate (John i sar., 2005). Najveći protektivni efekat je zabeležen u slučajevima regularnog sunčanja tokom detinjstva.

$\mathrm{Na}$ osnovu epidemioloških podataka, uočeno je da je promena količine vitamina D asocirana sa pojavom karcinoma dojke, prostate i kolona (Deeb i sar., 2007). Nekoliko studija je sugerisalo postojanje recipročne veze između slabog unosa vitamina D i pojave kolorektalnog karcinoma, što drugim studijama nije potvrđeno (Osborne i Hutchinson, 2002).

\subsection{Receptor za vitamin $D$}

Već tokom druge polovine XX veka, tačnije 1969. godine je potvrđeno

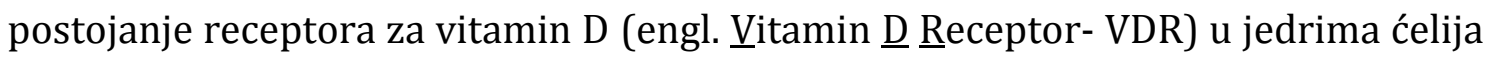
koje su inkubirane sa radioaktivno obeleženim $1 \alpha 25(\mathrm{OH})_{2} \mathrm{D}_{3}$ (Norman, 2006; Lin i White, 2003). Receptor je najpre identifikovan u jedrima ćelija intestinuma kokoške, a kasnije i u drugim ćelijama i tkivima (Osborne i Hutchinson, 2002). VDR je prisutan u preko 30 tkiva kod čoveka (Norman, 2006). Dokaz o prisustvu receptora za vitamin $\mathrm{D}$ u tkivima koja nemaju ulogu u homeostazi mineralnih jona kalcijuma i fosfata je ključno i ukazivalo je na otkriće drugih funkcija koje vitamin D ima.

Receptor za vitamin D pripada superfamiliji steroidnih hormonskih jedarnih receptora, konzervirane domenske strukture, koji predstavljaju ligande, aktivatore transkripcionih faktora. Da bi se izmenio nivo transkripcije ciljnih gena, VDR se vezuje za $1 \alpha 25(\mathrm{OH})_{2} \mathrm{D}_{3}$, čime postaje aktivisani transkripcioni faktor koji dalje interaguje sa koregulatorima i transkripcionim preinicijacionim kompleksom (Dusso i sar., 2005). U tom smislu, bitno je poznavanje građe receptora zahvaljujući 
kojoj je moguće obavljanje uloge aktivacije transkripcionih faktora. Receptor je izgrađen od 427 amino kiselina, težak $100 \mathrm{kDa}$ i veličine $10 \mathrm{~nm}$ (www2.cnrs.fr/en/1961.htm). Kristalna struktura VDR-a je prikazana na Slici 12.
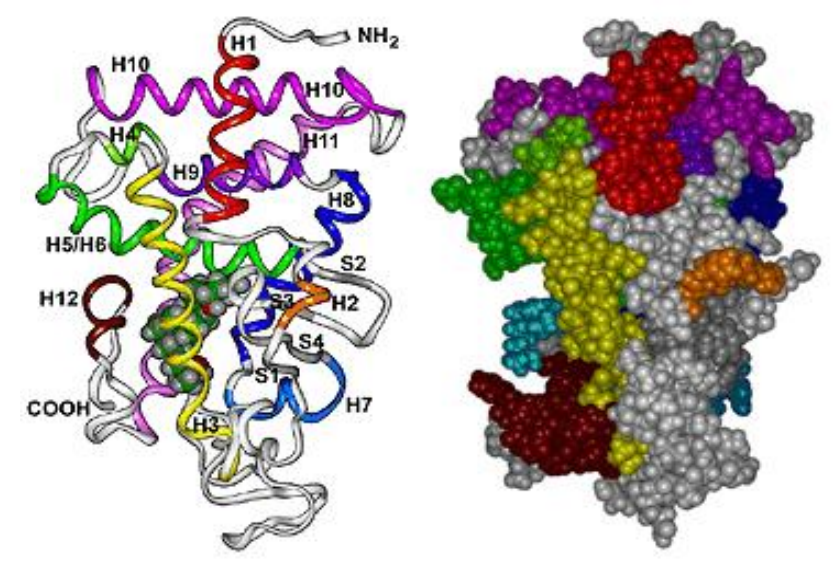

Slika 12. Kristalna struktura receptora za vitamin D (Preuzeto: www.drnickcampos.com/health-newsletter/VitD.html)

Humani VDR protein ima domensku strukturu, koja je, kao i kod drugih jedarnih receptora organizovana u pet regiona (A-E) (Slika 13.). Ligand vezujući domen (engl. Ligand Binding Domain-LBD) se nalazi na COOH-terminusu VDR molekula i odgovoran je za visoko afinitetno vezivanje kalcitriola, $1 \alpha 25(\mathrm{OH})_{2} \mathrm{D}_{3}$. Druge metaboličke forme kalcitriola: $25(\mathrm{OH}) \mathrm{D}_{3}$ i $24,25(\mathrm{OH})_{2} \mathrm{D}_{3}$ se vezuju sa 100 puta manjim aviditetom. Naime A prsten kalcitriola sadrži $1 \alpha$ hidroksilnu grupu zahvaljujući kojoj se vrši vezivanje za VDR. Afinitet za vezivanje liganda nije apsolutni pokazatelj transkripcione aktivnosti VDR-a aktiviranog ligandom. Intracelularni vezujući proteini koji posreduju u isporučivanju liganda ka i od VDR receptora mogu menjati stepen vezivanja odnosno asocijacije liganda i VDR-a. Na $\mathrm{COOH}$ kraju ligand vezujućeg domena se nalazi ligand zavisni aktivator funkcije 2 (AF2) (Slika 13.), koji ima glavnu ulogu u ostvarivanju konformacionih promena trodimenzionalne strukture VDR-a i koji je esencijalan za aktivaciju transkripcije (Lin i White, 2003; Dusso i sar., 2005). Ovaj aktivacioni korak je neophodan za 
pokretanje motornih proteina koji su odgovorni za brzo translociranje citoplazmatičnog VDR molekula do jedra pomoću mikrotubula (Dusso i sar., 2005).

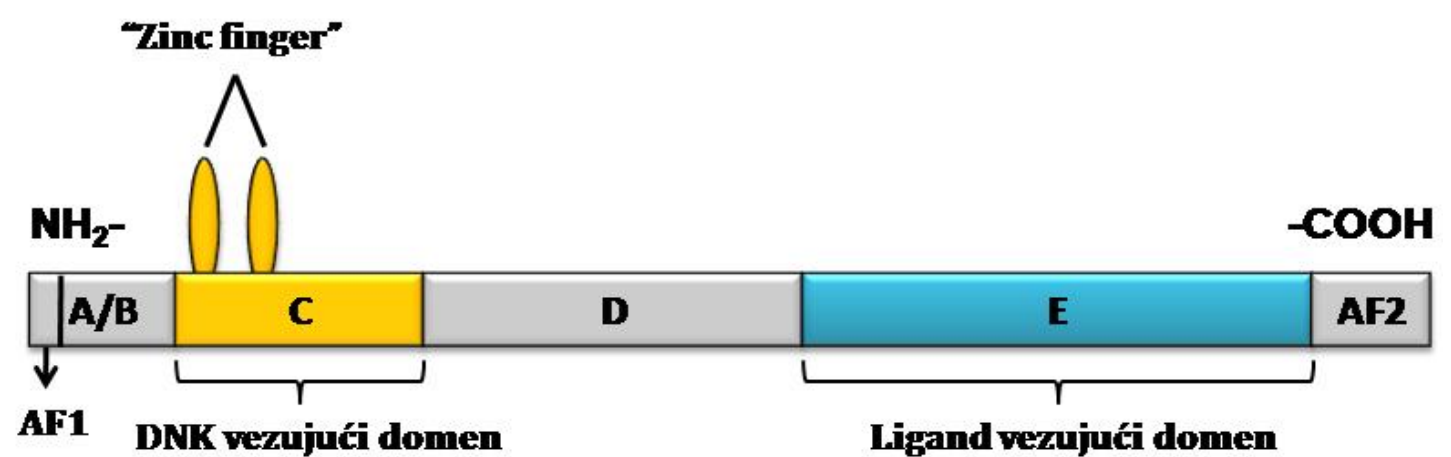

Slika 13. Šematski prikaz građe VDR receptora

DNK vezujući domen (engl. DNA Binding Domain-DBD) je visoko konzerviran među steroidnim jedarnim receptorima i nalazi se u C regionu VDR proteina (Slika 13.). DBD je organizovan u dva „Zn-zinc“ modula. „Zinc finger“ je DNK vezujući motiv koji je odgovoran za visoko afinitetnu interakciju sa specifičnim DNK sekvencama u promotorskom regionu ciljnih gena, nazvanih

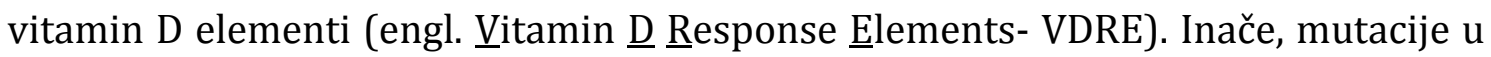
„zinc finger“ regionu humanog VDR-a rezultuju u defektnom vezivanju za DNK i posledično najtežim kliničkim fenotipovima rezistencije na vitamin D.

$\mathrm{Na} \mathrm{N}$ terminalnom kraju VDR proteina, u okviru A/B domena se nalazi ligand zavisni transaktivacioni domen AF1 (Slika 13.), koji ima bitnu ulogu u ostvarivanju tkivno specifične funkcije steroidnih receptora (Orlov i sar., 2012; Carlberg i Seuter, 2009). S obzirom da je A/B domen relativno kratak u VDR proteinu, funkcija AF1 može biti ograničena (Amano i sar., 2009).

VDR protein se može naći i u citoplazmi i jedru, ali se akumulira u jedru nakon vezivanja kalcitriola (Hansen i sar., 2001). Slično drugim jedarnim receptorima, VDR funkcioniše kao heterodimer sa članovima familije receptora: retinoid X receptorima (engl. Retinoid $\underline{X}$ Receptor-RXR) (Slika 14.). Asocijacija VDR-a sa RXR-om podrazumeva dimerizaciju površine u tri različita domena VDR molekula i indukuje VDR konformaciju koja je neophodna za transaktivirajuću funkciju VDR-a, kao i visokoafinitetno vezivanje za DNK (Dusso i sar., 2005; Lin i White, 2003). Vezivanje kompleksa kalcitriol-VDR-RXR za VDRE uzrokuje savijanje 
DNK za 55 stepeni iz horizontalnog položaja, ali veza između savijanja DNK u VDR posredovanoj transkripciji je još uvek nejasna. RXR se vezuje za 5' kraj, a VDR sa 3' kraj VDRE elemnata unutar promotora.

VDRE elementi se sastoje od dva heksanukleotidna ponovka koja su razdvojena varijabilnim brojem nukleotida (npr. GGTCCA-N-GGTCCA, gde je N broj nukleotida) (Orlov i sar., 2012; Amano i sar., 2009). Najčešći VDRE tip, DR3, sadrži dva ponovka konsenzus sekvence AGGTCA, međusobno odvojenu sa tri nukleotida (Slika 14.). Ova sekvenca usmerava VDR-RXR heterodimer do promotorskog regiona ciljnih gena kalcitriola.

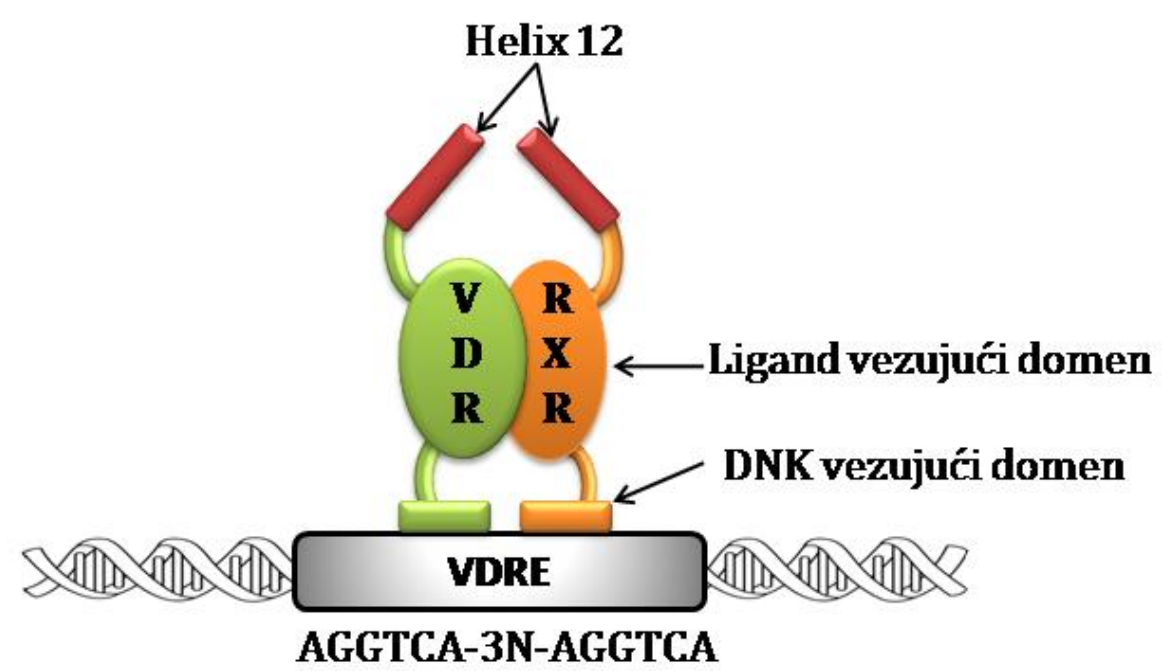

Slika 14. Šematski prikaz vezivanja VDR-RXR heterodimera za DR3 VDRE element promotora ciljnog gena

VDR vezujući element DR3 je identifikovan u velikom broju regulatornih regiona mnogih gena, između ostalog u CYP24A1 genu. Drugi tip VDRE, IP9 se sastoji od dve invertovane palindromske sekvence odvojene sa devet nukleotida. Interesantno je da su VDRE elementi gena čija je aktivnost suprimirana VDR-u sličnim DR3 sekvencama koje su detektovane u genima čija je transkripcija indukovana vitaminom D. Stoga se dugo postavljalo pitanje koji mehanizam zapravo određuje da li će genska transkripcija biti suprimirana ili indukovana kalcitriolom. Otkriće interakcije VDR-a sa jedarnim koregulatornim molekulima daje novi uvid u načine za pozitivnu i negativnu regulaciju transkripcije 
posredovane VDR-om. Dva domena VDR-a imaju ulogu adaptorne površine za jedarne proteine neophodne za interakciju VDR-a sa koregulatorima. Prvi je RXR heterodimerizujući domen, visoko konzerviran među jedarnim receptorima, koji formira deo vezujuće površine sa transkripcionim koaktivatorima. Drugi domen je prethodno opisani AF2, koji prolazi kroz veliku konformacionu promenu nakon vezivanja liganda, izlažući helix 12 (Slika 14.) što omogućava regrutovanje VDR interagujućih proteina, tačnije otpuštanje korepresora i vezivanje koaktivatora (Orlov i sar., 2012).

Koregulatori se mogu podeliti u tri funkcionalne grupe:

1) kompleks koregulatora koji reguliše transkripcionu aktivnost direktnom interakcijom sa transkripcionim faktorima i RNK polimerazom II

2) kompleks koji učestvuje u modifikaciji histonskih repova acetilacijom i deacetilacijom

3) kompleks uključen u ATP zavisno remodelovanje hromatina.

Čitav kompleksni put regulacije genske transkripcije posredovane VDR-om bi se mogao ukratko predstaviti na sledeći način (Slika 15.): $1 \alpha 25(\mathrm{OH})_{2} \mathrm{D}_{3}$ disocira sa vitamin D vezujućeg proteina u cirkulaciji, ulazi u ćeliju i vezuje se za receptor za vitamin D, koji se nalazi u citosolu i/ili jedru (Osborne i Hutchinson, 2002). Ovo ligandno vezivanje dovodi do konformacionih promena u samom receptoru, izlažući površinu za vezivanje koregulatornih faktora i dimerizaciju sa RXR-om, koji je podređen, ali obavezan član za potpunu transaktivaciju VDR-a. Heterodimerni kompleks kalcitriola i receptora za vitamin D, nakon vezivanja za retinoid $\mathrm{X}$ receptor interaguje sa regionima DNK, VDRE elementima preko promotora ciljnih gena, što za ishod ima aktivaciju ili represiju transkripcije. Kontrola transkripcije zahteva dodatno regrutovanje koregulatora (Bikle, 2009). 


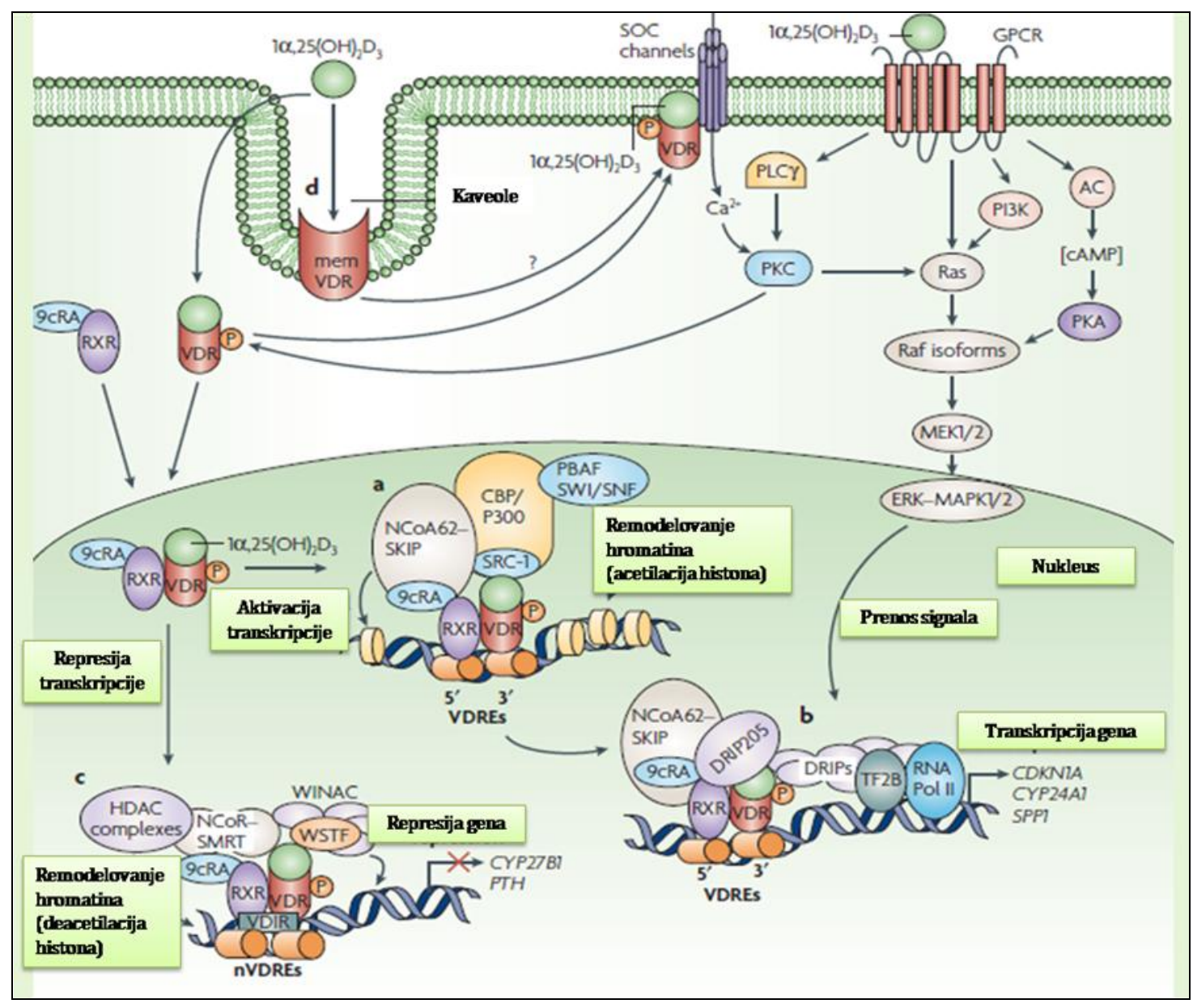

Slika 15. Regulacija genske ekspresije posredovane VDR-om (Preuzeto: Deeb i sar., 2007, modifikovano)

Put transkripcione aktivacije uključuje vezivanje koaktivatora SRC1 (ili SRC2, SRC3), NcoA62-SKIP i histonskih acetiltransferaza: CBP-p300 i PBAF-SWISNF, koji vrši acetilaciju histona u nukleozomu i oslobađa DNK za transkripciju. Kada se hromatin dekondenzuje, VDR-interagujući proteini (DRIP) formiraju kompleks koji se vezuje za AF2 domen VDR receptora. DRIP205 interaguje direktno sa VDR-om, tj. AF2 domenom. Ovaj DRIP kompleks, koji se sastoji od oko 15 proteina predstavlja most između VDR-a i transkripcione mašinerije, s obzirom da interaguje sa transkripcionim faktorima, uključujući transkripcioni faktor 2B (TF2B) i RNK polimerazu II, čime se inicira transkripcija (Slika 15.). Dakle, jedarni koaktivatori sinergistički deluju sa VDR-om i značajno amplifikuju gensku transkripciju (Dusso i sar., 2005). 
U slučaju transkripcione represije posredovane VDR-om (Slika 15.), vezivanje VDR-RXR kompleksa za VDRE elemente regrutuje korepresor VDIR, disocijaciju histonskih acetiltransferaznih koaktivatora i regrutovanje korepresora histonskih deacetilaza (HDAC, NcoR-SMRT), koji održavaju hromatin u transkripciono neaktivnom stanju. Ovi molekuli onemogućavaju oslobađanje hromatina i samim tim vezivanje proteina (TATA vezujućih proteina), koje je obavezno za inicijaciju transkripcije ciljnih gena pomoću RNK polimeraze II. Williams sindrom transkripcioni faktor (WSTF) pojačava represiju tako što interaguje sa multifunkcionalnim ATP-zavisnim hromatin remodelujućim kompleksom (WINAC). To vodi represiji gena, među kojima je i CYP27B1 gen. Jedan od komodulatora NcoA62/Skip ima bifunkcionalnu ulogu i može učestvovati u transkripcionoj inicijaciji ili supresiji, zavisno od tipa ćelije i ekspresije koregulatornih molekula.

Iako je VDR jedarni receptor, zabeleženo je njegovo prisustvo i u citoplazmi, tako da je pored genomskih signalnih puteva vitamina $D$, poznat i negenomski put aktivacije. Naime, kalcitriol se može vezati za citosolni i membranski VDR (koji je nađen u kalveolama), koji će se potom translocirati u jedro, čime se generiše niz signala koji vode transkripcionoj represiji ili aktivaciji. U kancer ćelijama kolona, citosolni pul VDR-a može brzo aktivirati intracelularne signalne kaskade (u odgovoru na tretman kalcitriolom), što na kraju pojačava transkripcionu regulaciju jedarnog VDR-a (Srinivasan i sar., 2011).

Sumirano, glavne faze VDR kontrole genske transkripcije podrazumevaju (Dusso i sar., 2005):

1. Vezivanje liganda $1 \alpha 25(\mathrm{OH})_{2} \mathrm{D}_{3}$

2. Heterodimerizacija sa RXR

3. Vezivanje heterodimera za VDRE elemente u promotoru gena koji reaguju na $1 \alpha 25(\mathrm{OH})_{2} \mathrm{D}_{3}$

4. Regrutovanje koregulatora u transkripciono preinicijacioni kompleks koji pojačava ili suprimira nivo genske transkripcije 
Iz svega do sada navedenog je jasno da je dinamična i koordinisana interakcija VDR-a i koregulatora (koaktivatora i korepresora) odgovorna za efikasnu regulaciju transkripcije (Dusso i sar., 2005; Amano i sar., 2009).

Početkom 2012 godine, tim stručnjaka sa Instituta za Genetiku, Univerziteta u Strazburu je predstavio po prvi put trodimenzionalnu strukturu ovog receptora $\mathrm{u}$ visokoj rezoluciji (Orlov i sar., 2012) (Slika 16.). Pre ovog prikaza istraživači su pretežno proučavali samo prethodno opisana dva dela receptora za vitamin $\mathrm{D}$ i to DNK interagujući region i vitamin D vezujući domen, čija je struktura proučavana primenom tehnika kristalografije. Ovi, prilično novi nalazi nam daju nove i preciznije informacije o funkcionisanju receptora. Otkrivaju nam da VDR i njegov „partner“ RXR formiraju otvorenu strukturu sa vitamin D vezujućim domenom skoro perpendikularnim sa DNK vezujućim domenom. Ovakva struktura ukazuje da postoji kooperacija između dva domena koji zajedno mogu, sa visokim nivoom preciznosti vršiti regulaciju ekspresije ciljnih gena.

\section{Ligand vezujući domen-LBD}

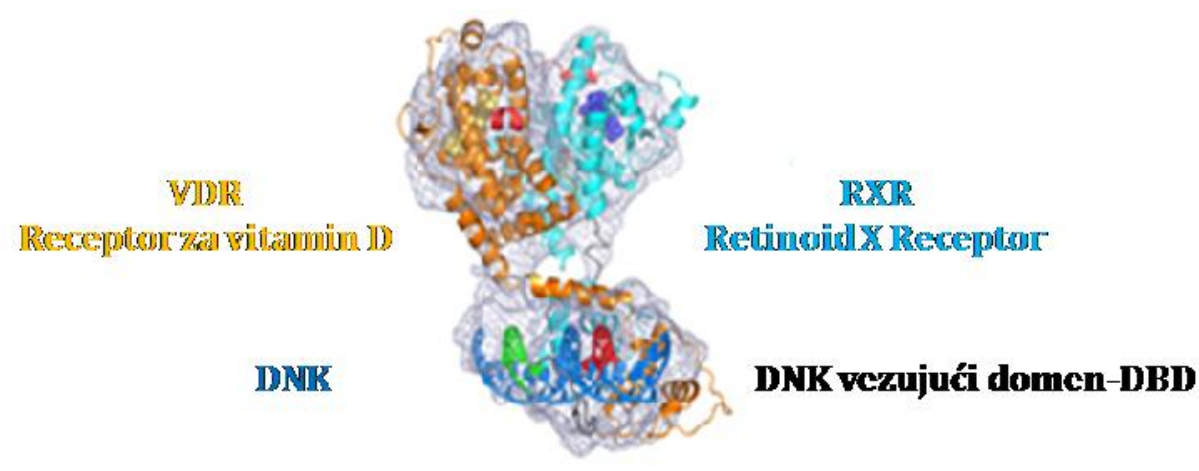

Slika 16. 3D struktura receptora za vitamin D i RXR receptora (preuzeto: Orlov i sar., 2012, modifikovano)

Prema literaturnim podacima, transkripcija preko 200 gena je regulisana kompleksom VDR-RXR (Field i Newton-Bishop, 2011). Iako veliki broj gena može biti regulisan vitaminom $D$, samo nekolicina njih sadrži VDRE elemente $u$ promotorskom regionu i može biti pod direktnom transkripcionom kontrolom vitamina D (Lamprecht i Lipkin, 2003). Međutim, noviji podaci govore da je 
identifikovano čak 2776 VDR vezujućih mesta u genomu nakon stimulacije kalcitriolom, primenom metode masivnog paralelnog sekvenciranja (Ramagopalan i sar., 2010). Povećano VDR vezivanje je identifikovano u intronskim regionima (36\%) i intergenskim regionima (28\%). Pored toga je zabeleženo 229 gena sa značajnim promenama nivoa ekspresije u odgovoru na vitamin D (Ramagopalan i sar., 2010). Identifikovana VDR vezujuća mesta su lokalizovana u blizini gena za koje je pokazano da su asocirani sa nastankom kancera i autoimunskih bolesti (Ramagopalan i sar., 2010). Broj malignih ćelija koje eksprimiraju VDR je, prema trenutnim podacima, veliki (Carlberg i Seuter, 2009). Vitaminom D posredovana represija ili aktivacija specifičnih protoonkogena ili tumor supresornih gena, koji su vezani za proliferaciju i diferencijaciju, je primećena u velikom broju zdravih i tumorskih tkiva. Vezivanje kalcitriola za VDR će stimulisati ekspresiju inhibitora ćelijskog ciklusa p21 i p27 i ekspresiju molekula ćelijske adhezije, E-cadherina (Palmer i sar., 2001) i inhibirati transkripcionu aktivnost $\beta$-katenina (Bikle, 2009). U keratinocitima, koji eksprimiraju VDR (Reichrath i sar., 1999), kalcitriol ima ulogu u reparaciji DNK oštećenja uzrokovanih UV zračenjem, redukuje apoptozu i povećava ekspresiju p53 gena (Bikle, 2009). $1 \alpha 25(\mathrm{OH})_{2} \mathrm{D}_{3}$ pospešuje diferencijaciju keratinocita i inhibira njihovu proliferaciju, što ukazuje na potencijalni značaj kalcitriola u tretmanu skvamocelularnih karcinoma glave i vrata uopšte, pa samim tim i oralnog karcinoma (Nagpal i sar., 2005). U epidermisu se proliferacija dešava u bazalnom sloju i diferencijacija započinje po izlasku keratinocita iz bazalnog sloja. Kalcitriol ograničava proliferaciju u bazalnom sloju i indukuje ekspresiju gena za produkciju permeabilnih barijera. Diferencijalna distribucija koaktivatora (DRIP i SRC3) unutar epidermisa omogućuje kalcitriolu da vrši prethodno navedene funkcije (Bikle, 2009). Svakako niz različitih bioloških uloga koje kalcitriol ostvaruje je moguć zahvaljujući postojanju VDR receptora, koji prenosi signale na prethodno opisan kompleksan način. 


\subsubsection{Gen za receptor za vitamin $D$}

Gen koji kodira receptor za vitamin D (VDR gen) je smešten na poziciji 12q12-14 (Slika 17.) i sastoji se od preko $100 \mathrm{~kb}$ (Denzer i sar., 2011; Rukin i Strange, 2007). VDR gen se sastoji od šest promotorskih regiona, alternativno splajsovanih netranslatiranih egzona $1 \mathrm{a}-1 \mathrm{f}$ i osam protein kodirajućih egzona 2-9 (Slika 18.) (Rukin i Strange, 2007; Deeb i sar., 2007). Region koji se nalazi uzvodno od egzona 1a, sadrži GC bogata ostrvca i ne sadrži TATA blok. DNK-vezujući domen VDR receptora, odgovoran za visoko afinitetnu interakciju sa VDRE elementima promotorskog regiona u ciljnim genima, je kodiran egzonima 2-4. Ligand vezujući domen VDR proteina je kodiran egzonima 6-9 i odgovoran je za visoko afinitetno vezivanje kalcitriola

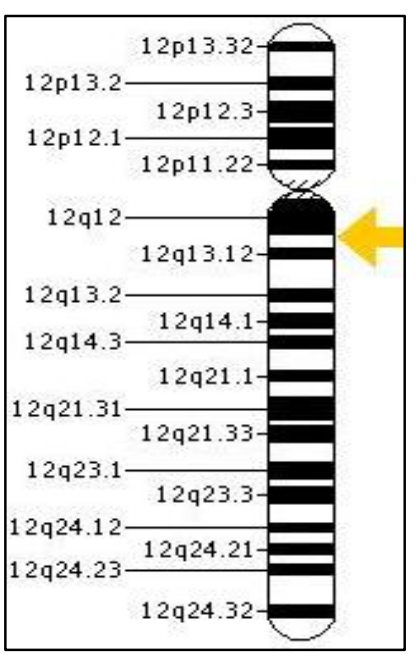
(Slika 18.) (Rukin i Strange, 2007)
Slika 17. Pozicija VDR gena

(preuzeto:www.ghr.nlm.nih.gov/gene/VDR)

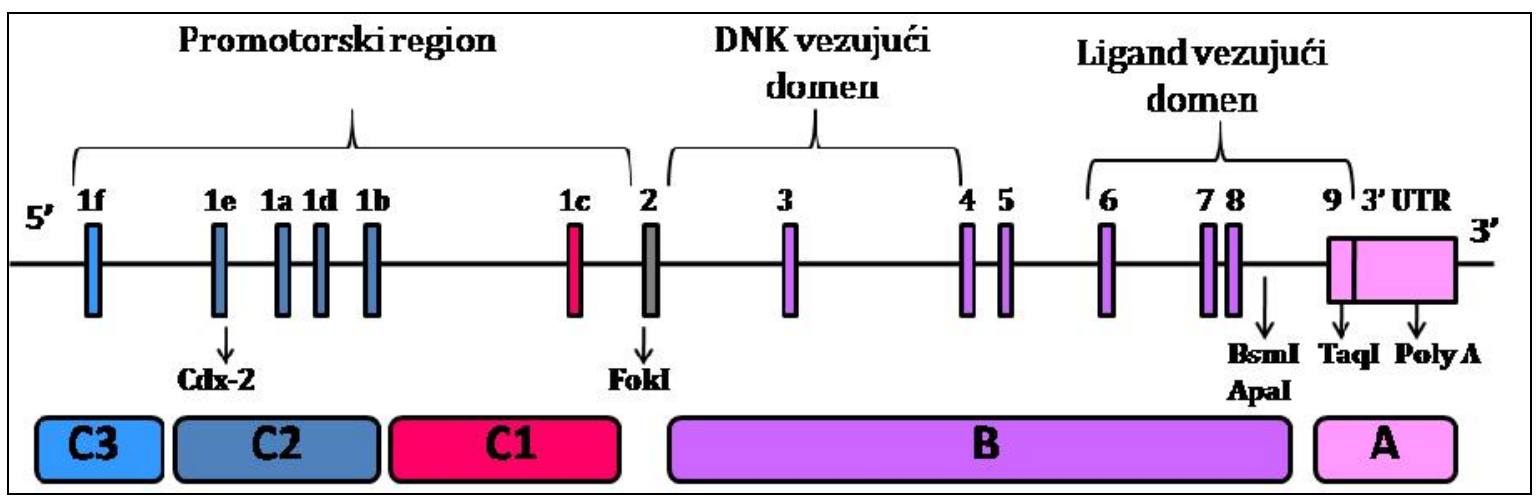

Slika 18. Šematski prikaz građe VDR gena sa LD blokovima i pozicijama najčešće proučavanih SNP-ova

Do sada je, prema nekim podacima, otkriveno preko 470 polimorfizama nukleotidne sekvence u humanom VDR genu (Davis i Milner, 2011; Rukin i Strange, 2007). Unutar različitih populacija postoje varijacije u učestalosti alela, ali većina SNP-ova ima nisku učestalost što ih čini nepraktičnim za proučavanje. 
Ispitivanje svih detektovanih SNP-ova bi zahtevalo dosta vremena, ali sa studijama neravnoteže vezanosti i identifikacijom LD blokova, proučavanje SNPova nekog gena se svodi na ispitivanje relativno malog broja polimorfizama od ukupno detektovanih. Unutar VDR gena su identifikovana tri odvojena LD bloka i imenovana kao A, B i C blok (Slika 18.). Blok A se nalazi na 3' kraju VDR gena egzona 9 i čini oko $10.5 \mathrm{~kb}$. Blok B sadrži egzone 3-9 i čini ga 40.8 kb i sastoji se od dva odvojena bloka B1 i B2. Blok B i C su odvojeni sa 1.3 kb što uključuje egzon 2. Blok C obuhvata nekodirajuće egzone (1a-1f) i sadrži 92.9 kb. Blok C je takođe podeljen u tri manja C1, C2 i C3 podbloka. Prema nekim istraživanjima ljudi u Severnoj Africi i Gambiji imaju različitu distribuciju LD regiona, posebno C1, C2 i C3 podbloka u poređenju sa Evropskom populacijom (Nejentsev i sar., 2004). Varijacije u distribuciji LD blokova, koje mogu biti prisutne između rasa, mogu pomoći u objašnjavanju različitih incidenci javljanja kancera među rasama, koji su u asocijaciji sa vitaminom D. Najviše proučavani SNP-ovi VDR gena se nalaze u B LD bloku (BsmI i ApaI). Dosta je proučavan FokI polimorfizam, detektovan u egzonu 2, između B i C LD bloka. Ovaj polimorfizam se ne nalazi u LD-u sa ostalim SNP-ovima u VDR genu.

S obzirom na postojanje alternativnog splajsovanja i/ili alternativnog korišćenja promotorskog regiona, nivo VDR transkripta je tkivno specifičan. Upravo se ovom pojavom može objasniti detekcija visokog nivoa ekspresije VDR-a u metaboličkim tkivima, kao što su bubrezi, intestinum, koža i tireoidna žlezda i umereni nivo ekspresije u ostalim tkivima. Ekspresija VDR gena se može regulisati velikim brojem stimulusa, uključujući estrogen, citokine, faktore rasta (npr. Sp1, WT1), peptidne hormone i vitamin D (Maruyama i sar., 2006). Faza ćelijskog ciklusa u kom se ćelija nalazi, kao i stadijum diferencijacije ćelije takođe utiču na nivo iRNK VDR gena (Osborne i Hutchinson, 2002). Rezultati jedne studije su pokazali da protein p53 direktno povećava ekspresiju humanog VDR gena (Maruyama i sar., 2006). Naime, pokazano je da promotorski i intronski regioni VDR gena sadrže nekoliko vezujućih mesta za p53. Stoga se smatra da VDR gen ima potencijalnu tumor supresorsku aktivnost. Činjenica da je VDR zapravo target gen p53, ukazuje da to može biti jedan od uzročnika disregulacije VDR-a u kanceru (Maruyama i sar., 2006). VDR putanje se mogu delimično preklapati sa p53 
putanjama, zato što je nekoliko nishodnih VDR gena istovremeno meta i p53 (Slika 19.).

\section{Apoptoza}

Diferencijacija

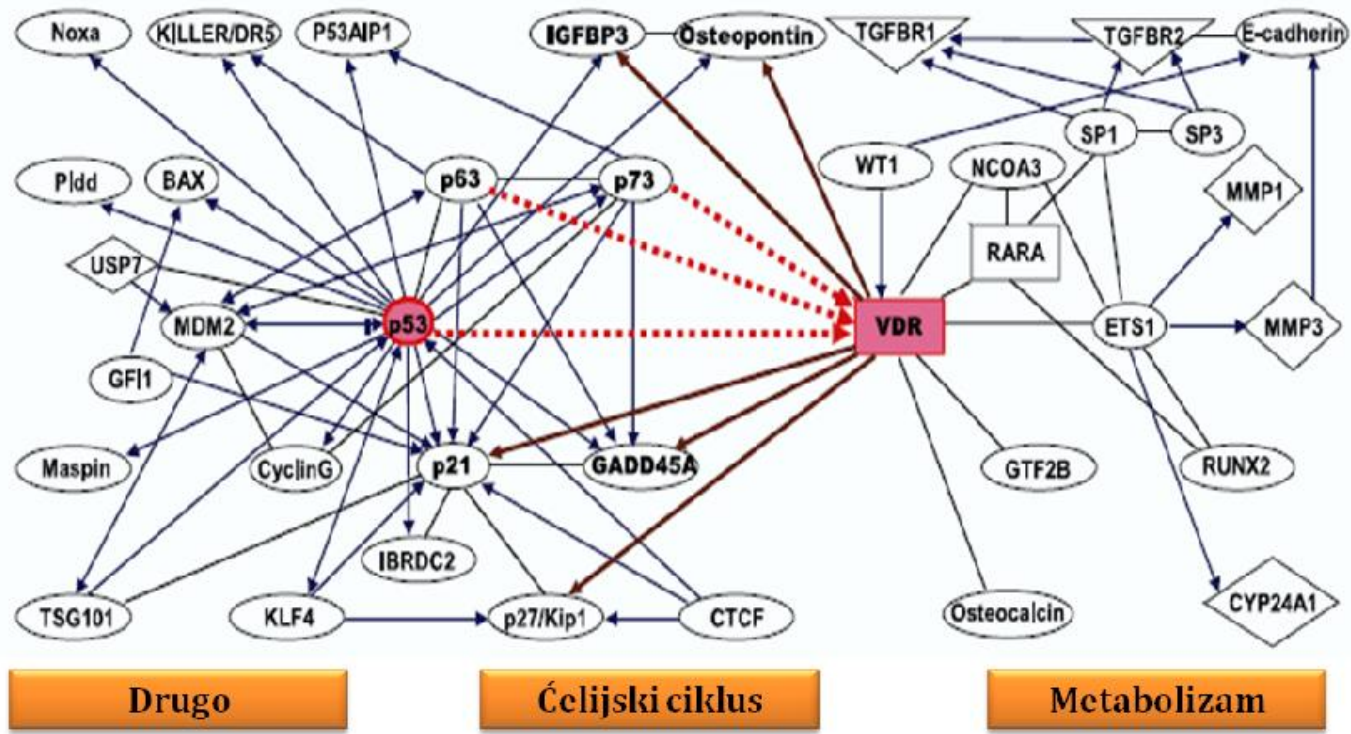

Slika 19. Dijagram zajedničkih ciljeva gena p53 i VDR gena (preuzeto: Maruyama i sar., 2006, modifikovano)

U prisustvu genotoksičnih agenasa VDR indukuje ekspresiju ciljnih gena asociranih sa regulacijom ćelijskog ciklusa i apoptozom. Razlika u VDR ciljnim genima pod normalnim i stresnim okolnostima može delimično biti objašnjena p53 zavisnom regulacijom VDR proteinske ekspresije idukovane genotoksičnim stresom. VDR ciljni geni mogu biti indukovani stimulacijom vitaminom D u prisustvu inaktivnog mutiranog p53 ili u ćelijama deficijentnim za p53 protein (Maruyama i sar., 2006). Pod normalnim fiziološkim uslovima VDR preferencijalno indukuje ciljne gene uključene u metabolizam kalcijuma i ćelijsku diferencijaciju (npr. CYP24A1). U prisustvu genotoksičnog stresa, VDR indukuje ciljne gene asocirane sa regulacijom ćelijskog ciklusa i apoptozom.

Jednom studijom je pokazano da je ekspresija VDR gena bila umereno smanjena u tumoru kolona, pluća i dojke, ali visoko povećana u tumoru ovarijuma (Maruyama i sar., 2006; Anderson i sar., 2006). Odsustvo ili nizak nivo VDR 
ekspresije je u vezi sa lošim preživljavanjem (Maruyama i sar., 2006). Poznato je da je tokom tumorske progresije ekspresija VDR gena snižena, iako regulatorni mehanizmi VDR ekspresije nisu u potpunosti poznati (Maruyama i sar., 2006).

Ekspresija VDR gena može biti snižena transkripcionim represorom SNAIL gena (Maruyama i sar., 2006). Visok nivo SNAIL ekspresije je asociran sa ćelijskom dediferencijacijom i niskim nivoom VDR proteina. SNAIL protein interaguje direktno sa VDR promotorom, suprimirajući mu aktivnost, pri čemu je onemogućena indukcija E-kadherina i drugih VDR target gena.

\subsubsection{Polimorfizmi u VDR genu}

Interesovanje za proučavanje polimorfizama u VDR genu se značajno povećalo nakon što je istraživanjima pokazano postojanje asocijacije između određenih VDR polimorfizama i mineralne gustine kostiju (Osborne i Hutchinson, 2002). Većina studija ima za cilj pronalaženje asocijacije između pojedinačnih polimorfizama ili grupe polimorfizama i fizioloških parametara od interesa, i daleko manji broj studija/analiza se bavi proučavanjem direktnog uticaja alelske varijante na ekspresiju ili aktivnost VDR proteina. Do sada najviše proučavani polimorfizmi se nalaze $u$ intronu 8 između egzona 8 i 9, i nose naziv prema restrikcionim enzimima: BsmI, ApaI, kao i TaqI koji se nalazi u egzonu 9. Prema dosadašnjim saznanjima polimorfizmi BsmI, ApaI i TaqI, pojedinačno proučavani, nemaju uticaja na nivo ekspresije niti aktivnost translatiranog VDR proteina. Upravo ovakvi rezultati ostavljaju mogućnost da su uočene asocijacije ovih SNP-ova sa bolestima rezultat vezanosti za susedno gensko mesto ili čak drugi gen. Iako je u VDR genu identifikovan veliki broj polimorfizama nukleotidne sekvence, samo mali broj njih ima funkcionalni efekat. S obzirom na kompleksnu organizaciju VDR gena, identifikacija funkcionalnih polimorfizama je poseban izazov. Funkcionalnost polimorfizama se može proučavati na više nivoa: iRNK, proteinskom, ćelijskom nivou...Poznavanje molekularnih i funkcionalnih posledica VDR polimorfizama je krucijalno za potpuno razumevanje njihovog značaja, kao i potencijalnih asocijacija sa bolestima. Sistematičnije proučavanje VDR SNP-ova unutar populacija bi trebalo da posluži za traženje kliničke aplikacije u prevenciji 
ili tretmanu bolesti, kao i predikciji odgovora na terapiju vitaminom D ili njegovim sintetičkim analozima. Aplikativni značaj proučavanja VDR polimorfizama je potvrđen i primerom da izvesni VDR polimorfizmi utiču na tumorsku progresiju i tretman tamoksifenom u ranom stadijumu karcinoma dojke (Ylikomi i sar., 2002).

Generalno govoreći, proučavanje funkcionalnih efekata polimorfizama može biti problematično ekstrapolirati na in vivo sistem, s obzirom da se in vitro studije sprovode u strogo kontrolisanim uslovima, što nije slučaj $\mathrm{u}$ in vivo uslovima. Genetičke epidemiološke studije omogućavaju proučavanje funkcionalnosti SNP-ova na populacionom nivou. Zapravo, genetičke epidemiološke studije imaju za cilj proučavanje uloge VDR polimorfizama u relaciji sa podložnošću različitim bolestima, što može značajno pomoći u otkrivanju funkcionalnih efekata polimorfizama.

U predstojećem tekstu je dat pregled najproučavanijih polimorfizama $u$ VDR genu, od kojih su neki obuhvaćeni ovom doktorskom disertacijom.

\subsection{FokI (rs2228570)}

VDR FokI (rs2228570) polimorfizam predstavlja supstituciju timina citozinom $(\mathrm{T} / \mathrm{C})$ u startnom kodonu egzona 2 na poziciji +27823 , ili prema nekim podacima +30875 . Dobio je naziv po restrikcionoj endonukleazi FokI, koja se može koristiti za genotipizaciju. FokI endonukleaza prepoznaje specifičnu sekvencu nukleotida i vrši isecanje na mestu timina. Prisustvo FokI restrikcionog mesta (f) rezultira nastajanjem VDR proteina izgrađenog od 427 amino kiseline (divlji tip, engl. Wild Type (wt) ili M1 forma receptora), dok odsustvo restrikcionog mesta (F) rezultira sintezom kraćeg proteina koji se sastoji od 424 amino kiseline (M4 forma receptora) (Uitterlinden, 2004). Ove izoforme se ne razlikuju prema vezivanju za DNK, afinitetu za ligand, kao ni heterodimerizaciji sa RXR-om. Međutim, utvrđeno je da se ove dve varijante međusobno razlikuju prema funkcionalnosti za 1.7 puta u korist više aktivnosti FF varijante (Uitterlinden i sar., 2004; Denzer i sar., 2011). Naime, prisustvo mutiranog F alela ima umereno višu transkripcionu aktivnost, kao i veću interakciju sa in vitro transkripcionim faktorom 2B (TF2B) (Rukin i Strange, 2007) u poređenju sa divljim tipom, f alelom (Slika 20.) 


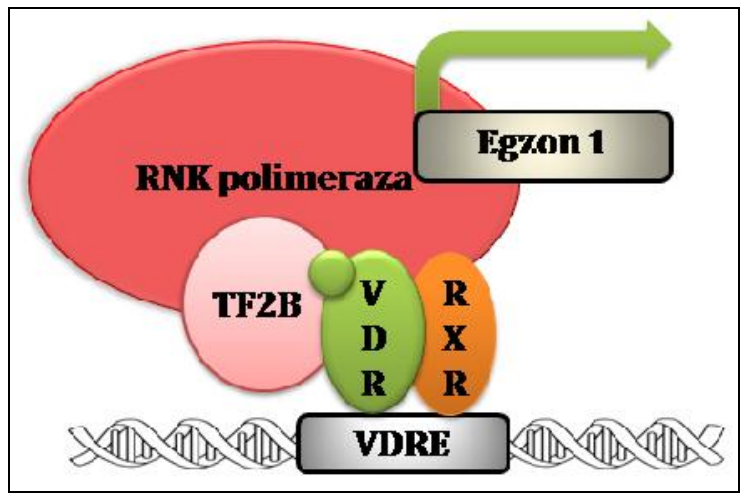

a)

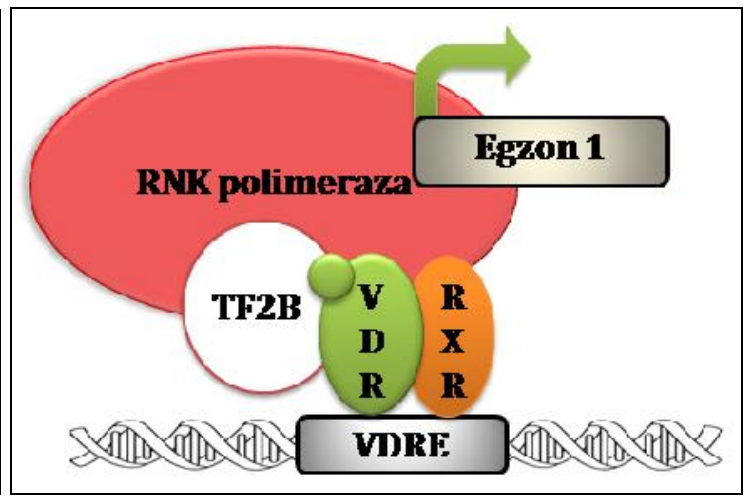

b)

Slika 20. Transkripciona aktivnost različitih alelskih varijanti FokI polimorfizma VDR gena a) mutirani F alel b) divlji f alel

S obzirom da se nalazi u egzonu 2, između B i C LD bloka, FokI polimorfizam se može smatrati nezavisnim markerom VDR gena, s obzirom da nije u neravnoteži vezanosti sa do sada poznatim i proučavanim polimorfizmima i da je LD oblast koja okružuje ovaj polimorfizam relativno mala (Uitterlinden i sar., 2004).

FokI polimorfizam, bilo samostalno ili u kombinaciji sa drugim VDR polimorfizmima je dosta proučavan u studijama rizika za nastanak različitih tipova kancera, a posebno kancera dojke. Prema nekim istraživanjima, FokI FF genotip je, zajedno sa ostalim VDR polimorfizmima povećavao rizik za kancer dojke u Kavkazoidnoj populaciji u Velikoj Britaniji. Sa druge strane, dve druge studije su pokazale da je kod žena sa ff genotipom postojala veća podložnost za kancer dojke u poređenju sa FF genotipom. Kod Afro Amerikanki FF genotip je bio asociran sa $50 \%$ smanjenim rizikom za kancer dojke (Osborne i Hutchinson, 2002) dok druga istraživanja nisu pronašla asocijaciju između FokI polimorfizma i povećanog rizika za kancer dojke među ženama u postmenopauzi. Ovakvi, međusobno konfliktni rezultati se mogu pripisati maloj veličini uzorka i odabira uzorka pacijenata iz populacije za svaku studiju (Alimirah i sar., 2011). 


\subsection{Poly A (rs2544038)}

$\mathrm{Na}$ 3'-netranslatirajućem regionu (UTR) VDR gena je identifikovan polimorfizam dužine poliadenilatnog repa (poly A), koji se smatra važnim u posttranskripcionoj kontroli genske ekspresije (Holt i sar., 2010). Varijante polyA su klasifikovane prema broju A nukleotida. Ukoliko je broj A nukleotida $\geq 17$, poly A varijanta se obeležava kao L (engl. Long) alel, dok u slučaju broja A nukleotida $\leq 15$ kao S (engl. Short) alel. S obzirom da se nalazi na 3'-UTR regionu VDR gena, ne utiče na strukturu VDR-a, iako je prema podacima nekih istraživačkih grupa L alel povezan sa produkcijom iRNK koja je stabilnija i/ili je efikasnije translatirana $u$ VDR protein nego u slučaju postojanja S alela (Whitfield i sar., 2001). Poly A rep se nalazi u neravnoteži vezanosti sa BsmI-ApaI-TaqI blokom i smatra se da na taj način može uticati na stabilnost iRNK (Dusso i sar., 2005).

Kada je reč o studijama asocijacije, Poly A polimorfizam je značajno asociran sa izmenjenim rizikom za nastanak kancera dojke i prostate (Osborne i Hutchinson, 2002). U slučaju kancera dojke, prisustvo L alela je bilo povezano sa $50 \%$ smanjenim rizikom (Osborne i Hutchinson, 2002). Za razliku od kancera dojke, prisusto L alela je bilo asocirano sa 3-5 puta povećanim rizikom za nastanak kancera prostate (Ingles, 1997; Taylor i sar., 1996).

\subsection{Cdx-2 (rs11568820)}

Cdx2 polimorfizam je otkriven najpre u populaciji Japanaca (Uitterlinden i sar., 2004) i predstavlja supstituciju adenina guaninom (A/G) u egzonu 1e promotorskog regiona na poziciji +1229 . Pokazano je da polimorfizam Cdx2 ima funkcionalni efekat i izvesni uticaj na ekspresiju VDR gena. Naime, prisustvo mutiranog alela rezultira nastankom VDR molekula sa defektnim vezujućim mestom za intestin specifični transkripcioni faktor Cdx2. Prisustvo A alela je povezano sa većom aktivnošću u poređenju sa $\mathrm{G}$ alelom, u smislu jačeg vezivanja Cdx2 transkripcionog faktora i više transkripcione aktivnosti (Uitterlinden i sar., 2004). Smatra se da A alel rezultuje višom transkripcionom aktivnošću i povećanjem ekspresije VDR-a, posebno u intestinumu, koji predstavlja glavno 
mesto resorpcije calcijuma (Heist i sar., 2008; Rukin i Strange, 2007). Takođe, A alel je povezan sa povećanom transkripcionom aktivnošću VDR-a u Caco-2 ćelijskim linijama kancera kolona (Rukin i Strange, 2007). Cdx-2 polimorfizam nije bio povezan sa preživljavanjem pacijenata sa ne-sitnoćelijskim karcinomom pluća (Heist i sar., 2008).

\subsection{BsmI (rs1544410)-ApaI (rs7975232)-TaqI (rs731236)}

S obzirom da je HapMap projektom utvrđeno da se navedena tri polimorfizma, locirana na 3' kraju VDR gena nalaze u jakoj neravnoteži vezanosti jedan sa drugim, najčešće su i proučavani zajedno. BsmI (rs1544410) predstavlja zamenu guanina adeninom (G/A) na poziciji +60890 i nalazi se u intronu 8 između egzona 8 i 9, gde je smešten i polimorfizam Apal (rs7975232), koji predstavlja supstituciju citozina adeninom (C/A) na poziciji +61888. U egzonu 9 je detektovan TaqI (rs731236), zamena timina citozinom (T/C) na poziciji +61938 . Funkcionalnim studijama ovih polimorfizama se nastoji utvrđivanje njihovog uticaja na regulaciju transkripcije, translacije ili RNK procesovanja, ali nisu dobijeni konzistentni rezultati između različitih studija (Barroso i sar., 2008).

S obzirom da su BsmI-ApaI-TaqI u jakom LD-u, smatra se da ovaj haplotipski blok ima uticaja na stabilnost iRNK. Dok se BsmI nalazi u slabijoj neravnoteži vezanosti sa preostala dva polimorfizma, ApaI i TaqI se međusobno nalaze u jakoj vezi. Još uvek je nerazjašnjeno kako BsmI i ApaI polimorfizam, koji se nalaze u nekodirajućem regionu VDR gena mogu uticati na funkcionalnost i biti asocirani sa izvesnim bolestima, ali se pretpostavlja da su navedeni polimorfizmi $u$ LD-u sa još uvek neidentifikovanim funkcionalno važnim alelskim mestima unutar VDR gena ili nekog od susednih gena na istom hromozomu, koji mogu imati ulogu $\mathrm{u}$ ispoljavanju fenotipskih osobina ili bolesti i stoga se mogu koristiti kao markeri.

Smatra se da je BAt haplotip povezan sa višim nivoom ekspresije iRNK nego baT haplotip, ali ovi rezultati nisu konzistentni među studijama (Uitterlinden i sar., 2004). BsmI ne menja strukturu i funkciju produkovnog VDR proteina te se može reći da nema funkcionalni efekat (Raimondi i sar., 2009). Međutim, ustanovljeno je da je BsmI polimorfizam u neravnoteži vezanosti sa poly A mikrosatelitom, pa se 
smatra da može uticati na stabilnost VDR iRNK (Liu i sar., 2011; Raimondi i sar., 2009; Uitterlinden i sar., 2004). Analize pojedinačnih polimorfizama pokazuju da je B alel BsmI polimorfizma asociran sa povišenom ekspresijom VDR gena i povišenim nivoom kalcitriola u serumu (Heist i sar., 2008). Sa druge strane, pokazano je da je smanjenje nivoa ekspresije VDR gena u slučaju kolorektalnog karcinoma nezavisno od genotipa BsmI polimorfizma (Parisi i sar., 2008). Skorašnja meta analiza je otkrila da je BsmI polimorfizam asociran sa rizikom razvijanja kolorektalnog karcinoma (Bai i sar., 2012).

Takođe, TaqI rezultuje supstitucijom amino kiseline izoleucina metioninom, za koju se smatra da dovodi do promene VDR funkcije, što bi moglo biti povezano sa razvojem i prognozom kancera (Liu i sar., 2011).

\subsection{EcoRV (rs4516035)}

Reč je o polimorfizmu koji je relativno retko proučavan u odnosu na ostale polimorfizme VDR gena. Smešten u egzonu 1a promotorskog regiona, rezultuje izmenom citozina u timin (C/T) na poziciji -1012. Nije poznato da ima funkcionalni efekat. Studije asocijacije su uglavnom rađene u odnosu na karcinome kože i to pretežno melanome. Jednom studijom je potvrđeno postojanje asocijacije između mutirane varijante EcoRV polimorfizma i rizika od nastanka kutanog melanoma (Povey i sar., 2007).

\subsubsection{6. rs11574085}

Polimorfizam u VDR genu, koji, prema našim saznanjima, do sada nikada nije proučavan u asocijaciji sa karcinomima, pa samim tim ni sa oralnim karcinomom. Nije poznato da ima funkcionalni efekat. $U$ vezi sa ovim polimorfizmom je dostupno veoma malo literaturnih podataka. 


\subsubsection{Učestalost SNP-ova i haplotipova VDR gena u različitim populacijama}

Nekoliko velikih studija je utvrdilo postojanje etničke varijabilnosti po pitanju zastupljenosti VDR polimorfizama. Na primer, divlji alel f FokI SNP-a se javlja kod Afrikanaca u manjoj zastupljenosti u poređenju sa Kavkazijancima i Azijatima, dok je učestalost B alela BsmI SNP-a mnogo niža kod Azijata u poređenju sa drugim populacijama (Tabela 2.) (Kostner i sar., 2009). Bitno je naglasiti da pored ovih razlika u učestalosti SNP-ova, funkcionalni efekti polimorfizama se ne razlikuju između etničkih grupa, prvenstveno zato što je fiziološka uloga vitamina D ista kod ljudi (Kostner i sar., 2009). Samo 7\% Azijata ima SNP na BsmI restrikcionom mestu, dok 74\% Azijata ima polimorfizam unutar ApaI restrikcionog mesta. Generalno govoreći, polimorfizmi nastaju kao slučajne mutacije, čija se učestalost može povećavati unutar etničke grupe do te mere, da bi bila proglašena polimorfizmom. Ovim evolucionim procesom se može objasniti postojanje razlika u učestalosti alela između različitih etničkih grupa (Uitterlinden i sar., 2004).

Tabela 2. Procentualne zastupljenosti minor alela VDR SNP-ova u različitim etničkim grupama

\begin{tabular}{|l|cccc|}
\hline \multirow{2}{*}{ VDR SNP } & \multirow{2}{*}{ Minor alel } & \multicolumn{3}{|c|}{ Etnička grupa (\%) } \\
\cline { 3 - 5 } & & Kavkazijanci & Azijati & Afrikanci \\
\hline \hline FokI & $\mathrm{f}$ & 34 & 51 & 24 \\
BsmI & $\mathrm{B}$ & 42 & 7 & 36 \\
ApaI & $\mathrm{A}$ & 44 & 74 & 31 \\
TaqI & $\mathrm{T}$ & 43 & 8 & 31 \\
Cdx2 & $\mathrm{A}$ & 19 & 43 & 74 \\
\hline \hline
\end{tabular}

Takođe, poznato je da postoje razlike u tipovima kao i učestalosti javljanja VDR haplotipova između različitih etničkih grupa (Tabela 3.). Upravo se 
postojanjem ovih razlika mogu objasniti varijacije u podložnosti bolestima koje su primećene među grupama. U tabeli 3. su prikazane učestalosti javljanja BsmI-ApaITaqI VDR haplotipova unutar različitih etničkih grupa.

Tabela 3. Zastupljenost haplotipova u različitim etničkim grupama

\begin{tabular}{|ccccc|}
\hline \hline \multirow{2}{*}{ VDR Haplotip } & Haplotip & \multicolumn{3}{c|}{ Etnička grupa (\%) } \\
\cline { 4 - 5 } & Kavkazijanci & Azijati & Afrikanci \\
\hline \hline \multirow{3}{*}{ BsmI-ApaI-TaqI } & baT & 43 & 75 & 26 \\
& BAt & 39 & 7 & 16 \\
& bAT & 11 & 17 & 59 \\
\hline \hline
\end{tabular}

Najviša učestalost baT haplotipa je zabeležena kod Azijata (75\%), za kojima slede Kavkazijanci (43\%) i Afrikanci (26\%) (Tabela 3.). Najčešći haplotip među Afrikancima, bAT, za učestalošću od $59 \%$ se relativno ređe sreće kod Azijata i Kavkazijanaca. Jasno je da haplotipske učestalosti između etničkih grupa pokazuju kompleksan obrazac koji se ne može izvesti na osnovu poznavanja učestalosti pojedinačnih polimorfizama koji ulaze u sastav haplotipskog seta. Naime, haplotipski set odslikava teoriju "Out of Africa" kojim se opisuje poreklo humanih populacija širom sveta, koje je istovremeno rezultat i interakcije gena i spoljašnje sredine, u kojima neke određene varijante mogu imati prednost za preživljavanje i reprodukciju (Uitterlinden, 2004). Pored toga, pretpostavlja se da zastupljenost relativno starih polimorfizama manje varira između različitih etničkih grupa, dok relativno noviji polimorfizmi mogu pokazivati jako velike razlike (Uitterlinden i sar., 2004). Na osnovu toga, na primer, $\mathrm{Cdx}-2$ polimorfizam bi se smatrao relativno novim, a FokI starim polimorfizmom (Uitterlinden i sar., 2004).

U cilju interpretacije studija asocijacije, može se pretpostaviti da individualni funkcionalni polimorfizmi mogu imati isti efekat u različitim etničkim grupama, jer fiziološka uloga endokrinog sistema vitamina D nije promenjena između različitih etničkih grupa. To takođe predstavlja osnovu za interpretaciju 
ekoloških studija, gde su alelske učestalosti između etničkih grupa u asocijaciji sa različitom incidencom bolesti/fenotipova između tih grupa (Uitterlinden i sar., 2004). Za nefunkcionalne ili polimorfizme nepoznate funkcionalnosti, situacija je različita zato što se u tom slučaju možemo osloniti na LD u kojima se nalaze proučavani polimorfizmi da bismo objasnili asocijacije sa bolestima. Na primer, ako je haplotip 1 asociran sa nekom bolešću u populaciji Kavkazijanaca i Afrikanaca, to može biti rezultat vezanosti sa potpuno različitim funkcionalnim alelima. Sa druge strane, ako je asocijacija takvog marker-haplotipa primećena kod Kavkazijanaca, a ne kod Azijata, može se pretpostaviti da je LD između markera i funkcionalnog alela različit među različitim populacijama. Teško je razumeti posledice etničkih varijacija alela, posebno zbog postojanja različitih sredinskih faktora između grupa, među kojima su ishrana, životne navike i drugo. Dodatno, postoje različite genetičke osnove između etničkih grupa u kojima VDR polimorfizmi interaguju jedan sa drugim ili sa drugim genetičkim varijantama drugih gena. U tom smislu je jasan izuzetan značaj i potreba definisanja haplotipskih struktura VDR polimorfizama različitih etničkih grupa. Na taj način i sa raspoloživim informacijama o sredinskim faktorima u različitim etničkim grupama, možemo u potpunosti razumeti interakcije između gena i spoljašnje sredine (Uitterlinden i sar., 2004).

\subsection{Enzim 1 $\alpha$-hidroksilaza i CYP27B1 gen}

Identifikacijom hidroksilnih metabolita vitamina D, uključujući glavnu cirkulišuću formu $25(\mathrm{OH}) \mathrm{D}_{3}$ i metabolički aktivnu formu $1 \alpha 25(\mathrm{OH})_{2} \mathrm{D}_{3}$, započinje istorija proučavanja enzima hidroksilaza vitamina D. Ulogu u anabolizmu odnosno katabolizmu vitamina D imaju enzimi iz velike familije enzima citohroma P450. Anabolizam je katalizovan enzimom $1 \alpha$ hidroksilazom $(1 \alpha(\mathrm{OH})$-aza), koji se sastoji od 508 amino kiselina (www.ncbi.nlm.nih.gov/protein/NP 000776.1). $1 \alpha$ hidroksilaza se nalazi na unutrašnjoj strani membrane mitohondrija proksimalnih tubula bubrega, gde vrši hidroksilaciju kalcidiola $25(\mathrm{OH}) \mathrm{D}_{3}$ na poziciji $1 \alpha$, čime nastaje biološki aktivna forma vitamina $D$, kalcitriol. Dakle, reč je 
o enzimu koji reguliše nivo biološki aktivne forme vitamina D. Na slici je predstavljena kristalna struktura enzima CYP27B1 (Slika 21.).

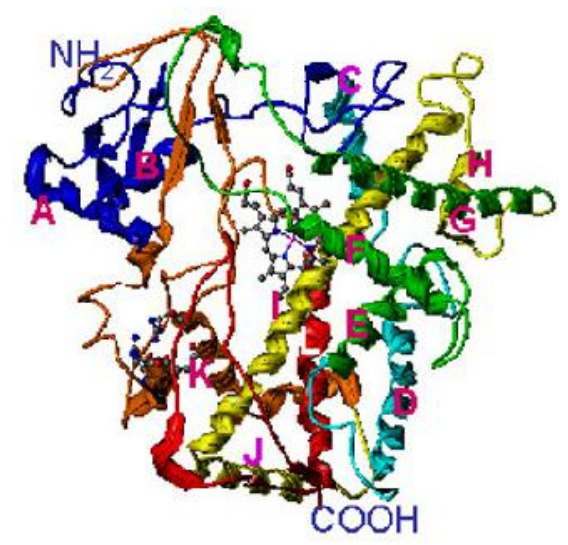

Slika 21. Kristalna struktura enzima $1 \alpha$-hidroksilaze (Preuzeto:www.bioscience.org/2005/v10/af/1514/ fulltext.asp?bframe=figures.htm\&doi=ye)

$1 \alpha$ hidroksilaza je kodirana CYP27B1 genom koji se nalazi na dugom kraku hromozoma 12 i poziciji 13.1-13.3 (12q13.1-13.3) prema Entrez Gene bazi (Slika 21.), dok prema Ensembl bazi zauzima 14.1 poziciju dugog kraka hromozoma 12. CYP27B1 gen se pored renalnih eksprimira u različitim ekstrarenalnim tkivima $\mathrm{u}$ telu (Turunen i sar., 2007), uključujući keratinocite, pluća, kolon, makrofage (Prosser i Jones, 2004), prostatu (Holick i sar., 2007) i druga tkiva i organe.

Ekspresija CYP27B1 gena je negativno regulisana kalcitriolom (Turunen i sar., 2007).

Slika 22. Pozicija CYP27B1 gena na dugom kraku hromozoma 20

(Preuzeto: www.ghr.nlm.nih.gov/gene/CYP27B1)

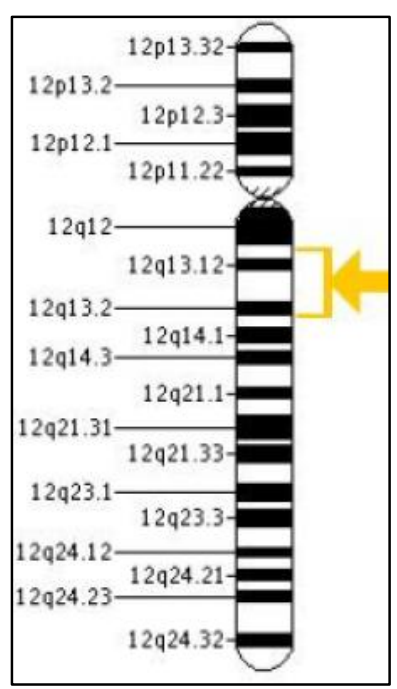

Uočeno je da je u ćelijama kancera prostate aktivnost $1 \alpha$-hidroksilaze snižena, što ukazuje na prisustvo nižih koncentracija kalcitriola u malignim ćelijama (Whitlatch i sar., 2002). Interesantno je zapažanje da su za sniženu ekspresiju CYP27B1 gena u ranim fazama neoplastične transformacije ćelija 
kancera prostate odgovorni mehanizmi epigenetičke regulacije. Stoga se može pretpostaviti da genetičke varijacije koje imaju uticaja na gensku ekspresiju ili funcionisanje proteina nemaju tako veliki efekat na maligne ćelije (Holt i sar., 2010; Hsu i sar., 2001).

\subsubsection{Polimorfizmi u CYP27B1 genu}

Postoji mali broj dokaza o identifikovanim funkcionalnim polimorfizmima $\mathrm{u}$ CYP27B1 genu (Holt i sar., 2010). Za razliku od polimorfizama u VDR genu koji su dosta proučavani, identifikovani SNP-ovi CYP27B1 gena su daleko manje zastupljeni u literaturi kada je reč o studijama asocijacije. Nedavno je identifikovano četiri nesinonimna SNP-a, ali su svi relativno retki (McCullough i sar., 2009) i za sada ne postoje dokazi da SNP-ovi menjaju gensku funkciju ili rizik za razvoj bolesti (Davis i Milner, 2011).

Relativno često proučavan polimorfizam, rs4646537, nije bio u vezi sa rizikom za nastanak kancera prostate kod Afro Amerikanaca (Bonilla i sar., 2011). Sa druge strane, potvrđena je asocijacija između genotipova CYP27B1 gena i rizika za nastanak kancera prostate, ali ne i sa agresivnošću bolesti (Holt i sar., 2010).

U ovoj doktorskoj disertaciji je analiziran polimorfizam rs4646536.

\subsubsection{1. rs4646536}

Reč je o polimorfizmu identifikovanom u intronu CYP27B1 gena, smeštenom na poziciji +2838, koji predstavlja izmenu timina citozinom (+2838 T/C). Prethodne studije su pokazale da je navedeni polimorfizam asociran sa nastankom dijabetesa tipa I (Bailey i sar., 2007). Naime, prisustvo divljeg tipa T alela je povezano sa smanjenim rizikom za razvoj dijabetesa tipa I u poređenju sa mutiranom formom. Pretpostavljeno je da SNP $+2838 \mathrm{~T} / \mathrm{C}$ u intronu snižava nivo aktivne $1 \alpha$ hidroksilaze i konverzije $25(\mathrm{OH}) \mathrm{D}_{3}$ do kalcitriola, što može voditi nastanku različitih bolesti (Bailey i sar., 2007). Upravo je to bio osnov za uključivanje datog polimorfizma u analizu naše studije. 


\subsection{Enzim 24-hidroksilaza i CYP24A1 gen}

Ulogu u katabolizmu, odnosno degradaciji fiziološki aktivne forme vitamina D hidroksilacijom bočnih lanaca, ima član familije enzima P450: 24-hidroksilaza (24(OH)-aza). Enzim je kodiran genom CYP24A1, koji se nalazi na dugom kraku hromozoma 20q13.2-13.3 (Slika 23.). Različite enzimske izoforme nastaju kao rezultat alternativnog splajsovanja transkripcionih varijanti.

Slika 23. Pozicija CYP24A1 gena na dugom kraku hromozoma 20

(Preuzeto: www.ghr.nlm.nih.gov/gene/CYP24A1)

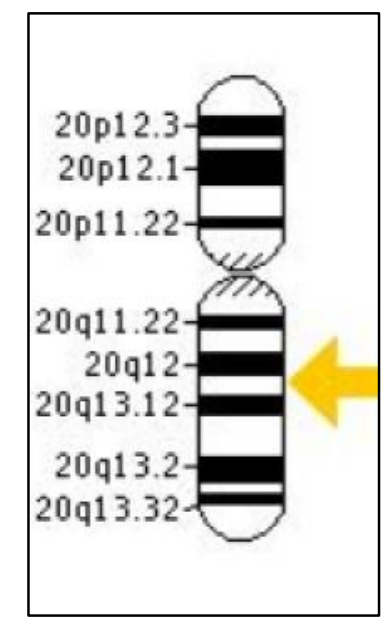

Ovaj mitohondrijalni enzim je prvi put opisan početkom 1970. godine, kada se verovalo da uključen samo u renalnu 24-hidroksilaciju $25(\mathrm{OH}) \mathrm{D}_{3}$ (Jones i sar., 2011). Međutim, enzim ima sposobnost multiple hidroksilacije ugljenka C-23 i C-24 na bočnim lancima kalcidiola $25(\mathrm{OH}) \mathrm{D}_{3}$ i metabolički aktivne forme kalcitriola. Poravnanjem dela aminokiselinske sekvence ovog enzima kod 57 vrsta, od košljoriba do čoveka, pokazan je visok stepen konzerviranosti rezidua, za veliki deo proteina (Jones i sar., 2011). Tokom 2010. godine je rasvetljena kristalna struktura proteina CYP24A1 kod pacova. CYP24A1 pacova je primarno 24-hidroksilaza, za razliku od humanog enzima koji ima mogućnost hidroksilacije i C-23 i C-24 pozicija (Jones i sar., 2011). Gotovo u isto vreme kada je rasvetljena uloga u hidroksilaciji vitamina D, pokazano je da je i CYP24A1 gen eksprimiran u mnogim, ako ne svim ciljnim ćelijama koje sadrže receptor za vitamin D, uključujući bubrege, kosti, intestinum itd. Ovakvi nalazi su vodili nekim pretpostavkama da je primarna uloga CYP24A1 da ograniči ili atenuira akciju kalcitriola na ciljne ćelije nakon inicijalne transkripcione aktivnosti u negativnoj 
povratnoj spregi (Jones i sar., 2011). Kloniranje CYP24A1 gena početkom 1990. godine je potvrdilo šablon ekspresije CYP24A1 u ciljnim ćelijama i inducibilnost supstratom, kalcitriolom. Povećanje količine metabolički aktivne forme vitamina D u ciljnim ćelijama može pokrenuti CYP24A1 posredovani metabolizam koji štiti ćelije od aktivacije VDR puta (Jones i sar., 2011). U eksperimentima u kojima su korišćeni CYP24A1 nokaut miševi, potvrđena je katabolička uloga enzima 24(OH)-aze. Nivo razlaganja kalcitriola je bilo dramatično redukovano i poluživot hormona u plazmi je bio povećan 10 puta (Jones i sar., 2011). Dakle postoji obilje dokaza da je reč o enzimu čija je normalna fiziološka uloga da kataboliše $25(\mathrm{OH}) \mathrm{D}_{3}$ u cilju sprečavanja eventualne aktivacije kalcitriola i/ili da degraduje kalcitriol unutar ciljnih ćelija da bi prekinuo njegovu biološku aktivnost (Jones i sar., 2011).

Kada je jasno ustanovljeno da je CYP24A1 ključni enzim za katabolizam vitamina $D$, postalo je očigledno da je reč o enzimu koji radi balansirano sa citohromom P450 familije, CYP27B1, koji ima ulogu u prevođenju $25(\mathrm{OH}) \mathrm{D}_{3}$ do kalcitriola u bubrezima, gde je njegova uloga prevashodno otkrivena, ali i u drugim ekstrarenalnim tkivima.

Činjenica da metabolički aktivna forma vitamina D ima antiproliferativno i pro-diferencirajuće dejstvo na nekoliko ćelijskih tipova in vivo i mnogim ćelijskim linijama in vitro, kao i činjenica da je u ćelijskim linijama prostate, kolona i dojke tokom tumorske progresije dokazano smanjenje CYP27B1 i povećanje CYP24A1 ekspresije, navode na pretpostavku da zapravo progresija kancera podrazumeva disfunkcionalni metabolizam vitamina D.

Postoji veliki broj tvrdnji da je CYP24A1 gen kandidat za potencijalnog onkogena (Jones i sar., 2011; Fischer i sar., 2009). Naime, povećana amplifikacija CYP24A1 gena je detektovana u karcinomu dojke i ovarijuma (Fischer i sar., 2009). Inhibicija 24-hidroksilaze u ćelijskim linijama ovarijalnih kancera intenzivira ćelijsku diferencijaciju i inhibiciju rasta posredovanu kalcitriolom, što je jedan od dokaza koji idu u prilog potencijalnoj onkogenoj funkciji CYP24A1 gena.

Interesantno je da je bazalni nivo ekspresije CYP24A1 veoma nizak (Roff i sar., 2008). Međutim, izvesne studije su pokazale da maligno tkivo ima značajno viši nivo ekspresije iRNK 24(OH)-aze u poređenju sa benignim tkivom (Fischer i sar., 2009; Jones i sar., 2011). Visok nivo iRNK CYP24A1 u malignom tkivu ukazuje 
na povećanu degradaciju i stoga smanjenu dostupnost kalcitriola što može voditi malignoj transformaciji.

Dobro je poznat značaj CYP24A1 u tretmanu karcinoma. Analozi vitamina D se koriste u hiperproliferativnim bolestima, kao što su psorijaza i kancer (Jones i sar., 2011). Efektivnost analoga vitamina D je ograničena indukcijom CYP24A1 u ciljnim ćelijama (npr. keratinocitima), uzrokujući rezistentnost na primenjeni lek (Jones i sar., 2011). Zabeleženo je da neke tumorske ćelije amplifikuju CYP24A1 gen u cilju postizanja selekcione prednosti nad okružujućim normalnim ćelijama (Jones i sar., 2011).

U humanim ćelijama prostate ekspresija CYP24A1 i CYP27B1 gena je regulisana epigenetičkim mehanizmima (Cross i sar., 2009). Tokom maligne progresije, promotor CYP27B1 je metilovan u epitelijalnim ćelijama, dok je promotor CYP24A1 demetilovan, što dovodi do pojačane degradacije niskog nivoa kalcitriola koji se još uvek produkuje. Takođe, sinteza kalcitriola od $25(\mathrm{OH}) \mathrm{D}_{3}$ se dešava u ovim ćelijama koje su tretirane inhibitorom metiltransferaze (Cross i Kallay, 2009). Neke studije naglašavaju i značaj mikrosredine (tumorske vs. prirodne) u regulaciji ekspresije CYP24A1: promotor CYP24A1 gena je bio hipermetilovan u endotelnim ćelijama nastalim od tumorskog tkiva, što nije bio slučaj kod endotelinih ćelija poreklom od normalnog tkiva (Cross i Kallay, 2009). Na prvi pogled, ovi rezultati deluju kontradiktorno u odnosu na fenomen zapažen u epitelijalnim ćelijama, što je dobar primer protektivne uloge sistema vitamina D (Cross i Kallay, 2009).

Razlika u ekspresiji hidroksilaza vitamina D tokom tumorske progresije, primećena kod pacijenata sa dijagnostikovanim kancerom kolona, je najverovatnije uzrokovana epigenetičkom regulacijom genske aktivnosti metilacijom/demetilacijom, kao i histonskom acetilacijom/deacetilacijom (Cross i Kallay, 2009). U kancerogenim lezijama nižeg stadijuma, CYP27B1 ekspresija je visoka u poređenju sa normalnom mukozom pacijenata bez kancera. Povećana sinteza i akumulacija kalcitriola u mukozi kolona bi bila odgovorna za povećanu ekspresiju CYP24A1 transkripta, kao i parakrine/autokrine inhibicije rasta tumorske ćelije. Pretpostavlja se da je tokom progresije kancera CYP27B1 inaktiviran epigenetičkim mehanizmima, dok je CYP24A1 aktiviran. S obzirom na 
mogućnost da modifikuju epigenetičke mehanizme, uzimanje folata i fitoestrogena bi moglo povećati ekspresiju CYP27B1 i redukovati enormno povećanje ekspresije kataboličkog CYP24A1. Ako bi transkripciona represija ekspresije CYP24A1 mogla biti menjana metilacionim agensima, pacijenti sa dijagnostikovanim uznapredovalim stadijumom kolorektalnog karcinoma bi mogli imati veliku korist od tretmana vitaminom D ili njegovim analozima (Cross i Kallay, 2009).

Činjenica da povećan nivo ekspresije CYP24A1 gena može biti glavni uzročnik deficijencije vitamina D i progresije bolesti, sugeriše da je reč o enzimu i genu koji predstavlja potencijalnu dobru metu za terapiju. Tokom prošle decenije je identifikovan i/ili sintetisan značajan broj inhibitora u cilju tretmana bolesti asociranih sa povećanim katabolizmom vitamina D: npr. visoko specifični CYP24A1 inhibitori, genistein i drugi (Jones i sar., 2011; Davis, 2009). Folati u ishrani takođe mogu inhibirati aktivnost CYP24A1 povećanjem metilacionog statusa promotorskog regiona i time smanjenjem ekspresije ovog gena (Davis, 2009).

Otkriće strukture enzima kod pacova će dati bolje uvide u višestruku funkcionalnost enzima i poboljšati razvoj druge generacije inhibitora. Stoga se sadašnje vreme smatra jako pogodnim za istraživanje CYP24A1 gena i enzima.

\subsubsection{Polimorfizmi u CYP24A1 genu}

$\mathrm{Na}$ osnovu podataka dostupnih u genomskim bazama podataka, identifikovan je oko 50 polimorfizama u CYP24A1 gen i tokom nekoliko poslednjih godina se ta lista značajno uvećava. Efekti ovih polimorfizama na enzimsku aktivnost su uglavnom slabo poznati ili potpuno nepoznati (Jones i sar., 2011).

Proksimalni region promotora CYP24A1 je bogat GC parovima (oko 71\% među prvih 550 nukleotida), te je pravi izazov sekvencirati ga i time objasniti nedostatak poznatih polimorfnih varijanti u ovom regionu (Roff i sar., 2008).

Funkcionalni efekti identifikovanih polimorfizama u CYP24A1 genu su uglavnom nejasni/nepoznati. Međutim, nekoliko skorije identifikovanih polimorfizama u CYP24A1 genu u promotorskom regionu egzona 1 imaju funkcionalni efekat na vezivanje za VDRE, in vitro transaktivaciju i izmenjenu 
ekspresiju gena in vivo (Holt i sar., 2010). SNP-ovi koji se nalaze u blizini ovog regiona (npr. rs4809960, rs2296241, rs2585428, rs6022999) se možda nalaze u neravnoteži vezanosti sa funkcionalnim polimorfizmima.

Jednom studijom je identifikovano 6 polimorfizama u promotoru CYP24A1 gena, koji utiču na vezivanje proteinskog receptora, sniženu transaktivaciju i sniženu ekspresiju CYP24A1 gena u in vivo uslovima (Roff i sar., 2008).

\subsubsection{1. rs2296241}

Polimorfizam rs2296241 predstavlja izmenu adenina guaninom u egzonu 4 CYP24A1 gena i reč je o sinonimnom polimorfizmu. Spada u evoluciono konzervirane polimorfizme (skor 0.99) (Holt i sar., 2010). Neke od prethodnih sudija pokazuju da je navedeni polimorfizam asociran sa smanjenim mortalitetom uzrokovanim kancerom prostate, ali ne i rizikom za nastanak karcinoma prostate (Holt i sar., 2010). Jedno od nedavno sprovedenih istraživanja nije ustanovilo postojanje asocijacije sa rizikom za nastanak kancera dojke (Dorjgochoo i sar., 2011). Kontradiktorni rezultati prisutni u literaturi su predstavljali glavni povod za izbor datog polimorfizma u CYP24A1 genu za našu studiju asocijacije sa oralnim karcinomom. 


\section{CILJEVI ISTRAŽIVANJA}


Mnogobrojni podaci ukazuju da i pored izloženosti značajnim faktorima rizika za nastanak oralnog skvamocelularnog karcinoma (npr. pušenje, alkohol, HPV infekcija) samo izvesni procenat osoba oboli od oralnog karcinoma, što ukazuje na značaj genetičke osnove u procesu oralne kancerogeneze. Na osnovu činjenica iznetih u uvodnom delu ove doktorske disertacije, može se zaključiti da vitamin D ima značajnu ulogu kao antikancerogeni agens, koji inhibitorno deluje na mnogobrojne molekule i signalne puteve koji su uključeni u progresiju kancerogeneze. Vitamin D ispoljava svoj biološki efekat nakon vezivanja za receptor za vitamin D, čije se sposobnosti ligandnog vezivanja ne razlikuju između normalnih i malignih ćelija u kojima je receptor eksprimiran. Receptor za vitamin D je kodiran VDR genom, u kom je identifikovan veliki broj polimorfizama nukleotidne sekvence, od kojih samo mali broj ima funkcionalni efekat. S obzirom na značaj koji SNP-ovi imaju u studijama asocijacije, postavlja se pitanje da li postojanje određenih genotipskih varijanti u VDR genu može biti u vezi sa podložnošću nastanka oralnog karcinoma ili asocirano sa kliničko patološkim odlikama bolesti i ukupnim preživljavanjem pacijenata. Kako su u metabolizam vitamina D uključeni enzimi kodirani CYP27B1 i CYP241A1 genima, od interesa je razmotriti potencijalnu vezu polimorfizama identifikovanih u ovim genima sa nastankom oralnog karcinoma. Na osnovu toga, postavljena je radna hipoteza, koja glasi: mutirane varijante analiziranih polimorfizama u VDR, CYP27B1 i CYP24A1 genima su asocirane sa etiološkim faktorima, kliničko patološkim karakteristikama i rizikom oboljevanja od oralnog skvamocelularnog karcinoma. Analizirani polimorfizmi i/ili haplotipovi su asocirani sa ishodom bolesti i ukupnim preživljavanjem pacijenata.

U cilju provere radne hipoteze, postavljeni su sledeći ciljevi istraživanja:

Utvrditi učestalosti genotipova i alela polimorfizama EcoRV, FokI, TaqI, ApaI, BsmI i rs11574085 u VDR genu, CYP27B1 (rs4646536) i CYP24A1 (rs2296241) genima $\mathrm{u}$ grupi pacijenata sa oralnim skvamocelularnim karcinomom i $\mathrm{u}$ kontrolnoj grupi; 
Utvrditi eventualno postojanje razlike $u$ distribuciji genotipova $i$ alela analiziranih polimorfizama između grupe pacijenata i kontrolne grupe zdravih osoba naše populacije odgovarajuće polne i starosne distribucije;

Ustanoviti da li postoji veza između genotipova proučavanih polimorfizama u VDR, CYP27B1 i CYP24A1 genima sa etiološkim faktorima, kao što su: pušenje, konzumiranje alkohola i oralna higijena i kliničko patološkim karakteristikama: veličinom tumora, stadijumom bolesti, nodalnim statusom, nukleusnim i histološkim gradusom;

Identifikacija LD blokova. Odrediti učestalosti haplotipova u grupi pacijenata i kontrolnoj grupi i utvrditi eventualno postojanje razlike u distribuciji haplotipova između analiziranih grupa;

Utvrditi postojanje asocijacije između identifikovanih haplotipova i rizika za razvoj oralnog skvamocelularnog karcinoma;

Ispitati povezanost polimorfizama u analiziranim genima i/ili haplotipova sa ishodom bolesti, odnosno sa ukupnim preživljavanjem pacijenata. 
3. MATERIJAL I METODE 
Eksperimentalni deo doktorske disertacije je realizovan u Laboratoriji za molekularnu genetiku Instituta za medicinska istraživanja Vojnomedicinske akademije u Beogradu.

Etički aspekti. Osobe čiji je biološki materijal korišćen u istraživačke svrhe su dale informisani pristanak za učešće u studiji. Etički komitet Vojnomedicinske akademije u Beogradu je odobrio izođenje ove studije u skladu sa Helsinškom deklaracijom (2008).

\subsection{Studijska grupa}

U studiju je uključeno 110 pacijenata sa dijagnostikovanim oralnim skvamocelularnim karcinomom jezika i poda usne duplje, operisanih na Klinici za maksilofacijalnu hirurgiju, Vojnomedicinske akademije u Beogradu. Grupa pacijenata je obuhvatala 81 (73.6\%) muškaraca i 29 (26.4\%) žena, starosti od 39-80 godina (medijana 58 godina). Pacijenti nisu primali hemioterapiju, a svi su bili podvrgnuti radioterapiji nakon operacije. Kod 83 (75.5\%) pacijenata je dijagnostikovan tumor u uznapredovalom III stadijumu, dok je 27 (24.5\%) pacijenata imalo tumor u II stadijumu bolesti. Metastaze limfnih čvorova su bile prisutne kod 87 (79.1\%) pacijenta, tj. bili su pozitivnog nodalnog statusa $(\mathrm{N}+)$, a 23 (20.9\%) pacijenta je bilo negativnog nodalnog statusa. Udaljene metastaze nisu detektovane. Minimalno vreme praćenje pacijenta nakon operacije je bilo 28, a maksimalno 100 meseci.

Kontrolnu grupu je činilo 122 osobe, dobrovoljnih davaoca krvi, koji su se javili Institutu za transfuziologiju Vojnomedicinske akademije u Beogradu. Osobe koje su činile kontrolnu grupu su iste populacije sa teritorije Srbije, odgovarajuće starosne i polne distribucije, bez prethodno dijagnostikovanih kancera u istoriji bolesti.

Učesnici studijske grupe su intervjuisani usmenim putem, čime su dobijene informacije o njihovom pušačkom statusu odnosno korišćenju alkohola. Kao bivši pušači su definisane osobe koje su prestale sa pušenjem najmanje godinu dana pre postavljanja dijagnoze. Osobe koje su svakodnevno pušile, godinu dana ili duže pre 
postavljanja dijagnoze su klasifikovane kao pušači. Ukoliko je osoba unosila više od 20 alkoholnih jedinica sedmično ( 1 jedinica=22g etanola), klasifikovana je kao alkoholičar, a kao bivši alkoholičar ukoliko je prestala sa konzumiranjem alkohola minimum godinu dana pre postavljanja dijagnoze. Zbog ograničenog broja nepušača, odnosno nealkoholičara, bivši pušači i nepušači, odnosno bivši alkoholičari i nealkoholičari su spojeni u jednu grupu u daljoj analizi.

Oralna higijena u grupi pacijenata je procenjivana kao loša ili dobra na osnovu odgovarajućih standardnih kriterijuma od strane iskusnih stomatologa.

\subsection{Biološki uzorci i izolacija DNK}

Uzorci tumorskog tkiva su dobijeni neposredno po izvršenoj operaciji, nakon čega su smrznuti na $-20^{\circ} \mathrm{C}$ u tečnom azotu i čuvani do početka izolacije DNK. Patološkom analizom je izvršena TNM klasifikacija tumorskog tkiva (UICC TNM klasifikacija, VI izdanje) nakon urađene disekcije tumorskog od nekrotičnog i normalnog tkiva. Od učesnika kontrolne grupe je korišćena periferna krv, koja je nakon uzimanja čuvana na temperaturi od $-20^{\circ} \mathrm{C}$, uz prisustvo antikoagulansa heparina, do početka izolacije DNK.

Iz uzoraka tumorskog tkiva, DNK je izolovana korišćenjem TRIzol reagensa (Invitrogen, Nemačka) prema uputstvu proizvođača. Ukratko, na prethodno dobro homogenizovan deo tumorskog tkiva se dodaje $1 \mathrm{ml}$ TRIzol reagensa i inkubira na sobnoj temperaturi u trajanju od $5 \mathrm{~min}$ da bi se obezbedila potpuna disocijacija nukleoproteinskog kompleksa. Uzorci se potom centrifugiraju na 12 000g/15 min na temperaturi od $+4^{\circ} \mathrm{C}$. Nakon centrifugiranja se uočavaju tri faze: prva bezbojna vodena faza koja sadrži RNK, interfaza i donja crvena organska fenol-hloroformska faza. DNK se precipitira iz interfaze i organske faze dodavanjem etanola, inkubiranjem u trajanju od 2-3 minuta na sobnoj temperaturi, nakon čega se vrši centrifugiranje. Nakon odlivanja fenol-etanolskog supernatanta, DNK se „pere“ u $0.1 \mathrm{M}$ Na-citratu rastvorenim u 10\% etanolu. Sledi inkubacija 30 minuta na sobnoj temperaturi, centrifugiranje i odbacivanje supernatanta. DNK pelet se 
resuspenduje u 75\% etanolu i potom centrifugira na 2 000g/5 min. Nakon odbacivanja supernatanta, izolovana DNK se suši na sobnoj temperaturi i konačno rastvara u $8 \mathrm{mM} \mathrm{NaOH}$.

Iz uzoraka periferne krvi kontrolne grupe, DNK je izolovana na aparatu AbiPrism 6100 Nucleic Acid PrepStation (Applied Biosystems, SAD) uz korišćenje BloodPrep kita (Applied Biosystems, SAD), prema pratećem protokolu. Nakon pripreme uzoraka i inkubacije sa digestionim puferom i proteinazom $\mathrm{K}$ na $65^{\circ} \mathrm{C} \mathrm{u}$ trajanju od $10 \mathrm{~min}$, uzorci se nanose na odgovarajuću ploču za izolaciju. Aparat za izolaciju DNK radi po principu vakuma koji povlači sadržaj bunarića na ploči i odbacuje ga, pri čemu DNK zaostaje i vezuje se za specijalno dizajniranu membranu od staklenih vlakana, koja se nalazi u osnovi bunarića. Nakon dodavanja rastvora koji sadrži etanol i precipitiranja izolovane DNK na membrani, vrši se eluiranje odgovarajućim puferima, nakon čega se konačno dobija izolovana DNK u visokom prinosu.

Izolovana DNK je nakon provere kvaliteta i čistoće i određivanja koncentracije čuvana na temperaturi od $-20^{\circ} \mathrm{C}$, do početka daljeg rada.

\subsection{Provera kvaliteta i koncentracije izolovane DNK}

Kvalitet izolovane genomske DNK je proveravan na 1\% agarozi bojenoj etidijum-bromidom čija je finalna koncentracija u rastvoru bila $5 \mu \mathrm{g} / \mathrm{ml}$. Elektroforeza se odvijala u 0.5 TBE puferu pri struji od $40 \mathrm{~mA}$ i naponu od $80 \mathrm{~V} \mathrm{u}$ trajanju od $20 \mathrm{~min}$. Intaktnost i kvalitet genomske DNK je analizirana pod UV svetlošću transiluminatora (Pharmacia LKB, Švedska).

Koncentracija DNK u uzorku, kao i čistoća izolata je određena korišćenjem Gene Quant spektrofotometra (Pharmacia LKB, Švedska) merenjem apsorbance na talasnoj dužini od $260 \mathrm{~nm}$. Koncentracija DNK je računata primenom formule:

$$
c[\mu g / \mu l]=\frac{A 260 \times R \times F \times O P}{1000}
$$

gde je:

A260 - apsorbanca uzorka na $260 \mathrm{~nm}$ 
R-razblaženje (100 puta)

F- faktor konverzije za dvolančanu DNK $(\mathrm{F}=50)$

OP- optički put svetlosti (debljina zid kivete, u našem slučaju $1 \mathrm{~cm}$ )

Čistoća izolovane DNK je procenjena odnosom apsorbanci (R) merenih na $260 \mathrm{~nm}$ i $280 \mathrm{~nm}$. U svim uzorcima, odnos apsorbanci je bio $\mathrm{R} \geq 1.6$, što ukazuje na relativno visok stepen čistoće izolovane DNK koja nije kontaminirana proteinima.

\subsection{Lančana reakcija polimerizacije}

Lančanom reakcijom polimerizacije (engl. Polymerase Chain Reaction- PCR) su amplifikovani ciljni regioni VDR gena, koji sadrže polimorfizam nukleotidne sekvence od interesa. Sekvence prajmera su bile poznate od ranije (Tabela 4.) (Povey i sar., 2007; Vupputuri i sar., 2006; Haghpanah i sar., 2007).

Tabela 4. Sekvence korišćenih prajmera za amplifikaciju ciljnih regiona VDR gena koji sadrže SNP od interesa

\begin{tabular}{|c|c|c|}
\hline Gen & $\begin{array}{l}\text { Polimorfizam } \\
\text { (Ref SNP) }\end{array}$ & Sekvence forward i reverse prajmera \\
\hline & $\begin{array}{c}\text { EcoRV } \\
\text { (rs4516035) }\end{array}$ & $\begin{array}{l}\text { F: 5'-CCT CCT CTG TAA GAG GCG AAT AGC GAT-3' } \\
\text { R: 5'-GGA CAG GTG AAA AAG ATG GGG TTC-3' }\end{array}$ \\
\hline$\simeq$ & $\begin{array}{l}\text { FokI } \\
(\mathrm{rs} 2228570)\end{array}$ & $\begin{array}{l}\text { F: 5'-AGC TGG CCC TGG CAC TGA CTC TGC TCT-3' } \\
\text { R: 5'-ATG GAA ACA CCT TGC TTC TTC TCC CTC-3' }\end{array}$ \\
\hline D & $\begin{array}{c}\text { TaqI } \\
\text { (rs731236) }\end{array}$ & $\begin{array}{l}\text { F: 5'-CAG AGC ATG GAC AGG GAG C -3' } \\
\text { R: 5'-AGG AGA GGC AGC GGT ACT G-3' }\end{array}$ \\
\hline & $\begin{array}{c}\text { ApaI } \\
\text { (rs7975232) }\end{array}$ & $\begin{array}{l}\text { F: 5'-AGC AGA GCA GAG TTC CAA GC-3' } \\
\text { R: 5'-GTG AGG AGG GCT GCT GAG TA-3' }\end{array}$ \\
\hline
\end{tabular}


U PCR reakciju je dodavano 200ng izolovane genomske DNK. Korišćen je 2x AmpliTaqGold Master Mix (Applied Biosystems, SAD). Temperature hibridizacije prajmera su se razlikovale u zavisnosti od analiziranih polimorfizama.

Uspešnost amplifikacije ciljnog regiona je proveravana na 2\% agarozi visoke rezolucije (Serva, Nemačka), bojenoj etidijum-bromidom. Elektroforeza se odvijala u 0.5 TBE puferu, pri struji od $40 \mathrm{~mA}$ i naponu od $80 \mathrm{~V}$ u trajanju od 15 minuta. Gel je analiziran pod UV svetlošću transiluminatora (Pharmacia LKB, Švedska).

\subsection{Analiza polimorfizma dužine restrikcionih fragmenata}

Konvencionalna PCR reakcija je praćena analizom polimorfizama dužine restrikcionih fragmenata (engl. Restriction Fragment Length PolymorphismRFLP). Nakon amplifikacije gena, u cilju utvrđivanja genotipa analiziranih polimorfizama nukleotidne sekvence, dobijeni amplifikati su tretirani odgovarajućim restrikcionim enzimima, Fast digest (Fermentas, Nemačka) prema priloženom uputstvu proizvođača. Polimorfizmi u VDR genu: EcoRV (rs4516035), FokI (rs2228570), TaqI (rs731236) i ApaI (rs7975232) su genotipizirani RFLP metodom i imenovani su prema restrikcionim enzimima koji se koriste u njihovoj identifikaciji. Nakon inkubacije na optimalnoj temperaturi, specifičnoj za svaki od primenjenih enzima, restrikcioni fragmenti su analizirani na $10 \%$ poliakrilamidnom gelu. Elektoroforeza se odvijala u 0.5 TBE puferu pri struji od 10-20 mA i naponu od 150-200 V u trajanju od 90 min. Po isteku elektroforeze, poliakrilamidni gel je bojen srebro nitratom. Ukratko: nakon završene elektroforeze gel se najpre fiksira 10\% etanolom nakon čega se vrši obezbojavanje 1\% azotnom kiselinom. Nakon ispiranja u destilovanoj vodi, za bojenje gela se koristi $0.2 \%$ rastor srebro nitrata, a kao razvijač boje $0.1 \mathrm{M} \mathrm{Na}_{2} \mathrm{CO}_{3}$ sa $0.02 \%$ formaldehidom. Nakon bojenja u trajanju od 20 min na tamnom, vrši se ispiranje destilovanom vodom. Konačno, gel se fiksira 10\% sirćetnom kiselinom.

$\mathrm{Na}$ osnovu dužine restrikcionih fragmenata je određivan genotip analiziranog polimorfizma. Za određivanje veličine restrikovanih fragmenata su 
korišćeni molekulski markeri (BioRAD, SAD). Genotipovi su obeležavani standardnom nomenklaturom prema kojoj se velikim slovom označava odsustvo, a malim slovom prisustvo restrikcionog mesta. Detalji o analiziranim polimorfizmima u VDR genu, kao i veličine restrikcionih fragmenata su predstavljeni tabelom 5 .

Tabela 5. Detalji o polimorfizmima u VDR genu genotipiziranih RFLP metodom

\begin{tabular}{|c|c|c|c|c|}
\hline Gen & Lokacija & $\begin{array}{c}\text { Polimorfizam } \\
\text { (Ref SNP) }\end{array}$ & Enzim & Alel/veličina \\
\hline VDR EcoRV & $\begin{array}{l}\text { Promotor } \\
-1012\end{array}$ & $\begin{array}{c}\mathrm{T} / \mathrm{C} \text { ili e/E } \\
\text { (rs4516035) }\end{array}$ & EcoRV & $\begin{array}{l}\text { wt: } 152 \mathrm{bp}+27 \mathrm{bp} \\
\text { mut: } 179 \mathrm{bp}\end{array}$ \\
\hline VDR FokI & $\begin{array}{l}\text { Egzon } 2 \\
+27823\end{array}$ & $\begin{array}{c}\mathrm{T} / \mathrm{C} \text { ili f/F } \\
(\mathrm{rs} 2228570)\end{array}$ & FokI & $\begin{array}{l}\text { wt: } 265 b p \\
\text { mut: } 196 b p+69 b p\end{array}$ \\
\hline VDR TaqI & $\begin{array}{l}\text { Egzon } 9 \\
+61938\end{array}$ & $\begin{array}{l}\mathrm{T} / \mathrm{C} \text { ili T/t } \\
\text { (rs731236) }\end{array}$ & TaqI & $\begin{array}{l}\text { wt: } 454 \mathrm{bp} \\
\text { mut: } 293 \mathrm{bp}+161 \mathrm{bp}\end{array}$ \\
\hline VDR ApaI & $\begin{array}{l}\text { Intron } 8 \\
+61888\end{array}$ & $\begin{array}{c}\text { C/A ili a/A } \\
\text { (rs7975232) }\end{array}$ & ApaI & $\begin{array}{l}\text { wt: } 403 \mathrm{bp}+298 \mathrm{bp} \\
\text { mut: } 701 \mathrm{bp}\end{array}$ \\
\hline
\end{tabular}

wt: divlji homozigot; mut: mutirani homozigot 


\subsection{Real-Time PCR alelska diskriminacija}

Polimorfizmi u VDR genu: BsmI (rs1544410) i rs11574085 kao i polimorfizmi CYP27B1 gena (rs464653) i CYP24A1 gena (rs2296241) su genotipizirani alelskom diskriminacijom na Real-Time PCR 7300 (Applied Biosystems, SAD). Korišćeni su komercijalno dostupni eseji: TaqMan SNPs Genotyping Assay (Applied Biosystems, SAD) u koncentraciji 40x i 2x Universal TaqMan MasterMix (Applied Biosystems, SAD).

Svaki TaqMan esej pored odgovarajućih prajmera sadrži i dve probe, komplementarne sa ciljnom sekvencom genomske DNK koja sadrži SNP od interesa, pri čemu se dve probe međusobno razlikuju za samo jedan nukleotid koji je komplementaran divljem, odnosno mutiranom alelu. TaqMan probe su na 5' kraju obeležene fluorescentnim bojama VIC i FAM, koje ne fluoresciraju u intaktnom stanju zahvaljujući energetskom prihvatanju fluorescence od strane „prigušivača“ (engl. quencher) koji se nalazi na 3' kraju probe. Nakon hibridizacije prajmera i komplementarnog sparivanja probe sa ciljnom sekvencom, Taq polimeraza vrši ekstenziju i istovremeno iseca komplementrno sparenu TaqMan probu, čime se fluorescentna boja kojom je proba bila obeležena oslobađa u rastvor. S obzirom da se nakon isecanja proba više ne nalazi u intaktnom stanju i pod uticajem prigušivača na 3' kraju, počinje da fluorescira u rastvoru. Intenzitet fluoresciranja odgovara količini amplifikata u reakciji. Dakle, tokom odvijanja PCR-a u realnom vremenu meri se promena intenziteta fluorescence boja kojima su probe obeležene. Prisustvo divljeg ili mutiranog homozigota rezultira detektovanjem samo jedne fluorescentne boje u uzorku, dok se u slučaju heterozigota registruju obe fluorescentne boje. Alel specifične fluorescentne krive su detektovane i analizirane korišćenjem 7500 System SDS softvera (Applied Biosystems, SAD).

Detalji o polimorfizmima analiziranim Real-Time PCR alelskom diskriminacijom su predstavljeni u Tabeli 6. 
Tabela 6. Detalji o polimorfizmima u VDR, CYP27B1 i CYP24A1 genima genotipiziranih Real Time PCR metodom

\begin{tabular}{|lccc|}
\hline \hline \multicolumn{1}{|c}{ Gen } & Lokacija & $\begin{array}{c}\text { Polimorfizam } \\
\text { (Ref SNP) }\end{array}$ & ID TaqMan Assay \\
\hline \hline VDR BsmI & $\begin{array}{c}\text { Intron } 8 \\
+60890\end{array}$ & $\begin{array}{c}\text { G/A ili b/B } \\
(\text { rs1544410) }\end{array}$ & C_8716062_10 \\
\hline VDR & Intron 8 & $\begin{array}{c}\text { A/T } \\
(\mathrm{rs} 11574085)\end{array}$ & C_30742487_10 \\
CYP27B1 & $\begin{array}{c}\text { Intron 6 } \\
+2838\end{array}$ & $\begin{array}{c}\text { C/T } \\
(\mathrm{rs} 4646536)\end{array}$ & C_25623453_10 \\
CYP24A1 & Egzon 4 & $\begin{array}{c}\text { A/G } \\
(\mathrm{rs} 2296241)\end{array}$ & C_1915656_30 \\
\hline \hline
\end{tabular}

ID TaqMan Assay-identifikacioni broj eseja

\subsection{Analiza haplotipova}

Vrednosti neravnoteže vezanosti (LD) su računate i grafički predstavljene za sve analizirane parove polimorfizama u VDR genu pomoću programa Haploview 4.2. (Barret i sar., 2005). Za identifikaciju haplotipskog bloka je korišćena opcija solid spine block definition, prema kojoj se krajnji članovi haplotipskog bloka nalaze $\mathrm{u}$ jakom LD-u, dok se između njih nalaze članovi koji međusobno mogu biti $\mathrm{u}$ slabijem LD-u. Haploview program pruža i mogućnost računanja učestalosti haplotipova u analiziranoj grupi-populaciji nesrodnika, primenom matematičkog Expectation Maximisation (EM) algoritma (Fallin i Schork, 2000).

Asocijacija haplotipova sa ukupnim preživljavanjem je urađena pomoću programa Thesias 3.1. (Tregouet i sar., 2007). Naime, primenom Cox-regression hazard risk modela se procenjuje Hazard Ratio (HR) sa nivoom poverenja (engl. Confidence Interval-CI) od 95\%. U osnovi se koristi matematički Stohastic Expectation Maximisation (SEM) algoritam (Tregouet i sar., 2004; Zaykin i sar., 2002). 


\subsection{Statistička analiza}

Dobijeni rezultati su obrađeni statističkim programom SPSS (verzija 17.00, IBM SPSS Inc., SAD). Tablice kontingencije su analizirane primenom hi-kvadrat $\left(\chi^{2}\right)$ ili Fisher testa u slučaju kada je očekivana učestalost bila manja od 5\%. Primenom

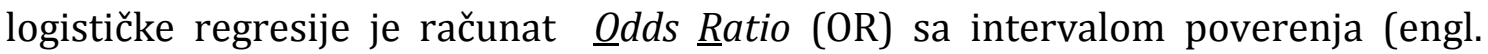
Confidence Interval- CI) od 95\%.

Ukupno preživaljvanje je procenjivano Kaplan-Meier Survival metodom. Kaplan-Meier krive preživljavanja su međusobno poređene log-rank testom. Hazard Ratio (HR) je računat Cox-proporcionalnom hazard regresionom analizom sa 95\% nivoom poverenja. Sve varijable koje su u univarijantnoj analizi bile statistički značajne su analizirane udruženo u multivarijantnoj Cox-regresionoj analizi. U Cox-ovom modelu je korišćen forward stepwise method, kojim su se uklanjale promenljive sa verovatnoćom $\mathrm{p}<0.1$.

Sve prikazane $\mathrm{p}$ vrednosti su bile two-sided i asocijacije su smatrane statistički značajnim ukoliko je p vrednost bila manja od 0.05 . 
4. REZULTATI 
Poglavlje rezultati je podeljeno u šest delova, pri čemu je u prvom delu predstavljena analiza proučavanih polimorfizama u grupi pacijenata sa oralnim karcinomom i u kontrolnoj grupi. U drugom delu su predstavljeni rezultati povezanosti polimorfizama sa etiološkim i kliničko patološkim odlikama grupe pacijenata. Rezultati analize haplotipova su predstavljeni u trećem delu, dok se rezultati analize ukupnog preživljavanja nalaze u četvrtom delu. U petom delu je predstavljena analiza promenljivih relevantnih za ukupno preživljavnje i u šestom delu analiza asocijacije haplotipova i preživljavanja pacijenata.

\subsection{Analiza polimorfizama u VDR, CYP27B1 i CYP24A1 genima}

Analiza zastupljenosti genotipova proučavanih polimorfizama u VDR genu između OSCC pacijenata i kontrolne grupe je pokazala da postoji statistički značajna razlika u učestalosti VDR genotipova za ApaI ( $p=0.013, \chi^{2}$ test), EcoRV ( $p=0.002, \chi^{2}$ test) i BsmI polimorfizam ( $p=0.025, \chi^{2}$ test) (Tabela 7., Slika 24.). Što se tiče preostalih analiziranih polimorfizama VDR gena $\mathrm{u}$ studiji, razlike $\mathrm{u}$ učestalosti između OSCC i kontrolne grupe nisu pronađene (Tabela 7., Slika 24.) i p vrednosti za preostale polimorfizme su iznosile: FokI ( $p=0.293, \chi^{2}$ test), TaqI $\left(p=0.123, \chi^{2}\right.$ test $)$ i rs11574085 ( $p=0.641$, Fisher test).

Interesantno je napomenuti da u slučaju BsmI polimorfizma nije registrovano prisustvo mutiranog BB genotipa u grupi pacijenata sa oralnim karcinomom, dok je zastupljenost BB genotipa u kontrolnoj grupi iznosila 2.4\%. Takođe je zabeleženo odsustvo mutirane TT homozigotne varijante u slučaju rs11574085 polimorfizma u grupi pacijenata, kao i u kontrolnoj grupi. 
Tabela 7. Distribucija genotipova analiziranih polimorfizama u VDR genu u OSCC i kontrolnoj grupi

\begin{tabular}{|c|c|c|c|c|}
\hline Gen/SNP & Genotip & $\frac{\text { OSCC }}{\mathbf{N}}$ & $\frac{\text { Kontrole }}{\mathbf{N}}$ & $\mathbf{p}^{*}$ \\
\hline VDR & ee & 35 & 34 & \\
\hline \multirow[t]{2}{*}{ EcoRV } & $\mathrm{Ee}$ & 62 & 51 & 0.002 \\
\hline & $\mathrm{EE}$ & 13 & 37 & \\
\hline VDR & $\mathrm{ff}$ & 32 & 46 & \multirow{3}{*}{0.293} \\
\hline \multirow[t]{2}{*}{ FokI } & Ff & 67 & 62 & \\
\hline & $\mathrm{FF}$ & 11 & 14 & \\
\hline VDR & TT & 41 & 59 & \multirow{3}{*}{0.123} \\
\hline \multirow[t]{2}{*}{ TaqI } & $\mathrm{Tt}$ & 58 & 48 & \\
\hline & $\mathrm{tt}$ & 11 & 15 & \\
\hline VDR & aa & 31 & 29 & \multirow{3}{*}{0.013} \\
\hline \multirow[t]{2}{*}{ ApaI } & $\mathrm{Aa}$ & 52 & 41 & \\
\hline & AA & 27 & 52 & \\
\hline VDR & $\mathrm{bb}$ & 39 & 59 & \multirow{3}{*}{0.025} \\
\hline BsmI & $\mathrm{Bb}$ & 71 & 60 & \\
\hline & $\mathrm{BB}$ & 0 & 3 & \\
\hline \multirow{3}{*}{$\begin{array}{c}\text { VDR } \\
\text { rs11574085 }\end{array}$} & AA & 102 & 110 & \multirow{3}{*}{0.641} \\
\hline & AT & 8 & 12 & \\
\hline & TT & I & I & \\
\hline
\end{tabular}




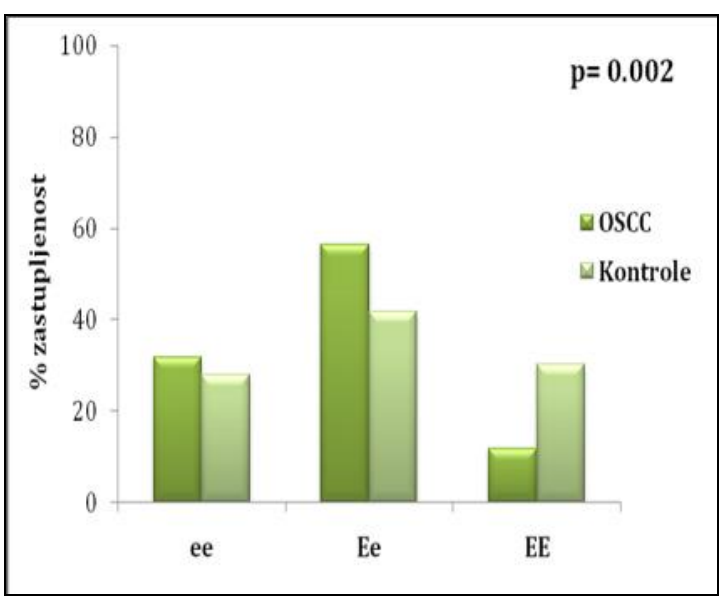

a)

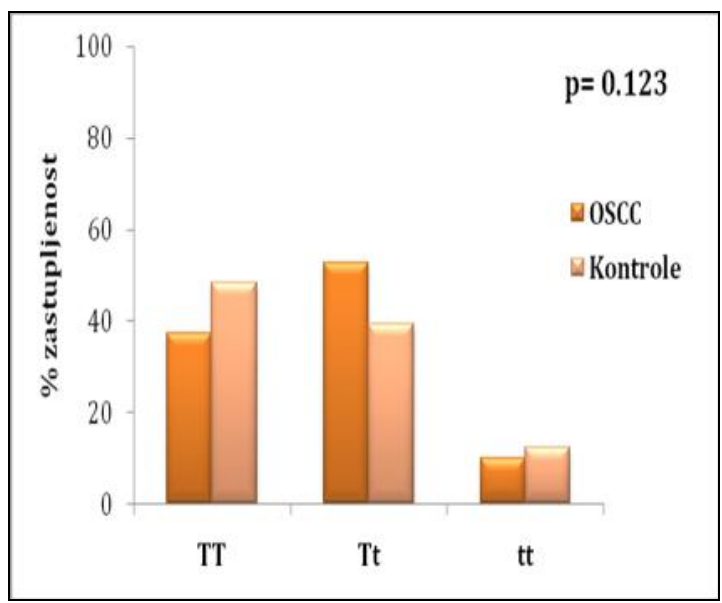

c)

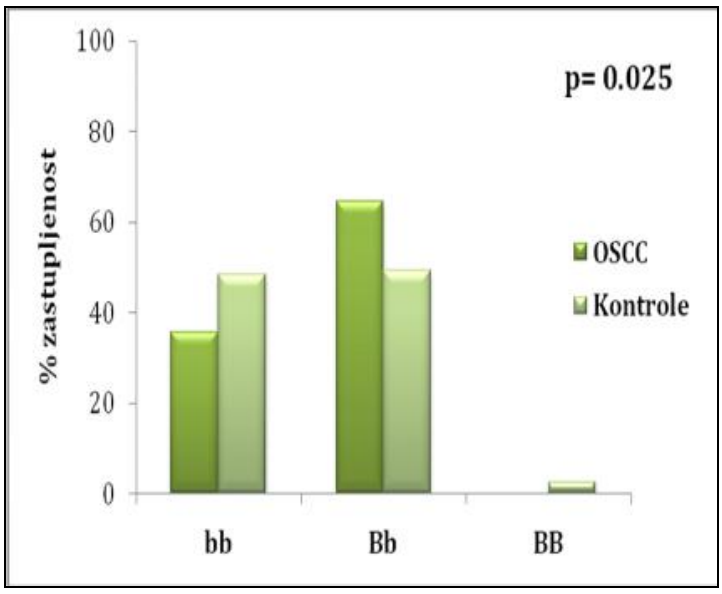

e)

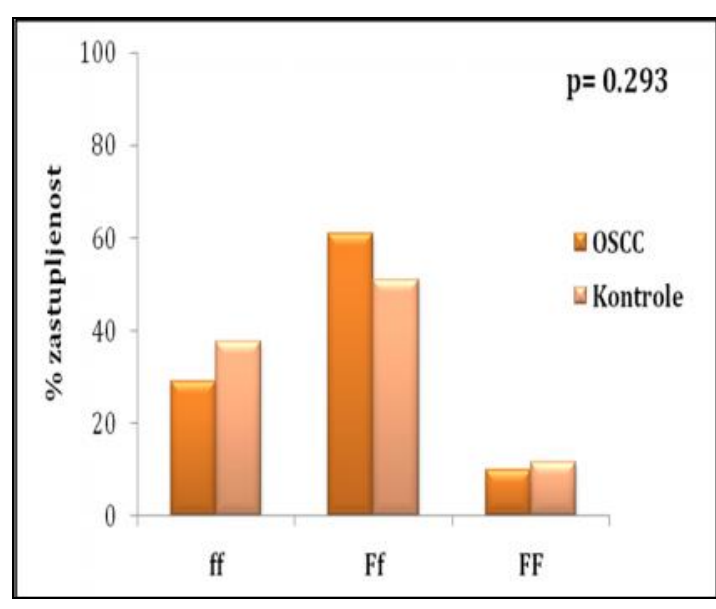

b)

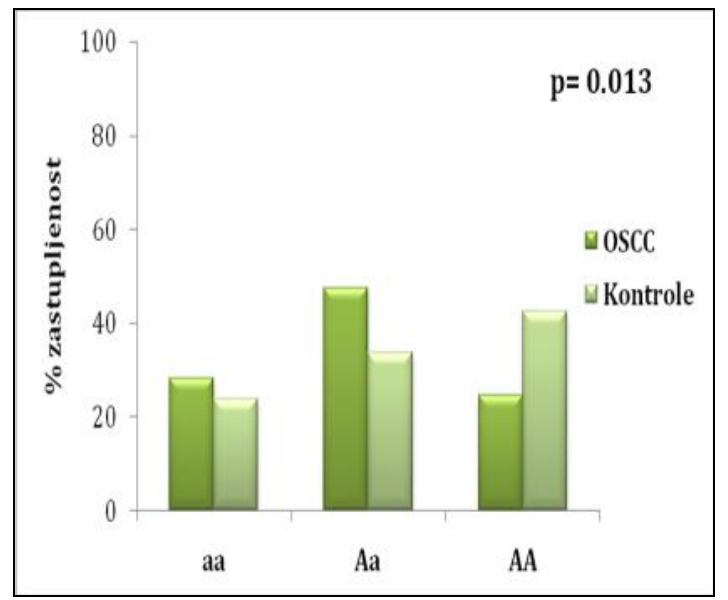

d)

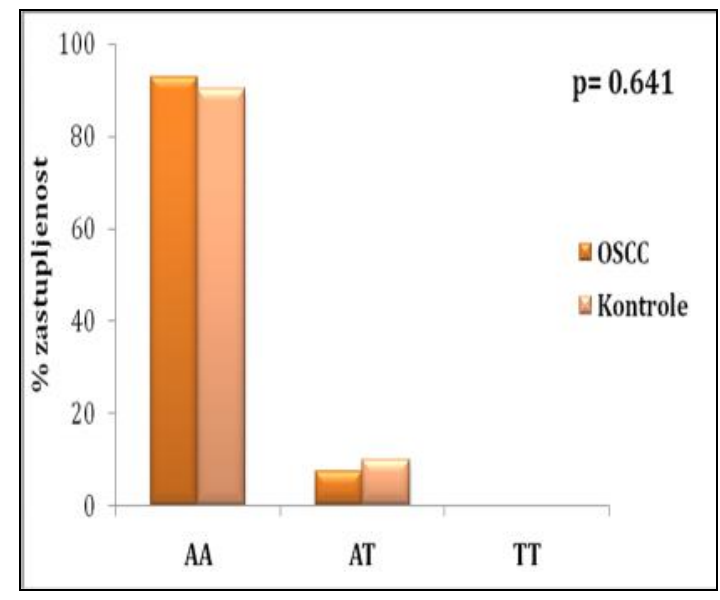

f)

Slika 24. Procentualna zastupljenost genotipova proučavanih polimorfizama u VDR genu u OSCC i kontrolnoj grupi za polimorfizme: a) EcoRV b) FokI c) TaqI d) ApaI e) BsmI f) rs11574085 
Učestalosti alela proučavanih polimorfizama VDR gena su predstavljene $\mathrm{u}$ Tabeli 8. Zapaženo je postojanje značajne razlike u distribuciji alela EcoRV polimorfizma ( $\mathrm{p}=0.019, \chi^{2}$ test) (Tabela 8., Slika 25.) i alela ApaI polimorfizma $\left(p=0.019, \chi^{2}\right.$ test) (Tabela 8., Slika 26.) između grupe pacijenata sa dijagnostikovanim oralnim karcinomom i kontrolne grupe. Za preostale analizirane polimorfizme, nije zabeleženo postojanje razlike u zastupljenosti alela (Tabela 8.).

Tabela 8. Učestalost alela proučavanih polimorfizama VDR gena u OSCC i kontrolnoj grupi

\begin{tabular}{|c|c|c|c|c|}
\hline \multirow{2}{*}{ Gen/SNP } & \multirow{2}{*}{ Alel } & OSCC & Kontrole & \multirow{2}{*}{$\mathbf{p}^{*}$} \\
\hline & & $\mathbf{N}$ & $\mathbf{N}$ & \\
\hline VDR & $\mathbf{e}$ & 132 & 120 & \multirow{2}{*}{0.019} \\
\hline EcoRV & $\mathbf{E}$ & 88 & 124 & \\
\hline VDR & f & 132 & 154 & \multirow{2}{*}{0.490} \\
\hline FokI & $\mathbf{F}$ & 88 & 90 & \\
\hline VDR & $\mathbf{T}$ & 141 & 166 & \multirow{2}{*}{0.370} \\
\hline TaqI & $\mathbf{t}$ & 79 & 78 & \\
\hline VDR & $\mathbf{a}$ & 114 & 100 & \multirow{2}{*}{0.019} \\
\hline ApaI & A & 106 & 144 & \\
\hline VDR & b & 150 & 178 & \multirow{2}{*}{0.260} \\
\hline BsmI & B & 70 & 66 & \\
\hline VDR & $\mathbf{A}$ & 211 & 232 & \multirow{2}{*}{0.669} \\
\hline rs11574085 & $\mathbf{T}$ & 9 & 12 & \\
\hline
\end{tabular}

*Vrednosti $\mathrm{p}<0.05$ su podebljane 
a)

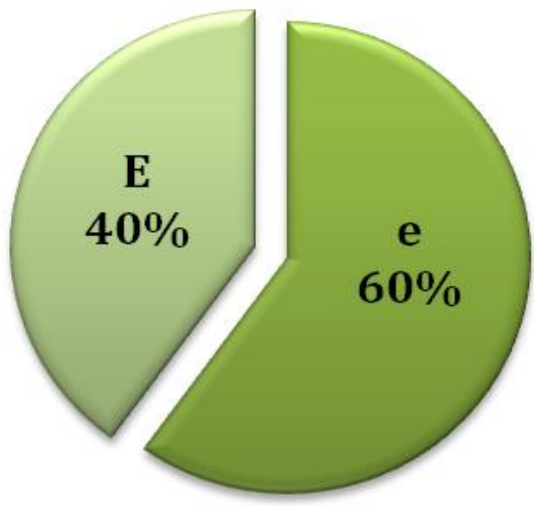

b)

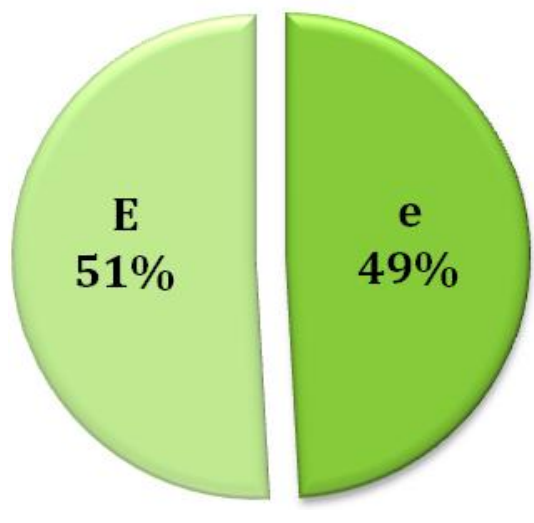

Slika 25. Procentualna zastupljenost alela EcoRV polimorfizma VDR gena u OSCC i kontrolnoj grupi a) OSCC b) kontrole

a)
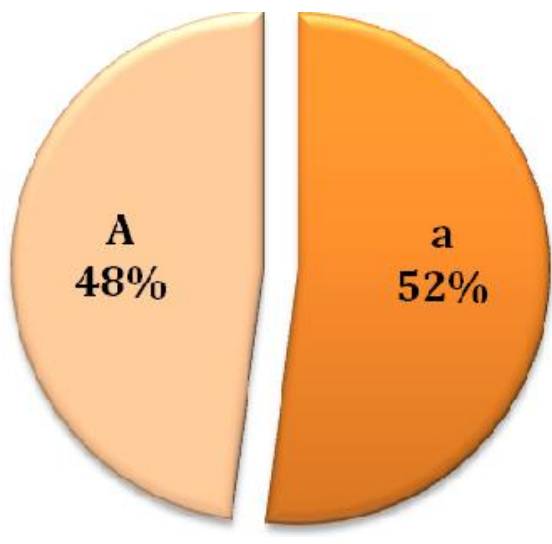

b)

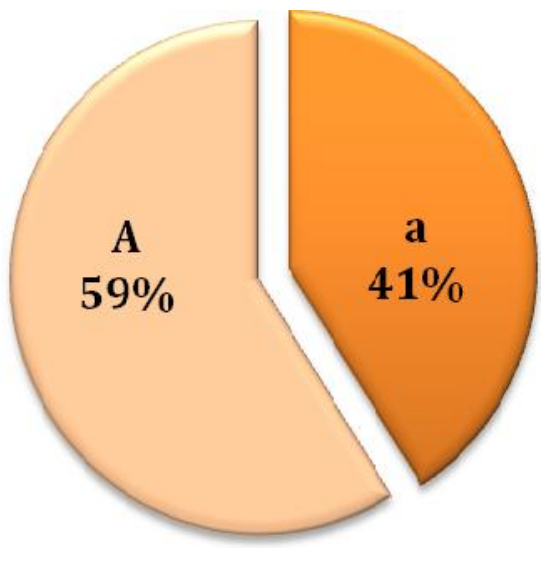

Slika 26. Procentualna zastupljenost alela ApaI polimorfizma VDR gena u OSCC i kontrolnoj grupi a) OSCC b) kontrole

Stratifikovana analiza u odnosu na pol je pokazala postojanje značajne razlike $u$ distribuciji genotipova EcoRV polimorfizma pacijenata muškog pola i kontrolne grupe istog pola $\left(\mathrm{p}=0.003, \chi^{2}\right.$ test), dok za isti polimorfizam nije registrovana razlika između pacijenata ženskog pola i kontrolne grupe istog pola $\left(\mathrm{p}=0.972, \chi^{2}\right.$ test). Stratifikacija prema polu za BsmI polimorfizam je pokazala postojanje značajne razlike između pacijenata muškog pola i kontrolne grupe istog pola ( $p=0.003, \chi^{2}$ test), dok značajnost nije nađena kod pripadnika ženskog pola između analiziranih grupa. Za preostale polimorfizme u VDR genu, stratifikovana analiza prema polu nije dala rezultate sa nivoom statističke značajnosti. 
Kada je reč o analiziranim polimorfizmima $u$ genima uključenim $u$ metabolizam vitamina $\mathrm{D}$, uočeno je postojanje statističke razlike u distribuciji genotipova za CYP24A1 (rs2296241) polimorfizam između grupe pacijenata sa oralnim karcinomom i kontrolne grupe ( $\mathrm{p}=0.025$, Fisher test) (Tabela 9., Slika 27.). Za rs4646536 polimorfizam u CYP27B1 genu nije registrovana značajnost $u$ distribuciji genotipova između OSCC i kontrolne grupe (Tabela 9., Slika 27.).

Tabela 9. Distribucija proučavanih polimorfizama u CYP27B1 i CYP24A1 genima u OSCC i kontrolnoj grupi

\begin{tabular}{|cccccc|}
\hline \hline \multirow{2}{*}{ Gen/SNP } & Genotip & OSCC & & Kontrole & \multirow{2}{*}{$\mathbf{p}^{*}$} \\
\cline { 3 - 4 } & & $\mathbf{N}$ & $\mathbf{N}$ & \\
\hline \hline CYP27B1 & CC & 15 & & 19 & \\
rs4646536 & CT & 40 & & 46 & 0.859 \\
& TT & 55 & 57 & \\
\hline CYP24A1 & AA & 45 & & 32 & \\
rs2296241 & AG & 65 & 90 & $\mathbf{0 . 0 2 5}$ \\
\hline \hline
\end{tabular}

*Vrednosti $\mathrm{p}<0.05$ su podebljane

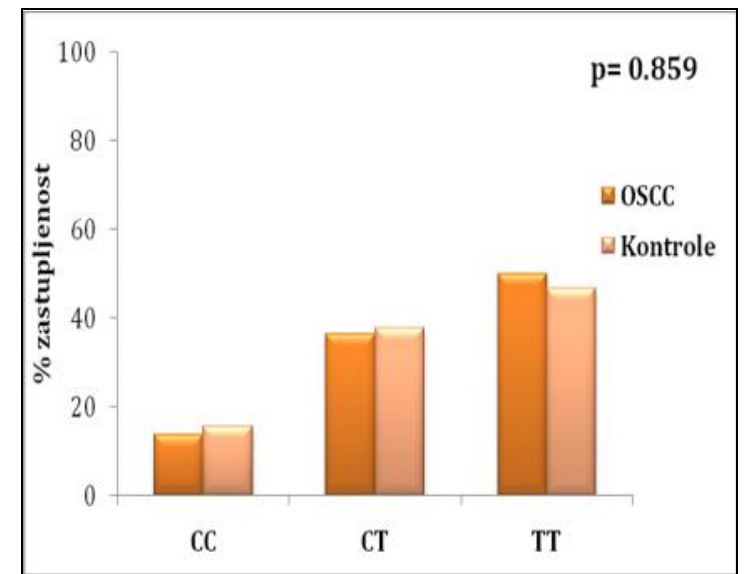

a)

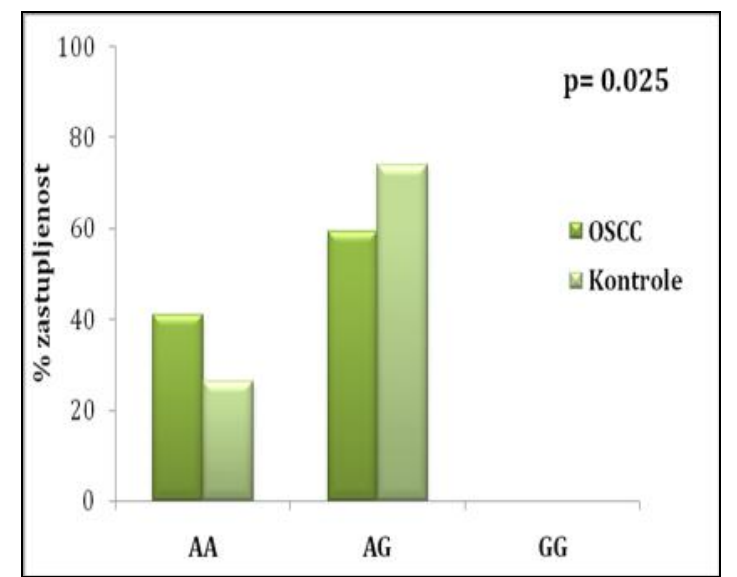

b)

Slika 27. Procentualne zastupljenosti genotipova analiziranih polimorfizama $u$ CYP27B1 i CYP24A1 genu u OSCC i kontrolnoj grupi a) rs4646536

b) $\mathrm{rs} 2296241$ 
Tabelom 10. su predstavljene učestalosti alela proučavanih polimorfizama u CYP27B1 i CYP24A1 genima. Naši rezultati pokazuju da za analizirane polimorfizme u CYP27B1 i CYP24A1 genu ne postoji razlika u zastupljenosti alela (Tabela 10.) u oba slučaja.

Tabela 10. Učestalost alela proučavanih polimorfizama CYP27B1 i CYP24A1 gena u OSCC i kontrolnoj grupi

\begin{tabular}{|c|c|c|c|c|}
\hline \multirow{2}{*}{ Gen/SNP } & \multirow{2}{*}{ Alel } & OSCC & Kontrole & \multirow{2}{*}{$\mathbf{p}$} \\
\hline & & $\mathbf{N}$ & $\mathbf{N}$ & \\
\hline \multirow{2}{*}{$\begin{array}{c}\text { CYP27B1 } \\
\text { rs4646536 }\end{array}$} & C & 70 & 83 & \multirow{2}{*}{0.615} \\
\hline & $\mathbf{T}$ & 150 & 161 & \\
\hline \multirow{3}{*}{$\begin{array}{c}\text { CYP24A1 } \\
\text { rs2296241 }\end{array}$} & A & 154 & 154 & \multirow{3}{*}{0.117} \\
\hline & & & & \\
\hline & G & 66 & 90 & \\
\hline
\end{tabular}

U slučaju polimorfizma u CYP24A1 genu, uočeno je postojanje statistički značajne razlike između pripadnika muškog pola OSCC i kontrolne grupe $(p=0.019$, Fisher test) što nije detektovano između pripadnica ženskog pola iz grupe pacijenata i kontrolne grupe. Za preostale proučavane polimorfizme u studiji, stratifikacija prema polu nije pokazala postojanje statistički značajne razlike. 


\subsection{Etiološke i kliničko patološke odlike ispitivane grupe pacijenata}

Asocijacija između analiziranih polimorfizama u VDR, CYP27B1 i CYP24A1 genima i etiološkim faktorima su predstavljeni Tabelom 11. Asocijacija sa polom je primećena za VDR TaqI ( $p=0.006, \chi^{2}$ test), BsmI ( $p=0.002, \chi^{2}$ test) i CYP27B1 rs4646536 ( $\mathrm{p}=0.014, \chi^{2}$ test $)$ polimorfizme za mutirane homozigote i heterozigotne genotipove zbirno, u poređenju sa divljim homozigotom $u$ sva tri slučaja (Tabela 11.). Statistička značajna veza između godina i analiziranih SNP-ova je zabeležena za ApaI polimorfizam ( $p=0.049, \chi^{2}$ test) kod mutiranih i heterozigotnih genotipova združeno nasuprot divljem genotipu (Tabela 11.). Pušenje je u asocijaciji sa mutiranom i heterozigotnom formom TaqI polimorfizma $\mathrm{u}$ odnosu na divlju formu ( $\mathrm{p}=0.039, \chi^{2}$ test). Takođe je uočena povezanost između CYP27B1 rs4646536 i konzumacije alkohola ( $\mathrm{p}=0.012, \chi^{2}$ test) (Tabela 11.).

Povezanost polimorfizama u VDR, CYP27B1 i CYP24A1 genima sa kliničko patološkim varijablama u proučavanoj OSCC grupi su predstavljeni Tabelom 12. Za TaqI polimorfizam je zabeležena značajna veza sa pojavom recidiva bolesti ( $p=0.008, \chi^{2}$ test). Preostale kliničko patološke varijable: OSCC stadijum, veličina tumora, nodalni status kao i histološki i nukleusni gradus nisu bili asocirni sa analiziranim polimorfizmima u ovoj studiji (Tabela 12.). 
Tabela 11. Povezanost polimorfizama u VDR, CYP27B1 i CYP24A1 genima sa etiološkim faktorima

\begin{tabular}{|c|c|c|c|c|c|c|c|c|c|}
\hline Varijable & $\mathbf{N}$ & $\begin{array}{c}\text { VDR } \\
\text { EcoRV }\end{array}$ & $\begin{array}{l}\text { VDR } \\
\text { FokI }\end{array}$ & $\begin{array}{l}\text { VDR } \\
\text { TaqI }\end{array}$ & $\begin{array}{l}\text { VDR } \\
\text { ApaI }\end{array}$ & $\begin{array}{l}\text { VDR } \\
\text { BsmI }\end{array}$ & $\begin{array}{c}\text { VDR } \\
\text { rs11574085 }\end{array}$ & $\begin{array}{c}\text { CYP27B1 } \\
\text { rs4646536 }\end{array}$ & $\begin{array}{c}\text { CYP24A1 } \\
\text { rs2296241 }\end{array}$ \\
\hline & & \multicolumn{8}{|c|}{$w t /$ heterozigot/mutirani homozigot } \\
\hline \multicolumn{10}{|l|}{ Pol } \\
\hline Muški & 81 & $26 / 45 / 10$ & $24 / 50 / 7$ & $24 / 49 / 8$ & $22 / 36 / 23$ & $22 / 59 / 0$ & $75 / 6 / 0$ & $15 / 28 / 38$ & $36 / 45 / 0$ \\
\hline \multirow[t]{2}{*}{ Ženski } & 29 & $9 / 17 / 3$ & $8 / 17 / 4$ & $17 / 9 / 3$ & 38246 & $17 / 12 / 0$ & $27 / 2 / 0$ & $12 / 17 / 0$ & $9 / 20 / 0$ \\
\hline & $\mathrm{p}^{*}$ & NSZ & NSZ & 0.006 & NSZ & 0.002 & NSZ & 0.014 & NSZ \\
\hline \multicolumn{10}{|l|}{ Godine $^{\#}$} \\
\hline$<58$ & 51 & $13 / 29 / 9$ & $16 / 31 / 4$ & $20 / 27 / 4$ & $19 / 20 / 12$ & $19 / 32 / 0$ & $46 / 5 / 0$ & $10 / 18 / 23$ & $18 / 33 / 0$ \\
\hline \multirow[t]{2}{*}{$\geq 58$} & 59 & $22 / 33 / 4$ & $16 / 36 / 7$ & $21 / 31 / 7$ & $12 / 32 / 15$ & $20 / 39 / 0$ & $56 / 3 / 0$ & $5 / 22 / 32$ & $27 / 32 / 0$ \\
\hline & $\mathrm{p}^{*}$ & NSZ & NSZ & NSZ & 0.049 & NSZ & NSZ & NSZ & NSZ \\
\hline \multicolumn{10}{|l|}{ Pušenje } \\
\hline $\mathrm{Ne} /$ bivši & 28 & $7 / 16 / 5$ & $7 / 19 / 2$ & $15 / 11 / 2$ & $7 / 14 / 7$ & $13 / 15 / 0$ & $24 / 4 / 0$ & $3 / 12 / 13$ & $10 / 18 / 0$ \\
\hline \multirow[t]{2}{*}{$\mathrm{Da}$} & 82 & $28 / 46 / 8$ & $25 / 48 / 9$ & $26 / 47 / 9$ & $24 / 38 / 20$ & $26 / 56 / 0$ & $78 / 4 / 0$ & $12 / 28 / 42$ & $35 / 47 / 0$ \\
\hline & $\mathrm{p}^{*}$ & NSZ & NSZ & 0.039 & NSZ & NSZ & NSZ & NSZ & NSZ \\
\hline \multicolumn{10}{|l|}{ Alkohol } \\
\hline $\mathrm{Ne} /$ bivši & 75 & $25 / 41 / 9$ & $20 / 47 / 8$ & $32 / 33 / 10$ & $21 / 36 / 18$ & $31 / 44 / 0$ & $68 / 7 / 0$ & $6 / 31 / 38$ & $35 / 40 / 0$ \\
\hline \multirow[t]{2}{*}{$\mathrm{Da}$} & 35 & $10 / 21 / 4$ & $12 / 20 / 3$ & $9 / 25 / 1$ & $10 / 16 / 9$ & $8 / 27 / 0$ & $34 / 1 / 0$ & $9 / 9 / 17$ & $10 / 25 / 0$ \\
\hline & $\mathrm{p}^{*}$ & NSZ & NSZ & NSZ & NSZ & NSZ & NSZ & 0.012 & NSZ \\
\hline \multicolumn{10}{|l|}{$\begin{array}{l}\text { Oralna } \\
\text { higijena }\end{array}$} \\
\hline Dobra & 54 & $13 / 31 / 10$ & $14 / 35 / 5$ & $24 / 24 / 6$ & $18 / 25 / 11$ & $23 / 31 / 0$ & $50 / 4 / 0$ & $7 / 22 / 25$ & $23 / 31 / 0$ \\
\hline \multirow[t]{2}{*}{ Loša } & 56 & $22 / 31 / 3$ & $18 / 32 / 6$ & $17 / 34 / 5$ & $13 / 27 / 16$ & $16 / 40 / 0$ & $52 / 4 / 0$ & $8 / 18 / 30$ & $22 / 34 / 0$ \\
\hline & $\mathrm{p}^{*}$ & NSZ & NSZ & NSZ & NSZ & NSZ & NSZ & NSZ & NSZ \\
\hline
\end{tabular}

*Vrednosti $\mathrm{p}<0.05$ su podebljane

$\mathrm{N}$ - ukupan broj pacijenata u datoj kategoriji

NSZ- Nije statistički značajno 
Tabela 12. Povezanost polimorfizama u VDR, CYP27B1 i CYP24A1 genima sa kliničko patološkim karakteristikama OSCC grupe

\begin{tabular}{|c|c|c|c|c|c|c|c|c|c|}
\hline Varijable & $\mathbf{N}$ & $\begin{array}{c}\text { VDR } \\
\text { EcoRV }\end{array}$ & $\begin{array}{l}\text { VDR } \\
\text { FokI }\end{array}$ & $\begin{array}{l}\text { VDR } \\
\text { TaqI }\end{array}$ & $\begin{array}{l}\text { VDR } \\
\text { ApaI }\end{array}$ & $\begin{array}{c}\text { VDR } \\
\text { BsmI }\end{array}$ & $\begin{array}{c}\text { VDR } \\
\text { rs11574085 }\end{array}$ & $\begin{array}{c}\text { CYP27B1 } \\
\text { rs4646536 }\end{array}$ & $\begin{array}{l}\text { CYP24A1 } \\
\text { rs2296241 }\end{array}$ \\
\hline & & \multicolumn{8}{|c|}{$w t /$ heterozigot/mutirani homozigot } \\
\hline \multicolumn{10}{|l|}{ Stadijum } \\
\hline II & 27 & $7 / 17 / 3$ & $8 / 16 / 3$ & $9 / 15 / 3$ & $9 / 14 / 4$ & $10 / 17 / 0$ & $27 / 0 / 0$ & $4 / 10 / 13$ & $8 / 19 / 0$ \\
\hline \multirow[t]{2}{*}{ III } & 83 & $28 / 45 / 10$ & $24 / 51 / 8$ & $32 / 43 / 8$ & $22 / 38 / 23$ & $29 / 54 / 0$ & $75 / 8 / 0$ & $11 / 30 / 42$ & $37 / 46 / 0$ \\
\hline & $\mathrm{p}^{*}$ & NSZ & NSZ & NSZ & NSZ & NSZ & NSZ & NSZ & NSZ \\
\hline \multicolumn{10}{|l|}{ Velič. tum. } \\
\hline $\mathrm{T} 1 / 2$ & 82 & $28 / 43 / 11$ & $22 / 49 / 11$ & $29 / 45 / 8$ & $25 / 40 / 17$ & $28 / 54 / 0$ & $77 / 5 / 0$ & $11 / 29 / 42$ & $37 / 45 / 0$ \\
\hline \multirow[t]{2}{*}{$\mathrm{T} 3 / 4$} & 28 & $7 / 19 / 2$ & $10 / 18 / 0$ & $12 / 13 / 3$ & $6 / 12 / 10$ & $11 / 17 / 0$ & $25 / 3 / 0$ & $4 / 11 / 13$ & $8 / 20 / 0$ \\
\hline & $\mathrm{p}^{*}$ & NSZ & NSZ & NSZ & NSZ & NSZ & NSZ & NSZ & NSZ \\
\hline \multicolumn{10}{|l|}{ Nod. status } \\
\hline No & 23 & $7 / 14 / 2$ & $6 / 14 / 3$ & $9 / 12 / 2$ & $8 / 13 / 2$ & $10 / 13 / 0$ & $23 / 0 / 0$ & $5 / 7 / 11$ & $7 / 16 / 0$ \\
\hline $\mathrm{N}+$ & 87 & $28 / 48 / 11$ & $26 / 53 / 8$ & $32 / 46 / 9$ & $23 / 39 / 25$ & $29 / 58 / 0$ & $79 / 8 / 0$ & $10 / 33 / 44$ & $38 / 49 / 0$ \\
\hline & $\mathrm{p}^{*}$ & NSZ & NSZ & NSZ & NSZ & NSZ & NSZ & NSZ & NSZ \\
\hline \multicolumn{10}{|l|}{ Recidiv } \\
\hline R0 & 49 & $17 / 26 / 6$ & $13 / 27 / 9$ & $25 / 19 / 5$ & $17 / 23 / 9$ & $22 / 27 / 0$ & $44 / 5 / 0$ & $4 / 24 / 21$ & $24 / 25 / 0$ \\
\hline $\mathrm{R}+$ & 61 & $18 / 36 / 7$ & $19 / 40 / 2$ & $16 / 39 / 6$ & $14 / 29 / 18$ & $17 / 44 / 0$ & $58 / 3 / 0$ & $11 / 16 / 34$ & $21 / 40 / 0$ \\
\hline & $\mathrm{p}^{*}$ & NSZ & NSZ & 0.008 & NSZ & NSZ & NSZ & NSZ & NSZ \\
\hline \multicolumn{10}{|l|}{ Hist.grad. } \\
\hline $\mathrm{H} 1$ & 30 & $11 / 15 / 4$ & $7 / 19 / 4$ & $11 / 14 / 5$ & $7 / 17 / 6$ & $10 / 20 / 0$ & $29 / 1 / 0$ & $4 / 12 / 14$ & $17 / 13 / 0$ \\
\hline $\mathrm{H} 2$ & 60 & $21 / 32 / 7$ & $16 / 37 / 7$ & $25 / 31 / 4$ & $20 / 25 / 15$ & $23 / 37 / 0$ & $54 / 6 / 0$ & $6 / 23 / 31$ & $20 / 40 / 0$ \\
\hline H3 & 20 & $3 / 15 / 2$ & $9 / 11 / 0$ & $5 / 13 / 2$ & $4 / 10 / 6$ & $6 / 14 / 0$ & $19 / 1 / 0$ & $5 / 5 / 10$ & $8 / 12 / 0$ \\
\hline & $\mathrm{p}^{*}$ & NSZ & NSZ & NSZ & NSZ & NSZ & NSZ & NSZ & NSZ \\
\hline \multicolumn{10}{|l|}{ Nukl. grad. } \\
\hline 1 & 19 & $8 / 7 / 4$ & $2 / 15 / 2$ & $9 / 8 / 2$ & $5 / 9 / 5$ & $7 / 12 / 0$ & $17 / 2 / 0$ & $2 / 8 / 9$ & $11 / 8 / 0$ \\
\hline 2 & 56 & $18 / 33 / 5$ & $18 / 30 / 8$ & $21 / 30 / 5$ & $17 / 27 / 12$ & $30 / 36 / 0$ & $51 / 5 / 0$ & $8 / 21 / 27$ & $22 / 34 / 0$ \\
\hline 3 & 35 & $9 / 22 / 4$ & $12 / 22 / 1$ & $11 / 20 / 4$ & $9 / 16 / 10$ & $12 / 23 / 0$ & $34 / 1 / 0$ & $5 / 11 / 19$ & $12 / 23 / 0$ \\
\hline & $\mathrm{p}^{*}$ & NSZ & NSZ & NSZ & NSZ & NSZ & NSZ & NSZ & NSZ \\
\hline
\end{tabular}

*Vrednosti $\mathrm{p}<0.05$ su podebljane

$\mathrm{N}$-ukupan broj pacijenata u datoj kategoriji

NSZ- Nije statistički značajno

Velič. tum.- Veličina tumora; Nod. status- Nodalni status; Hist. grad.- Histološki gradus; Nukl.grad.- Nukleusni gradus 
U cilju ispitivanja postojanja asocijacije između određenog genotipa i rizika za razvoj OSCC-a, računat je crude Odds Ratio logističkom regresionom analizom (Tabela 13.). Statistički značajno smanjenje rizika za razvoj OSCC je uočeno u slučaju mutiranog EE genotipa EcoRV ( $\mathrm{OR}=0.341, \mathrm{p}=0.008)$, mutiranog genotipa AA ApaI $(\mathrm{OR}=0.486, \mathrm{p}=0.040)$ polimorfizama VDR gena i heterozigotnog genotipa CYP24A1 gena $(\mathrm{OR}=0.514, \mathrm{p}=0.018) \mathrm{u}$ poređenju sa $w t$ formom u sva tri slučaja (Tabela 13.). Heterozigotni genotip VDR BsmI polimorfizma je značajno asociran sa povišenim rizikom za razvoj oralnog karcinoma (OR=1.790, p=0.032), ali i heterozigotni i mutirani genotip zajedno $\mathrm{u}$ odnosu na $w t$ genotip $(\mathrm{OR}=1.705$, $\mathrm{p}=0.048)$ (Tabela 13.).

U tabeli 14. je prikazan crude Odds Ratio za ispitivane alele analiziranih polimorfizama i rizika za razvoj OSCC. Mutirani alel E EcoRV polimorfizma je značajno asociran sa smanjenim rizikom za razvoj OSCC-a u poređenju sa wt e alelom (OR=0.645, $\mathrm{p}=0.019)$. U slučaju polimorfizma ApaI, mutirani alel A je statistički značajno povezan sa smanjenjem rizika za razvoj oralnog karcinoma u poređenju sa $w t$ alelom a $(\mathrm{OR}=0.645, \mathrm{p}=0.019)$. Aleli drugih ispitivanih polimorfizama nisu bili u vezi sa povećanim niti smanjenim rizikom za razvoj OSCC.

Adjusted Odds Ratio, kombinovan sa podacima o konzumiranju alkohola, pušenju, godinama i polu je pokazao statistički značajno smanjenje rizika za razvoj oralnog karcinoma kod heterozigota AG polimorfizma rs2296241 CYP24A1 gena, u odnosu na wt AA genotip (OR=0.281, $\mathrm{p}=0.000)$ (Tabela 15.). U slučaju EE mutiranog genotipa EcoRV polimorfizma u poređenju sa $w t$ ee genotipom nije dostignuta statistička značajnost, ali se zapaža trend smanjivanja rizika za razvoj oralnog karcinoma (OR=0.388, $\mathrm{p}=0.063$ ) (Tabela 15.). Ni jedan od preostalih genotipova proučavanih polimorfizama u VDR i CYP27B1 genu nije bio značajno povezan sa rizikom za nastanak OSCC-a (Tabela 15.). 
Tabela 13. VDR, CYP27B1 i CYP24A1 polimorfizmi i rizik za nastanak oralnog karcinoma-crude Odds Ratio

\begin{tabular}{|c|c|c|c|c|c|c|c|}
\hline \multirow{2}{*}{ Gen/SNP } & \multirow{2}{*}{ Genotip } & \multicolumn{2}{|c|}{ OSCC } & \multicolumn{2}{|c|}{ Kontrole } & \multirow{2}{*}{ Crude OR (95\% CI) } & \multirow{2}{*}{$\mathbf{p}^{*}$} \\
\hline & & $\mathbf{N}$ & $\%$ & $\mathbf{N}$ & $\%$ & & \\
\hline \multirow{4}{*}{$\begin{array}{l}\text { VDR } \\
\text { EcoRV }\end{array}$} & ee & 35 & 31.8 & 34 & 27.9 & 1 & Ref. \\
\hline & Ee & 62 & 56.4 & 51 & 41.8 & $1.181(0.648-2.152)$ & 0.587 \\
\hline & $\mathrm{EE}$ & 13 & 11.8 & 37 & 30.3 & $0.341(0.155-0.751)$ & 0.008 \\
\hline & $\mathrm{Ee}+\mathrm{EE} \#$ & 75 & 68.2 & 88 & 72.1 & $0.828(0.471-1.455)$ & 0.511 \\
\hline \multirow{4}{*}{$\begin{array}{l}\text { VDR } \\
\text { FokI }\end{array}$} & $\mathrm{ff}$ & 32 & 29.1 & 46 & 37.7 & 1 & Ref. \\
\hline & $\mathrm{Ff}$ & 67 & 60.9 & 62 & 50.8 & $1.553(0.880-2.742)$ & 0.129 \\
\hline & $\mathrm{FF}$ & 11 & 10 & 14 & 11.5 & $1.129(0.455-2.805)$ & 0.793 \\
\hline & $\mathrm{Ff}+\mathrm{FF} \#$ & 78 & 70.9 & 76 & 62.3 & $1.475(0.851-2.559)$ & 0.166 \\
\hline \multirow{4}{*}{$\begin{array}{l}\text { VDR } \\
\text { TaqI }\end{array}$} & $\mathrm{TT}$ & 41 & 37.3 & 59 & 48.4 & 1 & Ref. \\
\hline & $\mathrm{Tt}$ & 58 & 52.7 & 48 & 39.3 & $1.739(1.001-3.021)$ & 0.050 \\
\hline & $\mathrm{tt}$ & 11 & 10 & 15 & 12.3 & $1.055(0.440-2.529)$ & 0.904 \\
\hline & $\mathrm{Tt}+\mathrm{tt}^{\#}$ & 69 & 62.7 & 63 & 51.6 & $1.576(0.932-2.664)$ & 0.089 \\
\hline \multirow{4}{*}{$\begin{array}{l}\text { VDR } \\
\text { ApaI }\end{array}$} & aa & 31 & 28.2 & 29 & 23.8 & 1 & Ref. \\
\hline & $\mathrm{Aa}$ & 52 & 47.3 & 41 & 33.6 & $1.186(0.619-2.275)$ & 0.607 \\
\hline & $\mathrm{AA}$ & 27 & 24.5 & 52 & 42.6 & $0.486(0.244-0.966)$ & 0.040 \\
\hline & $\mathrm{Aa}+\mathrm{AA}^{\#}$ & 79 & 71.8 & 93 & 76.2 & $0.795(0.441-1.431)$ & 0.444 \\
\hline \multirow{4}{*}{$\begin{array}{l}\text { VDR } \\
\text { BsmI }\end{array}$} & $\mathrm{bb}$ & 39 & 35.5 & 59 & 48.4 & 1 & Ref. \\
\hline & $\mathrm{Bb}$ & 71 & 64.5 & 60 & 49.2 & $1.790(1.053-3.044)$ & 0.032 \\
\hline & BB & 0 & 0 & 3 & 2.4 & NR & NR \\
\hline & $\mathrm{Bb}+\mathrm{BB} \#$ & 71 & 64.5 & 63 & 51.6 & $1.705(1.006-2.891)$ & 0.048 \\
\hline \multirow{4}{*}{$\begin{array}{c}\text { VDR } \\
\text { rs11574085 }\end{array}$} & $\mathrm{AA}$ & 102 & 92.7 & 110 & 90.2 & 1 & Ref. \\
\hline & AT & 8 & 7.3 & 12 & 9.8 & $0.719(0.282-1.830)$ & 0.489 \\
\hline & TT & / & / & / & / & NR & NR \\
\hline & $\mathrm{AT}+\mathrm{TT} \#$ & I & 1 & I & I & NR & NR \\
\hline \multirow{4}{*}{$\begin{array}{c}\text { CYP27B1 } \\
\text { rs4646536 }\end{array}$} & CC & 15 & 13.6 & 19 & 15.6 & 1 & Ref. \\
\hline & CT & 40 & 36.4 & 46 & 37.7 & $1.101(0.496-2.448)$ & 0.813 \\
\hline & TT & 55 & 50 & 57 & 46.7 & $1.222(0.565-2.644)$ & 0.61 \\
\hline & $\mathrm{CT}+\mathrm{TT} \#$ & 95 & 86.4 & 103 & 84.4 & $1.168(0.562-2.429)$ & 0.677 \\
\hline \multirow{4}{*}{$\begin{array}{l}\text { CYP24A1 } \\
\text { rs2296241 }\end{array}$} & $\mathrm{AA}$ & 45 & 40.9 & 32 & 26.2 & 1 & Ref. \\
\hline & AG & 65 & 59.1 & 90 & 73.8 & $0.514(0.295-0.894)$ & 0.018 \\
\hline & GG & / & / & / & / & NR & NR \\
\hline & $\mathrm{AG}+\mathrm{GG}^{\#}$ & l & l & l & l & NR & NR \\
\hline
\end{tabular}

*Vrednosti $\mathrm{p}<0.05$ su podebljane

\#Heterozigot i mutirani homozigot združeni vs. wt genotip

Ref.- Referentna vrednost; NR- Nije računato 
Tabela 14. Aleli analiziranih polimorfizama u VDR, CYP27B1 i CYP24A1 genima i rizik za nastanak oralnog karcinoma- crude Odds Ratio

\begin{tabular}{|c|c|c|c|c|c|c|c|}
\hline \multirow{2}{*}{ Gen/SNP } & \multirow{2}{*}{ Alel } & \multicolumn{2}{|c|}{ OSCC } & \multicolumn{2}{|c|}{ Kontrole } & \multirow{2}{*}{ Crude OR (95\% CI) } & \multirow{2}{*}{$\mathbf{p}^{*}$} \\
\hline & & $\mathbf{N}$ & $\%$ & $\mathbf{N}$ & $\%$ & & \\
\hline VDR & $\mathbf{e}$ & 132 & 60 & 120 & 49 & 1 & Ref. \\
\hline EcoRV & $\mathbf{E}$ & 88 & 40 & 124 & 51 & $0.645(0.446-0.932)$ & 0.019 \\
\hline VDR & f & 132 & 60 & 154 & 63 & 1 & Ref. \\
\hline FokI & $\mathbf{F}$ & 88 & 40 & 90 & 37 & $1.141(0.784-1.659)$ & 0.493 \\
\hline VDR & $\mathbf{T}$ & 141 & 64 & 166 & 68 & 1 & Ref. \\
\hline TaqI & $\mathbf{t}$ & 79 & 36 & 78 & 32 & $1.192(0.811-1.752)$ & 0.371 \\
\hline VDR & $\mathbf{a}$ & 114 & 52 & 100 & 41 & 1 & Ref. \\
\hline ApaI & A & 106 & 48 & 144 & 59 & $0.645(0.447-0.932)$ & 0.019 \\
\hline VDR & b & 150 & 68 & 178 & 73 & 1 & Ref. \\
\hline BsmI & B & 70 & 32 & 66 & 27 & $1.258(0.843-1.878)$ & 0.259 \\
\hline VDR & A & 211 & 96 & 232 & 95 & 1 & Ref. \\
\hline rs11574085 & $\mathbf{T}$ & 9 & 4 & 12 & 5 & $0.825(0.341-1.996)$ & 0.671 \\
\hline CYP27B1 & C & 70 & 32 & 83 & 34 & 1 & Ref. \\
\hline rs4646536 & $\mathbf{T}$ & 150 & 68 & 161 & 66 & $1.104(0.749-1.628)$ & 0.617 \\
\hline CYP24A1 & A & 154 & 70 & 154 & 63 & 1 & Ref. \\
\hline rs2296241 & G & 66 & 30 & 90 & 37 & $0.733(0.497-1.081)$ & 0.116 \\
\hline
\end{tabular}

*Vrednosti $\mathrm{p}<0.05$ su podebljane

Ref.- Referentna vrednost 
Tabela 15. VDR, CYP27B1 i CYP24A1 polimorfizmi i rizik za nastanak oralnog karcinoma-adjusted Odds Ratio

\begin{tabular}{|c|c|c|c|c|c|c|c|}
\hline \multirow{2}{*}{ Gen/SNP } & \multirow{2}{*}{ Genotip } & \multicolumn{2}{|c|}{ osCC } & \multicolumn{2}{|c|}{ Kontrole } & \multirow{2}{*}{ Adjusted OR'(95\% CI) } & \multirow{2}{*}{$\mathbf{p}^{*}$} \\
\hline & & $\mathrm{N}$ & $\%$ & $\mathbf{N}$ & $\%$ & & \\
\hline \multirow{4}{*}{$\begin{array}{l}\text { VDR } \\
\text { EcoRV }\end{array}$} & ee & 35 & 31.8 & 34 & 27.9 & 1 & Ref. \\
\hline & $\mathrm{Ee}$ & 62 & 56.4 & 51 & 41.8 & $1.083(0.517-2.270)$ & 0.832 \\
\hline & $\mathrm{EE}$ & 13 & 11.8 & 37 & 30.3 & $0.388(0.143-1.054)$ & 0.063 \\
\hline & $\mathrm{Ee}+\mathrm{EE}^{\#}$ & 75 & 68.2 & 88 & 72.1 & $0.789(0.391-1.592)$ & 0.508 \\
\hline \multirow{4}{*}{$\begin{array}{l}\text { VDR } \\
\text { FokI }\end{array}$} & Ff & 32 & 29.1 & 46 & 37.7 & 1 & Ref. \\
\hline & $\mathrm{Ff}$ & 67 & 60.9 & 62 & 50.8 & $1.841(0.906-3.739)$ & 0.091 \\
\hline & $\mathrm{FF}$ & 11 & 10 & 14 & 11.5 & $1.571(0.495-4.982)$ & 0.443 \\
\hline & $\mathrm{Ff}+\mathrm{FF} \#$ & 78 & 70.9 & 76 & 62.3 & $1.832(0.912-3.679)$ & 0.089 \\
\hline \multirow{4}{*}{$\begin{array}{l}\text { VDR } \\
\text { TaqI }\end{array}$} & TT & 41 & 37.3 & 59 & 48.4 & 1 & Ref. \\
\hline & $\mathrm{Tt}$ & 58 & 52.7 & 48 & 39.3 & $1.749(0.868-3.524)$ & 0.118 \\
\hline & $\mathrm{tt}$ & 11 & 10 & 15 & 12.3 & $1.689(0.616-4.633)$ & 0.309 \\
\hline & $\mathrm{Tt}+\mathrm{tt}^{\#}$ & 69 & 62.7 & 63 & 51.6 & $1.720(0.891-3.322)$ & 0.106 \\
\hline \multirow{4}{*}{$\begin{array}{l}\text { VDR } \\
\text { ApaI }\end{array}$} & aa & 31 & 28.2 & 29 & 23.8 & 1 & Ref. \\
\hline & $\mathrm{Aa}$ & 52 & 47.3 & 41 & 33.6 & $1.368(0.621-3.014)$ & 0.437 \\
\hline & $\mathrm{AA}$ & 27 & 24.5 & 52 & 42.6 & $0.643(0.278-1.486)$ & 0.302 \\
\hline & $\mathrm{Aa}+\mathrm{AA}^{\#}$ & 79 & 71.8 & 93 & 76.2 & $1.041(0.502-2.158)$ & 0.914 \\
\hline \multirow{4}{*}{$\begin{array}{l}\text { VDR } \\
\text { BsmI }\end{array}$} & $\mathrm{bb}$ & 39 & 35.5 & 59 & 48.4 & 1 & Ref. \\
\hline & $\mathrm{Bb}$ & 71 & 64.5 & 60 & 49.2 & $1.725(0.895-3.323)$ & 0.103 \\
\hline & BB & 0 & 0 & 3 & 2.4 & $\mathrm{NR}$ & $\mathrm{NR}$ \\
\hline & $\mathrm{Bb}+\mathrm{BB} \#$ & 71 & 64.5 & 63 & 51.6 & $1.663(0.864-3.202)$ & 0.128 \\
\hline \multirow{4}{*}{$\begin{array}{c}\text { VDR } \\
\text { rs11574085 }\end{array}$} & $\mathrm{AA}$ & 102 & 92.7 & 110 & 90.2 & 1 & Ref. \\
\hline & AT & 8 & 7.3 & 12 & 9.8 & $0.697(0.237-2.054)$ & 0.513 \\
\hline & TT & / & / & / & / & NR & $\mathrm{NR}$ \\
\hline & $\mathrm{AT}+\mathrm{TT} \#$ & I & 1 & I & I & NR & NR \\
\hline \multirow{4}{*}{$\begin{array}{l}\text { CYP27B1 } \\
\text { rs4646536 }\end{array}$} & $\mathrm{CC}$ & 15 & 13.6 & 19 & 15.6 & 1 & Ref. \\
\hline & CT & 40 & 36.4 & 46 & 37.7 & $1.612(0.535-4.857)$ & 0.396 \\
\hline & TT & 55 & 50 & 57 & 46.7 & $1.317(0.430-4.037)$ & 0.630 \\
\hline & $\mathrm{CT}+\mathrm{TT} \#$ & 95 & 86.4 & 103 & 84.4 & $1.426(0.499-4.074)$ & 0.507 \\
\hline \multirow{4}{*}{$\begin{array}{l}\text { CYP24A1 } \\
\text { rs2296241 }\end{array}$} & $\mathrm{AA}$ & 45 & 40.9 & 32 & 26.2 & 1 & Ref. \\
\hline & $\mathrm{AG}$ & 65 & 59.1 & 90 & 73.8 & $0.281(0.139-0.568)$ & 0.000 \\
\hline & GG & / & / & / & / & $\mathrm{NR}$ & NR \\
\hline & $\mathrm{AG}+\mathrm{GG}^{\#}$ & 1 & 1 & 1 & 1 & NR & NR \\
\hline
\end{tabular}

*Vrednosti $\mathrm{p}<0.05$ su podebljane; a adjusted Odds Ratio za godine, pol, alkohol i pušenje

\# Heterozigot i mutirani homozigot združeno vs. wt genotip

NR- Nije računato; Ref-Referentna vrednost 


\subsection{Analiza haplotipova}

Koeficijent neravnoteže vezanosti je računat za sve VDR proučavane SNP-ove međusobno pomoću programa Haploview 4.2. Nivo LD-a između svih parova analiziranih polimorfizama su izražene preko parametra D' i predstavljene procentualno (prikazane u kvadratićima), za celokupnu studijsku grupu, kao i kontrolnu i OSCC grupu (Slike 28., 29., 30., redom). Primenom matematičkih algoritama i EM modela, na kojima se zasniva program Haploview, za datu analiziranu grupu se procenjuje postojanje potencijalnih haplotipova i njihova učestalost.

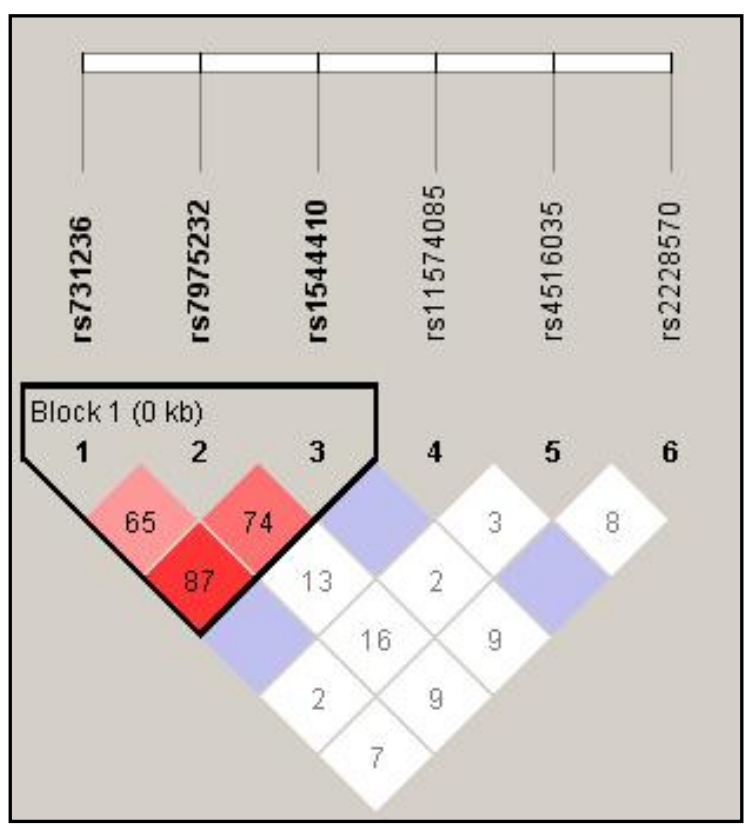

Slika 28. Neravnoteža vezanosti i haplotipski blok u celokupnoj studijskoj grupi

Za definiciju haplotipskog bloka je korišćena opcija solid spine block definition. Identifikovan je jedan haplotipski blok u celokupnoj studijskoj grupi, OSCC i kontrolnoj grupi i BsmI (rs1544410), ApaI (rs7975232) i TaqI (rs731236) polimorfizmi VDR gena su se nalazili u neravnoteži vezanosti (Slike 28., 29., 30.). Može se zapaziti da su TaqI i BsmI polimorfizmi međusobno jače vezani $\left(D^{\prime}=0.87\right)$ nego TaqI i ApaI ( $\left.D^{\prime}=0.65\right)$ odnosno BsmI i ApaI ( $\left.D^{\prime}=0.74\right)$ (Slika 28.). 


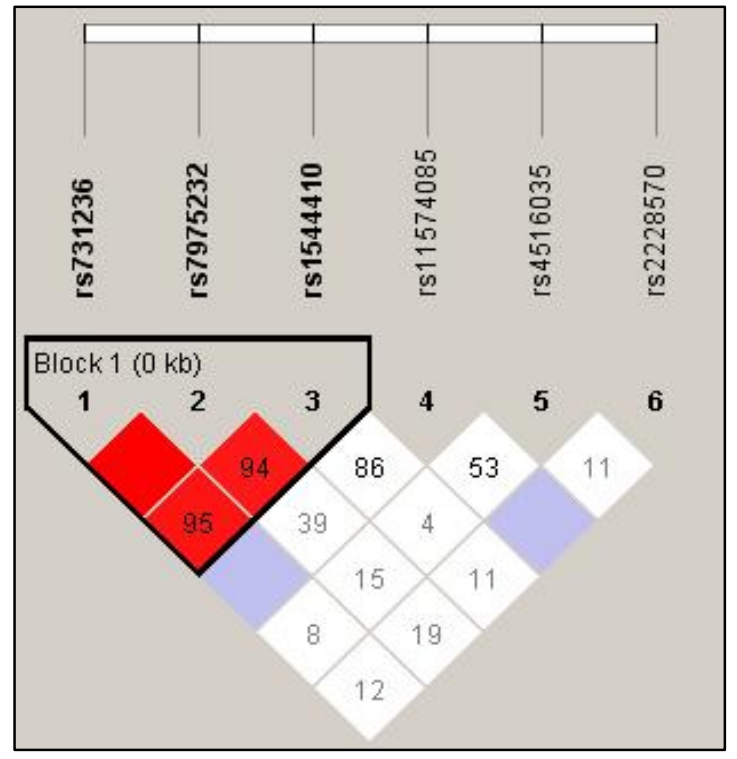

Slika 29. Neravnoteža vezanosti

i haplotipski blok u kontrolnoj grupi

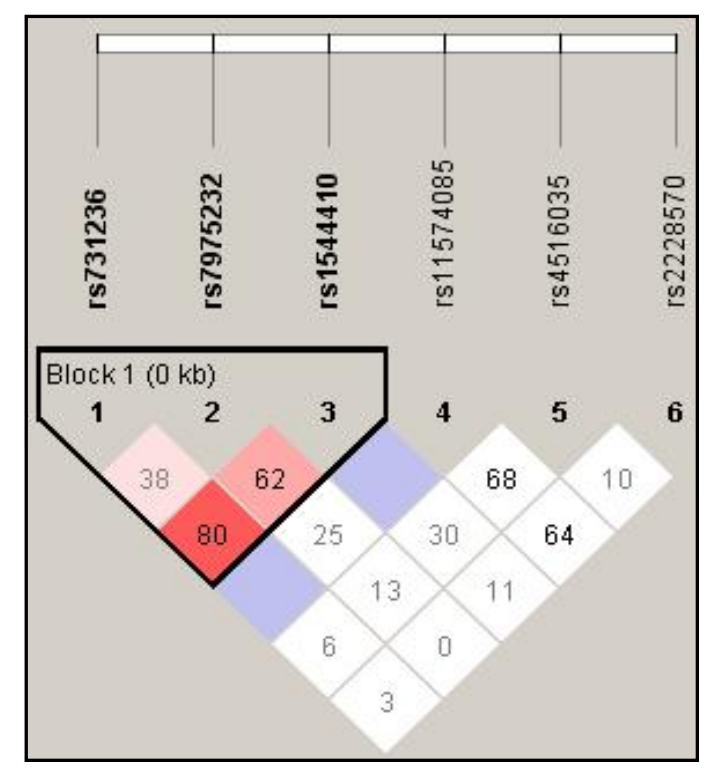

Slika 30. Neravnoteža vezanosti i haplotipski blok u OSCC grupi

Izuzetno visok nivo vezanosti između tri polimorfizma u haplotipskom bloku je zabeležen u kontrolnoj grupi (D'>0.90) (Slika 29.). Haplotipski blok unutar OSCC grupe pokazuje isti obrazac vezanosti kao i u celokupnoj studijskoj grupi, gde su TaqI i BsmI bili u jačem LD-u $\left(D^{\prime}=0.80\right)$ u odnosu na svaki od ova dva polimorfizma pojedinačno sa ApaI polimorfizmom $\left(D^{\prime}=0.38, D^{\prime}=0.62\right.$, redom) (Slika 30.).

Distribucija analiziranih VDR haplotipova unutar OSCC i kontrolne grupe je prikazana Slikom 31. Kao što se može uočiti, najčešći haplotip u grupi pacijenata i kontrolnoj grupi je bio baT (40\%) (Slika 31.,a). Haplotip BaT je bio najmanje zastupljen u grupi pacijenata (1.4\%), pri čemu nije detektovan u kontrolnoj grupi. Pored ovog, u kontrolnoj grupi nisu uočeni haplotipovi bat, Bat i BAT koji su detektovani u grupi pacijenata sa oralnim karcinomom (Slika 31.,b). 

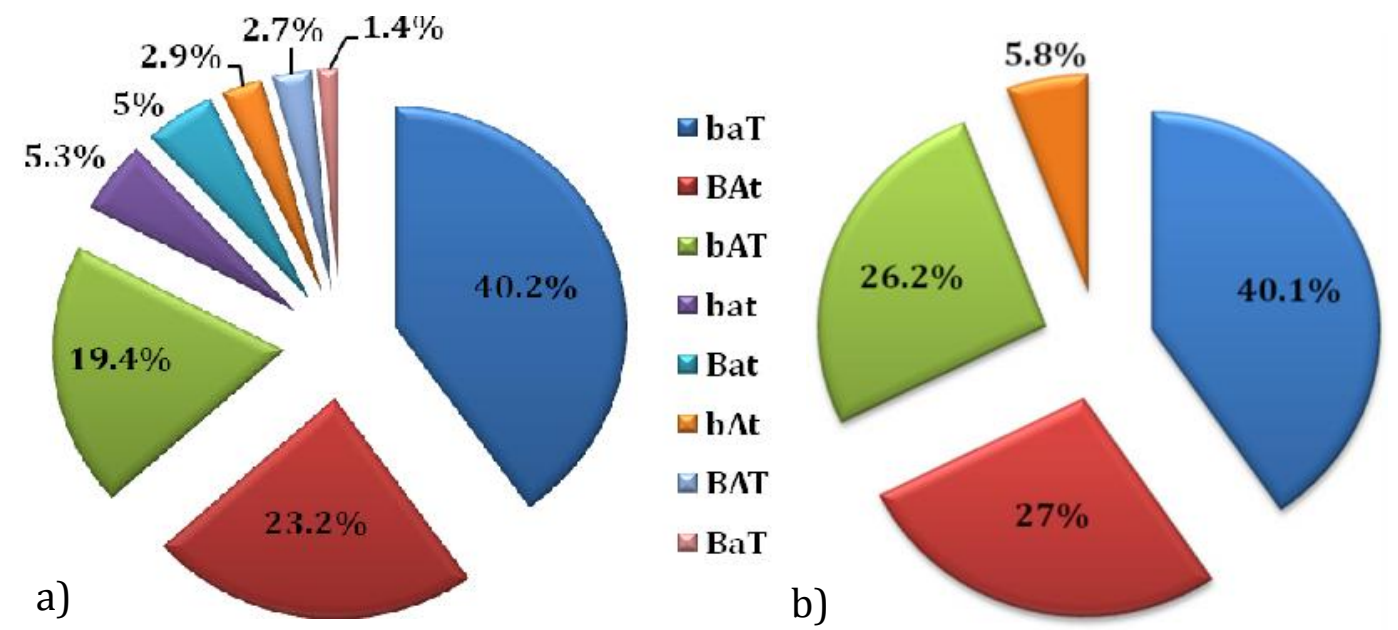

Slika 31. Procentualne zastupljenosti identifikovanih haplotipova u OSCC i kontrolnoj grupi a) OSCC b) kontrole

Analizirano je postojanje veze identifikovanih haplotipova sa rizikom za nastanak oralnog karcinoma (Tabela 16.). Za referentnu vrednost je uzet baT haplotip koji je bio najučestaliji u obe grupe. Logistička regresiona analiza je pokazala da BsmI-ApaI-TaqI tri-lokusni haplotip nije bio u statistički značajnoj asocijaciji sa rizikom za razvoj oralnog karcinoma (Tabela 16.).

Tabela 16. Asocijacija haplotipova i rizika za nastanak oralnog karcinoma

\begin{tabular}{|c|c|c|c|c|c|c|}
\hline \multirow{2}{*}{ Haplotip } & \multicolumn{2}{|c|}{ OSCC } & \multicolumn{2}{|c|}{ Kontrole } & \multirow{2}{*}{ Odds Ratio (95\% CI) } & \multirow{2}{*}{$\mathbf{p}$} \\
\hline & $2 \mathrm{~N}=220$ & $\%$ & $2 \mathrm{~N}=244$ & $\%$ & & \\
\hline baT & 88 & 40.2 & 98 & 40.1 & 1.000 & Ref. \\
\hline BAt & 51 & 23.2 & 66 & 27 & $0.861(0.540-1.370)$ & 0.527 \\
\hline bAT & 43 & 19.4 & 64 & 26.2 & $0.748(0.462-1.211)$ & 0.238 \\
\hline bat & 12 & 5.3 & / & / & NR & NR \\
\hline Bat & 11 & 5 & / & / & NR & NR \\
\hline bAt & 6 & 2.9 & 14 & 5.8 & $0.477(0.176-1.296)$ & 0.140 \\
\hline BAT & 6 & 2.7 & / & / & NR & NR \\
\hline BaT & 3 & 1.4 & / & / & NR & NR \\
\hline
\end{tabular}

Ref.- Referentna vrednost

NR- Nije računato 


\subsection{Analiza ukupnog preživljavanja}

Period praćenja pacijenata je bio od 28-100 meseci, sa medijanom preživaljavanja od 35 meseci.

Analizom Kaplan-Meier kriva preživljavanja, uočava se značajno smanjenje ukupnog preživaljavanja kod pacijenata u uznapredovalom stadijumu bolesti $\mathrm{u}$ odnosu na raniji stadijum (III vs. II, p=0.007, log-rank test) (Slika 32., a). Značajno smanjenje ukupnog preživljavanja je zabeleženo i kod pacijenata sa limfnim metastazama ( $\mathrm{N}+$ vs. N0, $\mathrm{p}=0.007$, log-rank test) (Slika 32., b), većim tumorima (T3/4 vs. T1/2, p=0.001, log-rank test) (Slika 32., c) kao i pojavom recidiva bolesti (R+ vs. R0, p=0.000, log-rank test) (Slika 32., d)

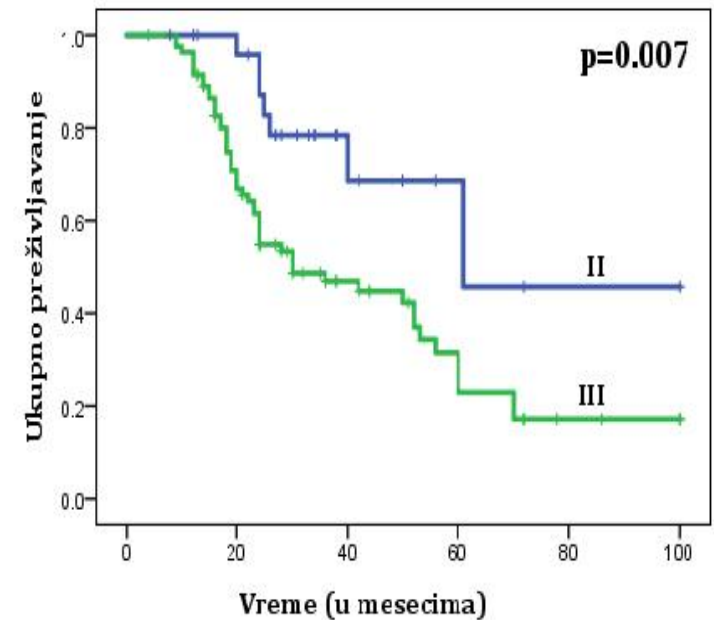

a)

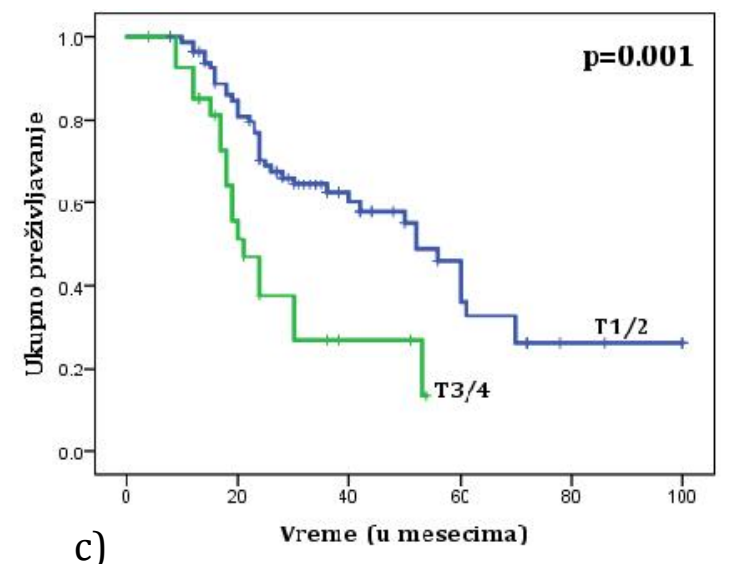

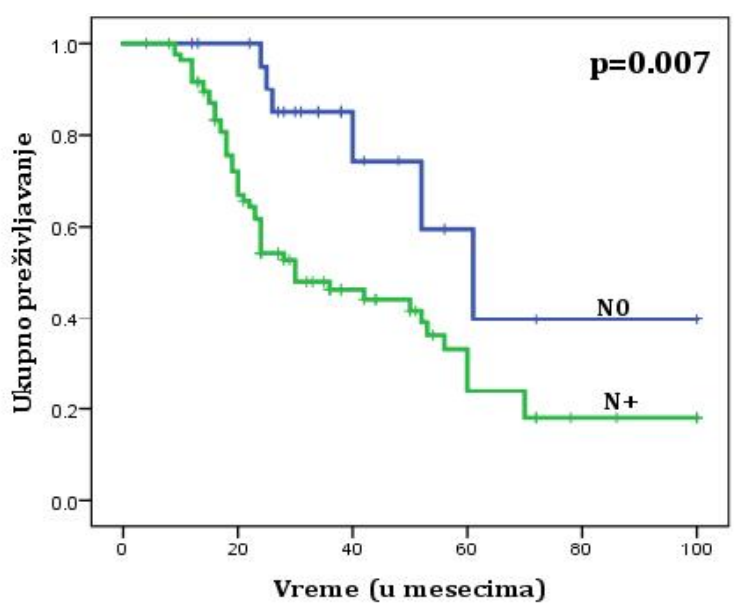

b)

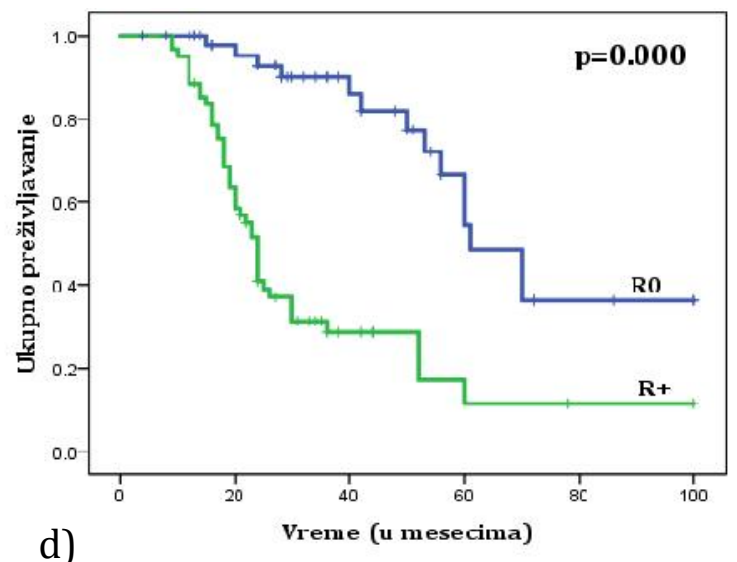

Slika 32. Kaplan-Meier krive preživljavanja a) stadijum bolesti b) nodalni status c) veličina tumora d) recidiv 
VDR FokI polimorfizam je bio $u$ asocijaciji sa smanjenim ukupnim preživljavanjem ( $\mathrm{p}=0.042$, log-rank test) (Grafik 33., a). Divlji ff genotip je asociran sa lošijim preživljavanjem ( $\mathrm{p}=0.012$, log-rank test) $\mathrm{u}$ poređenju sa heterozigotima Ff i mutiranim FF genotipovima zajedno (Grafik 33., b). Stratifikovana analiza prema postojanju limfnih metastaza je pokazala da je $w t$ ff genotip asociran sa lošijim preživljavanjem u obe grupe sa i bez limfnih metastaza $(p=0,025, p=0.040$, redom, log-rank test) (Slika 33., c, d). Pored toga, wt ff genotip je imao lošiju prognozu preživljavanja u grupi pacijenata sa III stadijumom bolesti $(\mathrm{p}=0.026)$, za razliku od II stadijuma ( $\mathrm{p}=0.079)$ gde nije postignuta statistička značajnost, ali postoji izvesna tendencija (Slika 33., e, f). Stratifikacionom analizom prema recidivu, uočeno je lošije preživaljavanje wt FokI genotipa $\mathrm{u}$ odnosu na heterozigotne i mutirane forme zajedno u podgrupi sa recidivom bolesti (R+ vs. R0, $\mathrm{p}=0.036$, log-rank test) (krive nisu prikazane).

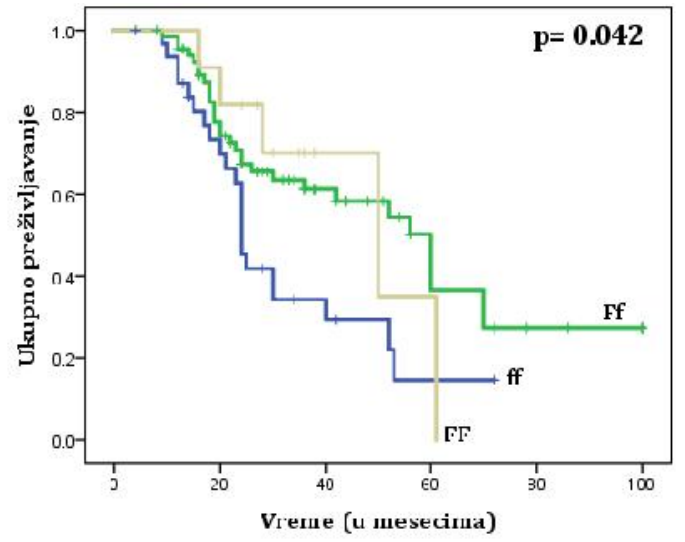

a)

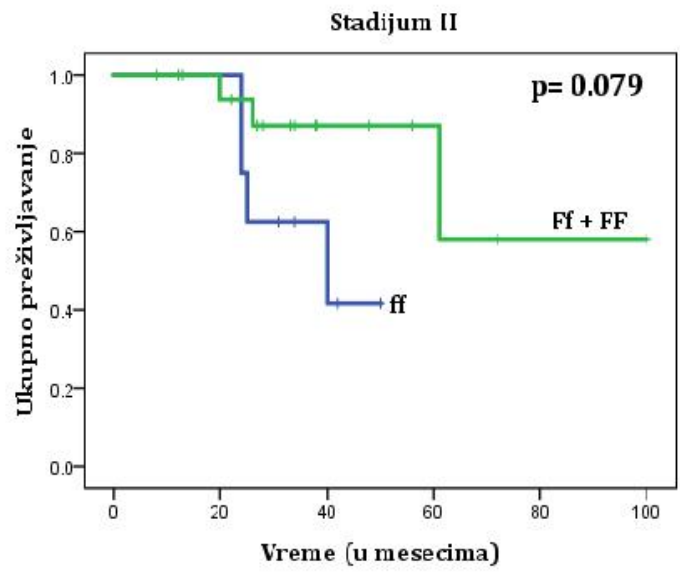

c)

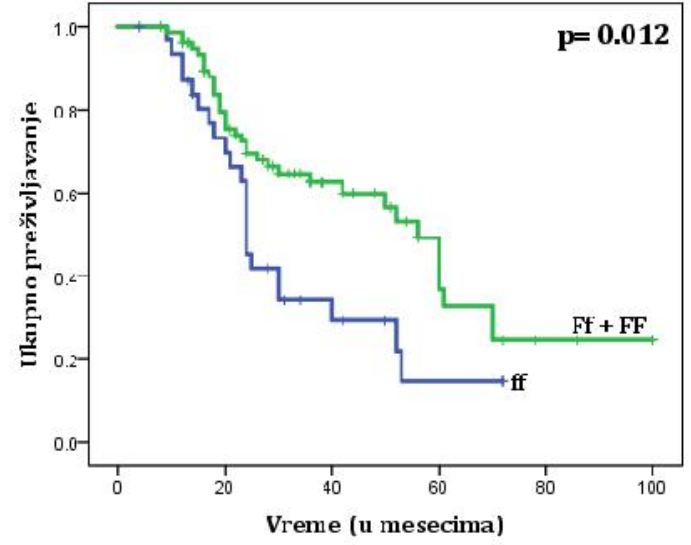

b)

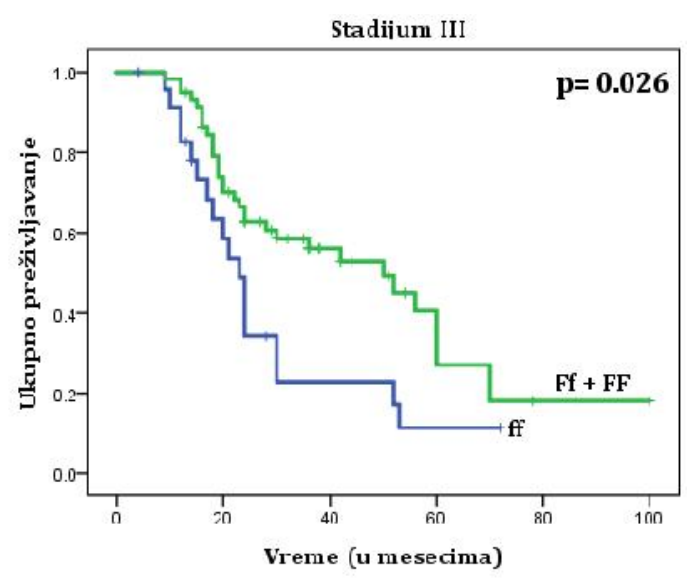

d) 


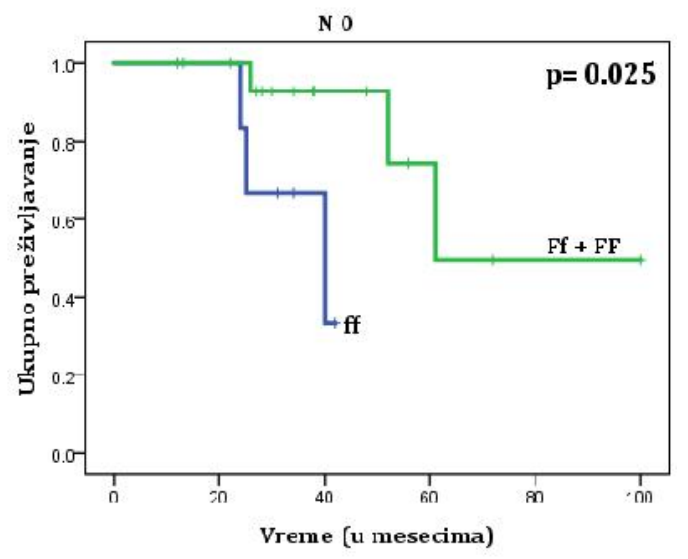

e)

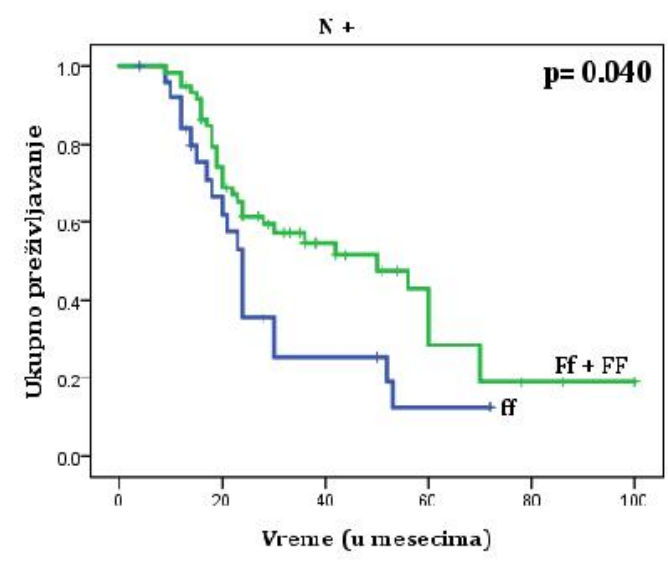

f)

Slika 33. Kaplan-Meier krive preživljavanja: a) FokI polimorfizam b) Ff +FF vs. $w t$ ff c) FokI kod pacijenata sa II stadijumom bolesti d) FokI kod pacijenata sa III stadijumom bolesti e) FokI kod pacijenata sa negativnim nodalnim statusom (N0) f) FokI kod pacijenata sa pozitivnim nodalnim statusom $(\mathrm{N}+)$

U slučaju polimorfizma rs2296241 u CYP24A1 genu, nije uočena veza sa ukupnim preživljavanjem ( $\mathrm{p}=0.108$, log-rank test) (Slika 34., a). Međutim, stratifikacija prema stadijumu bolesti je pokazala da heterozigotni genotip AG ima statistički lošije preživljavanje u odnosu na $w t \mathrm{u}$ uznapredovalom, III stadijumu bolesti ( $\mathrm{p}=0.021$, log-rank test), dok takva veza nije uočena u slučaju II stadijuma ( $p=0.989$, log-rank test) (Slika 33., b, c). Pored toga, heterozigoti su imali lošije preživljavanje u grupi pacijenata sa limfnim metastazama ( $p=0.016$, log-rank test), što nije bio slučaj u grupi pacijenata bez limfnih metastaza ( $\mathrm{p}=0.553$, log-rank test) (Slika 33., d, e). Stratifikaciona analiza prema veličini tumora i pojavom recidiva nije otkrila postojanje statistički značajnih razlika u preživljavanju između nosioca različitih genotipova (krive preživljavanja nisu predstavljene). 


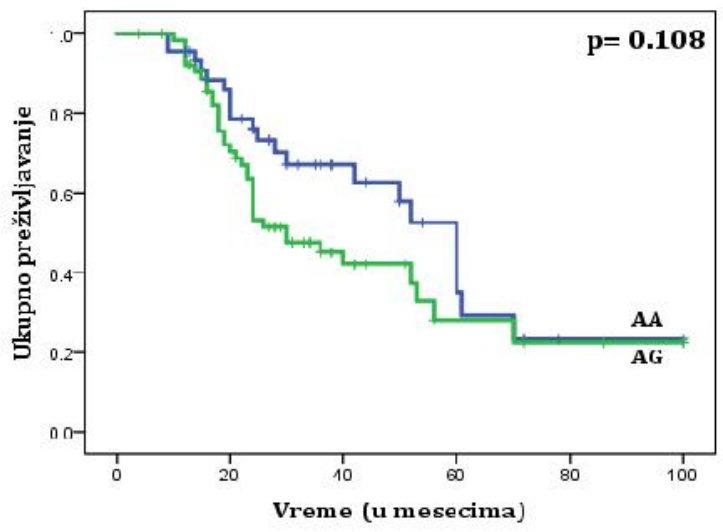

a)
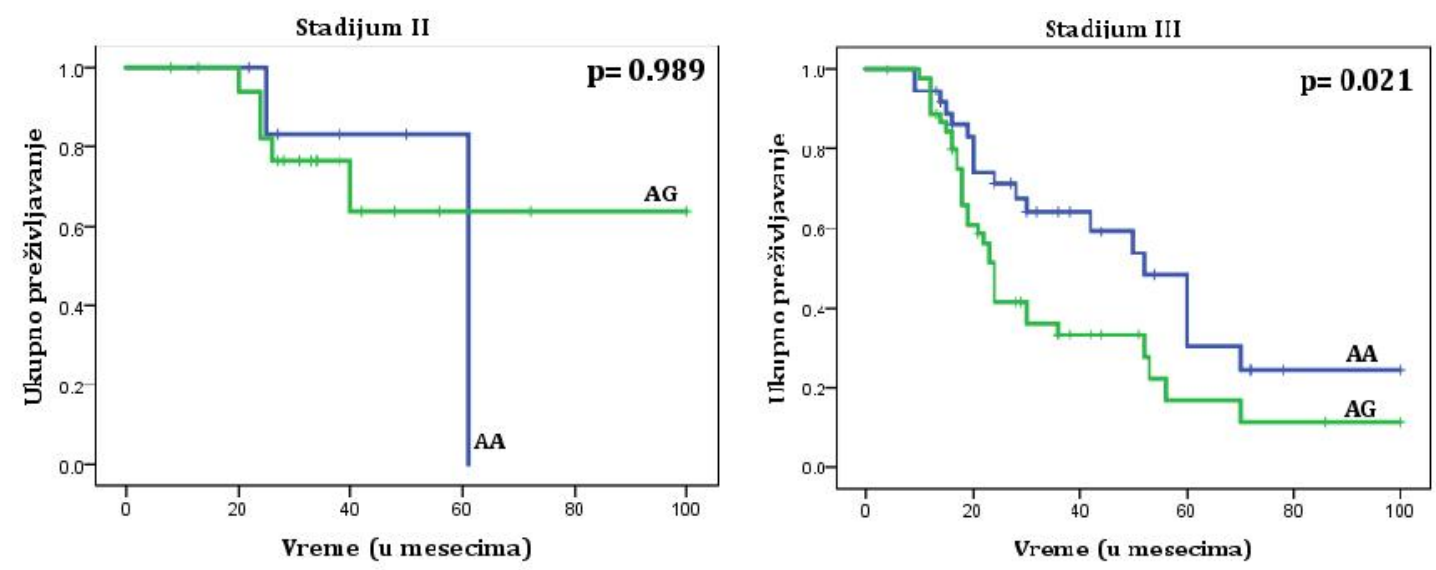

b)

c)

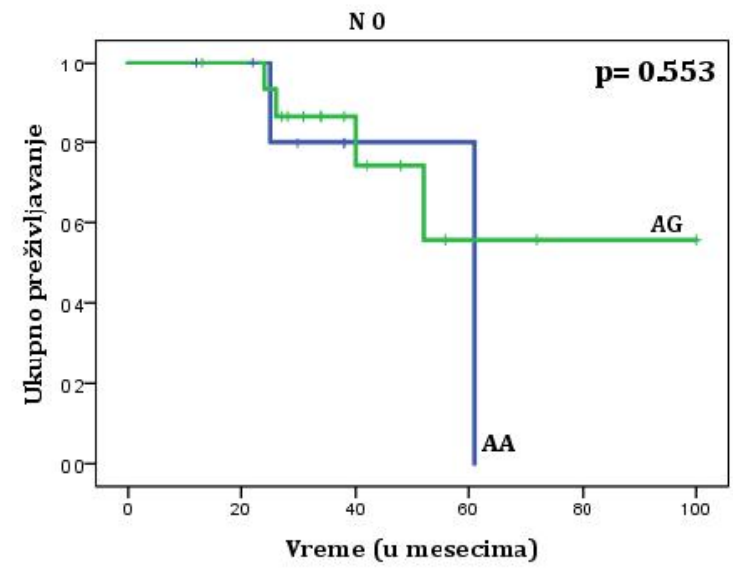

d)

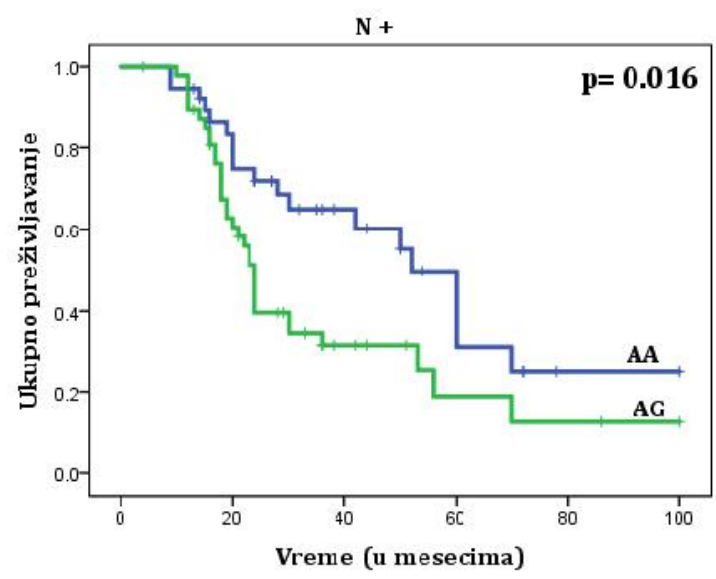

e)

Slika 34. Kaplan-Meier krive preživljavanja a) CYP24A1 (rs2296241) b) CYP24A1 kod pacijenata sa II stadijumom bolesti c) CYP24A1 kod pacijenata sa III stadijumom bolesti d) CYP24A1 kod pacijenata sa negativnim nodalnim statusom e) CYP24A1 kod pacijenata sa pozitivnim nodalnim statusom 
Preostali proučavani polimorfizmi u VDR genu kao i CYP27B1 genu nisu bili povezani sa ukupnim preživljavanjem (Slika 35.).

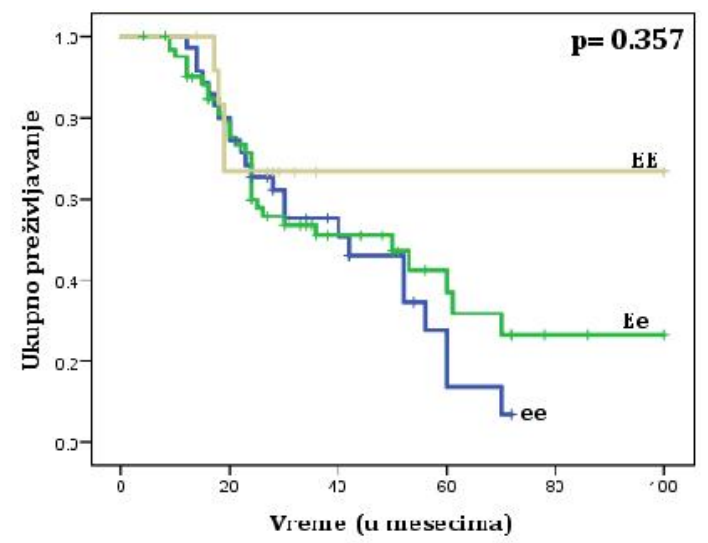

a)

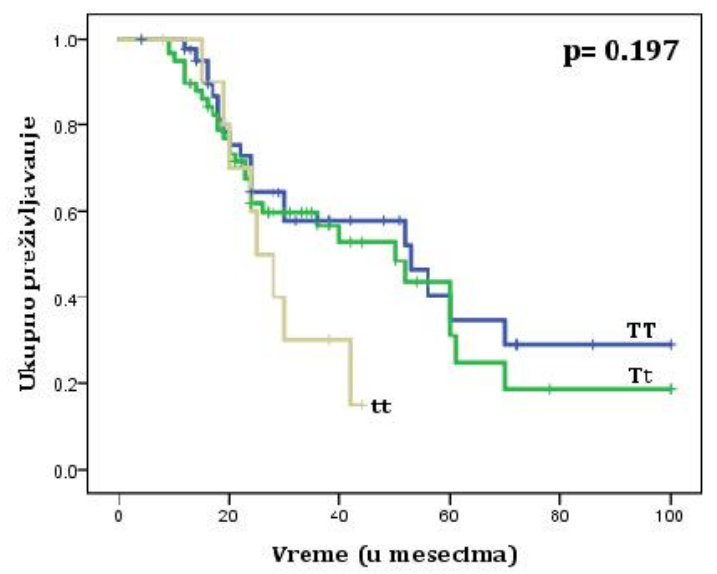

c)

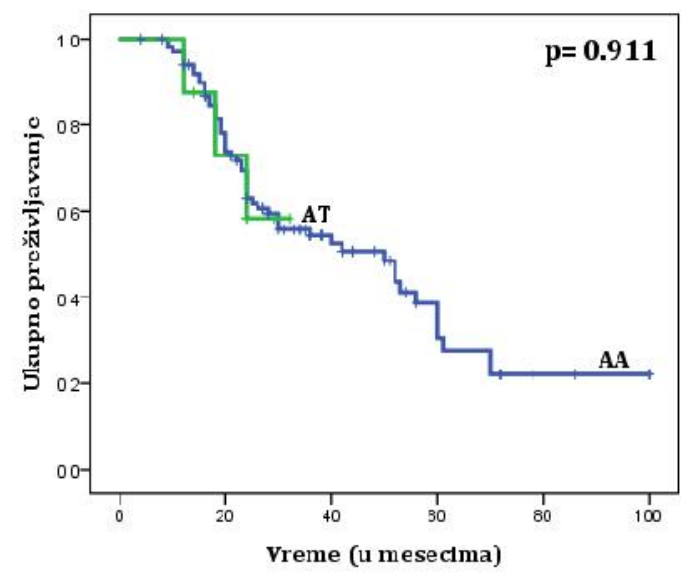

e)

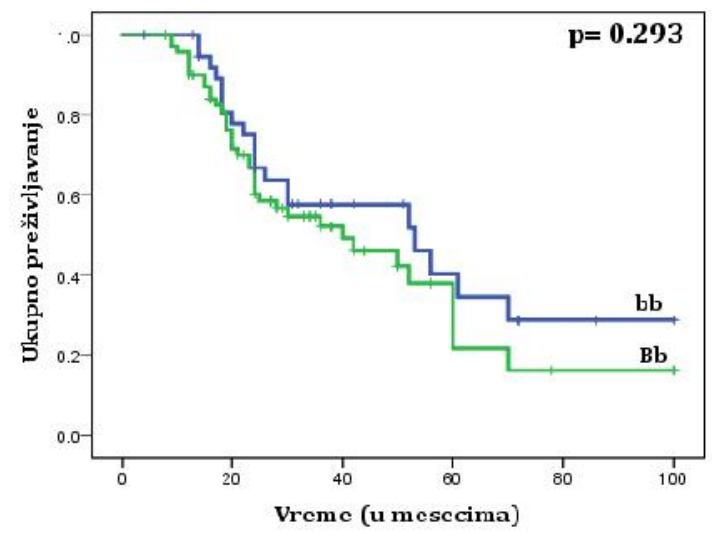

b)

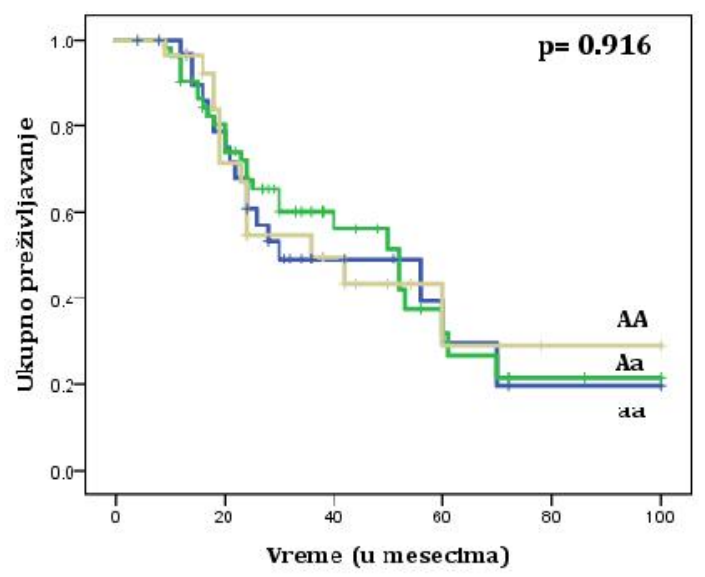

d)

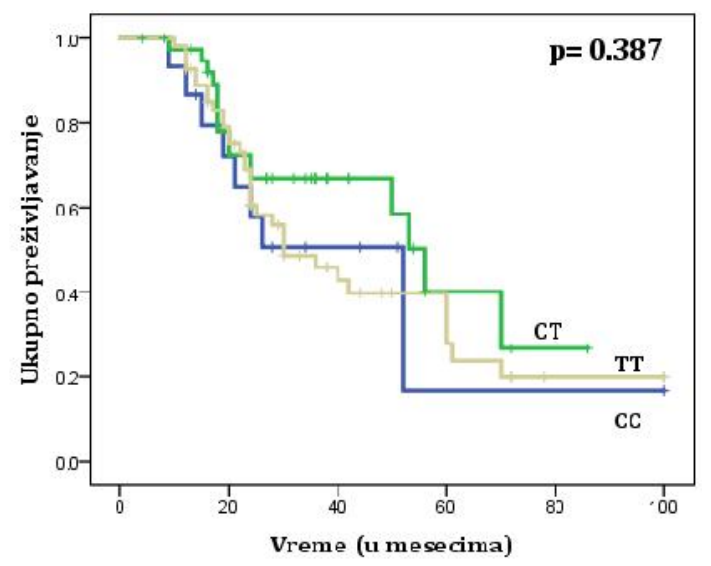

f)

Slika 35. Kaplan-Meier krive preživljavanja analiziranih polimorfizama: a) EcoRV b) BsmI c) TaqI d) ApaI e) VDR rs11574085 f) CYP27B1 rs4646536 
Grupisanje heterozigotnog i mutiranog genotipa za analizirane polimorfizme naspram divljih genotipova takođe nije bilo asocirano sa preživljavanjem. Isto je pokazano i stratifikovanom analizom prema stadijumu bolesti, veličini tumora, nodalnom statusu i recidivu bolesti (rezultati nisu prikazani). 


\subsection{Analiza promenljivih relevantnih za ukupno preživljavanje}

Univarijantna Cox regresiona analiza pojedinačnih promenljivih koje utiču na ukupno preživljavanje je pokazala da su VDR FokI polimorfizam, veličina tumora, stadijum bolesti, nodalni status, recidiv i nukleusni gradus, kao i oralna higijena i konzumiranje alkohola značajni prognostički indikatori za ukupno preživljavanje (Tabela 17).

Tabela 17. Univarijantna regresiona analiza pojedinačnih promenljivih koje utiču na ukupno preživljavanje

\begin{tabular}{|lcccc|}
\hline \hline Varijable & HR & $\mathbf{9 5} \% \mathbf{C I}$ & $\mathbf{p}^{*}$ \\
\hline VDR EcoRV & 0.754 & $(0.499-1.400)$ & 0.181 \\
VDR FokI & 0.615 & $(0.391-0.968)$ & $\mathbf{0 . 0 3 5}$ \\
VDR TaqI & 1.376 & $(0.909-2.085)$ & 0.132 \\
VDR ApaI & 0.975 & $(0.679-1.401)$ & 0.892 \\
VDR BsmI & 1.331 & $(0.771-2.299)$ & 0.304 \\
VDR rs11574085 & 1.068 & $(0.330-3.458)$ & 0.912 \\
CYP27B1 rs4646536 & 1.052 & $(0.723-1.530)$ & 0.792 \\
CYP24A1 rs2296241 & 1.538 & $(0.897-2.637)$ & 0.118 \\
Pol & 0.652 & $(0.350-1.215)$ & 0.178 \\
Godine & 1.307 & $(0.779-2.193)$ & 0.311 \\
Pušenje & 1.802 & $(0.912-3.563)$ & 0.090 \\
Alkohol & 1.544 & $(1.129-2.112)$ & $\mathbf{0 . 0 0 7}$ \\
Stadijum & 2.774 & $(1.257-6.122)$ & $\mathbf{0 . 0 1 2}$ \\
Nodalni status & 2.977 & $(1.277-6.939)$ & $\mathbf{0 . 0 1 2}$ \\
Veličina tumora & 2.636 & $(1.475-4.711)$ & $\mathbf{0 . 0 0 1}$ \\
\hline \hline Vrednostip 0.05 supodifa & & & \\
\hline
\end{tabular}

*Vrednosti $\mathrm{p}<0.05$ su podebljane 
Statistički značajne varijable u univarijantnoj analizi, uključujući varijable sa nivoom značajnosti ispod $20 \%(0.2)$ su ponovo analizirane zajedno u multivarijantnoj analizi. S obzirom da su nodalni status i veličina tumora uključeni u određivanje stadijuma bolesti, ove dve varijable su isključene iz multivarijantne analize u cilju dobijanja što preciznijih rezultata (Tabela 18.).

Tabela 18. Multivarijantna regresiona analiza više promenljivih koje utiču na ukupno preživljavanje

\begin{tabular}{|c|c|c|c|}
\hline Varijable & HR & $95 \% \mathrm{CI}$ & $\mathbf{p}^{*}$ \\
\hline VDR FokI & 0.580 & $(0.365-0.923)$ & 0.021 \\
\hline Alkohol & 1.477 & $(1.080-2.020)$ & 0.211 \\
\hline Stadijum & 2.656 & $(1.197-5.894)$ & 0.016 \\
\hline
\end{tabular}

*Vrednost $\mathrm{p}<0.05$ su podebljane

Multivarijantnom Cox regresionom analizom je pokazano da su VDR FokI polimorfizam i stadijum bolesti zadržali statistički značajan uticaj kao nezavisni prognostički faktori za ukupno preživljavanje, dok je doprinos unosa alkohola kao prognostičkog faktora izgubljen (Tabela 18.). 


\subsection{Analiza asocijacije haplotipova i preživljavanja}

Korišćenjem programa Thesias 3.1. je analizirano postojanje veze između procenjenih VDR haplotipova i ukupnog preživljavanja, Cox proporcionalnim

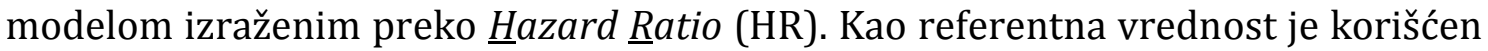
baT haplotip koji se javlja sa najvišom učestalošću u grupi pacijenata. U poređenju sa referentnom vrednošću, nije uočeno postojanje značajne veze između preostalih detektovanih haplotipova unutar grupe pacijenata sa dijagnostikovanim OSCC-om i preživljavanja (Tabela 19.). U slučaju asocijacije bat haplotipa i preživljavanja, uočava se trend $(\mathrm{p}=0.075)$, ali ta vrednost nije dostigla nivo statističke značajnosti (Tabela 19.).

Tabela 19. Asocijacija haplotipova sa preživljavanjem

\begin{tabular}{|lccc|}
\hline \hline Haplotip & HR & 95 \% CI & p \\
\hline \hline baT & Ref. & & \\
BAt & 1.211 & $(0.653-2.244)$ & 0.543 \\
bAT & 1.078 & $(0.637-1.823)$ & 0.778 \\
bat & 2.095 & $(0.929-4.726)$ & 0.075 \\
Bat & 2.173 & $(0.850-5.553)$ & 0.105 \\
bAt & 1.366 & $(0.454-4.109)$ & 0.578 \\
BAT & 2.291 & $(0.509-10.315)$ & 0.280 \\
BaT & 1.961 & $(0.339-11.392)$ & 0.451 \\
\hline
\end{tabular}

Ref.- Referentna vrednost 


\section{DISKUSIJA}


Oralna kancerogeneza predstavlja višestepeni proces koji uključuje složeno multifaktorsko preplitanje kako genetičkih tako i sredinskih faktora. Oralni skvamocelularni karcinomi se odlikuju lošom prognozom i visokim mortalitetom, kao i rastućom incidencom među osobama mlađim od 40 godina. Uprkos uloženim naporima za unapređenje dijagnostike i terapije, petogodišnje preživljavanje pacijenata sa dijagnostikovanim oralnim karcinomom je ostalo nepromenjeno poslednjih nekoliko decenija (Mascolo i sar., 2012), što ukazuje na potrebu za ulaganje u nove kriterijume klasifikacije ovog karcinoma. Poseban značaj se pridaje opisivanju molekularno genetičkih aspekta oralne kancerogeneze koji bi poslužili za pronalaženje dobrih prediktivnih i prognostičkih molekularnih markera. Polimorfizmi nukleotidne sekvence predstavljaju prirodne varijacije koje se smatraju odgovornim za razlike koje postoje među individuama po pitanju podložnosti bolestima, pa samim tim i karcinomima. U današnje vreme je sve veći broj studija koje imaju za cilj otkrivanje različitih polimorfizama u kandidat genima, koji bi mogli imati bitnu ulogu terapeutskih, prediktivnih ili prognostičkih faktora. Studije asocijacija identifikovanih polimorfizama kandidat gena i karcinoma, uključujući i GWAS projekat, ukazuju na značaj ovih genetičkih varijanti u humanom genomu i njihovu vezu sa podložnošću kompleksnim bolestima. Istovremeno se velike nade ulažu u identifikaciju prirodnih supstanci koje imaju antikancerogeno dejstvo, čija bi primena pokazala dobre rezultate, posebno kod onih osoba koje imaju povišen rizik za oboljevanje od različitih tipova karcinoma. Mnogobrojne in vitro i in vivo studije su pokazale da vitamin D ima antikancerogeni potencijal koji ostvaruje nakon vezivanja za svoj receptor (Deeb i sar., 2007; Stewart i Weigel, 2004; Kornfehl i sar., 1996). Aktivnost vitamina D je modulisana enzimima familije citohroma P450 koji su uključeni u njegov metabolizam. Prethodnim studijama je pokazano da su polimorfizmi u VDR genu, koji kodira za receptor za vitamin D, asocirani sa nekoliko tipova kancera, uključujući karcinome glave i vrata (Liu i sar., 2005), kao i oralni karcinom (AboHanger i sar., 2008; Bektas-Kayhan i sar., 2010). Uvidom u literaturu nalazimo da studije asocijacije gena koji imaju ulogu u anabolizmu i katabolizmu vitamina D sa oralnim karcinomima nisu do sada rađene. 
U ovoj doktorskoj disertaciji je proučavana asocijacija nekoliko najčešće analiziranih polimorfizama VDR gena, kao i CYP27B1 i CYP24A1 gena, uključenih u metabolizam vitamina $\mathrm{D}$, sa rizikom za razvoj oralnog karcinoma, kliničko patološkim karakteristikama i preživljavanjem pacijenata. Po našem saznanju, analiza polimorfizama gena bitnih za metabolizam i funkcionisanje vitamina D kod pacijenata sa oralnim karcinomom nije do sada rađena u našoj populaciji. Brojne studije su ispitivale postojanje asocijacija između VDR polimorfizama i rizika za razvoj kancera, pretežno kancera dojke, prostate i kolona, ali dobijeni rezultati nisu konzistentni i niskog su stepena reproducubilnosti između studija. Relativno mali broj studija je ispitivao potencijalni prognostički značaj VDR polimorfizama kod pacijenata obolelih od karcinoma. Samo nekoliko studija je proučavalo asocijaciju izvesnih SNP-ova u VDR genu sa rizikom za nastanak karcinoma glave i vrata i oralnog karcinoma, dok, prema našem saznanju, ovo predstavlja prvu studiju koja se posebno bavila i utvrdila postojanje asocijacije VDR polimorfizama i OSCC preživljavanja, što će biti diskutovano u predstojećem tekstu.

U ovoj studiji su primećene značajne razlike u distribuciji genotipova VDR polimorfizama EcoRV ( $p=0.019)$, ApaI ( $p=0.013)$ i BsmI ( $p=0.025)$, kao i CYP24A1 rs2296241 ( $\mathrm{p}=0.025$ ) između grupe pacijenata sa oralnim karcinomom i kontrolne grupe osoba naše populacije bez dijagnostikovanog karcinoma. Uočena razlika u distribuciji polimorfizama između OSCC i kontrolne grupe ukazuje na moguću asocijaciju i važnu ulogu VDR i CYP24A1 gena u procesu oralne kancerogeneze.

\subsection{EcoRV polimorfizam}

Polimorfizam u VDR genu smešten na poziciji -1012 u 1a promotorskom regionu, EcoRV (rs4516035), predstavlja supstituciju timina citozinom. Prema našem saznanju, EcoRV polimorfizam je relativno slabo ispitivan u genetičkim studijama asocijacije sa složenim bolestima, pa samim tim i karcinomima. S obzirom da je reč o polimorfizmu koji se nalazi u promotorskom regionu VDR gena za koji se smatra da nema funkcionalni efekat, čini ovaj polimorfizam relativno neprivlačnim za ispitivanja ovog tipa. U našem istraživanju je zapaženo da postoji 
statistički značajna razlika $u$ distribuciji genotipova $(p=0.002)$ i alela $(p=0.019)$ EcoRV polimorfizma između grupe pacijenata sa dijagnostikovanim OSCC-om i pripadnika kontrolne grupe. Mutirani alel E je bio nešto više zastupljen među kontrolama (51\%) u odnosu na uzorke (40\%), dok je divlji tip alela e bio češći u uzoračkoj grupi (60\%) u odnosu na kontrolnu grupu (40\%). Prethodna ispitivanja su pokazala da je VDR EcoRV EE mutirani genotip asociran sa smanjenim rizikom od kutanog melanoma u odnosu na ee wt genotip (Povey i sar., 2007), dok rezultati druge studije pokazuju da je mutirani genotip povezan sa povišenim rizikom za razvoj malignog melanoma (Barroso i sar., 2008) i da je divlji e alel povezan sa povećanom podložnošću i lošijim ishodom malignog melanoma (Halsall i sar., 2009). Kada je reč o našem istraživanju, rezultati crude Odds Ratio, pokazuju da je mutirani E alel, kao i EE varijanta EcoRV polimorfizma bila povezana sa 0.341 puta sniženim rizikom za razvoj oralnog karcinoma u poređenju sa wild type ee varijantom, ali je ova značajnost izgubljena nakon analize modifikovane prema polu, godinama, pušenju i unosu alkohola. Kako se rezultati adjusted Odds Ratio logističke regresione analize smatraju preciznijom merom za procenu rizika, može se reći da naši rezultati negiraju postojanje asocijacije između EcoRV polimorfizma i rizika za nastanak oralnog karcinoma, što je u skladu sa nalazima za kancer dojke (Barroso i sar., 2008) i za kancer dojke u populaciji Poljaka (Gapska i sar., 2009). EcoRV polimorfizam je bio asociran sa povećanim rizikom za pojavu melanoma lociranim na glavi, vratu i trupu (Barroso i sar., 2008). Pored toga, u kanceru dojke je EcoRV polimorfizam povezan sa smanjenim rizikom za metastaziranje (Barroso i sar., 2008), dok je u slučaju malignog melanoma $w t$ alel e bio asociran sa rizikom za metastaziranje (Halsall i sar., 2009). Stiče se utisak da su rezultati ovih malobrojnih istraživanja, koja su se bavila EcoRV polimorfizmom, potpuno oprečna, što se može dovesti u vezu sa tumorskom specifičnošću. EcoRV polimorfizam nije bio u vezi sa ispitivanim kliničko patološkim odlikama oralnog karcinoma u našem istraživanju.

Prema našem saznanju, ni jedna studija se do sada nije bavila proučavanjem veze između EcoRV polimorfizma i preživljavanja pacijenata sa oralnim karcinomom i karcinomom uopšte. EcoRV polimorfizam nije bio statistički povezan sa preživljavanjem $u$ našoj studiji $(p=0.357)$ i isto je pokazano i 
stratifikacionom analizom prema stadijumu bolesti, nodalnom statusu, veličini tumora i recidivu. Pored toga, univarijantna Cox-regresiona analiza je pokazala da se ovaj polimorfizam ne može koristiti kao nezavisni prognostički faktor.

\subsection{FokI polimorfizam}

Najčešće proučavani polimorfizam u VDR genu, FokI (rs2228570) se nalazi u egzonu 2 i predstavlja izmenu timina citozinom na poziciji +27823 (ili +30875 ). Reč je o jednom od retkih polimorfizama u VDR genu za koji je potvrđeno da ima funkcionalni efekat. Divlja ff forma rezultuje sintezom proteina koji se sastoji od 427 amino kiselina (M1 forma) za koju je pokazano da ima manji transaktivacijski kapacitet u odnosu na mutiranu varijantu FF, koja dovodi do sinteze proteina kraćeg za 3 amino kiseline (M4 forma) (Whitfield i sar., 2001). Ovom doktorskom disertacijom nije utvrđeno postojanje razlike $u$ distribuciji genotipova i alela između uzoračke i kontrolne grupe. Pored toga nije pokazano postojanje statističke veze između FokI polimorfizma i kliničko patoloških karakteristika, kao i rizika za razvijanje oralnog karcinoma. Istraživanjima koja su nedavno sprovedena nije utvrđeno postojanje asocijacije između VDR FokI polimorfizma i rizika za pojavu krupnoćelijskog karcinoma pluća (Turna i sar., 2012), prostate (Ahn i sar., 2009, Li i sar., 2007; Mikhak i sar., 2007), nazofaringealnog karcinoma u populaciji Han Kineza (Huang i sar., 2011) i kolorektalnog karcinoma u Iranskoj populaciji (Mahmoudi i sar., 2011), što je u konzistenciji sa našim rezultatima. Međutim, rezultati jedne istraživačke grupe su pokazali da je mutirana homozigotna FF varijanta povezana sa sniženim rizikom za razvoj karcinoma glave i vrata kod nehispanskih belaca (Liu i sar., 2005). U populaciji Poljaka, osobe divljeg ff genotipa su bile pod značajno povećanim rizikom za nastanak karcinoma dojke (Gapska i sar, 2009). Studija koja je obuhvatala pacijente sa dijagnostikovanim kancerom prostate, Kavkazoidne populacije, pokazuje da je prisustvo divljeg f alela bilo asocirano sa povećanim rizikom od nastanka agresivnog kancera prostate i stoga povezivano i sa lošijom prognozom (Xu i sar., 2003; Zhou i sar., 2006). Takođe, sprovedena meta analiza pokazuje da je divlji ff genotip asociran sa povećanjem 
rizika za razvoj kancera kože i dojke u poređenju sa FF mutiranim genotipom (Raimondi i sar., 2009). Različita zapažanja među studijama, po pitanju postojanja asocijacije FokI polimorfizma i rizika za razvoj karcinoma se mogu pripisati specifičnostima različitih tipova karcinoma, ali i veličini studijske grupe. Istraživanje koje se bavilo ispitivanjem povezanosti polimorfizama VDR gena i preživljavanja u slučaju krupnoćelijskog karcinoma pluća je utvrdilo da pojedinačni polimorfizmi nisu povezani sa preživljavanjem, ali je bolje preživljavanje uočeno u slučaju združenog efekta protektivnih alela tri polimorfizma VDR gena: FokI, BsmI i Cdx-2 (Zhou i sar., 2006).

Naši rezultati pokazuju da OSCC pacijenti sa divljom ff formom VDR FokI polimorfizma imaju značajno lošiju stopu preživljavanja u poređenju sa heterozigotnim i mutiranim genotipom zajedno $(p=0.012)$. Ovo zapažanje je $u$ skladu sa rezultatima prethodnih studija prema kojima je ff genotip asociran sa lošim preživljavanjem u slučaju karcinoma glave i vrata (Hama i sar., 2011), uznapredovalog krupnoćelijskog karcinoma pluća (Heist i sar., 2008) i epitelijalnog kancera ovarijuma (Tamez i sar., 2009). Ovakvi rezultati podržavaju podatke koji govore o funkcionalnosti FokI polimorfizma. Poznato je da je prisustvo divljeg $f$ alela asocirano sa smanjenom VDR ekspresijom i VDR funkcionalnom aktivacijom nakon izlaganja kalcitriolu (Colin i sar., 2000). M1 forma receptora za vitamin D, koji nastaje kao rezultat postojanja FokI divljeg genotipa, ima manji kapacitet transaktivacije, što može rezultovati progresijom bolesti i posledično lošim ishodom (Zeljic i sar., 2012). Nedavno publikovano istraživanje ukazuje da je rast ćelijske linije kancera dojke MCF-7 VDR FF genotipa bio 60\% inhibiran kao posledica tretmana kalcitriolom, u poređenju sa ćelijskim linijama ff genotipa, čiji je rast bio inhibiran za samo 28\% (Alimirah i sar., 2011). Pretpostavlja se da VDR M4 proteinska forma ima veći kapacitet da indukuje ekspresiju CYP24A1 gena u poređenju sa M1 formom (Roff i sar., 2008). U skladu sa ovom pretpostavkom, u ćelijama FF genotipa je nivo iRNK CYP24A1 gena bio 1.8 puta viši (Alimirah i sar., 2011). Istovremeno, zabeleženo je da je nivo iRNK CYP24A1 gena i proteina bio značajno povišen u odgovoru na kalcitriol u slučaju ćelija FF genotipa u poređenju sa ćelijama ff genotipa, što dodatno potvrđuje zaključak o intenzivnijem odgovoru na vitamin D u slučaju FF genetičke varijante (Alimirah i sar., 2011). Jedan od 
mogućih predloženih mehanizama kojima FF varijanta pojačava efikasnost vitamina D je povećanje stabilnosti proteinskog receptora. Naime, ćelije FF genotipa su bile rezistentne na efekte inhibitora proteinske sinteze, cikloheksamida, iako nisu bile izložene tretmanu kalcitriolom. Poznato je da je $\mathrm{N}$-terminalna sekvenca proteina često determinanta njegove stabilnosti, te je moguće da različita proteinska stabilnost M1 odnosno M4 VDR forme može biti rezultat njihove razlike u N-terminalnoj sekvenci (Jurutka i sar., 2000; Alimirah i sar., 2011). Proteinska stabilnost receptora i viša aktivnost FF genetičke varijante doprinosi da ova varijanta pojačava odgovor na vitamin $\mathrm{D}$ u ćelijama kancera dojke (Alimirah i sar., 2011). Nasuprot ovome, ćelijske linije kancera tireoidee ff genotipa su pokazale senzitivnost pri izlaganju kalcitriolu u poređenju sa rezistentnim ćelijama, koje su bile FF genotipa (Sharma i sar., 2010). Primećene diskrepance u slučaju kancera tireoidee i oralnog karcinoma se mogu pripisati tkivnoj specifičnosti i drugačijoj patogenezi, iako se oba navedena karcinoma razvijaju od skvamocelularnog epitela. Kao mogući zaključak se nameće da divlji ff genotip može imati značajnu ulogu u pojačanju agresivnosti kancera i samim tim biti povezan sa lošijom prognozom i ukupnim preživljavanjem. Istovremeno, time bi se moglo objasniti zašto neke ćelije kancera nedovoljno reaguju na tretman vitaminom D (Alimirah i sar., 2011). Ipak, bitno je naglasiti da se pretpostavlja da snižena transaktivacijska sposobnost M1 forme nije sama po sebi dovoljna da inicira nastajanje bolesti, ali ima mogućnost da unapredi razvoj bolesti (Gapska i sar., 2009). U prilog tome govore i rezultati istraživanja koja potvrđuju da je samo u slučaju niske koncentracije $25(\mathrm{OH}) \mathrm{D}_{3}$ u serumu, divlji ff genotip bio povezan sa 2.53 puta povećanim rizikom za nastanak agresivne forme kancera prostate (Li i sar., 2007), što ukazuje na postojanje interakcije između genotipa i sredinskih faktora. Obrnuto, u slučaju visokog nivoa kalcidiola i FokI ff genotipa rizik od nastanka agresivne forme kancera prostate je bio snižen za 60-70\% (Li i sar., 2007). Budući da nemamo podatke o nivou glavne cirkulišuće forme vitamina $D$ u serumu naših pacijenata u studiji, postoji mogućnost da su upravo osobe ff genotipa imale nizak nivo kalcidiola, prema literaturnim podacima niži od $25 \mathrm{ng} / \mathrm{ml}$, što je rezultovalo značajno lošijim preživljavanjem uočenim u ovom istraživanju. Pored toga, mutirana FF varijanta je asocirana sa sniženim rizikom za 
razvoj karcinoma prostate u slučaju visokog stepena izloženosti Sunčevom zračenju i svetlije pigmentacije kože (John i sar., 2005; Ingles, 2007). Muškarci ff genotipa Britanske populacije su bili pod čak 3 puta višim rizikom za razvoj kancera prostate samo ukoliko su bili izloženi Sunčevom zračenju manje od prosečnog vremena od 1100 sati godišnje (Bodiwala i sar., 2004). Ovakvi podaci nam nedvosmisleno pokazuju koliko je veliki značaj sredinskih faktora, pored genetičke osnove, u determinaciji složenih fenotipskih osobina i time kompleksnih bolesti uključujući i kancer, koje bi trebalo uzeti u razmatranje u budućim proširivanjima ove studije.

Multivarijantna analiza Cox regresionim modelom je pokazala da FokI polimorfizam VDR gena može biti razmatran kao nezavisan prognostički faktor (HR=0.580, p=0.021). Dodatno, mi smo pokazali da je FokI ff genotip značajno asociran sa lošom prognozom u slučaju OSCC pacijenata sa i bez metastaza limfnih čvorova ( $\mathrm{p}=0.040, \mathrm{p}=0.025$, redom), kao i podgrupe pacijenata u III stadijumu bolesti ( $p=0.026)$, dok u stadijumu II, FokI nije imao prognostički značaj $(p=0.079)$. Prema literaturnim podacima, smatra se da maligne ćelije mogu razviti izvesni mehanizam za izbegavanje antiproliferativnih dejstava vitamina D, uključujući smanjenje VDR ekspresije, smanjenje konverzije $25(\mathrm{OH}) \mathrm{D}_{3}$ u $1 \alpha 25(\mathrm{OH})_{2} \mathrm{D}_{3}$ ili povećanje ekspresije CYP24A1 gena. Pretpostavlja se da taj kapacitet za izbegavanje antiproliferativnih dejstava vitamina D može biti više zastupljen među ćelijama u uznapredovalom tumorskom stadijumu (Heist i sar., 2008; Bouillon i sar., 2006), čime bi se mogla objasniti uočena veza sa lošijim preživljavanjem u III stadijumu bolesti u slučaju $w t$ ff genotipa u našem istraživanju. Dodatno, pokazano je da su osobe ff genotipa pod većim rizikom od nastajanja metastaza u slučaju kancera dojke u populaciji Britanaca (Osborne i Hutchinson, 2002). Ovaj nalaz bi se mogao povezati sa našim zapaženjem statistički značajno lošijeg preživljavanja pacijenata ff genotipa u odnosu na nodalni status.

Značajno je pomenuti i zapažanje da je kod ćelija ff genotipa zabeležena povišena ekspresije proinflamatornih gena COX-2, IL-8, CCL-2 i BIRC-3 (Alimirah i sar., 2011). Prema skorašnjim podacima smatra se da COX-2 gen ima bitnu ulogu u metastazi ćelija kancera. Utvrđeno je da je upravo COX-2 jedan od gena odgovornih za pokretanje metastaze ćelija kancera dojke u mozak, pluća (Bos 
i sar., 2009; Minn i sar., 2005; Alimirah i sar., 2011) i kosti (Singh i sar., 2006). Povišen nivo expresije COX-2 i IL-8, detektovan kod pacijenata sa kancerom dojke (Singh i sar., 2006) bio je pozitivno povezan sa nepovoljnom prognozom i ubrzanom progresijom bolesti koja na kraju rezultira metastazom (Alimirah i sar., 2011). Time bi se mogla objasniti i naša zapažanja o lošijem preživljvanju pacijenata ff genotipa u odnosu na pozitivni nodalni status. Iz prethodno iznetih podataka bi se moglo zaključiti da COX-2 i IL-8 geni na izvestan način potpomažu invaziju ćelija kancera ff genotipa u druge organe (Alimirah i sar., 2011). Dakle, povišena ekspresija proinflamatornih gena, zajedno sa ff genotipom bi mogla potencijalno poslužiti kao klinički marker za agresivnost tumora i prognozu. Prema sugestijama datim $u$ istoimenom istraživanju, bitno je napomenuti da VDR ff genetička varijanta sama po sebi ne uzrokuje agresivni fenotip, ali usled povećanja transkripcione aktivnosti gena koji su u vezi sa agresivnim fenotipom, normalne ćelije će podleći procesu kancerogeneze tokom vremena (Alimirah i sar., 2011). Povišen nivo expresije BIRC-3 gena u slučaju ćelija ff genotipa ukazuje da ćelije kancera sa ovim genotipom mogu izbeći apoptozu, doprinoseći posledično nepovoljnoj prognozi (Alimirah i sar., 2011). Buduća istraživanja u našoj studijskoj grupi bi mogla da obuhvate $\mathrm{i}$ analizu ekspresije prethodno navedenih proinflamatornih gena, što bi se moglo dovesti u vezu sa rezultatima dobijenim za FokI polimorfizam i oralni karcinom.

\subsection{TaqI polimorfizam}

Na 3' kraju VDR gena, u egzonu 9 je identifikovan polimorfizam TaqI (rs731236) koji predstavlja supstituciju timina citozinom na poziciji +61938. Reč je o tihoj (engl. silent) izmeni kodona ATT u ATC, gde oba kodona kodiraju za ugradnju izoleucina na pozicijji 352 u polipeptidnom lancu (Thorne i Campbell, 2008). TaqI polimorfizam se najčešće proučava u sklopu haplotipskog bloka, s obzirom da se nalazi u jakoj neravnoteži vezanosti sa ApaI i BsmI polimorfizmom, ali je i individualni efekat TaqI polimorfizma ispitivan u različitim karcinomima. U ovom istraživanju nije detektovano postojanje razlike u distribuciji genotipova i 
alela TaqI polimorfizma između grupe OSCC pacijenata i kontrola. Što se tiče veze sa kliničko patološkim odlikama, naši rezultati ukazuju da je TaqI polimorfizam značajno povezan sa polom ( $\mathrm{p}=0.006)$, pušačkim statusom $(\mathrm{p}=0.039)$ i pojavom recidiva ( $\mathrm{p}=0.008)$. Mutirani $\mathrm{i}$ heterozigotni genotip su bili zastupljeniji među pripadnicima muškog (70\%) u odnosu na ženski pol (50\%). Literaturni podaci ukazuju da je oralni karcinom češći među pripadnicima muškog u odnosu na ženski pol (Jemal i sar., 2011). Tradicionalno se ovakva polna distribucija u javljanju oralnog karcinoma povezivala sa višom zastupljenošću pušenja i konzumacije alkohola među pripadnicima muškog pola (Silverman, 2001). U današnje vreme se razlika u učestalosti OSCC-a između polova snižava, što se najčešće objašnjava sve zastupljenijom upotrebom cigareta i/ili alkohola među ženama. Međutim, moguće je da pored ovih dobro poznatih faktora rizika, genotip TaqI polimorfizma igra izvesnu indirektnu ulogu u razvijanju oralnog karcinoma, čime bi se mogao objasniti rastući broj dijagnostikovanih oralnih karcinoma među pripadnicama ženskog pola. Takođe, pušenje je bilo značajno povezano sa TaqI polimorfizmom i to heterozigotnom i mutiranom varijantom zajedno, koje su bile daleko zastupljenije u grupi nepušača i bivših pušača, u poređenju sa divljom formom.

Mi nismo registrovali postojanje veze između TaqI VDR SNP-a i rizika za razvoj oralnog karcinoma što je u skladu sa rezultatima dobijenim za kancer prostate u populaciji nehispanskih belaca (Ahn i sar., 2009; Tayeb i sar., 2003), kancer prostate u populaciji Afro Amerikanaca (Bonilla i sar., 2011) i kolorektalni karcinom u populaciji Čeha (Hughes i sar., 2011). Međutim, druge studije pokazuju drugačije nalaze. Mutirani homozigot VDR TaqI polimorfizma je bio asociran sa smanjenim rizikom za razvoj karcinoma glave i vrata kod ne-hispanskih belaca (Liu i sar., 2005). Isti rezultati za TaqI polimorfizam su dobijeni za populaciju Egipćana, OSCC pacijenata (Abo-Hanger i sar., 2008). U studiji sprovedenoj na Turskoj populaciji, heterozigotne varijante TaqI polimorfizma su asocirane sa smanjenim rizikom za nastanak oralnog skvamocelularnog karcinoma (BektasKayhan i sar., 2010). Kada je reč o drugim kancerima, divlji TT genotip TaqI polimorfizma je bio asociran sa povećanim rizikom za razvoj krupnoćelijskog karcinoma pluća (Turna i sar., 2012) i pet puta višim rizikom za nastanak 
metastaza u slučaju karcinoma prostate i dojke (Garland i sar., 2004). Sa druge strane, TaqI nije pokazao značajnu asocijaciju sa kancerom prostate ili benignim hiperplazijama u populaciji Japanaca (Habuchi, i sar. 2000), što odgovara zapažanjima za kancer prostate u populaciji Kavkazijanaca (Holick i sar., 2007). Može se pretpostaviti da ovakvi nekonzistentni rezultati između studija odslikavaju razlike u učestalosti alela između različitih populacija. Inače, minor alel TaqI polimorfizma je daleko zastupljeniji među Kavkazijancima u poređenju sa Azijatima i Afrikancima. Smatra se da relativno novi polimorfizmi mogu pokazivati visok stepen varijacije među etničkim grupama (Uitterlinden i sar., 2004). Pored toga, faktore spoljašnje sredine, kao što je UV zračenje, bi trebalo uzeti u razmatranje kao potencijalni uzrok nekonzistentnih rezultata među studijama. Pokazano je da je značajno sniženje rizika za razvoj karcinoma prostate u vezi sa tt genotipom TaqI polimorfizma u slučaju većeg izlaganja Suncu i provođenja vremena napolju (John i sar., 2005). Takođe, ne treba zanemariti efekat veličine uzorka i odabira pacijenata za studiju, što takođe može uticati na uočene razlike između istraživanja.

Što se tiče preživljavanja, u našem istraživanju nije pronađena veza sa TaqI polimorfizmom, ni nakon stratifikovane analize prema nodalnom statusu, stadijumu bolesti i postojanju recidiva.

\subsection{ApaI polimorfizam}

Nedaleko od TaqI polimorfizma, $u$ intronu 8 na poziciji +61888 je identifikovana izmena citozina adeninom, poznatija kao ApaI polimorfizam. Ovim istraživanjem je pokazano da je mutirani alel A značajno povezan sa 0.645 puta smanjenim rizikom za razvoj oralnog karcinoma u poređenju sa divljim a alelom $(\mathrm{p}=0.019)$. Nasuprot našim nalazima, nosioci mutiranog alela A ApaI polimorfizma su imali povećani rizik za razvoj kancera ovarijuma u Kavkazoidnoj populaciji, što nije bio slučaj u populaciji žena iz Japana (Lurie i sar., 2007). Takođe, mi smo zabeležili značajno smanjenje rizika od 0.486 puta kod mutiranog genotipa AA grubom logističkom regresionom analizom. Međutim, modifikovanom logističkom 
regresijom je ova značajnost izgubljena, što ukazuje na značaj kofaktora: godina, pola, pušenja i unosa alkohola. Takvo zapažanje je u konzistenciji sa nalazima za melanom (Schafer i sar., 2012). U slučaju kolorektalnog karcinoma, odsustvo asocijacije je zabeleženo za pripadnike Češke populacije (Hughes i sar., 2011) i Kavkazijanaca uopšte (Kupfer i sar., 2011), dok je ApaI je bio značajno povezan u populaciji Afro Amerikanaca. Takođe su primećene razlike u asocijaciji populacija Afro Amerikanaca iz različitih geografskih regiona, te se postojanje takvih razlika može objasniti razlikama u izloženosti sredinskim faktorima između ovih grupa (Kupfer i sar., 2011). U populaciji Japanaca (Habuchi i sar., 2000) ApaI SNP nije pokazao značajnu asocijaciju sa kancerom prostate niti benignim hiperplazijama, što je potvrđeno i drugim istraživanjima čiju su studijsku grupu činili Kavkazijanci (Ahn i sar., 2009). Sa druge strane u Turskoj populaciji (Hacer Onen i sar., 2008) ApaI heterozigoti Aa i mutirani AA genotipovi su asocirani sa povećanim rizikom za nastanak sporadičnog kancera prostate. Pored VDR polimorfizama, pokazano je da u etiologiji kancera prostate, važnu ulogu imaju i sredinski faktori, kao što je izlaganje Suncu (John i sar., 2005), čime se mogu pojasniti uočene razlike.

Starosna dob se navodi kao bitan faktor u oralnoj kancerogenezi, s obzirom da je incidenca oralnog karcinoma viša u kasnijem životnom dobu. Međutim, noviji podaci pokazuju da je veliki broj pacijenata identifikovan u grupi ispod 40 godina starosti, koji čak nisu izloženi nekim od poznatih faktora rizika, što ostavlja prostor za razmatranje genetičke osnove koja bi u takvim situacijama predstavljala okidač za nastanak oralnog karcinoma. Naime, u našoj grupi OSCC pacijenata, zapažena je veza između VDR ApaI polimorfizma i godina, prema medijani starosti od 58 godina ( $\mathrm{p}=0.049)$. Značajno viša zastupljenost heterozigota i mutiranog genotipa zajedno u odnosu na divlju formu je detektovana među pacijentima starijim od 58 godina, kao i u odnosu na mlađe od 58 godina svih genotipskih varijanti. Time je moguće dovesti u vezu Aa i AA genotip sa godinama kod oralnog karcinoma. Ovakav nalaz se možda ne odnosi direktno na proces starenja već može biti i rezultat dužeg perioda konzumacije alkohola i pušenja, koji je evidentiran u grupi pacijenata sa OSCC karcinomom. 


\subsection{BsmI polimorfizam}

BsmI polimorfizam, smešten u intronu 8, između egzona 8 i 9, predstavlja izmenu timina citozinom na mestu +60890 . S obzirom da je reč o izmeni koja ne dovodi do promene amino kiselinske sekvence, pretpostavlja se da nema funkcionalni efekat. Međutim, utvrđeno je da se BsmI nalazi u jakom LD-u sa poly A repom i da može uticati na nivo ekspresije menjanjem stabilnosti iRNK (Denzer i sar., 2011; Parisi i sar., 2008).

Uočili smo da između grupe pacijenata sa dijagnostikovanim oralnim karcinomom i kontrolne grupe postoji značajna razlika u distribuciji genotipova $(p=0.025)$ ali ne i alela $(p=0.260)$. Interesantno je zapažanje da unutar OSCC grupe nisu zabeleženi nosioci mutiranog BB genotipa, dok su u kontrolnoj grupi detektovani u malom procentu (2.4\%). Heterozigotna forma $\mathrm{Bb}$ je bila zastupljenija među obolelima (64.5\%) u odnosu na kontrole (49.2\%). Pored toga, naši rezultati ukazuju da je BsmI značajno povezan sa polom $(\mathrm{p}=0.002)$. Crude Odds Ratio je pokazao da je heterozigotna varijanta, kao i združeni heterozigot i mutirani genotip statistički značajno povezani sa 1.790 puta povećanim rizikom za nastanak oralnog karcinoma. Nakon adjusted Odds Ratio analize, ova statistička značajnost je izgubljena. To je u skladu sa nedavnim zapažanjem nepostojanja asocijacije između BsmI polimorfizma i rizika od pojave karcinoma prostate (Ahn i sar., 2009; Mikhak i sar., 2007), nazofaringealnog karcinoma u populaciji Han Kineza (Huang i sar., 2011), kolorektalnog karcinoma u populaciji Čeha (Hughes i sar., 2011) i Iranskoj populaciji (Mahmoudi i sar., 2011). Jednom studijom je pokazano da je mutirani BB genotip značajno povezan sa povećanim rizikom za nastanak skvamocelularnih karcinoma (Han i sar., 2007). Međutim, u populaciji Japanaca BsmI polimorfizam je imao značajnu protektivnu ulogu u nastanku benignog kancera prostate (Habuchi i sar., 2000). Opsežna meta analiza je ukazala da Bb heterozigoti imaju značajno smanjeni rizik za nastanak kancera prostate u odnosu na divlji genotip. Prema istoimenoj meta-analizi, naglašeno je da je BsmI heterozigotni genotip kod Kavkazijanaca asociran sa značajnim smanjenjem rizika za razvoj kancera na bilo kom mestu (Raimondi i sar., 2009). Sa druge strane, ustanovljeno je postojanje veze između povećanog rizika za 
razvoj karcinoma prostate i bb genotipa BsmI polimorfizma samo u slučaju niske koncentracije kalcidiola u serumu (Ahn i sar., 2009; John i sar., 2005), što je potvrđeno i za karcinom dojke (Colston i sar., 2006). U Američkoj populaciji, bb genotip je povezan sa niskom koncentracijom kalcitriola u cirkulaciji i dva puta većim rizikom za nastanak karcinoma kolona kod muškaraca (Garland i sar., 2004). Ovakvi nalazi stavljaju akcenat na obavezno razmatranje sredinskih faktora $\mathrm{u}$ studijama asocijacije polimorfizama i rizika od kancerogeneze. Statistički značajno povećanje rizika za kancer dojke je primećeno kod žena sa $w t$ bb genotipom i poly A LL genotipom (Guyi sar., 2004). U studiji sprovedenoj na velikom uzorku žena u postmenopauzi, $w t$ bb genotip je bio asociran sa povećanim rizikom za kancer dojke kod Kavkazijanaca, ali ne i Afro-Amerikanki (Trabert i sar., 2007). Obe rasne grupe nisu pokazivale značajnu asocijaciju između poly A polimorfizma i rizika za kancer dojke, iako se poly A i BsmI polimorfizam nalaze u jakoj neravnoteži vezanosti (Uitterlinden i sar., 2004). Iz prethodno navedenog je jasno da su rezultati vrlo nekonzistentni među studijama, što se može pripisati etničkim različitostima kao i izloženostima faktorima spoljašnje sredine, koje bi trebalo uzeti u razmatranje prilikom izvođenja studija asocijacije. Takođe, u predstojećim ispitivanjima bi bilo poželjno uključiti i polimorfizam dužine poly A repa, koji bi u kombinaciji sa genotipovima BsmI polimorfizma mogao dati dodatne informacije za dobijene rezultate.

Kada je reč o proučavanju povezanosti polimorfizama VDR gena i prognoze, najproučavaniji je BsmI polimorfizam. U našoj studijskoj grupi BsmI polimorfizam nije bio u vezi sa preživljavanjem pacijenata. Prema rezultatima izvesnih istraživanja, mutirani BB genotip BsmI polimorfizma se povezivao sa zaštitom od razvoja metastaza kod pacijenata sa karcinomom dojke i bio povezivan sa prognozom kancera rektuma utičući na ekspresiju erbB-2 onkogena, koji nije samostalno imao uticaja na preživljavanje (Zhou i sar., 2006). Kod žena BB genotipa rizik od metastaziranja karcinoma dojke je bio četiri puta viši u odnosu na nosioce $w t$ genotipa (Garland i sar., 2004).

Drugim studijama nije utvrđeno postojanje asocijacije između genotipova analiziranih polimorfizama BsmI, ApaI, TaqI FokI i poly A sa karcinomom dojke, ali stratifikovana analiza prema ishrani je pokazala da osobe sa većim unosom 
kalcijuma imaju manji rizik ukoliko su BsmI bb, TaqI TT i poly A LL genotipa (McCullough i sar., 2007). Ovakva zapažanja predstavljaju dokaz više koji ukazuje na značaj faktora spoljašnje sredine, u ovom slučaju ishrane, u studijama asocijacije. S obzirom da se ishrana smatra vrlo značajnim faktorom koji može modifikovati podložnost karcinomima uopšte, pa samim tim i oralnom karcinomu, postojanje podataka o ishrani, a posebno unosu vitamina D i kalcijuma, bi bilo od izuzetnog značaja za analizu naših dobijenih rezultata.

\subsection{Analiza haplotipova}

Značaj pojedinačnih SNP-ova koji nisu pokazali postojanje veze na individualnom nivou sa rizikom za razvijanje kancera bi trebalo razmatrati i $\mathrm{u}$ analizama interakcije između SNP-ova. Istovremeno, treba imati na umu da se SNP-ovi mogu nalaziti u neravnoteži vezanosti i da je vrlo često uočena veza pojedinačnog polimorfizma sa bolešću zapravo rezultat postojanja haplotipskog bloka u kom se analizirani polimorfizam nalazi. Studije asocijacije su pokazale da proučavanje haplotipova ima veću statističku snagu u odnosu na proučavanje pojedinačnih SNP-ova (Bader, 2001). Stoga bi analiza haplotipova mogla da pokaže kako polimorfizmi u nekom genu mogu doprineti riziku za nastanak određenih kancera. Iz literature je poznato da se BsmI, ApaI i TaqI SNP-ovi VDR gena nalaze u jakom LD-u i čine B LD blok VDR gena (Uitterlinden i sar., 2004; Whitfield i sar., 2001). Haplotipskom analizom pomoću programa Haploview, je pokazano da su upravo ova tri polimorfizma u jakom LD-u u našoj celokupnoj studijskoj grupi, kao i u OSCC i kontrolnoj grupi. Najzastupljeniji haplotip u grupi pacijenata i osoba koje su činile kontrolnu grupu je bio baT, sa učestlošću oko 40\%, za kojim slede Bat i bAT, što odgovara prethodno zabeleženim učestalostima u drugim studijama (Denzer i sar., 2011). U studijskoj grupi koju su činili pripadnici Turske populacije haplotip baT je bio najviše zastupljen sa relativno sličnom učestalošću koja odgovara našim nalazima (Hacer Onen i sar., 2008). S obzirom da je poznato da haplotipski blokovi odslikavaju evolucionu istoriju humanih populacija, na osnovu tri navedena polimorfizma koji pripadaju B haplotipskom bloku VDR gena i koji se 
nalaze u jakom LD-u, moglo bi se reći da nije bilo dovoljno vremena za razdvajanje ovog bloka rekombinacijama, bar kada je reč o Evropskim populacijama. Identifikovani haplotipovi u našoj grupi nisu bili u asocijaciji sa rizikom nastanka oralnog karcinoma. Nepostojanje asocijacije ovog tri-lokusnog haplotipa sa kancerom prostate je zabeleženo za većinu Kavkazoidne populacije (Cicek i sar., 2006), ali je uvođenjem FokI polimorfizma u haplotipsku analizu pokazano smanjenje rizika. Prethodno istraživanje sprovendeno na Turskoj populaciji pacijenata sa sporadičnim kancerom prostate (Hacer Onen i sar., 2008) je pokazala da je Bat haplotip povezan sa smanjenjem rizika za nastanak kancera prostate. Inače, in vitro funkcionalne studije su pokazale da je baT haplotip povezan sa sniženom genskom aktivnošću i nižim nivoom VDR iRNK (Denzer i sar., 2011). Smatra se da Bat haplotip ima 140\% veću receptorsku aktivnost u poređenju sa baT haplotipom (Obara i sar., 2007). U populaciji Poljaka, BsmI i TaqI haplotipska forma BT je asocirana sa smanjenim rizikom za kancer dojke (Gapska i sar., 2009). Takođe je pronađeno da bL haplotip ima protektivnu ulogu u nastanku uznapredovalih kancera prostate kod Afro Amerikanaca (Osborne i Hutchinson, 2002).

Naši rezultati su pokazali da identifikovani haplotipovi u uzoračkoj grupi nisu $u$ vezi sa ukupnim preživljavanjem. Izvesni trend postoji u slučaju bat haplotipa, ali vrednost nije dostigla statističku značajnost $(\mathrm{p}=0.075)$. Ovo je prvi nalaz koji se bavio asocijacijom haplotipova u VDR genu i preživljavanja, s obzirom da do sada nije zabeleženo istraživanje tog tipa.

\subsection{VDR rs11574085 polimorfizam}

VDR rs11574085 polimorfizam, prema pretraživanju PubMed baze, do sada nije ispitivan u studijama asocijacije sa oralnim karcinomom i karcinomima uopšte. Nismo zabeležili postojanje razlike u učestalosti genotipova i alela između grupe pacijenata i kontrola. Rezultati su pokazali da ovaj SNP nije povezan sa kliničko patološkim karakteristikama, rizikom za nastanak oralnog karcinoma i preživljavanjem. Dobijeni negativni rezultati asocijacije rs11574085 polimorfizma 
u VDR genu i podložnosti oralnom karcinomu se mogu objasniti najverovatnije nefunkcionalnošću proučavanog polimorfizma i odsustva vezanosti sa drugim blisko lociranim polimorfizmima VDR gena.

\subsection{CYP27B1 polimorfizam}

S obzirom da je metabolizam vitamina D regulisan enzimima familije $\mathrm{P} 450$, za studiju su izabrani ključni geni koji kodiraju enzime uključene u anabolizam odnosno katabolizam vitamina D. CYP27B1 kodira $1 \alpha$-hidroksilazu, enzim koji ima ulogu u prevođenju glavne cirkulišuće forme vitamina $\mathrm{D}, 25(\mathrm{OH}) \mathrm{D}_{3}$, do metabolički aktivne forme vitamina D, kalcitriola. Proučavanje polimorfizma rs4646536 u CYP27B1 genu je potpuno relevantno za kancerogenezu, s obzirom na rezultate prethodnih studija prema kojima su neki drugi SNP-ovi u ovom genu asocirani sa nastankom kancera prostate (Holt i sar., 2010) i kolona (Dong i sar., 2009). Međutim, neke istraživačke grupe za rs4646536 polimorfizam nisu uočile postojanje asocijacije u slučaju kancera kolona (Dong i sar., 2009), prostate (Beuten i sar., 2009) i melanoma (Schafer i sar., 2012), što je u skladu sa rezultatima ove doktorske disertacije. S obzirom da je funkcionalni efekat proučavanog polimorfizma nepoznat, od izuzetnog značaja bi bilo određivanje ekspresije CYP27B1 gena u našoj grupi. Interesantan je podatak da nivo iRNK CYP27B1 gena nija bio promenjen u slučaju MCF-7 ćelijskih linija dojke nakon izlaganja kalcitriolu (Alimirah i sar., 2011). U našem istraživanju nije uočena značajna razlika u distribuciji alela i genotipova rs4646536 polimorfizma između OSCC i kontrolne grupe. Isto zapažanje je dato u slučaju daleko veće studijske grupe, koja je uključivala pacijente sa kancerom prostate (Hawkins i sar., 2002).

Pokazali smo da je CYP27B1 rs4646536 polimorfizam značajno povezan sa unosom alkohola ( $p=0.012$ ). Od ranije je poznato da alkohol i pušenje predstavljaju značajne faktore rizika za nastanak oralnog karcinoma. Osobe koje puše više od 20 cigareta dnevno i konzumiraju preko $100 \mathrm{~g}$ alkohola na dan, imaju povišen rizik od oralnih epitelijalnih displazija, ali i bivši pušači i alkoholičari (Kruse i sar., 2010). Pored toga, poznato je da alkohol predstavlja nezavisni faktor rizika među 
nepušačima, a duvanski dim među nealkoholičarima. Kombinacija oba faktora, pojačava kancerogeni efekat. Efekti alkohola mogu biti modulisani usled postojanja polimorfizama u genima koji kodiraju enzime uključene u metabolizam etanola. Naime, prethodni rezultati naše istraživačke grupe su pokazali da je izvesni polimorfizam u genu za alkoholnu dehidrogenazu (ADHC1 gen), uključenom u konverziju alkohola do acetaldehida, povezan sa povećanim rizikom za razvoj oralnog karcinoma, nezavisno od unosa alkohola (Brocic i sar., 2011). Ovom studijom smo pokazali postojanje veze između unosa alkohola i CYP27B1 rs4646536 polimorfizma. Mutirana i heterozigotna forma CYP27B1 je bila zastupljenija među pacijentima koji nisu ili su umereno unosili alkohol u odnosu na pacijente koji su unosili velike količine alkohola. Studija koja je uključila preko 6000 učesnika, pokazala je da su genetičke varijante u CYP27B1 genu asocirane sa količinom glavne cirkulišuće forme vitamina D, 25(OH) $\mathrm{D}_{3}$ (Berry i Hypponen, 2011). Genetički uticaj na status vitamina D je kompleksan. Možemo pretpostaviti da nealkoholičari i/ili bivši alkoholičari, nosioci određenih genotipskih varijanti CYP27B1 gena, u slučaju proučavanog polimorfizma mutiranog i/ili heterozigotnog genotipa, razvijaju OSCC usled snižene mogućnosti za konverziju $25(\mathrm{OH}) \mathrm{D}_{3} \mathrm{u}$ metabolički aktivnu formu, kalcitriol. Snižena enzimska aktivnost $1 \alpha$-hidroksilaze, kao posledica starenja ili nekih drugih faktora kao što je nedostatak vitamina D u ishrani (Riggs, 2002), a posebno niskog nivoa $25(\mathrm{OH}) \mathrm{D}_{3}$, može predstavljati faktor rizika za razvoj različitih kancera (Li i sar., 2007). Ustanovljena snižena aktivnost 1 $\alpha$-hidroksilaze i snižena ekspresija CYP27B1 u ćelijskim linijama kancera prostate i dojke (Colston i sar., 2006) u poređenju sa ćelijama normalnog tkiva (Hsu i sar., 2001; Lou i sar., 2004) sugeriše da ove ćelije praktično mogu snižavati ili čak izgubiti mogućnost konverzije kalcidiola do kalcitriola na lokalnom nivou i postati nesenzitivne na kalcitriol, što dovodi do neoplastične transformacije ćelije. Postoji mogućnost da polimorfizam rs4646536 u CYP27B1 genu ima funkcionalni efekat ili da je u vezanoj neravnoteži sa drugim polimorfizmima, što rezultuje smanjenom aktivnošću $1 \alpha$-hidroksilaze, što ostaje da se ispita narednim istraživanjima u našoj studijskoj grupi.

Sa starenjem, aktivnost $1 \alpha$-hidroksilaze se smanjuje, dok se aktivnost 24-hidroksilaze povećava (Lou i sar., 2004). Takođe, uočena hipermetilacija 
promotora CYP27B1 gena u MDA-MB-231 ćelijskim linijama kancera dojke i u tumorskom tkivu dojke, rezultuje transkripcionom inaktivacijom CYP27B1 gena in vivo (Shi i sar., 2002). Fiziološke koncentracije $25(\mathrm{OH}) \mathrm{D}_{3}(100 \mathrm{nM})$ stimulišu ekspresiju $1 \alpha$-hidroksilaze, dok $1,25 \alpha(\mathrm{OH})_{2} \mathrm{D}_{3}$ ne utiče na ekspresiju CYP27B1 (Lou i sar., 2004).

\subsection{CYP24A1 polimorfizam}

CYP24A1 gen kodora za enzim 24-hidroksilazu koji ima ulogu u degradaciji kalcitriola. Pretpostavlja se da izvesni polimorfizmi u ovom genu mogu da modifikuju aktivnost enzima. Međutim, epidemiološka istraživanja polimorfnih varijanti u CYP24A1 genu su malobrojna i ograničena. Za mali broj do sada proučavanih SNP-ova nije uvrđeno postojanje asocijacije sa kancerom prostate i postmenopauzalnim kancerom dojke kod Kavkazijanaca (Roff i Taylor Wilson, 2008). Kada je reč o rs2296241 polimorfizmu u CYP24A1 genu, ne postoje podaci niti ispitivanja o funkcionalnosti ovog SNP-a. U slučaju naše studijske grupe, zabeleženo je postojanje razlike u frekvenci genotipova rs2296241 polimorfizma CYP24A1 gena između uzoraka i kontrola ( $\mathrm{p}=0.025)$. Ovakvo zapažanje dovodi $\mathrm{u}$ opravdanu sumnju potencijalno postojanje veze analiziranog polimorfizma i nastanka oralnog karcinoma. Proučavani polimorfizam nije bio u vezi sa kliničko patološkim odlikama oralnog karcinoma. Rezultati ove studije pokazuju da je heterozigotna genetička varijanta rs2296241 polimorfizma u CYP24A1 genu značajno asocirana sa smanjenim rizikom za razvoj oralnog karcinoma u našoj proučavanoj populaciji. Nakon kombinovane analize sa potencijalnim kofaktorima, uočeno je da heterozigotni genotip, u poređenju sa divljom formom, ima 0.281 puta smanjen rizik za razvoj oralnog karcinoma. Prethodnim studijama je zabeleženo odsustvo asocijacije između CYP24A1 rs2296241 polimorfizma i rizika za nastanak karcinoma dojke (Dorjgochoo i sar., 2011; McCullough i sar., 2007) i karcinoma prostate (Holick i sar., 2007), ali je uočena veza ovog polimorfizma sa smanjenim rizikom smrtnosti u slučaju karcinoma prostate (Holt i sar., 2010). Tačan mehanizam kojim ova genetička varijanta utiče na smanjenje rizika za razvoj 
OSCC-a je nepoznata. Stoga bi se moglo pretpostaviti da analizirani polimorfizam ima funkcionalni efekat ili da može uticati na nivo ekspresije CYP24A1 gena. Ranijim istraživanjima je zabeležena viša ekspresija CYP24A1 gena u slučaju tumorskog tkiva ezofagusa u poređenju sa normalnim tkivom (Mimori i sar., 2004), kao i ćelijskim linijama kancera tireoidee koje su bile rezistentne na tretman kalcitriolom (Sharma i sar., 2010). Povišena ekspresija CYP24A1 gena je bila zabeležena tokom tumorske progresije u slučaju kancera pluća, kolona i jajnika (Anderson i sar., 2006), prostate i dojke (Chung i sar., 2007), što ukazuje na moguću rezistenciju ovih tumorskih tipova na tretman kalcitriolom. Nivo ekspresije CYP24A1 gena je bio povećan čak 7000 puta u prisustvu metabolički aktivne forme vitamina D u nekoliko ćelijskih linija melanoma, praćenom značajnom inhibicijom rasta (Alimirah i sar., 2011). Nasuprot tome, nivo iRNK CYP24A1 je bio 100 puta manji u drugim ćelijama melanoma koje nisu bile izložene antikancerogenom efektu kalcitriola (Alimirah i sar., 2011). Pored toga, dublja invazija tumora, povećana incidenca metastaziranja kao i stopa ukupnog preživljavanja je bila značajno viša u slučaju niže ekspresije CYP24A1 i više ekspresije VDR gena (Mimori i sar., 2004). Međutim, prethodno navedene studije nisu razmatrale povezanost nivoa ekspresije CYP24A1 gena sa polimorfizmom rs2296241, te se ostavlja pitanje da li se uočene promene u nivou ekspresije mogu dovesti u vezu sa ovim polimorfizmom i na koji način. Pokazano je da nekoliko novoidentifikovanih SNP-ova u promotorskom regionu egzona 1 CYP24A1 gena ima funkcionalni efekat na vezivanje VDRE i transaktivaciju in vitro kao $\mathrm{i}$ izmenjenu ekspresiju CYP24A1 gena in vivo (Holt i sar., 2010; Roff i Taylor Wilson, 2008). Uzimajući ovaj podatak u obzir, primećena asocijacija u našoj studiji može biti rezultat vezanosti polimorfizma rs2296241 za susedni promotorski region gde su identifikovani funkcionalni SNP-ovi.

$S$ obzirom na značajnu ulogu epigenetičkih mehanizama u procesu kancerogeneze, bitno je spomenuti da bi se i epigenetičke modifikacije trebale uzeti u razmatranje prilikom tumačenja dobijenih rezultata. Naime, nedavnim istraživanjima je pokazano da hipermetilacija i histonska modifikacija promotora CYP24A1 utišava ekspresiju CYP24A1 gena (Luo i sar., 2010). Metilacioni status promotora CYP24A1 gena se razlikuje u endotelnim ćelijama izolovanim iz tumora 
i netumorskog tkiva kod miša (Deeb i sar., 2011). Uočeno je da kalcitriol ima značajan antiproliferacioni efekat na endotelne ćelije izolovane iz tumorskog tkiva u poređenju sa endotelnim ćelijama izolovanim iz normalnog zdravog tkiva. Mehanizam koji je odgovoran za različitu senzitivnost na tretman kalcitriolom je upravo epigenetičko utišavanje CYP24A1 gena u tumorskim endotelijalnim ćelijama (Chung i sar., 2007). U prilog tome govore podaci da je nivo metilovanosti promotora bio 2-17 puta povećan u endotelu tumora prostate u poređenju sa benignim endotelom (Deeb i sar., 2011). Bilo bi značajno proveriti nivo metilovanosti promotora CYP24A1 gena i postojanje veze sa proučavanim polimorfizmom rs2296241 u našoj studijskoj grupi u predstojećem periodu. Skorašnji rezultati ukazuju da je mikro RNK: miR-125b uključena u regulaciju genske ekspresije tako što snižava ekspresiju VDR (Mohri i sar., 2009), a povećava ekspresiju CYP24A1 gena u tumorskim ćelijama (Komagata i sar., 2009). Dakle, povišena ekspresija miR-125b u ćelijama kancera će inhibirati efekat kalcitriola snižavanjem VDR i povećanjem CYP24A1 ekspresije. Iz prethodno navedenog, jasno je da regulaciju genske ekspresije CYP24A1 gena treba sagledati iz više aspekata, razmatrajući metilacioni status promotora kao negativni oblik regulacije, ali i nivo ekspresije miR-125b, koja predstavlja pozitivni vid regulacije. Istovremeno uključivanje polimorfnih varijanti CYP24A1 gena u razmatranje, a posebno rs2296241 proučavane ovom doktorskom disertacijom, u vezi sa epigenetičkim mehanizmima regulacije ekspresije CYP24A1 gena bi dalo dublji uvid za tumačenje dobijenih rezultata.

Rezultati naše studije ukazuju da analizirani polimorfizam u CYP24A1 genu nije asociran sa ukupnim preživljavanjem ( $\mathrm{p}=0.108)$. Ipak, stratifikaciona analiza prema stadijumu bolesti i nodalnom statusu je pokazala da heterozigoti imaju značajno lošije preživljavanje u odnosu na wt genotip u uznapredovalom stadijumu bolesti ( $p=0.021$ ) i podgrupi sa pozitivnim nodalnim statusom ( $p=0.016)$. Moglo bi se pretpostaviti da heterozigotna forma proučavanog polimorfizma ima uticaj na povećanje ekspresije CYP24A1 gena, što bi posledično rezultovalo lošijim preživljavanjem. Utvrđeno je da je nivo ekspresije CYP24A1 značajno viši u tumorskim ćelijama pluća u odnosu na normalne ćelije, što je bilo u vezi sa lošijim preživljavanjem pacijenata od adenokarcinoma pluća, ali nezavisno od tumorskog 
stadijuma (Chen i sar., 2011). Dodatno, primećena je značajna korelacija između visokog nivoa ekspresije CYP24A1 i loše diferenciranosti tumora (Chen i sar., 2011), kao i lošijeg preživljavanja u slučaju karcinoma ezofagusa (Mimori i sar., 2004). Jasna je pretpostavka da je CYP24A1 uključen u proces kancerogeneze, verovatno inhibiranjem antikancerogenog dejstva vitamina D. Prema nekim pretpostavkama, povišena ekspresija gena može biti u vezi sa genskom amplifikacijom, koja je potvrđena u slučaju karcinoma glave i vrata (Lin i sar., 2006), ali se smatra da to nije jedini odgovorni mehanizam za povećanu ekspresiju CYP24A1 gena (Chen i sar., 2011). Takođe, moguće je da je uočeno lošije preživljavanje heterozigota u uznaredovalom stadijumu tumora i prisustvu limfnih metastaza $u$ vezi sa globalnom hipometilacijom koja je odlika procesa kancerogeneze i koja može dovesti do aktivacije onkogena (Šupić i Magić, 2009). S obzirom da se CYP24A1 smatra ozbiljnim kandidatom za onkogena (Chung i sar., 2007; Mimori i sar., 2004; Albertson i sar., 2000), postoji verovatnoća da sa tumorskom progresijom i globalnom hipometilacijom dolazi do aktivacije CYP24A1 gena, povišenja ekspresije i posledično izbegavanja antikancerogenog dejstva kalcitriola, što na kraju rezultuje lošijim preživljavanjem.

Poznavanje molekularnih i funkcionalnih posledica postojanja VDR, CYP27B1 i CYP24A1 polimorfizama je krucijalno za potpuno razumevanje njihovog značaja i potencijalne kliničke primene (Uitterlinden i sar., 2004). Našem istraživanju nedostaju podaci o ekspresiji ova tri gena, što bi bilo od posebnog značaja za utvrđivanje postojanja potencijalne veze između analiziranih polimorfizama, a posebno FokI polimorfizma i nivoa ekspresije VDR gena, odnosno rs2296241 polimorfizma i CYP24A1 gena, kao i za utvrđivanje postojanja asocijacije između ekspresije i preživljavanja pacijenata. Skorašnje istraživanje ukazuje da je visoka ekspresija VDR-a povezana sa manje uznapredovalim stadijumom tumora i smanjenim rizikom letalnosti od kancera prostate (Hendrickson i sar., 2011). Interesantno je da je u istoj studiji pokazano da nivo VDR ekspresije nije bio $u$ vezi ni sa nivoom vitamina $D$ u serumu, niti sa proučavanim FokI i BsmI VDR polimorfizmima (Hendrickson i sar., 2011). 
Povišena ekspresija VDR gena je zabeležena u tumoru pluća u odnosu na normalno tkivo (Zhou i sar., 2006). VDR aktivnost može biti pojačana $\beta$-kateninom, koji čini ćelije tumorske mase više adherentnim jednu za drugu i smanjuje verovatnoću metastaziranja velikog broja malignih ćelija u limfotok ili krvotok (Palmer i sar., 2001; Zhou i sar., 2006). Analiza ekspresije VDR gena imunohistohemijskim metodama kod pacijenata sa dijagnostikovanim krupnoćelijskim karcinomom pluća je pokazala da je viši nivo ekspresije jedarnog VDR-a nezavisno asociran sa boljim preživljavanjem pacijenata. Veza između ekspresije citoplazmatskog VDR-a i preživljavanja kod pacijenata u istoj studiji nije pronađena. Ovim istraživanjem je takođe pokazano da se nivo VDR-a može koristiti kao prognostički marker $\mathrm{u}$ slučaju krupnoćelijskog karcinoma pluća (Srinivasan i sar., 2011). Međutim ovom studijom nije ispitivano postojanje veze polimorfizama u VDR genu i preživljavanja pacijenata.

Studije humanih karcinoma $\mathrm{u}$ kojima je merena VDR koncentracija imunoradiometrijskim esejima su pokazali da dolazi do promene broja VDR-a kada ćelija podleže malignoj transformaciji, što sugeriše na korišćenje merenja količine VDR-a kao prognostičkog markera (Srinivasan i sar., 2011). Prema rezultatima dobijenih jednim istraživanjem, uočeno je da preživljavanje pacijenata, obolelih od krupnoćelijskog karcinoma pluća, zavisi i od sezone u kom je vršen hirurški zahvat i visokog unosa vitamina D (Turna i sar., 2012). Stoga sezona kada je izvršena operacija, kao i kombinovani genotip može služiti kao nezavisni prognostički faktor u slučaju krupnoćelijskog karcinoma pluća (Turna i sar., 2012).

Što se tiče analize promenljivih relevantinih za ukupno preživljavanje pacijenata, univarijantnom Cox regresionom analizom smo pokazali da pored FokI polimorfizma, alkohol, stadijum bolesti, nodalni status i veličina tumora mogu da se koriste kao prognostički faktori. Ove varijable su testirane zajedno multivarijantnom regresionom analizom, pri čemu su iz analize isključeni nodalni status i veličina tumora, koji svakako predstavljaju elemente koji određuju stadijum bolesti i kao takvi bi mogli da zamaskiraju efekat stadijuma. Pokazali smo da se stadijum bolesti kao i FokI polimorfizam mogu koristiti kao nezavisni prognostički faktori za oralni karcinom. Statistička značajnost za alkohol je izgubljena, što govori da, iako značajan faktor rizika za razvoj oralnog karcinoma, 
unos alkohola nije dovoljan pokazatelj na osnovu kog se može predvideti prognoza samog toka bolesti. Kao što je bilo očekivano, potvrdili smo da se stadijum bolesti može koristiti kao nezavisni prognostički faktor.

Poređenje naših rezultata za analizirane polimorfizme u VDR, CYP27B1 i CYP24A1 genima i drugih istraživanja, ukazuje na visok stepen nekonzistentnosti među studijama. Tako dobijeni različiti rezultati bi se mogli objasniti razlikama u učestalosti alela odnosno genotipova između različitih etničkih grupa (Lurie i sar., 2007, Bid i sar., 2005), tkivnoj specifičnosti, veličini uzorka i odabira pacijenata za studiju, ali i izloženosti faktorima spoljne sredine i ishrane. Analiziranjem podataka dostupnih u SNP bazi (www.ncbi.nlm.nih.gov/SNP) očigledno je postojanje razlike u učestalostima alela proučavanih polimorfizama VDR gena između Kavkazoidne, Azijske i Afričke grupe. Pretpostavlja se da relativno stari polimorfizmi imaju malu varijaciju između različitih etničkih grupa, dok veće razlike mogu postojati u slučaju relativno novih polimorfizama (Uitterlinden i sar., 2004). Pojedinačni funkcionalni polimorfizmi mogu imati iste funkcionalne efekte u različitim etničkim grupama zato što je fiziološka uloga vitamima D ista u slučaju svih etničkih grupa. Ovo predstavlja osnovu i za interpretaciju epidemioloških studija gde je učestalost alela između etničkih grupa u asocijaciji sa različitim incidencama bolesti/fenotipova u datim proučavanim grupama.

Svakako, uključivanje podataka o faktorima spoljašnje sredine, nivoa cirkulišuće forme vitamina D u serumu i ishrane bi mogao dati kompletniji uvid za uočene razlike dobijene različitim istraživanjima, uključujući i naše istraživanje. Visok stepen insuficijencije vitamina D je zabeležen kod pacijenata sa karcinomom glave i vrata na području Finske (Orell-Kotikangas i sar., 2012). Period bez pojave bolesti, kao i ukupno vreme preživljavanja su bili značajno asocirani sa nivoom $25(\mathrm{OH}) \mathrm{D}_{3}$, gde je viši nivo cirkulišuće forme bio povezan sa boljim preživljavanjem (Srinivasan i sar., 2011). Prema rezultatima jedne istraživačke grupe, nivo vitamina D je bio povezan sa boljim preživljavanjem pacijenata sa ranim stadijomom krupnoćelijskog karcinoma pluća (Zhou i sar., 2006), dok u slučaju uznapredovalog stadijuma nije zabeleženo postojanje veze između preživljavanja i nivoa vitamina D (Heist i sar., 2008). Iz navedenih podataka se može zaključiti da 
nivo vitamina D ima izvesni uticaj na incidencu i smrtnost, ne samo karcinoma glave i vrata (Gugatschka i sar., 2011), već i drugih karcinoma.

Nivo vitamina D je takođe genetički determinisan u prilog čemu govore podaci o postojanju asocijacije između Afričkog porekla i nižeg nivoa vitamina D (Field i Newton-Bishop, 2011). GWAS projektom su identifikovani SNP-ovi u blizini gena koji kodiraju za jedinjenja uključena u sintezu holesterola, hidroksilaciju i transport vitamina $D$, koje takođe predstavljaju determinante nivoa vitamina D (Field i Newton-Bishop, 2011). Takođe, poznato je da je nivo vitamina D povezan $\mathrm{i}$ sa tipom kože, indeksom gojaznosti, ishranom, izlaganjem Suncu i konačno genetičkim varijantama (Field i Newton-Bishop, 2011). Poslednjih nekoliko godina je sve veći broj dokaza koji ukazuju da su varijacije u nivou vitamina D i polimorfizmi u genu za receptor za vitamin D asocirani sa izmenjenim rizikom nastanka različitih maligniteta. U nedavnom istraživanju sprovedenom u populaciji Kineza, uočeno je da je visok nivo $25(\mathrm{OH}) \mathrm{D}_{3}$ u plazmi povezan sa lošijim preživljavanjem pacijenata od krupnoćelijskog karcinoma pluća i rizik od smrti je bio značajno povećan u odnosu na pacijente sa nižim nivoom $25(\mathrm{OH}) \mathrm{D}_{3}$ u plazmi (Liu i sar., 2011). U istoj studiji, TaqI i BsmI su bili asocirani sa preživljavanjem, pri čemu je BsmI identifikovan kao nezavisan prognostički faktor za preživljavanje u slučaju krupnoćelijskog karcinoma pluća (Liu i sar., 2011). Za razliku od drugih populacija, nivo vitamina D u plazmi i navedeni VDR SNP-ovi se mogu koristiti kao prognostički biomarkeri za krupnoćelijski karcinom u Kineskoj populaciji. Uočene etničke razlike u učestalosti alela i genotipova mogu biti delimično odgovorne za različite rezultate među studijama. Rezultati su vrlo kontroverzni ne samo po pitanju nivoa vitamina D, nego i uloge VDR polimorfizama. VDR gen je visoko polimorfan i trenutno se ne zna tačno koliko polimorfizama je vezano za bolesti niti koliki je nivo doprinosa svakog od njih. U našoj ispitivanoj studijskoj grupi, podaci o ishrani i relativnom unosu vitamina $D$, kao i nivou vitmina $D$ u serumu nedostaju, a što bi možda moglo da da kompletniji uvid u moguće postojanje veze između unosa vitamina D ishranom, nivoa $25(\mathrm{OH}) \mathrm{D}_{3}$ u serumu, polimorfizama VDR gena i rizika za razvoj oralnog karcinoma i preživljavanja. Uzimajući ove podatke u obzir, može se reći da vitamin D ima očigledno značajnu protektivnu ulogu u 
kancerogenezi. Sa tim u vezi i analozi vitamina D bi mogli poslužiti kao antikancerogeni agensi.

Incidence različitih tipova karcinoma se razlikuju između rasa/etničkih grupa i dublje razumevanje genetičkih i sredinskih uzroka ovih razlika predstvalja istovremeno i naučnu i medicinsku potrebu. Genetičke studije asocijacije daju značajne informacije o etiologiji različitih karcinoma. Etiologija humanih karcinoma je izuzetno kompleksna tematika. Samo za mali broj karcinoma, kao što je karcinom pluća ili cerviksa je poznat faktor rizika koji je najodgovorniji za incidencu konkretnog karcinoma u populaciji (Haiman i Stram, 2010). Za većinu drugih karcinoma, naše poznavanje sredinskih faktora, genetičke predispozicije kao i međusobni odnos između ova dva etiološka faktora je daleko od potpunog poznavanja i razumevanja. Uočena variranja u incidenci i mortalitetu karcinoma unutar i između populacija se smatraju posledicom različite zastupljenosti genetičkih i sredinskih faktora rizika (Haiman i Stram, 2010).

Smatra se da genetičke varijante mogu imati različite efekte u različitim populacijama zbog nepoznatih ili neizmerenih sredinskih faktora rizika, koji mogu modifikovati penetrantnost određene genetičke varijante (Uitterlinden i sar., 2004). Studije koje imaju za cilj otkrivanje faktora rizika za nastanak različitih tipova karcinoma se oslanjaju na samoizjašnjavanje po pitanju rasne i etničke pripadnosti, što relativizuje tumačenje rezultata. Očekuje se da će u bliskoj budućnosti smanjenje zdravstvenih razlika zahtevati detaljnu procenu bioloških i nebioloških komponenata rase/etniciteta koji se značajno prepliću (Uitterlinden i sar., 2004).

Kao što se može zapaziti iz prethodno iznetih rezultata dobijenih našom studijom i poređenjem sa rezultatima dobijenih drugim istraživanjima, rezultati između različitih studija su nekonzistentni po pitanju povezanosti polimorfizama VDR gena i gena uključenih u metabolizam vitamina $D$ sa rizikom za razvoj karcinoma glave i vrata, uključujući i oralni karcinom. Uočene razlike verovatno odražavaju heterogenost karcinoma glave i vrata kao i oralnih karcinoma $\mathrm{u}$ pogledu histologije i kliničkih karakteristika, sa različitim etiologijama i faktorima rizika (Forastiere i sar., 2001). Pored toga, različiti rezultati u poređenju sa našim nalazima za proučavane polimorfizme se mogu dovesti u vezu sa etničkom i 
rasnom varijabilnošću između populacija ili čak i regionalnih razlika u količini vitamina D koji se unosi ishranom, što može biti važan faktor za razvoj oralnog karcinoma. Pored toga različiti stepen izloženosti faktorima spoljašnje sredine, npr. Sunčevom zračenju, predstavljaju bitne faktore koji mogu usloviti dobijanje oprečnih rezultata između studija. Iz svega navedenog u diskusiji, jasno je da za dobijanje potpune i kompletne slike uloge i značaja polimorfizama nukleotidne sekvence u genima bitnim za funkcionisanje i metabolizam vitamina D u vezi sa oralnim karcinomom, pored genotipova proučavanih polimorfizama neophodno je $\mathrm{u}$ razmatranje uzeti $\mathrm{i}$ analize ekspresije proučavanih gena, epigenetičke mehanizme, povezanosti polimorfizama sa nivoom cirkulišuće forme vitamina $\mathrm{D} u$ serumu, faktorima ishrane i izloženošću faktorima spoljašnje sredine (npr. izloženost Sunčevom zračenju). Dalje proširivanje ove studije bi trebalo da uključi navedene faktore koji bi dodatno mogli da potvrde i razjasne do sada dobijene rezultate u ovoj studiji. 
6. ZAKLJUČCI 
Na osnovu dobijenih rezultata ove doktorske disertacije, izvedeni su sledeći zaključci:

$>\quad$ Između grupe pacijenata sa dijagnostikovanim oralnim karcinomom i kontrolne grupe odgovarajuće polne i starosne distribucije je uočena razlika u distribuciji genotipova EcoRV, ApaI i TaqI polimorfizama VDR gena, kao i polimorfizma u CYP24A1 genu. Ovakav nalaz bi mogao da ukazuje na potencijalnu ulogu navedenih polimorfizama u podložnosti razvijanja oralnog karcinoma.

Uočena je statistički značajna razlika u distribuciji alela u slučaju VDR EcoRV i ApaI polimorfizama, kao i polimorfizma CYP24A1 gena.

> Stratifikovana analiza u odnosu na pol je pokazala postojanje značajne razlike u distribuciji VDR EcoRV i BsmI polimorfizma među pripadnicima muškog pola grupe obolelih u odnosu na pripadnike istog pola kontrolne grupe, kao i u slučaju proučavanog polimorfizma CYP24A1 gena. Razlika u distribuciji datih polimorfizama nije detektovana među pripadnicama ženskog pola između grupe obolelih i kontrolne grupe.

> Statistička analiza polimorfizama i etioloških faktora je ukazala na postojanje asocijacije između VDR TaqI i BsmI polimorfizama i CYP27B1 polimorfizma i pola pacijenata sa dijagnostikovanim oralnim karcinomom. Uočena je veza između TaqI polimorfizma i pušenja i CYP27B1 analiziranog polimorfizma i konzumacije alkohola.

> Zapažena asocijacija ApaI polimorfizma u VDR genu i godina pacijenata verovatno ne predstavlja samo rezultat procesa starenja, već dužeg perioda izloženosti kancerogenim jedinjenjima prisutnim u duvanu, alkoholu i generalno u spoljašnjoj sredini. 
$>$ Našom studijom nije utvrđeno postojanje asocijacije analiziranih polimorfizama i kliničko patoloških odlika oralnog karcinoma, osim u slučaju identifikovane značajne veze između TaqI polimorfizma VDR gena i pojave recidiva bolesti.

$>\quad$ Pokazano je da su mutirane varijante VDR polimorfizama EcoRV i ApaI značajno asocirani sa sniženim rizikom za razvoj oralnog karcinoma, dok su homozigotna mutirana i heterozigotna varijanta BsmI polimorfizma povezane sa povišenim rizikom sa nastanak oralnog karcinoma. Nakon udružene analize sa godinama, polom, pušenjem i konzumacijom alkohola, ove statističke značajnosti su izgubljene.

> Polimorfizam u CYP24A1 genu je značajno asociran sa sniženim rizikom za razvoj oralnog karcinoma, što je najverovatnije rezultat njegovog funkcionalnog efekta ili neravnoteže vezanosti sa drugim polimorfizmima unutar CYP24A1 gena ili čak sa polimorfizmima blisko lociranih susednih gena.

$>\quad$ Divlja (wt) homozigotna forma proučavanog polimorfizma FokI VDR gena je povezana sa lošijim preživljavanjem pacijenata sa oralnim karcinomom u odnosu na heterozigotnu i homozigotnu mutiranu varijantu zajedno. Isti trend preživljavanja je zapažen i u slučaju stratifikacije prema nodalnom statusu i uznapredovalom stadijumu bolesti. Zapažena veza je najverovatnije posledica postojanja funkcionalnog efekta FokI polimorfizma, s obzirom da je poznato da mutirana varijanta FokI polimorfizma rezultuje nastajanjem VDR receptora kraćeg za tri amino kiseline u odnosu na $w t$ formu, ali većeg transaktivacijskog kapaciteta.

> Polimorfizam FokI VDR gena se može koristiti kao samostalni prognostički indikator u slučaju oralnog karcinoma, što je potvrđeno i za stadijum bolesti, ali ne i za konzumiranje alkohola. 
> Identifikovani haplotipovi BsmI-ApaI-TaqI tri lokusnog sistema nisu u asocijaciji sa rizikom za nastanak oralnog karcinoma, niti preživljavanjem pacijenata.

Sumirano, analiza polimorfizama gena uključenih $u$ funkcionisanje $i$ metabolizam vitamina D može dati važne informacije o razvoju i progresiji oralnog karcinoma. VDR FokI polimorfizam može biti razmatran kao potencijalni molekularni marker za preživljavanje pacijenata sa oralnim karcinomom, to jest ima ulogu nezavisnog prognostičkog indikatora. Pored toga polimorfizam rs2296241 CYP24A1 gena je asociran sa sniženim rizikom za razvoj oralnog karcinoma, što bi moglo ukazati na potencijalno korišćenje datog polimorfizma u prediktivne svrhe.

Etiologija oralnog karcinoma je vrlo kompleksna i pored poznatih faktora rizika uključuje interakciju genotipa i faktora spoljašnje sredine. Poznavanje genetičke varijante gena koji su asocirani sa rizikom nastanka oralnog karcinoma bi u budućnosti moglo da omogući uvođenje koncepta personalizovane medicine, u smislu davanja individualnih saveta i/ili terapije.

Dalje studije koje će biti usmerene na dodatna ispitivanja, obuhvatiće analizu većeg broja polimorfizama i haplotipskih blokova, unos vitamina D ishranom, nivo vitamina D u serumu, kao i nivoa ekspresije ključnih gena, dodatno će doprineti rasvetljavanju postojećih rezultata i zaključaka prezentovanih u ovoj doktorskoj disertaciji. 
7. LITERATURA 


\section{A}

Abo-Hanger E, Gawish A, El-Guinday N, Azzam O. Vitamin D receptor gene polymorphism and risk of oral squamous cell carcinoma. J Appl Sci Res 2008; 4: 929-938.

Ahn J, Albanes D, Berndt S, Peters U, Chatterjee N, Freedman N, Abnet C, Huang W, Kibel A, Crawford D, Weinstein S, Chanock S, Schatzkin A, Hayes R. Vitamin Drelated genes, serum vitamin D concentrations and prostate cancer risk. Carcinogen 2009; 30: 769-776.

Albertson G, Ylstra B, Segraves R, Collins C, Dairkee H, Kowbel D, Kuo L, Gray W, Pinkel D. Quantitative mapping of amplicon structure by array CGH identifies CYP24 as a candidate oncogene. Nat Rev 2000; 25: 144-146.

Ali V, Vaidya V. Vitamin D and cancer. J Cancer Res Ther 2008; 3: 225-230.

Alimirah F, Peng X, Murillo G, Mehta R. Functional significance of vitamin D receptor FokI polymorphism in human breast cancer cells. Plos One 2011; 6: e16024.

Amano Y, Komiyama K, Makishima M. Vitamin D and periodontal disease. J Oral Sci 2009; 51: 11-20.

Anderson M, Nakane M, Ruan X, Kroeger P, Wu-Wong R. Expression of VDR and CYP24A1 mRNA in human tumors. Cancer Chemother Pharmacol 2006; 57: 234240.

Aung T, Chandina S, D'Silva K, Dimitrov N. The role of vitamin D in breast cancer. Oncol Rev 2009; 3: 19-25. 


\section{B}

Bader J. The relative power of SNPs and haplotype as genetic markers for association tests. Pharmacogenomics 2001; 2: 11-24.

Bai Y, Lu H, Hong D, Lin C, Yu Z, Chen B. Vitamin D receptor gene polymorphisms and colorectal cancer risk: A systematic meta-analysis. World J Gastroenterol 2012; 18: 1672-1679.

Bailey R, Cooper J, Zeitels L, Smyth D, Yang J, Walker N, Hypponen E, Dunger D, Ramos-Lopez E, Badenhoop K, Nejentsev S, Todd J. Association of the vitamin D metabolism gene CYP27B1 with type 1 diabetes. Diabetes 2007; 56: 2616-2621.

Bao B, Yao J, Lee Y. $1 \alpha, 25$-dihydroxyvitamin $\mathrm{D}_{3}$ supress interleukin-8-mediated prostate cancer cell angiogenesis. Carcinogen 2006; 27: 1883-1893.

Barrett J, Fry B, Maller J, Daly M. Haploview: analysis and visualization of LD and haplotype maps. Bioinformatics 2005; 21: 263-265.

Barroso E, Fernandez L, Milne R, Pita G, Sendagorta E, Floristan U, Feito M, Aviles J, Martin-Gonzales M, Arias J, Zamora P, Blanco M, Lazaro P, Benitez J, Ribas G. Genetic analysis of the vitamin D receptor gene in two epithelial cancers: melanoma and breast cancer case-control studies. BMC Cancer 2008; 8: 385393.

Bektas-Kayhan K, Unur M, Yaylim-Eraltan I, Ergen HA, Toptas B, Hafiz G, Isbir T. Association of vitamin D receptor TaqI polymorphism and susceptibility to oral squamous cell carcinoma. In Vivo 2010; 24: 755-759.

Berry D, Hypponen E. Determinants of vitamin D status: focus on genetic variations. Curr Opin Nephrol Hypertens 2011; 20:331-336. 
Beuten J, Gelfond J, Franke J, Weldon K, Crandall A, Johnson-Pais T, Thompson I, Leach R. Single and multigenic analysis of the association between variants in 12 steroid hormone metabolism genes and risk of prostate cancer. Cancer Epidemiol Biomarkers Prev 2009; 18: 1869-1880.

Bid H, Mishara D, Mittal R. Vitamin D receptor (VDR) gene (FokI, TaqI \& ApaI) polymorphisms in healthy individuals from North Indian population. Asian Pacific J Cancer Prev 2005; 6:147-152.

Bikle D. Nonclassic actions of vitamin D. J Clin Endocrinol Metab 2009; 94: 26-34.

Bikle D. What is new in vitamin D: 2006-2007. Curr Opin Rheumatol 2007, 19: 383388.

Bodiwala D, Luscombe C, French M, Liu S, Saxby M, Jones P, Fryer A, Strange R. Polymorphisms in the vitamin $\mathrm{D}$ receptor gene, ultraviolet radiation and susceptibility to prostate cancer. Environ Mol Mutagen 2004; 43:121-127.

Bonilla C, Hooker S, Mason T, Bock C, Kittles R. Prostare cancer susceptibility loci identified on chromosome 12 in African Americans. PLoS One 2011; 6: e16044.

Bos P, Zhang X, Nadal C, Shu W, Gomis R, Nguyen D, Minn A, van de Vijver M, Gerald WL Foekens J, Massagué J. Genes that mediate breast cancer metastasis to the brain. Nature 2009; 459: 1005-1009.

Bouillon R, Carmeliet G, Verlinden L, van Etten E, Verstuyf A, Luderer H, Lieben L, Mathieu C, Demay M. Vitamin D and human health: lessons from vitamin D receptor null mice. Endocrine Rev 2008; 6: 726-776.

Bouillon R, Eelen G, Verlinden L, Mathieu C, Carmeliet G, Verstuyf A. Vitamin D and cancer. J Steroid Biochem Mol Biol 2006; 102: 156-162. 
Broćić M, Šupić G, Zeljić K, Jović N, Kozomara R, Zagorac S, Zlatković M, Magić Z. Genetic polymorphisms of ADHIC and CYP2EI and risk of oral squamous cell carcinoma. Otolaryngo Head Neck Surg 2011; 145: 586-593.

Broćić M. Klinički značaj nivoa ekspresije vaskularnog endotelijalnog faktora rasta kod bolesnika sa planocelularnim karcinomom jezika i poda usta-magistarski rad. 2008.

Burke H. Outcome prediction and the future of the TNM staging system. J Natl Cancer Inst 2004; 96: 1408-1409.

C

Carlberg C, Seuter S. A genomic perspective on vitamin D signaling. Anticancer Res 2009; 29: 3485-3494.

Chen G, Kim S, King A, Zhao L, Simpson R, Christensen P, Wang Z, Thomas D, Giordano T, Lin L, Brenner D, Beer D, Ramnath N. CYP24A1 is an independent prognostic marker of survival in patients with lung adenocarcinoma. Clin Cancer Res 2011; 17: 817-826.

Choi S, Myers J. Molecular pathogenesis of oral squamous cell carcinoma: implications for therapy. J Dent Res 2008; 87: 14-32.

Chung I, Karpf A, Muindi J, Conroy J, Nowak N, Johnson C, Trump D. Epigenetic silencing of CYP24 in tumor-derived endothelial cells contributes to selective growth inhibition by calcitriol. J Biol Chem 2007; 282: 8704-8714.

Cicek M, Liu X, Schumacher F, Casey G, Witte J. Vitamin D receptor genotypes/haplotypes and prostate cancer risk. Cancer Epidemiol Biomarkers Prev 2006; 15: 2549-2552. 
Colin E, Weel A, Uitterlinden A, Buurman C, Birkenhager J, Pols H, van Leeuwen J. Consequences of vitamin $\mathrm{D}$ receptor gene polymorphisms for growth inhibition of cultured human peripheral blood mononuclear cells by 1,25dihydroxyvitamin D3. Clin Endocrinol 2000; 52: 211-216.

Collins A. Allelic association: Linkage Disequilibrium structure and gene mapping. Mol Biotechnol 2008; 41: 83-89.

Colston K, Lowe L, Mansi J, Campbell M. Vitamin D status and breast cancer risk. Anticancer Res 2006; 26: 2573-2580.

Conway D. Each portion of fruit or vegetable consumed halves the risk of oral cancer. Evid Based Dent 2007; 8: 19-20.

Cross H, Kallay E, Lechner D, Gerdenitsch W, Adlercreutz H, Armbrecht J. Phytoestrogens and vitamin D metabolism: a new concept for the prevention and therapy of colorectal, prostate and mammary carcinomas. J Nutr 2004; 1207S-1212S.

Cross H, Kallay E. Regulation of the colonic vitamin D system for prevention ot tumor progression: an update. Future Oncol 2009; 5: 493-507.

Cui Y, Rohan T. Vitamin D, calcium and breast cancer risk: a review. Cancer Epidemiol Biomarkers Prev 2006; 15: 1427-1437.

D

Davis C, Milner J. Nutrigenomics, vitamin D and cancer prevention. J Nutrigenet Nutrigenomics 2011; 4: 1-11.

Davis C, Milner J. Biomarkers for diet and cancer prevention research: potentials and challenges. Acta Pharmacol Sin 2007; 28: 1262-1273. 
Davis C. Vitamin D and cancer: current dilemmas and future research needs. $A m \mathrm{~J}$ Clin Nutr 2009; 88: 565S-569S.

Deeb K, Luo W, Karpf A, Omilian A, Bshara W, Tian L, Tangrea M, Morrison C, Johnson C, Trump D. Differential vitamin D 24-hydroxylase/CYP24A1 gene promoter methylation in endothelium from benign and malignant human prostate. Epigenetics 2011; 6: 994-1000.

Deeb K, Trump D, Johnson C. Vitamin D signalling pathways in cancer: potential for anticancer therapeutics. Nat Rev 2007; 7: 684-700.

Denzer N, Vogt T, Reichrath J. Vitamin D receptor (VDR) polymorphisms and skin cancer. Dermato-Endocrinology 2011; 3: 205-210.

Dong L, Ulrich C, Hsu L, Duggan D, Benitez D, White E et al. Vitamin D related genes, CYP24A1 and CYP27B1 and colon cancer risk. Cancer Epidemiol Biomarkers Prev 2009; 18: 2540-2548.

Dorjgochoo T, Delahanty R, Lu W, Long J, Cai Q, Zheng Y, Gu K, Gao YT, Zheng W. Common genetic variants in the vitamin D pathway including genome-wide associated variants are not associated with breast cancer risk among Chinese women. Cancer Epidemiol Biomarker Prev 2011; 20: 2313-2316.

Dusso A, Brown A, Slatopolsky E. Vitamin D. Am J Physiol Renal Physiol 2005; 289: F8-F28.

$\mathbf{E}$

Elledge R, Clark G, Chamness G, Osborne C. Tumor biologic factors and breast cancer prognosis among white, Hispanic and black women in the United States. $J$ Natl Cancer Inst 1994; 86: 705-712. 


\section{$\mathbf{F}$}

Fallin D, Schork N. Accuracy of haplotype frequency estimation for biallelic loci, via the expectation-maximization algorithm for unphased diploid genotype data. Am J Hum Genet 2000; 67: 947-959.

Field S, Newton-Bishop J. Melanoma and vitamin D. Mol Oncol 2011; 5: 197-214.

Fischer D, Thome M, Becker S, Cordes T, Diedrich K, Friedrich M, Thill M. Expression of 25-hydroxyvitamin D3-24-hydroxylase in benign and malignant ovarian cell lines and tissue. Anticancer Res 2009; 29: 3635-3640.

Forastiere A, Koch W, Trotti A, Sidransky D. Head and neck cancer. N Engl J Med 2001; 345: 1890-1900.

Frazer K, Murray S, Schor N, Topol E. Human genetic variation and its contribution to complex traits. Nat Rev Genet 2009; 10: 241-251.

G

Gapska P, Scott R, Serrano-Fernandez P, Huzarski T, Byrski T, et al. Vitamin D receptor variants and breast cancer risk in the Polish population. Breast Cancer Res Treat 2009; 115: 629-633.

Garland C, Garland F, Gorham E, Lipkin M, Newmark H, Mohr S, Holick M. The role of vitamin D in cancer prevention. Am J Publish Health 2004; 96: 252-261.

Giovannucci E, Liu Y, RimmE, Hollis B, Fuchs C, Stampfer M, Willett W. Prospective study of predictors of vitamin D status and cancer incidence and mortality in men. J Natl Cancer Inst 2006; 98: 451-459.

Global Cancer: Facts and figures, 2nd Edition. American Cancer Society 2011. 
Gorham E, Garland C, Garland F, Grant W, Mohr S, Lipkin M, Newmark H, Giovnnucci E, Wei M, Holick M. Vitamin D and prevention of colorectal cancer. J Steroid Biochem Mol Biol 2005; 97: 179-194.

Gorham E, Garland C, Garland F. Acid haze air pollution and breast and colon cancer mortality in 20 Canadian cities. Can J Public Health 1989; 80: 96-100.

Gugatschka M, Kiesler K, Obermayer-Pietsch B, Groselj-Strele A, Griesbacher A, Friedrich G. Vitamin D status is associated with disease-free survival and overall survival time in patients with squamous cell carcinoma of the upper aerodigestive tract. Eur Arch Otorhinolaryngol 2011; 268: 1201-1204.

Gunes S, Yucel Bilen C, Kara N, Asci R, Bagci H, Yilmaz AF. Vitamin D receptor gene polymorphisms in patients with urolithiasis. Urol Res 2006; 34: 47-52.

Guy M, Lowe L, Wat-Bretherton D, Mansi J, Peckitt C, Bliss J et al. Vitamin D receptor gene polymorphisms and breast cancer risk. Clin Cancer Res 2004; 10 : 5472-5481.

H

Habuchi T, Suzuki T, Sasaki R, Wang L, Sato K, Satoh S et al. Association of vitamin $D$ receptor with prostate cancer and benign prostatic hyperplasia in a Japanese population. Cancer Res 2000; 60: 305-308.

Hacer Onen I, Ekmekci A, Eroglu M, Konac E, Yesil S, Biri H. Association of genetic polymorphisms in vitamin $\mathrm{D}$ receptor gene and susceptibility to sporadic prostate cancer. Exp Biol Med 2008; 233: 1608-1614.

Haghpanah V, Ghaffari SH, Rahimpour $\mathrm{P}$ et al. Vitamin D receptor gene polymorphisms in patients with thyroid cancer. Gene Ther Mol Biol 2007; 11: 299-304. 
Haiman C, Stram D. Exploring genetic susceptibility to cancer in diverse populations. Curr Opin Genetics Dev 2010; 20: 1-6.

Halsall J, Osborne J, Epstein M, Pringle J, Hutchinson P. The unfavorable effect of the A allele of the vitamin D receptor promoter polymorphism A-1012G has different mechanisms related to susceptibility and outcome of malignant melanoma. Dermato-Endocrinology 2009; 1: 54-57.

Hama T, Norizoe C, Suga H, Mimura T, Kato T, Moriyama H, Urashima M. Prognostic significance of vitamin D receptor polymorphisms in head and neck squamous cell carcinoma. PlosONE 2011; 6: e29634.

Han J, Colditz G, Hunter D. Polymorphisms in the MTHFR and VDR genes and skin cancer risk. Carcinogenesis 2007; 28: 390-397.

Hansen C, Binderup L, Hamberg K, Carlberg C. Vitamin D and cancer: effects of $1,25(\mathrm{OH})_{2} \mathrm{D}_{3}$ and its analogs on growth control and tumorigenesis. Front Biosci 2001; 6: 820-848.

Hawkins G, Cramer S, Zheng S, Isaacs S, Wiley K, Chang B, Bleecker E, Walsh P, Meyers D, Isaacs W, Xu J. Sequence variants in the human 25-hydroxyvitamin $\mathrm{D}_{3}$ 1-a hydroxylase (CYP27B1) gene are not associated with prostate cancer risk. Prostate 2002; 53: 175-178.

Heist RS, Zhou W, Wang Z, Liu G, Neuberg D, Su L et al. Circulating 25Hydroxyvitamin D, VDR polymorphisms and survival in advanced non-small cell lung cancer. J Clin Oncol 2008; 26: 5596-5602.

Hendrickson K, Flavin R, Kasperzyk L, Fiorentino M, Fang F, Lis R, Fiore C, Penney L, Ma J, Kantoff W, Stampfer J, Loda M, Mucci A, Giovannucci E. Vitamin D receptor protein expression in tumor tissue and prostate cancer progression. $J$ Clin Oncol 2011; 29: 2378-2385. 
Herman J, Baylin S. Gene Silencing in Cancer in Association with Promoter Hypermethylation. N Engl J Med 2003; 349: 2042-2054.

Hershberger P, Modzelewski R, Shurin Z, Rueger R, Trump D, Johnson C. 1,25dihydroxycholecalciferol $\left(1,25-\mathrm{D}_{3}\right)$ inhibits the growth of squamous cell carcinoma and down-modulates $\mathrm{p} 21^{\mathrm{Waf} 1 / \mathrm{Cip} 1}$ in vitro and in vivo. Cancer Res 2000; 59: 2644-2649.

Holick C, Stanford J, Kwon E, Ostrander E, Nejentsev S, Peters U. Comprehensive association analysis of the vitamin D pathway genes, VDR, CYP27B1 and CYP24A1 in prostate cancer. Cancer Epidemiol Biomarkers Prev 2007; 16: 1990 1999.

Holt S, Kwon E, Koopmeiners J, Lin D, Feng Z, Ostrander E, Peters U, Stanford J. Vitamin D pathway gene variants and prostate cancer prognosis. Prostate 2010: 70: $1448-1460$.

Holt S, Kwon E, Peters U, Ostrander E, Stanford J. Vitamin D Pathway Gene Variants and Prostate Cancer Risk. Cancer Epidemiol Biomarkers Prev 2009; 18: 19291933.

Hsu J, Feldman D, McNeal J, Peehl D. Reduced 1a-hydroxylase Activity in Human Prostate Cancer Cells Correlates with Decreased Susceptibility to 25Hydroxyvitamin D3-induced Growth Inhibition. Cancer Res 2001; 6: 28522856.

Huang X, Cao Z, Zhang Z, Yang Y, Wang J, Fang D. No association between Vitamin D receptor gene polymorphisms and nasopharyngeal carcinoma in a Chinese Han population. BioSci Trends 2011; 5: 99-103. 
Hughes D, Hlavata I, Soucek P, Pardini B, Naccarati A, Vodickova L, Jenab M, Vodicka P. Variation in the vitamin D receptor gene is not associated with risk of colorectal cancer in the Czech republic. J Gastrointest Canc 2011; 42: 149-154.

Hunter K, Parkinson E, Harrison P. Profiling early head and neck cancer. Nature Rev 2005; 5: 127-135.

I

Ingles S, Ross R, Yu M, Irvine R, La Pera G, Haile R, Coetzee G. Association of prostate cancer risk with genetic polymorphisms in vitamin D receptor. J Natl Cancer Inst 1997; 89: 166-170.

Ingles S. Can diet and/or sunlight modify the relationship between vitamin D receptor polymorphisms and prostate cancer risk? Nutr Rev 2007; 2: S105S107.

Jemal A, Bray F, Center M, Ferlay J, Ward E, Forman D. Global Cancer Statistics. Cancer J Clin 2011; 61: 69-90.

Jensen S, Madsen M, Lukas J, Binderup L, Bartek J. Inhibitory effects of 1alpha,25dihydroxyvitamin $\mathrm{D}(3)$ on the $\mathrm{G}(1)-\mathrm{S}$ phase-controlling machinery. Mol Endocrinol 2001; 15: 1370-1380.

Jiang F, Bao J, Li P, Nicosia S, Bai W. Induction of ovarian cancer cell apoptosis by $1 \alpha, 25$-dihydroxyvitamin D3 through the down-regulation of telomerase. J Biol Chem 2004; 279: 53213-53221. 
John E, Schwartz G, Koo J, Van Den Berg D, Ingles S. Sun exposure, vitamin D receptor gene polymorphisms and risk of advanced prostate cancer. Cancer Res 2005; 65: 5470-5479.

Johnson N, Warnakulasuriya S, Gupta P, Dimba E, Chindia M, Otoh E, Sankaranarayanan R, Califano J, Kowalski L. Global oral health inequalities in incidence and outcomes for oral cancer: causes and solutions. Adv Dent Res $2011 ; 23: 237-246$.

Jones G, Prosser D, Kaufmann M. 25-Hydroxivitamin D-24-hydroxilase (CYP24A1): Its important role in the degradation of vitamin D. Arch biochem biophys 2012; 523: 9-18.

$\mathbf{K}$

Kemmis C, Salvador S, Smith K, Welsh J. Human mammary epithelial cells express CYP27B1 and are growth inhibited by 25-hydroxyvitamin D-3, the major circulating form of vitamin D-3. J Nutr 2006; 136: 887-892.

Kochupillai N. The physiology of vitamin D: current concepts. Indian J Med Res 2008; 127: 256-262.

Komagata S, Nakayima M, Takagi S, Mohri T, Tniya T, Yokoi T. Human CYP24 catalyzing the inactivation of calcitriol is post-transcriptionally regulated by miR-125b. Mol Pharmacol 2009; 76: 702-709.

Konety B, Lavelle J, Pirtskalaishvili G, Dhir R, Meyers SA, Nguyen T, Hershberger P, Shurin M, Johnson CS, Trump D, Zeidel M, Getzenberg R. Effects of vitamin D (calcitriol) on transitional cell carcinoma of the bladder in vitro and in vivo. $J$ Urol 2001; 165: 253-258. 
Kornfehl J, Formanek M, Temmel A, Knerer B, Willheim M. Antiproliferative effects of the biologically active metabolite of vitamin D3 $\left(1,25[\mathrm{OH}]_{2} \mathrm{D}_{3}\right)$ on head and neck squamous cell carcinoma cell lines. Eur Arch Otorhinolaryngol 1996; 253 : 341-344.

Kostner K, Denzer N, Muller C, Klein R, Tilgen W, Reichrath J. The relevance of vitamin D receptor (VDR) gene polymorphisms for cancer: a review of the literature. Anticancer Res 2009; 29: 3511-3536.

Kruse A, Bredell M, Gratz K. Oral squamous cell carcinoma in non-smoking and non-drinking patients. Head Neck Oncol 2010; 2: 24.

Kupfer S, Anderson J, Ludvik A, Hooker S, Skol A, Kittles R, Keku T, Sandler R, RuizPonte C, Castellvi-Bel S, Casttels A, Carracedo A, Ellis N. Genetic associations in the vitamin $\mathrm{D}$ receptor and colorectal cancer in Afrikan Amerikans and Caucasians. PLoS One 2011; 6: e26123.

$\mathbf{L}$

Lagunova Z, Porojnicu A, Lindberg F, Hexeberg S, Moan J. The dependency of vitamin D status on body mass index, gender, age and season. Anticancer Res 2009; 29: 3713-3720.

Lambert R, Sauvaget C, de Camargo Cancela M, Sankaranarayanan R. Epidemiology of cancer from the oral cavity and oropharynx. Eur J Gastroenter Hepat 2011; 23: 633-641.

Lamprecht S, Lipkin M. Chemoprevention of colon cancer by calcium, vitamin D and folate: molecular mechanisms. Nature Rev 2003; 3: 601-614. 
Li H, Stampfer M, Hollis B, Mucci L, Gaziano M, Hunter D, Giovannucci E, Ma J. A prospective study of plasma vitamin D metabolites, vitamin D receptor polymorphisms and prostate cancer. PLoS Med 2007; 4: e103.

Lin M, Smith L, Smiraglia D, Kazhiyur-Mannar R, Lang J, Schuller D, Kornacker K, Wenger R, Plass C. DNA copy number gains in head and neck squamous cell carcinoma. Oncogene 2006; 24: 1424-1433.

Lin R, White J. The pleiotropic actions of vitamin D. BioEssays 2003; 26: 21-28.

Lindenblatt R, Martinez G, Silva L, Faria P, Camisasca D, Lourenco S. Oral squamous cell carcinoma grading systems-analysis of the best survival predictor. J Oral Pathol Med 2012; 41: 34-39.

Lingen M, Pinto A, Mendes R, Franchini R, Czerninski R, Tilakaratne W, Partridge M, Peterson D, Woo S. Genetics/epigenetics of oral premalignancy: current status and future research. Oral Dis 2011; 17(Suppl. I): 7-22.

Liu Y, Chen W, Hu Z, Xu L, Shu Y, Pan S, Dai J, Jin G, Ma H, Shen H. Plasma vitamin D levels and vitamin D receptor polymorphisms are associated with survival of non-small cell lung cancer. Chin J Cancer Res 2011; 23: 33-37.

Liu Z, Calderon J, Zhang Z, Sturgis E, Spitz M, Wei Q. Polymorphisms of vitamin D receptor gene protect against the risk of head and neck cancer. Pharmacogenet Genomics 2005; 15: 159-165.

Liu, M. Lee, M.-H. Cohen, M. Bommakanti, M. \& L. P. Freedman: Transcriptional activation of the cdk inhibitor p21 by vitamin $D_{3}$ leads to the induced differentiation of the myelomonocytic cell line U937. Gene Dev 1996; 10: 142153. 
Llewellyn C, Linklater K, Bell J, Johnson N, Warnakulasuriya S. An analysis of risk factors for oral cancer in young people: a case-control study. Oral Oncol 2004; 40: 304-313.

Lopez-Boado Y, Puente X, Alvarez S, Tolivia J, Binderup L, Lopez-Otin C. Growth inhibition of human breast cancer cells by 1,25-Dihydroxyvitamin $D_{3}$ is accompanied by induction of apolipoprotein D expression. Cancer Res 1997; 57: 4091-4097.

Lou Y, Qiao S, Talonpoika R, Syvala $H$, Tuohimaa $P$. The role of vitamin $D_{3}$ metabolism in prostate cancer. J Steroid Biochem Mol Biol 2004; 92: 317-325.

Luo W, Karpf A, Deeb K, Muindi J, Morrison C, Johnson C, Trump D. Epigenetic regulation of vitamin D 24-hydroxylase/CYP24A1 in human prostate cancer. Cancer Res 2010; 70: 5953-5962.

Lurie G, Wilkens L, Thompson P, McDuffie K, Carney M, Terada K et al. Vitamin D receptor gene polymorphisms and epithelial ovarian cancer risk. Cancer Epidemiol Biomarkers Prev 2007; 16: 2566-2571.

\section{M}

Macdonald F, Ford C, Casson A. Molecular biology of cancer. Second edition, Garland Science/BIOS Scientific Publishers, 2004: 1-10.

Mahmoudi T, Karimi K, Mohebbi S, Fatemi S, Zali M. Start codon FokI and intron 8 BsmI variants in the vitamin D receptor gene and susceptibility to colorectal cancer. Mol Biol Rep 2011; 38: 4765-4770.

Mantell D, Owens P, Bundred N, Mawer B, Canfield A. 1 alpha, 25dihydroxyvitamin $\mathrm{D}_{3}$ inhibits angiogenesis in vitro and in vivo. Circ Res 2000; 87: 214-220. 
Maruyama R, Aoki F, Toyota M, Sasaki Y, Akashi H, Mita H, Suzuki H, Akino K, OheToyota M, Maruyama Y, Tatsumi H, Imai K, Shinomura Y, Tokino T. Comparative Genome analysis identifies vitamin D receptor gene as a direct target of p53mediated transcriptional activation. Cancer Res 2006; 66: 4574-83.

Mascolo M, Siano M, Ilardi G, Russo D, Merolla F, De Rosa G, Staibano S. Epigenetic disregulation in oral cancer. Int J Mol Sci 2012; 13: 2331-2353.

McCullough M, Bostck R, Mayo T. Vitamin D gene pathway polymorphism and risk of colorectal, breast and prostate cancer. Ann Rev Cancer 2009; 29: 111-132.

McCullough M, Stevens V, Diver W, et al. Vitamin D pathway gene polymorphisms, diet, and risk of postmenopausal breast cancer: a nested case-control study. Breast Cancer Res 2007; 9: R9.

Mikhak B, Hunter D, Spiegelman D, Platz E, Hollis B, Giovannucci E. Vitamin D receptor (VDR) gene polymorphisms and haplotypes, interactions with plasma 25-hydroxyvitamin $\mathrm{D}$ and 1,25-dihydroxyvitamin $\mathrm{D}$ and prostate cancer risk. Prostate 2007; 67: 911-923.

Milner J. Nutrition and cancer: essential elements for a roadmap. Cancer Letters 2008; 269: 189-198.

Mimori K, Tanaka Y, Yoshinaga K, Masuda T, Yamashita K, Okamoto M. Clinical significance of the overexpression of the candidate oncogene CYP24A1 in esophageal cancer. Ann Oncol 2004; 15: 236-241.

Minn A, Gupta G, Siegel P, Bos P, Shu W, Giri D, Viale A, Olshen A, Gerald W, Massagué J. Genes that mediate breast cancer metastasis to lung. Nature 2005; 436: 518-524. 
Mohri T, Nakajima M, Takagi S, Komagata S, Yokoi T. MicroRNA regulates human vitamin D receptor. Int J Cancer 2009; 125: 1328-1333.

$\mathbf{N}$

Nagpal S, Na S, Rathnachalam R. Noncalcemic actions of vitamin D receptor ligands. Endocrine Rev 2005; 26: 662-687.

Nair U, Bartsch H and Nair J Alert for an epidemic of oral cancer due to use of the betel quid substitutes gutkha and pan masala: a review of agents and causative mechanisms Mutagenesis 2004; 19: 251-262.

Nejentsev S, Godfrey L, Snook H, Rance H, Nutland S, Walker N, Lam A, Guja C, Ionescu-Tirgoviste C, Undlien D, Rønningen K, Tuomilehto-Wolf E, Tuomilehto J, Newport M, Clayton D, Todd J. Comparative high-resolution analysis of linkage disequilibrium and tag single nucleotide polymorphisms between populations in the vitamin D receptor gene. Hum Mol Gen 2004; 13: 1633-1639.

Norman A. Minireview: vitamin D receptor: new assigments for an already busy receptor. Endocriniology 2006; 147: 5542-5548.

$\mathbf{0}$

Obara W, Suzuki Y, Kato K, Tanji S, Konda R, Fujioka T. Vitamin D receptor gene polymorphisms are associated with increased risk and progression of renal cell carcinoma in a Japanese population. Int J Urol 2007; 14: 483-487.

Orell-Kotikangas H, Schwab U, Osterlund P, Saarilahti K, Makitie O, Makitie A. High prevalence of vitamin D insufficiency in patients with head and neck cancer at diagnosis. Head Neck 2012; doi: 10.1002/hed.21954. 
Orlov I, Rochel N, Moras D, Klaholz B. Structure of the full human RXR/VDR nuclear receptor heterodimer complex with its DR3 target DNA. EMBO J 2012; 31: 291300.

Osborne J, Hutchinson P. Vitamin D and systemic cancer: is this relevant to malignant melanoma? Br J Dermatol 2002; 147: 197-213.

\section{$\mathbf{P}$}

Palmer H, Gonzalez-Sancho JM, Espada J, Berciano M, Puig I, Baulida J, Quintanilla M, Cano A, García de Herreros A, Lafarga M, Muñoz A. Vitamin $D_{3}$ promotes the differentiation of colon carcinoma cells by the induction of E-cadherin and the inhibition of catenin signaling. J Cell Biol 2001; 154: 369-387.

Parisi E, Rene J, Cardus A, Valcheva P, Pinol-Felis C, Valdivielso J, Fernandez E. Vitamin D receptor levels in colorectal cancer- possible role of BsmI polymorphism. J Steroid Biochem Mol Biol 2008; 11: 87-90.

Pelluchi C, Talamini R, Negri E, Levi F, Conti E, Franceschi S, La Vecchia C. Folate intake and risk of oral and pharyngeal cancer. Ann Oncol 2003; 14: 1677-1681.

Perez-Ordonez B, Beauchemin M, Jordan R. Molecular biology of squamous cell carcinoma of the head and neck. J Clin Pathol 2006; 59: 445-453.

Perez-Sayans M, Somosa-Martin JM, Barros-Angueira F, Reboiras-Lopes MD, Gandara Rey JM, Garcia-Garcia A. Genetic and molecular alterations associated with oral squamous cell carcinoma. Oncol Rep 2009; 22: 1277-1282.

Petersen P. Oral cancer prevention and control- the approach of the World Health Organization. Oral Oncol 2008; 45: 454-460. 
Petti S, Scully C. Oral cancer: The association between nation-based alcoholdrinking profiles and oral cancer mortality. Oral Oncol 2005; 41: 828-834.

Pfister D, Ang K, Brizel D, Burtness B, Cmelak A, Colevas D, Dunphy F, Eisele D, Gilbert J, Gillidon M, Haddad R, Haughey B, Hicks W, Hitchcock Y, Kies M, Lydiatt W, Maghami E, Martins R, McCaffrey T, Mittal B, Pinto H, Ridge J, Samant S, Sanguineti G, Schuller D, Shah J, Spencer S, Trotti A, Weber R, Wolf G, Worden F. Head and neck cancers. J Natl Compr Canc Netw 2011; 9: 596-650.

Povey J, Darakhshan F, Robertson K, Bisset Y, Mekky M, Rees J et al. DNA repair gene polymorphisms and genetic predisposition to cutaneous melanoma. Carcinog 2007; 28: 1087-1093.

Prosser D, Jones G. Enzymes involved in the activation and inactivation of vitamin D. Trends Biochem Sci 2004; 29: 664-673.

$\mathbf{R}$

Ragin CCR, Modugno F, Gollin SM. The epidemiology and risk factors of head and neck cancer: a focus on human papilloma virus. J Dent Res 2007; 86: 104-114.

Raimondi S, Johansson H, Maisonneuve P, Gandini S. Review and meta-analysis on vitamin D receptor polymorphisms and cancer risk. Carcinog 2009; 30: 11701180.

Ramagopalan S, Heger A, Berlanga A, Maugeri N, Lincoln M, Burrell A, Handunnetthi L, Handel A, Disanto G, Orton SM, Watson C, Morahan J, Giovannoni G, Ponting C, Ebers G, Knight J. A ChiP-seq defined genome-wide map of vitamin D receptor binding: associations with disease and evolution. Genome Res 2010; doi:10.1101/gr.107920.110. 
Reichrath J, Kamradt J, Zhu X, Kong X, Tilgen W, Holick M. Analysis of 1,25dihydroxyvitamin $\mathrm{D}_{3}$ receptors (VDR) in basal cell carcinomas. Am J Pathol 1999; 155: 583-589.

Rene Leemans C, Braakhuis B, Brakenhoff R. The molecular biology of head and neck cancer. Nature Cancer Rev 2011; 11: 9-22.

Riggs L. Role of the vitamin D endocrine system in the pathophysiology of postmenopausal osteoporosis. J Cell Biochem 2002; 88: 209-215.

Roff A, Taylor Wilson R. A novel SNP in a vitamin D response element of the CYP24A1 promoter reduces protein binding, transactivation and gene expression. J Steroid Biochem Mol Biol 2008; 112: 47-54.

Ross S. Evidence for the relationship between diet and cancer. Exp Oncol 2010; 32: 137-142.

Ruddon R. Cancer biology. Fourth edition, Oxford University Press 2007.

Rukin N, Strange R. What are the frequency, distribution and functional effects of vitamin D receptor polymorphisms as related to cancer risk? Nutr rev 2007; 65: S96-S101.

$\mathbf{S}$

Schafer A, Emmert S, Kruppa J, Schubert S, Tzvetkov M, Mossner R, Reich K, Berking C, Volkenandt M, Pfohler C, Schon M, Vogt T, Konig I, Reichrath J. No association of vitamin D metabolism-related polymorphisms and melanoma risk as well as melanoma prognosis: a case-control studies. Arch Dermatol Res 2012; 304: 353-361. 
Schulz W. Molecular biology of human cancers: an advanced student's textbook. Springer 2007.

Scully C, Bagan J. Oral squamous cell carcinoma: overview of currentunderstanding of aetiopathogenesis and clinical implications. Oral Dis 2009; 15: 388-399.

Scully C, Bagan J. Recent advances in oral oncology. Oral oncol 2007; 43: 107-115.

Scully C, Field J, Tanzawa H. Genetic aberrations in oral or head and neck squamous cell carcinoma 3: clinico-pathological applications. Oral Oncol 2000; 36: 404-413.

Sharma V, Fretwell D, Crees Z, Kerege A, Klopper J. Thyroid Cancer Resistance to Vitamin D Receptor Activation Is Associated with 24-Hydroxylase Levels But Not the ff FokI Polymorphism. Thyroid 2010; 20: 1103-1111.

Shi H, Yan P, Chen C, Rahmatpanah F, Lofton-Day C, Caldwell C, Huang T. Expressed CpG island sequence tag microarray for dual screening of DNA hypermethylation and gene silencing in cancer cells. Cancer Res 2002; 62: 32143220.

Signorello L, Shi J, Cai Q, Zheng W, Williams S, Long J, Cohen S, Li G, Hollis B, Smith J, Blot W. Common variation in vitamin D pathway genes predicts circulating 25hydroxivitamin D levels among African Americans. PloS One 2011; 6: e28623.

Silverman S. Demographics and occurrence of oral and pharyngeal cancers: the outcomes, the trends, the challenge. J Am Dent Assoc 2001; 132: 7S-11S.

Singh B, Berry J, Vincent L, Lucci A. Involvement of IL-8 and COX-2 mediated bone metastases from breast cancer. J Surg Res 2006; 134: 44-51. 
Slatkin M. Linkage disequilibrium-undrestanding the evolutionary past and mapping the medical future. Nat Rev Genet 2008; 9: 477-485.

Sobin L, Wittekind C. TNM classification of malignant tumours. New York: John Wiley \& Sons, Inc, 2002.

Srinivasan M, Parwani A, Hershberger P, Lenzner D, Weissfeld J. Nuclear vitamin D receptor expression is associated with improved survival in non-small cell lung cancer. J Steroid Biochem Mol Biol 2011; 123: 30-36.

Stewart L, Weigel N. Vitamin D and prostate cancer. Exp Biol Med 2004; 229: 277-284.

Sweeney C, Curtin K, Murtaugh M, Caan B, Potter J, Slattery M. Haplotype analysis of common vitamin D receptor variants and colon and rectal cancers. Cancer Epidemiol Biomarkers Prev 2006; 15: 744-749.

$\check{\mathbf{S}}$

Šupić G, Magić Z. Osnovni epigenetski mehanizmi kancera. Med Data Rev 2009; 4: 31-36.

$\mathbf{T}$

Tamez S, Norizoe1 C, Ochial K, Takahashi D, Shimojima A, Tsutsumi Y et al. Vitamin D receptor polymorphisms and prognosis of patients with epithelial ovarian cancer. Br J Cancer 2009; 101: 1957-1960.

Tayeb M, Clark C, Haites N, Sharp L, Murray G, McLeod H. CYP3A4 and VDR gene polymorphisms and the risk of prostate cancer in men with benign prostate hyperplasia. Br J Cancer 2003; 88: 928-932. 
Taylor A, Hirvonen A, Watson M, Pittman G, Mohler L, Bell A. Association of prostate cancer with vitamin D receptor gene polymorphism. Cancer Res 1996; 56: 4108-4110.

Taylor J, Hirvonen A, Watson M, Pittman G, Mohler J, Bell D. Association of prostate cancer with vitamin D receptor gene polymorhism. Cancer Res 1996; 56: 41084110.

Thorne J, Campbell M. The vitamin D receptor and cancer. Proc Nutr Soc 2008; 67: 115-127.

Trabert B, Malone K, Daling J, Doody D, Bernstein L, Ursin G et al. Vitamin D receptor polymorphisms and breast cancer risk in a large population-based case-control study of Caucasian and African-American women. Breast Cancer Res 2007; 9: R84.

Tregouet D, Garelle V. A new JAVA interface implementation of THESIAS: testing haplotype effects in association studies. Bioinformatics Application Notes 2007; 23: 1038-1039.

Tregouet D, Tiret L. Cox proportional hazards survival regression in haplotypebased association analysis using the stochastic-EM algorithm. Euro J Hum Genet 2004; 12: 971- 974.

Turna A, Pekcolaklar A, Metin M, Yaylim I, Gurses A. The effect of season of operation on the survival of patients with resected non-small cell lung cancer. Interact CardioVasc Thorac Surg 2012; 14: 151-155.

Turunen M, Dunlop T, Carlberg C, Vaisanen S. Selective use of multiple vitamin D response elements underlies the $1 \alpha 25$-dihydroxyvitamin $\mathrm{D}_{3}$-mediated negative regulation of the human CYP27B1 gene. Nucleic Acids Res 2007; 35: 2734-2747. 


\section{$\mathbf{U}$}

Uitterlinden A, Fang Y, van Meurs J, Pols H, van Leeuwen J. Genetics and biology of vitamin D receptor polymorphisms. Gene 2004; 338: 143-156.

\section{V}

Vuolo L, Somma C, Faggiano A, Colao A. Vitamin D and cancer. Front endocrin 2012; 3: doi: 10.3389/fendo.2012.00058.

Vupputuri M, Goswami R, Gupta N et al. Prevalence and functional significance of 25-hydroxyvitamin D deficiency and vitamin D receptor gene polymorphisms in Asian Indians. Am J Clin Nutr 2006; 83: 1411-1419.

W

Wall J, Pritchard J. Haplotype blocks and linkage disequilibrium in the human genome. Nat Rev Genet 2003; 4: 587-597.

Wang Y, Irish J, MacMillan C, Brown D, Xuan Y, Boyington C, Gullane P, Kamel-Reid S. High frequency of microsatellite instability in young patients with head and neck squamous cell carcinoma: lack of involvement of the mismatch repair genes hMLH1 and hMSH2. Int J Cancer 2001; 93: 353-360.

Warnakulasuriya S. Global epidemiology of oral and oropharyngeal cancer. Oral Oncol 2009; 45: 309-316.

Welsh J. Cellular and molecular effects of vitamin D on carncerogenesis. Arch Biochem Biophys 2012; 523: 107-114. 
Whitfield K, Remus L, Jurutka P, Zitzer H, Oza A, Dang H et al. Functionally relevant polymorphisms in the human nuclear vitamin D receptor gene. Mol Cell Endocrinol 2001; 177: 145-159.

Whitlatch L, Young M, Schwartz G, Flanagan J, Burnstein K, Lokeshwar B, Rich E, Holick M, Chen T. 25-Hydroxyvitamin D-1-hydroxylase activity is diminished in human prostate cancer cells and is enhanced by gene transfer. J Steroid Biochem Mol Biol 2002; 81: 135-140.

$\mathbf{X}$

Xu Y, Shibata A, McNeal J, Stamey T, Feldman D, Peehl D. Vitamin D receptor start codon polymorphism (FokI) and prostate cancer progression. Cancer Epidem Biomarkers Prev 2003; 12: 23-27.

$\mathbf{Y}$

Ylikomi T, Laaksi I, Lou Y, Martikainen P, Miettinen S, Pennanen P, Purmonen S, Syvala H, Vienonen A, Tuohimaa P. Antiproliferative action of vitamin D. Vitamins and Hormons 2002; 64: 357-406.

$\mathbf{Z}$

Zaykin D, Westfall P, Young S, Karnoub M, Wagner M, Ehm M. Testing association of statistically inferred haplotypes with discrete and continuous traits in samples of unrelated individuals. Hum Hered 2002; 53: 79-91.

Zeljic K, Supic G, Stamenkovic Radak M, Jovic N, Kozomara R, Magic Z. VDR, CYP27B1 and CYP24A1 genes polymorphisms association with oral cancer risk and survival. J Oral Pathol Med 2012; doi: 10.1111/j.1600-0714.2012.01164.x 
Zhou W, Heist R, Liu G, Asomaning K, Neuberg D, Hollis B, Wain J, Lynch T, Giovannucci E, Su L, Christiani D. Circulating 25-Hydroxyvitamin D Levels Predict Survival in Early-Stage Non-Small-Cell Lung Cancer Patients. J Clin Oncol 2007; 25: 479-485.

Zhou W, Heist R, Liu G, Neuberg D, Asomaning K, Su L, Wain J, Lynch T, Giovannucci E, Christiani D. Polymorphisms of vitamin D receptor and survival in early-stage non-small cell lung cancer patients. Cancer Epidem Biomarkers Prev 2006; 15: 2239-2245.

\section{Web stranice}

www.ncbi.nlm.nih.gov/SNP

www.hapmap.org

www2.cnrs.fr/en/1961.htm

www.drnickcampos.com/health-newsletter/VitD.html

www.ghr.nlm.nih.gov/gene/VDR

www.ncbi.nlm.nih.gov/protein/NP 000776.1

www.bioscience.org/2005/v10/af/1514/ fulltext.asp?bframe=figures.htm\&doi=ye www.ghr.nlm.nih.gov/gene/CYP27B1

www.ghr.nlm.nih.gov/gene/CYP24A1 
8. BIOGRAFIJA AUTORA 
Diplomirani biolog Katarina Zeljić je rođena 04.07.1984. godine u Loznici. Biološki fakultet Univerziteta u Beogradu, studijska grupa Biologija upisala je školske 2003/2004. godine. Diplomirala je 2008. godine na usmerenju Primenjena genetika, sa prosečnom ocenom 9.82. Školske 2008/2009. godine je upisala doktorske studije na Biološkom fakultetu Univerziteta u Beogradu, modul: Genetika. U periodu od 2009-2011. godine je bila stipendista Ministarstva nauke i tehnološkog razvoja Republike Srbije u okviru projekta „Adaptivni značaj genetičkog polimorfizma populacija Drosophila“ (evidencioni broj 143014). Pored pomenutog, Katarina Zeljić je bila nosilac stipendije opštine Loznica (2001-2002.), kao i stipendije Ministarstva nauke i tehnološkog razvoja Republike Srbije za studiranje (2002-2008.). Saradnik je na projektu „Prognostički i prediktivni značaj genetskih i epigenetskih promena u solidnim tumorima“ (evidencioni broj VMA/0610/A1).

Katarina Zeljić je do sada bila autor i koautor 6 naučnih publikacija u vrhunskim časopisima međunarodnog značaja i 10 saopštenja na skupovima međunarodnog značaja iz uže naučne oblasti.

Katarina Zeljić je 2002. godine osvojila prvo mesto na međunarodnoj BIOS olimpijadi (Sankt Petersburg, Rusija), 2007. godine dobila nagradu EFG banke za najbolje studente Srbije u okviru projekta „Investiramo u Evropske vrednosti“, a 2011. godine je dobila stipendiju Union Graduate College-Mount Sinai School of Medicine, za program edukacije Bioetike.

Tokom školske 2009/2010. godine je kao student doktorskih studija učestvovala u izvođenju praktične nastave na Katedri za genetiku i evoluciju. Od februara 2011. godine je zaposlena na Biološkom fakultetu Univerziteta $u$ Beogradu, najpre kao saradnik u nastavi, a potom i kao asistent na Katedri za genetiku i evoluciju. Školske 2011/2012. je bila angažovana kao asistent po pozivu na Medicinskom fakultetu Vojnomedicinske akademije Univerziteta odbrane $u$ Beogradu.

Uža naučna oblast interesovanja su: molekularna genetika i epigenetika kancera, humana populaciona genetika i etika naučno-istraživačkog rada. 


\section{PRILOZI}


Прилог 1.

\section{Изјава о ауторству}

Потписани-а Катарина Зељић

број уписа Б504/2008

\section{Изјављујем}

да је докторска дисертација под насловом

Повезаност полиморфизама VDR, CYP27B1 и CYP24A1 гена са етиолошким факторима и исходом болести код пацијената са оралним сквамоцелуларним карциномом

- резултат сопственог истраживачког рада,

- да предложена дисертација у целини ни у деловима није била предложена за добијање било које дипломе према студијским програмима других високошколских установа,

- да су резултати коректно наведени и

- да нисам кршио/ла ауторска права и користио интелектуалну својину других лица.

\section{Потпис докторанда}

У Београду, 03.10.2012. 
Прилог 2.

\title{
Изјава о истоветности штампане и електронске верзије докторског рада
}

\author{
Име и презиме аутора __ Катарина Зељић \\ Број уписа Б504/2008 \\ Студијски програм Биологија, модул Генетика
}

Наслов рада Повезаност полиморфизама VDR, CYP27B1 и CYP24A1 гена са етиолошким факторима и исходом болести код пацијената са оралним сквамоцелуларним карциномом

Ментор проф. др Марина Стаменковић- Радак, проф. др сци. мед. Звонко Магић

Потписани _Катарина Зељић

изјављујем да је штампана верзија мог докторског рада истоветна електронској верзији коју сам предао/ла за објављивање на порталу Дигиталног репозиторијума Универзитета у Београду.

Дозвољавам да се објаве моји лични подаци везани за добијање академског звања доктора наука, као што су име и презиме, година и место рођења и датум одбране рада.

Ови лични подаци могу се објавити на мрежним страницама дигиталне библиотеке, у електронском каталогу и у публикацијама Универзитета у Београду.

Потпис докторанда

У Београду, 03.10.2012. 


\section{Прилог 3.}

\section{Изјава о коришћењу}

Овлашћујем Универзитетску библиотеку „Светозар Марковић“ да у Дигитални репозиторијум Универзитета у Београду унесе моју докторску дисертацију под насловом:

Повезаност полиморфизама VDR, CYP27B1 и CYP24A1 гена са етиолошким факторима и исходом болести код пацијената са оралним сквамоцелуларним карциномом

која је моје ауторско дело.

Дисертацију са свим прилозима предао/ла сам у електронском формату погодном за трајно архивирање.

Моју докторску дисертацију похрањену у Дигитални репозиторијум Универзитета у Београду могу да користе сви који поштују одредбе садржане у одабраном типу лиценце Креативне заједнице (Creative Commons) за коју сам се одлучио/ла.

1. Ауторство

2. Ауторство - некомерцијално

(3.)Ауторство - некомерцијално - без прераде

4. Ауторство - некомерцијално - делити под истим условима

5. Ауторство - без прераде

6. Ауторство - делити под истим условима

(Молимо да заокружите само једну од шест понуђених лиценци, кратак опис лиценци дат је на полеђини листа).

Потпис докторанда

У Београду, 03.10.2012. 
1. Ауторство - Дозвољавате умножавање, дистрибуцију и јавно саопштавање дела, и прераде, ако се наведе име аутора на начин одређен од стране аутора или даваоца лиценце, чак и у комерцијалне сврхе. Ово је најслободнија од свих лиценци.

2. Ауторство - некомерцијално. Дозвољавате умножавање, дистрибуцију и јавно саопштавање дела, и прераде, ако се наведе име аутора на начин одређен од стране аутора или даваоца лиценце. Ова лиценца не дозвољава комерцијалну употребу дела.

3. Ауторство - некомерцијално - без прераде. Дозвољавате умножавање, дистрибуцију и јавно саопштавање дела, без промена, преобликовања или употребе дела у свом делу, ако се наведе име аутора на начин одређен од стране аутора или даваоца лиценце. Ова лиценца не дозвољава комерцијалну употребу дела. У односу на све остале лиценце, овом лиценцом се ограничава највећи обим права коришћења дела.

4. Ауторство - некомерцијално - делити под истим условима. Дозвољавате умножавање, дистрибуцију и јавно саопштавање дела, и прераде, ако се наведе име аутора на начин одређен од стране аутора или даваоца лиценце и ако се прерада дистрибуира под истом или сличном лиценцом. Ова лиценца не дозвољава комерцијалну употребу дела и прерада.

5. Ауторство - без прераде. Дозвољавате умножавање, дистрибуцију и јавно саопштавање дела, без промена, преобликовања или употребе дела у свом делу, ако се наведе име аутора на начин одређен од стране аутора или даваоца лиценце. Ова лиценца дозвољава комерцијалну употребу дела.

6. Ауторство - делити под истим условима. Дозвољавате умножавање, дистрибуцију и јавно саопштавање дела, и прераде, ако се наведе име аутора на начин одређен од стране аутора или даваоца лиценце и ако се прерада дистрибуира под истом или сличном лиценцом. Ова лиценца дозвољава комерцијалну употребу дела и прерада. Слична је софттерским лиценцама, односно лиценцама отвореног кода. 